\title{
RAWINISQUD:
}

ImL AND Bum togandy

\section{FOR USE IN}

\section{LIBRARY}

ONLY 


RAFINESQUE 

Digitized by the Internet Archive in 2007 with funding from Microsoft Corporation 
PLATE I

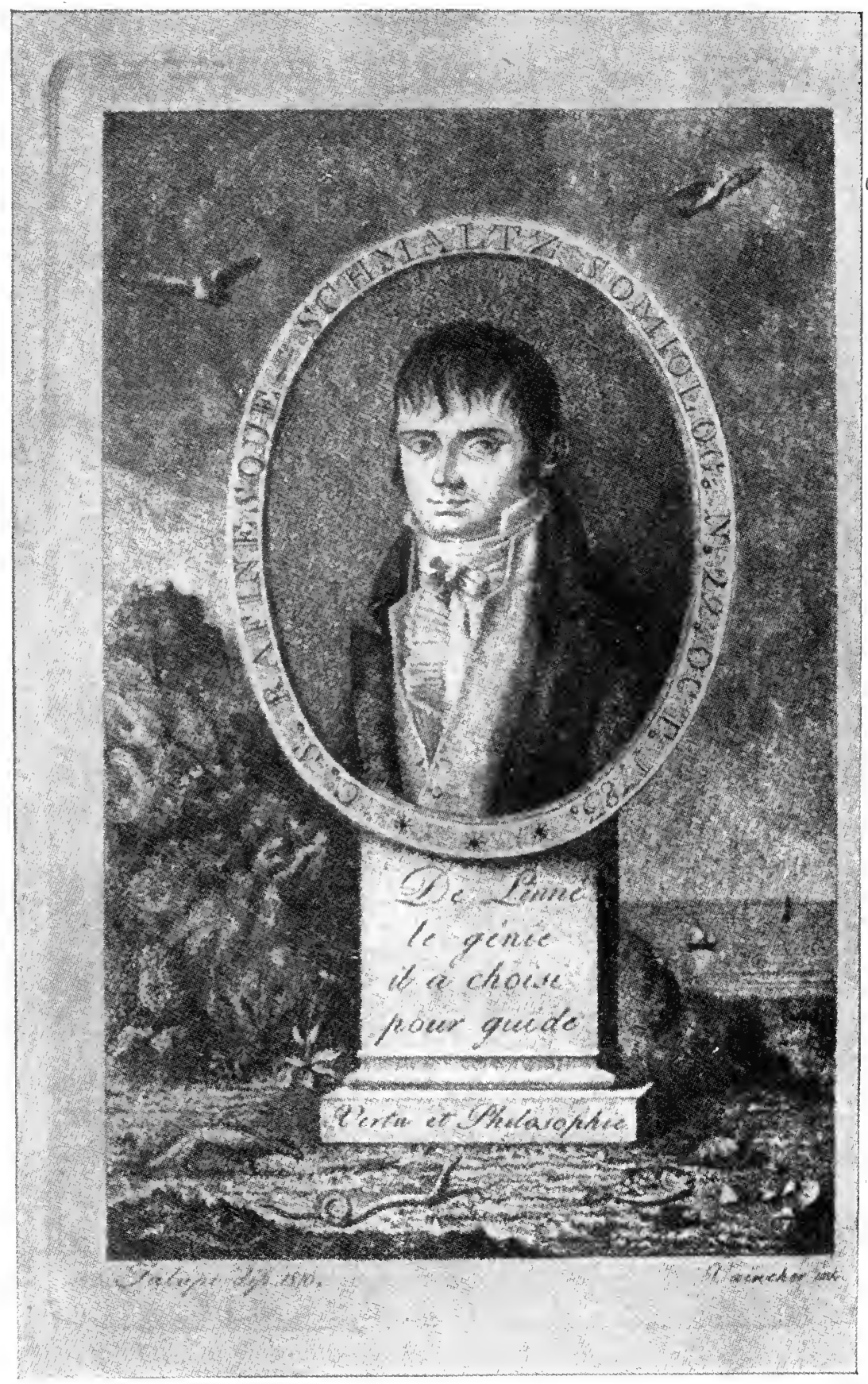

Portrait of C. S. Rafinesque, from the "Analyse de la Nature" 


\title{
RAFINESQUE
}

\section{A SKETCH OF HIS LIFE WITH BIBLIOGRAPHY}

\author{
By T. J. FITZPATRICK, M. S.
}

Fellow of the American Association for the Advancement of Science; Fellow of the Iowa Academy of Science; Member of the Torrey Botanical Club; Member of the American

Historical Association, Etc.

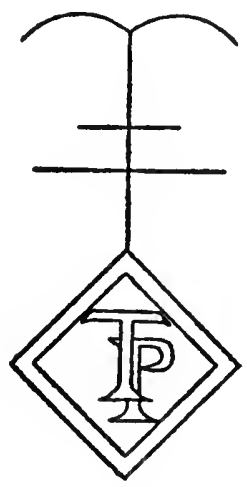

DES MOINES

THE HISTORICAL DEPARTMENT OF IOWA 


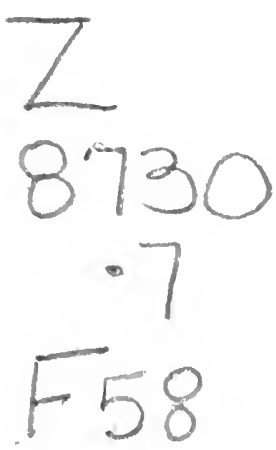

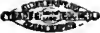

THE TORCH PRESS

CEDAR RAPIDS

$$
\text { IOWA }
$$




\section{FOREWORD}

The inception of this work is to be credited to the late Honorable Charles Aldrich who knew of the writer's interest in the career of Rafinesque and in Rafinesquiana and only to his kindly request and persistent urging is this volume due. 



\section{CONTENTS}

Constantine Samuel Rafinesque - A Sketch . . 11 Bibliography of C. S. Rafinesque . . . . 65 Bibliotheca Rafinesquiana . . . . . . 223

PoRTRAITS OF RAFINESQUE . . . . . . . . 240 

RAFINESQUE-A SKETCH 


\section{CONSTANTINE SAMUEL RAFINESQUE}

\section{A SKETCH}

In a suburb of Constantinople, called Galata, C. S. Rafinesque was born in the year $1783 .{ }^{1}$ His father, G. F. Rafinesque, was a native of Marseilles and of French origin. His mother, Mme. Schmaltz, was born in Greece but of German extraction. Therefore truly it may be said, as has been alleged, that C. S. Rafinesque was a Franco-German by blood and a Turko-Grecian by nativity.

G. F. Rafinesque was a member of the firm of Lafleche $\&$ Rafinesque of Marseilles and had charge of the branch office of the firm established at Constantinople in order to secure trade from the orient. The fact that the mother of Rafinesque was Grecian by birth has given color to the statement that his mother tongue was modern Greek. ${ }^{2}$ French, however, seems to have been his means of communication in early life in spite of the fact that his infant lispings may have been in the Greek vernacular. While still an infant he was taken by his parents to Scutari in Asia and a short time later by sea to Marseilles, stopping on the way at Smyrna and Malta.

Marseilles remained the home of Rafinesque and his mother for several years, although his father returned

\footnotetext{
1 The date given by Haldeman in American Journal of Science, vol. 42, p. 280 , is October 22, 1783. Rafinesque does not give the date in his Lif $\varepsilon$ of Travels, but one could infer from the text that the year was 1784 .

2 Greene, Pittonia, vol. 2, p. 123, 1890; The Cincinnati Literary Gazctte, vol. II, no. 26, p. 203, December 25, 1824.
} 
to the Levant and remained for two years engaged in trade. Our subject states that he first became conscious of his existence "in one of the numerous country seats which surround and beautify the neighbourhood of Marseilles, where they are called Bastides. It was there among the flowers and fruits that I began to enjoy life, and I became a Botanist. Afterwards the first premium $I$ received in a school was a book on Animals, and I am become a Zoologist and Naturalist. My early voyage made me a traveler." ${ }^{3}$

Rafinesque's second and third voyages and the first he afterwards remembered were made with his parents on a trip to Leghorn where his paternal aunt resided. In r79I the father of Rafinesque as part owner of the ship Argonaute started on a voyage to Mauritius and China by way of the Cape of Good Hope. The ship fell among the English cruisers but escaped by crossing over to Philadelphia where ship and cargo were sold. Here the elder Rafinesque sickened with yellow fever and died in I793. Meanwhile, the French revolution being in progress, Mme. Rafinesque took her two sons and one daughter and left for Leghorn, Italy, in order to escape the Reign of Terror. At this place they remained during the years from I792 to I 796 . Here Rafinesque received instruction in the common branches and in the English language from private tutors. He acquired the Italian from his associates. Books on natural history and travel were read with deep interest. In after years he boasted that at the age of twelve he had read the Universal History, an extensive work, and a thousand volumes on a variety of subjects. In I795, at the age of

${ }^{3}$ Rafinesque, Life of Travels, p. 6. 
eleven he began making plant collections. A trip was made to Pisa to see the public games of St. Ranieri, the leaning tower, and other places of interest. In I796 an overland journey was made to Genoa. Rafinesque kept a journal of this trip which he says was his first literary effort of its kind. The journey over the Appenines was made in a sedan chair and by mules while the lumbering coach was chartered for the crossing of the lower country.

After a time spent in Genoa, Rafinesque was sent to Pisa to live with his paternal grandmother. The journey was made partly by sea and partly by land. Rafinesque found time to cultivate his love for botany by collecting plants in the neighborhood of Genoa and of Pisa, along the banks of the Arno, and in the mountains. In I797 his grandmother left Pisa and returned to Marseilles; at the same time she sent her grandson, in charge of a trusty man, back to Genoa. A project was now under advisement to send Rafinesque to a college in Switzerland but unfortunately it was not carried out. He however soon rejoined his grandmother at Marseilles. He continued his education alone by reading with avidity whatever came in his way, preferring, however, books of travel and of the natural sciences. Occasionally incursions were made into the realms of philosophy, chemistry, and medicine. Rafinesque says of this period of his life:

I never was in a regular College, nor lost my time un dead languages; but $I$ spent it in learning alone and by mere reading ten times more than is taught in Schools. I have undertaken to learn the Latin and Greek, as well as the Hebrew, Sanscrit, Chinese and fifty other languages, as I felt the need or inclination to study them.4

Rafinesque was now sixteen years of age and began making plans for the future. He thought of some profession, then again his taste for horticulture suggested

${ }^{4}$ Rafinesque, Life of Travels, pp. 8-9. 
the career of a botanist and a gardener; but apparently family history threw the balance in favor of a business career such as his father had followed. Merchants were more or less peripatetic a century ago and as Rafinesque had acquired a taste for moving about he readily consented to take up the parental choice for a life work. A position of an apprentice-clerk was secured with a distant relative. Meanwhile the woods and the fields about Marseilles gave to him many days of pleasure in the study of the fauna and flora. In a wild romantic place he planted a small flower garden. Days were spent in watching birds and in making sketches of them. The nearby streams and pools contained many fishes as well as shells and crabs. These were studied and some collections gathered. The naturalist, François M. Daudin, resided at Paris and to him Rafinesque sent some of his observations on birds. Daudin was his first learned correspondent. Rafinesque also busied himself collecting books, planning travels, or projecting some literary effort as his boyish fancy suggested. He says :

I had not decided where to travel, many distant countries appeared to invite me; but above all the Grecian and Oriental Regions of my birth, and where resided my maternal relatives. ${ }^{5}$

Meanwhile the troubled state of Europe produced business depression and as a consequence the family fortune was badly depleted and widely scattered. The property of Rafinesque's father and of his uncle, a victim of the revolution, fell into the hands of $\mathrm{Mr}$. Lafleche who fled to Genoa and never made any settlement. At this time, Rafinesque's grandmother died at an advanced age. He was sent back to Leghorn to live with his mother who was now married to a merchant by the name of Lanthois.

${ }^{5}$ Rafinesque, Life of Travels, p. 11. 
This journey he took in company with his brother by the sea route in 1800 . Capture by an English frigate was narrowly averted. Arriving at Genoa, Mr. Lafleche sent them on to Leghorn by sea but at Sestri gaining news of cruisers the remainder of the journey was made overland. The two following years were spent in helping Mr. Lanthois in his commercial transactions and as occasion offered in roaming over the fields and in the woods. $\mathrm{He}$ continued to send observations on birds to Daudin. An English lady by the name of Partridge had a garden and a museum near Montenero to which Rafinesque made frequent visits. A journey was made to Calci in the Appenines of Tuscany, and as the region roundabout appealed to the fancy of Rafinesque he made a topographical map of it.

At eighteen years of age, Rafinesque came to America. Of this interesting voyage he writes:

In 1802 it was resolved to send me with my brother to begin our travels. It was to the United States of America that we were sent, upon several considerations superfluous to state here. This was the period of my real voyages and travels, on the score of importance and novelty, as well as those discoveries which followed my exertions. Before this all my excursions were mere youthful trials in countries well known. I was of course delighted, and eager to begin to see the world. We were provided with an adventure, many letters of introduction, and we departed to roam over the wide world. ${ }^{6}$

In March, I802, Rafinesque and his younger brother, Anthony Augustus, left Leghorn on board the American ship, Philadelphia, owned by the Cliffords, and commanded by Captain Razer, bound for Philadelphia at which city they arrived after a voyage of forty-two days without a single landing. Of this voyage Rafinesque wrote:

We followed the Spanish shore from Cape Gates, and passed the strait

${ }^{6}$ Rafinesque, Life of Travels, pp. 12-13. 
of Gibraltar in a few days. I had the first view of Africa and afterwards of the great Ocean, the famous Atlantic Ocean, which after 4000 years bears yet the name of the first Nations who have crossed it, the Atalas and the Antis! It afforded me a new study of its fishes and mollusca. I drew and described all those that we caught. It was more difficult to procure Birds, but Turtles could be taken while sleeping on the waves. We had a favourable passage, without accidents nor storms. In forty days we obtained the first sight of America, the Capes May and Henlopen forming Delaware Bay. These shores are so low, that the trees are seen before the soil, and give a sylvan impression of this continent. In two days we run up the Bay and River to Philadelphia, where we landed on the 18th April 1802.7

Rafinesque carried letters of introduction to various noted citizens of Philadelphia who received him kindly. The Clifford brothers offered him a position in their counting house; Dr. Benjamin Rush took an interest in the wanderer and offered to become his preceptor. The offer of the Cliffords was accepted but when the yellow fever appeared in the city during the following summer Rafinesque relinquished his position and went to Germantown to live with Colonel Forrest, a horticulturist. Being on a new continent where the productions of nature were very different from those of southern Europe Rafinesque found much for amusement and instruction. In company with Colonel Forrest he made many trips out into the neighboring country and one down into New Jersey through the barrens and along the sea coast. A visit was made in Westchester to Marshall's botanic garden, and Bartram's garden was also visited. The birds, the reptiles, the fishes, and the flowers received attention from Rafinesque. In October after the scourge of yellow fever had passed away Rafinesque returned to his commercial work at Philadelphia. During 1803 he, in company with his brother who had spent the previous year at New York and Newark, returned to Germantown to avoid the dread-

\footnotetext{
${ }^{7}$ Rafinesque, Life of Travels, pp.'13-14.
} 
ed yellow fever. Many excursions were undertaken to neighboring points of interest. A trip was made to Lancaster to visit the noted preacher-botanist, Henry Muhlenburg. Rafinesque became acquainted either by conversation or by correspondence with many of the early American botanists whose reputations give them fame even to this day. The circle included Frederick Pursh, Benjamin Smith Barton, Rev. Henry Muhlenburg, John Bartram, Humphrey Marshall, Titian Peale, Matthias Kin, A. S. Logan, Benjamin Shultz, Gaissen, Jacob Vanvleck, Dr. Joseph Hamilton, Dr. James Mease, Dr. Samuel L. Mitchill, Rev. Manasseh Cutler, Dr. John Brickell, and the French wanderer, Andre Michaux. The majority of these shining lights in the galaxy of early American scientists have left to posterity classic works, the results of intensive studies in their chosen fields.

In the fall of $\mathrm{I} 8 \mathrm{O} 3$ Rafinesque returned to Philadelphia and resigned his position with the Cliffords in favor of his brother and occupied his time during the winter as secretary for Mr. Gernon. As the spring of 1804 came he forsook his occupation and betook himself to the woods. He writes:

My pedestrian excursions of the last year had given me a relish for these rambles; I had become convinced that they were both easy, useful and full of pleasure, while they afforded me the means to study every thing at leasure. I never was happier than when alone in the woods with the blossoms, or resting near a limpid stream or spring, I enjoyed without control the gifts of Flora, and the beauties of nature. I therefore resolved to undertake this year longer journeys before I left America, where I foresaw that I could not remain to advantage, as I often threw my eyes towards Greece and Asia, as another field of exertions and discoveries. ${ }^{8}$

Rafinesque traveled across Delaware from north to south, visiting places of interest, not neglecting to call upon the Governor at his plantation near Dover. The

${ }^{8}$ Rafinesque, Life of Travels, p. 18. 
return trip was along the western shore of Maryland. The Great Dismal Swamp was visited, also Cape Henlopen, the downs, the light house, and the sea shore. The animal and plant life of both sea and land yielded toll to the zealous collector. Observations on soils, strata, and fossils were taken. A visit was made to Washington where he met President Jefferson, Mr. Madison, secretary of state, and other public men. A deputation of Osages were in Washington. They gave their national dances of which Rafinesque was an interested and a surprised spectator. He collected a vocabulary from the chief Pauska or White Head through the interpreter, Mr. Chouteau. The falls of the Potomac, the cities of Alexandria, Baltimore, Havre de Grace, Westchester, Lancaster, Columbia, Harrisburg, the Alleghanies, Reading, New Lebanon, Easton, Bethlehem, Nazareth, and many other places were visited while collecting natural history objects and calling upon citizens of similar predilections.

Rafinesque was now twenty years of age; indeed he was in the formative period of his life. Different forces were exerting their influences and the final results were uncertain. Of this time he writes:

My last excursion this year was a walk to Wilmington in Delaware to visit my friends there. But on my return I received letters from Europe which changed my plans, and induced me to leave America: although then several of my friends wished to detain me, and made me several offers of employment, not quite to my taste. I had once hesitated however when I was told that I might be admitted as Botanist in the expedition which Lewis \& Clark were then preparing to survey the Missouri and cross the Oregon mountains. The dangers of this long journey would not have prevented me to join it; but the difficulty was to be admitted as Botanist or learned Surveyor: it appears that Wilson who wished to join the party as Ornithologist or Hunter, could not obtain the permission. The same might have happened with me; but I did not 
apply: this journey did not promise any reward, while I had the offer of a lucrative situation in Sicily, a country new to me. ${ }^{9}$

Gathering together his worldly possessions Rafinesque accompanied by his brother secured passage late in December on the ship Two Sisters commanded by Captain Evans. Cutting through the ice the ship passed out upon the ocean on New Year's Day, I805, bound for Leghorn. A stormy, and for that day, a swift voyage carried them to their destination. In thirty days the straits of Gibraltar were cleared and in six more the ship was on the shores of Italy. At Leghorn a quarantine of forty days was placed on the ship as Rafinesque says "without cause," but which, however, was not very rigid. His mother and sister as well as friends came frequently to visit him during his detention. He says:

I spent this time of leasure in arranging my plants, drawing the new species, writing my travels and letters. I had brought a fine collection of plants, seeds, shells, minerals, \&c. My herbal contained nearly 2400 species and 10,000 specimens. I sent many to the Professors Savi of Pisa and Radi of Florence, who gave me Italian plants in exchange. ${ }^{10}$

Landing in March, Rafinesque remained in Leghorn and nearby places until into May, when he left on board the Austrian ship, Trabacolo, for Palermo which was reached after a voyage of eight days. Here a quarantine of twenty days was imposed "because there had been yellow fever in Leghorn one year before!"

On landing at Palermo Rafinesque entered the employ of Mr. A. Gibbs, the U. S. consul, as secretary and chancellor. He remained with him until I808, living in his palace. Having saved his earnings, he secured a house and engaged in mercantile pursuits with much profit. Squills and medicinal drugs among other things engaged

${ }^{9}$ Rafinesque, Life of Travels, p. 24.

10 Ibid, p. 26. 
his attention in a commercial way. Excursions were made into all the surrounding territory in quest of animate and inanimate objects for purposes of study and of exchange. The fishes of the sea and other sea life attracted his attention. The mines, the quarries, and Mount Etna received the homage of the enthusiastic student, even the ruins of antiquity scattered over the island excited his wonder and admiration. The English botanist and naturalist, William Swainson, visited $\mathrm{Pa}$ lermo and became the friend and companion of Rafinesque in many a ramble. At about this time Rafinesque was a candidate for the chair of botany in the university, and later the chair of agriculture and economy, but was unsuccessful in both attempts. He continued his studies with unabated zeal, collecting, arranging his specimens, preparing plates for prospective publications, writing for journals, and publishing. Ten years were thus spent on the Island of Sicily, years of toil and of hopeful promise, years upon which Rafinesque afterwards reflected and wrote with a subdued longing:

My first impressions of this lovely Island were delightful: arriving in the month of May, the air was embalmed by the emanations of orange blossoms, carried far at sea in the night by the land breeze. The mountains were smiling with flowers and verdure, they invited me to climb over them. The view of Palermo and the bay is very fine, although not quite equal to that of Naples with the smoking Vesuvius. Here I was then, in Sicily the largest and finest of the Islands in the Mediterranean: a residence of ten years made me perfectly acquainted with it and its natural productions. Few learned travellers can boast to have so long studied Nature in that lovely spot. It was the best epoch of my life. The events of those ten years might afford materials for a romance. ${ }^{11}$

Rafinesque's opinion of Sicily as he tersely gives it is:

Sicily might be described in a few words by saying that she offers . . . a fruitful soil, delightful climate, excellent productions,

\footnotetext{
${ }^{11}$ Rafinesque, Life of Travels, p. 27.
} 
perfidious men, deceitful women . . . such is the outline of her picture. ${ }^{12}$

Growing tired of Sicily and its people Rafinesque began to think of other climes. He proposed to Banks an exploring tour of the coast of Australia but his plan failed to meet with favor. He thought of going to Paris where his mother lived but was prevented from fear of the turbulent condition of the country. Mr. Gibbs was sending a ship to New York which circumstance induced Rafinesque to secure passage again to America. Getting together a quantity of drugs and merchandise for trade along with fifty boxes of personal goods, such as a naturalist possesses, Rafinesque resolutely set out for America where as the sequel shows he was destined to pass the remainder of his life. The story of the voyage as given by him is as follows:

This voyage from Palermo to New York was long and unfortunate: our ship did not sail fast, and we were over 100 days on the way, including our stay in Gibraltar and the Azores. We sailed at the end of July, and only reached Gibraltar in 15 days, after having sailed along Sicily and Sardinia, gone near Bona in Africa on a tack, and followed the Spanish shores from Cape Gates to Malaga and the strait. We often came close to several towns and the island Alboran, in our tacks. At last we entered the strait with a good easterly wind, which might have sent us 600 miles forward in three days, and spared perhaps our mishaps; but we spent these three days of fair wind in Gibraltar, where the Ship was to stop on some business. However this allowed me to land in Spain, to visit the famous mt. Calpe and to herborize on it. Reaching the ocean, we had for awhile favourable weather with many calms, that allowed me to study again the fishes and molusca, to catch turtles, \&c. But arrived near the Azores, we fell into one of those dreadful squalls frequent there. We nearly perished in it, a Brig in sight disappeared, our Ship was thrown on the beams ends, and merely escaped and righted by losing two masts; but thus dismasted we had to seek a harbor in the Id. of St. Michael. Skirting the S. side we reached Punta Delgado the metropolis, where we were well received by the British and American Consuls. * * Having quickly repaired our damage as well as we could, we resumed our voyage; but were nearly two months on the way, being baffled by violent storms,

12 Rafinesque, Life of Travels, p. 27. 
in one we had to throw our guns overboard. We had also to contend against the gulf stream which our Maltese sailors did not know, and crossed improperly. Thus when we reached soundings we were nearly out of provisions. But here a greater misfortune awaited us. The first land in sight was Cape Montauk at the end of Long Id. Westerly winds baffling us yet, we resolved to go to Newport for food and water. We were near it having taken a pilot in the way, when a sudden $\mathrm{N}$. E. wind repulsed us, and being favourable for New York, we turned back towards it through the sound. It was the $2 \mathrm{~d}$ November 1815 , a dreadful day for me. The weather was foggy, at 10 o'clock at night we ran unaware upon the Race rocks, which lay under water between Fisher Id. and Long Id. The wind and tide made us pass over, but we lost our keel. Our Ship filled fast and settled down on one side; but without sinking, being made buoyant by the air of the hold. We had merely the time to escape in our boats, with some difficulty; the long boat was too heavy to be hoisted, but floated as the Ship fell, entangled in the rigging for awhile. Having left the wreck we rowed towards the light house of New London then in sight, and reached it at midnight: thus landing in America for a second time, but in a deplorable situation. I had lost every thing, my fortune, my share of the cargo, my collections and labors for 20 years past, my books, my manuscripts, my drawings, even my clothes . . . . all that I possessed, except some scattered funds, and the Insurance ordered in England for one-third of the value of my goods. For some days after I was in a state of utter dispair. I walked to New London in Connecticut. I was flattered with the hope that the floating Ship could yet be saved; but as soon as the masts were cut to tow it easier, it righted and sunk, after throwing up the confined air of the hold by an explosion. Some hearts of stone have since dared to doubt of these facts or rejoice at my losses! Yes, I have found men, vile enough to laugh without shame at my misfortune, instead of condoling with me! But I have met also with friends who have deplored my loss, and helped me in need.13

Within a short time Rafinesque went overland to New York, and looked about in search of employment. Dr. Samuel L. Mitchill, the editor of the Medical Repository with whom Rafinesque corresponded while residing in Sicily, took an interest in the efforts of the stranger and introduced him among his friends and associates. Meeting with $\mathrm{Mr}$. Livingston he arranged to pass the winter at his country residence as a private tutor for his three daughters. This country residence was near Clermont

${ }^{13}$ Rafinesque, Life of Travels, pp. 46-49. 
on the Hudson river, a hundred miles north of New York. Thither Rafinesque journeyed by stage in December and entered upon his duties. His leisure was spent in reading the books in Mr. Livingston's library, sketching the beautiful scenery, and writing his travels and recollections. In midwinter, Mrs. Livingston's health failing, the family removed to Charleston, S. C. Rafinesque not desiring to go to the south returned to New York and shortly after went to Philadelphia to call upon his former friends.

As spring returned Rafinesque began field work in the natural sciences. His friend Zaccheus Collins lent encouragement by precept and by example. Soon returning by a new route to New York he joined Dr. Samuel L. Mitchill and Captain Alden Partridge in a collecting trip to New Jersey. The mania for roaming was now in full control. A journey was made to Albany in a steamboat. Trips were made out to various points, to the four falls, to Lake George, and the mineral springs at Saratoga, even visiting Ticonderoga in Vermont. These trips enabled Rafinesque to explore and map most of the course of the Hudson river. He was greatly pleased with his tour and returned to New York laden with plants, shells, fossils, and minerals. Long Island and New Jersey were now visited. The insurance on the goods lost in the shipwreck having been received Rafinesque started again in business but the bankruptcy of a New York house and the rascality of a Sicilian caused losses and prevented him from reaping the rewards of his industry. During a business trip to Philadelphia Rafinesque met his former friend, John D. Clifford, who now resided at Lexington, Kentucky, and it was arranged that Rafinesque should go to Kentucky in the spring of $18 \mathrm{I} 8$. 
Rafinesque made an effort to secure an appointment to a professorship in the University of Pennsylvania. The minutes of the trustees' meeting for February 6,1816 , states that Dr. William P. C. Barton and Rafinesque offered themselves as candidates for the professorship of natural history and botany. In the following December Doctor Barton received the coveted preferment. ${ }^{14}$

Meanwhile he had helped to found the Lyceum of Natural History of New York and had become a member of the Philosophical Society. Contributions were made to the American Monthly Magazine and Critical Review. A Flora of Louisiana was published and many literary schemes were projected. During I8I7 two collecting trips were made to various New York stations, one in company with Doctors John Torrey and D'Jurco V. Knevels, and two trips to various places on Long Island. Rafinesque made his home during the summer in Brooklyn but during the winter he resided in New York.

In May, I8I8, Rafinesque set out for the west. The journey to Philadelphia and Lancaster was made by stage. From Lancaster he walked over the Alleghanies through Columbia, York, Chambersburg, Bedford, Greensburg, and on to Pittsburg where he visited awhile, and contracted with Cramer \& Spear, booksellers, to publish a proposed map of the river Ohio and his travels in America.

At Pittsburg Rafinesque fell in with a company of gentlemen and together they purchased an ark with which they floated down the Ohio, camping at night along the shore. On reaching Cincinnati, Rafinesque went overland to Northbend and visited with Mr. Short, a fellow

14 Thorpe, Benjamin Franklin and the University of Pennsylvania, pp. 328-329. 
student of nature. As the ark came by, the journey was resumed to Louisville, where former friends, the Messrs. Tarascon resided. Here two weeks were spent visiting, in studying the fishes and shells at the falls of the Ohio river, and in drawing the striking objects on the spot. "I was surprised," said Rafinesque, "to find them nearly all new." " ${ }^{15}$ After seeing the neighborhood of Louisville passage was taken on a day boat to Hendersonville where some days were pleasantly spent with the famous Audubon. Securing a horse a journey was made to the communistic settlement at New Harmony on the Wabash where a visit was made with Doctor Miller. Crossing the Wabash the journey was continued through Illinois to Shawaneetown and on to the mouth of the Ohio river, the return being made back to Hendersonville through Morgantown. From here Rafinesque walked to Louisville, crossing the barrens and meadows of Kentucky. Visiting with the Messrs. Tarascon for a few days and shipping his collections to Pittsburg, Rafinesque then went to Middleton to call upon his friend, John Bradbury, thence to Lexington to see his friend of former days, John D. Clifford. Of this visit he writes:

The fine museum of fossils and antiquities already collected by Clifford deserved all my attention, I spent many days in studying them and drawing the rarest. He wanted to increase it and he induced me to come and settle with him in Lexington, promising to procure me a Professorship in the University and to travel every year with me in the vacations to increase his museum and my collections. This project which allowed me to travel and explore all the vast regions of the Mississipi

15 Rafinesque, Life of Travels, p. 55.

In a letter to Samuel L. Mitchill, dated at Louisville, Falls of Ohio, 20th July, 1818, Rafinesque states: "I have the pleasure to acquaint you that my discoveries during my journey through the western states, have exceeded my most sanguine expectations, particularly in conchology and ichthyology. . . . I am yet in hopes to increase them." - American Monthly Magazine, vol. 3, p. 354. 
with a friend, and to settle in a healthy and pleasant town, met my approbation. But I had to return to Philadelphia to settle my concerns, and withdraw from trade. ${ }^{16}$

The return to Philadelphia began with a wagon which was soon abandoned. At Maysville Rafinesque crossed the Ohio river and traveled on foot across the state of Ohio, passing through Chillicothe, Lancaster, Zanesville, and Steubenville. Of Ohio Rafinesque states:

It was near Chilicothe that I saw the first great monuments and pyra. mids or altars, of the ancient nations of N. America; they struck me with astonishment and induced me to study them. ${ }^{17}$

Rafinesque crossed the Ohio river at Steubenville and took the Virginia road through the hills to Pittsburg, thence on over the Alleghanies for the second time, noting the geology of the country by the way. A stop was made to visit the mineral springs at Bedford. At Lancaster the stage was taken to Philadelphia.

The winter of 1818 and 1819 was spent in drafting a map of the region of the Ohio river, in preparing papers, and making arrangements to emigrate to the west. Of this period our subject writes:

A friend of mine Mr. Michel wanted then to form a partnership with me in trade; but I gave up trade for Clifford and the west. I even refused the chair of Professor of Chemistry which he could have obtained for me, altho' many Professors of it are less Chemists than I, because I had a greater taste for botany, zoology and geology. Yet one was lucrative, while that which I chose was less so. I obtained thus the Professorship of botany and natural history, with the addition of modern languages, with lodgings, boarding and casual emoluments. ${ }^{18}$

Rafinesque packed his library and collections and shipped them to Lexington, Ky., in care of Clifford. In May, I8I9, he went by steamboat to Baltimore where a visit was made with the botanist, Dr. H. Hayden. Turn-

${ }^{16}$ Rafinesque, Life of Travels, p. 57.

17 Ibid, p. 58.

18 Ibid, p. 59. 
ing now towards the west Rafinesque crossed the Alleghanies for the third time on foot. The itinerary was from Frederick to the Catocton mountains, through the gap of the Potomac river, on to Harper's Ferry, along the river to Cumberland, thence over the table-land through Brownsville to Pittsburg. Here Rafinesque delivered his map of the Ohio river to the booksellers, Messrs. Cramer \& Spear, and received one hundred dollars for his services.

The journey was resumed by taking passage on a keel boat down the Ohio river. A stop was made at Marietta, Ohio, to study and survey the prehistoric remains. While the boat was running the rapids at Letart, Rafinesque crossed the isthmus in West Virginia on foot, collecting along the way, and later meeting the boat at Parkersburg. Arriving at Maysville Rafinesque left the boat and started overland for Lexington, Ky. The route passed over by him by stage and by private carriage is practically the same as is now followed by the railway from Maysville to Lexington.

It was midsummer of I8I9 when Rafinesque reached Lexington. The university was closed for the summer vacation. Clifford was in the hill country to the southward passing the time in search of health, and thither Rafinesque went to meet his friend. There they remained until the close of the season enjoying themselves in communion with nature. As fall approached both returned to Lexington. On the opening of the university Rafinesque began a course of lectures on natural history. In the spring of 1820 a course was given on botany. On the conclusion of the year's work Rafinesque and Clifford were preparing for a journey into western Kentucky and into Arkansas. On the eve of their departure Clifford 
sickened and died a few days later. Rafinesque thus speaks of his misfortune:

This loss of an intimate and zealous friend was blasting to all my hopes and views. I ought to have left the country directly; but finding myself with all my books and collections in a fine unexplored country, where there was much to glean, . . . I thought that I ought to explore it by myself. But instead of traveling in a carriage with Clifford, I had to return to my pedestrian excursions. Horses were offered to me; but I never liked riding them, and dismounting for every flower: horses do not suit botanists. ${ }^{19}$

The summer of 1820 was passed in Kentucky in the immediate neighborhood of Lexington, exploring the ancient remains or collecting objects of natural history. Much time was spent preparing papers for publication. During the school year of I820-I82I lectures on botany were delivered to many students and instruction given to large classes in the French, Italian, and Spanish languages. Many friends were acquired but Rafinesque felt that not one was a Clifford to him. Frequent trips were made to Ashland to visit the statesman Henry Clay, also to a country seat near Harrodsburg where dwelt the genial spirit, Mr. Meade. Dr. C. W. Short, the botanist, and the traveler, John Bradbury, called upon Rafinesque. These gentlemen were old correspondents of his and had sent him objects of natural history. Bradbury's visit was in 1822 .

The chair of materia medica being vacant Rafinesque became a candidate but was not preferred. Times were dull and money scarce. Of these times the following account is given:

The paper money introduced in Kentucky in spite of the Constitution, and which soon fell to 50 per cent, became another cause of displeasure, doubling all my expences, postages, carriage of goods, \&c., preventing me to travel out of Kentucky where it had its only value, and increasing the price of every thing, without increasing my emoluments. My travels were

${ }^{19}$ Rafinesque, Life of Travels, p. 61. 
prepared for the press; but the booksellers of Pittsburg would not print them, in spite of their special contract, owing to the general distress, and I could not go to Pittsburg to compel them. All this combined to disgust me, and I could not travel far this year. I had to confine myself to the villages near Lexington. ${ }^{20}$

A situation in Pulaski college was open to Rafinesque but was refused as he did not wish to go farther inland with his possessions and had resolved to establish a botanic garden or leave Kentucky. The vacation season of 1823 was spent in exploring that state; our subject starting out in May for a two months journey to the Tennessee river and to points in western Kentucky. A visit was made at Bowling Green with General Covington, also at Elkton with Mr. New, with the Shakers at West Union, and at Russelville, thence to Hopkinsville where visits were made with Mr. Campbell and Doctor Short. An excursion was taken to Clarksville on the Cumberland river in Tennessee. A trip to the prehistoric remains at Canton on the Cumberland river was made and across on to the Tennessee river. The country between the Tennessee and Mississippi rivers being unsettled, Rafinesque regretfully turned back although he desired to go on to the great river. The return was through Hopkinsville and Russelville to West Union and Bowling Green, visiting by the way the Cameleon spring; and later the famous Mammoth Cave. Of it Rafinesque wrote: "I spent one day to survey it, and found it very different from the printed exaggerated accounts, but yet wonderful enough." ${ }^{21}$

The return to Lexington occurred in July with ample collections brought in wagons. A short rest and then Rafinesque was away to spend August and September in southeastern Kentucky, going through Danville, Shelby,

${ }^{20}$ Rafinesque, Life of Travels, pp. 65-66.

21 Ibid, p. 70. 
Somerset, to the falls of the Cumberland river, later to Barboursville and the gap of the Cumberland, the return home being by way of Hazlepatch, Mt. Vernon, Crab Orchard, and Stanford, with the usual load of collections.

During the school year of I823-4 Rafinesque gave lectures to the medical students on medical botany, using the modern method of teaching by the exhibition of specimens.

Rafinesque in 1824 went to Frankfort and solicited the legislature for aid to establish a botanic garden at Lexington. The Senate granted the request but the House refused. However, a company was formed and incorporated and subscriptions taken. W. H. Richardson was president of the board of directors and Rafinesque, secretary. The company started out well, secured a desirable plot of ten acres, issued a prospectus containing the bylaws and charter and a booklet of twenty-four pages in English and French, ${ }^{22}$ then languished and died. Rafinesque claimed that in order to divert him from the garden he was appointed librarian of the university and keeper of the museum. Among other calamities he took a bad case of measles. He refused to be medicated and stated that he "recovered in spite of the Physicians, by taking none of their poisons, antimony and opium, while many died in their hands." ${ }^{22 a}$

Rafinesque's travels during I824 were mostly for the purpose of soliciting subscriptions for the establishment of the botanic garden and were made through the country within forty miles around Lexington. A few trips were made to prehistoric sites to study and survey.

${ }^{22}$ See Bibliography, nos. 468 and 469.

22a Life of Travels, p. 72. 


\section{The work for I825 began as follows:}

In March 1825 I began to plant the garden, of which I was the Superintendant; but I soon became aware of a secret hostility to my undertaking, and several subscribers did not pay their installments. It became impossible to struggle against the influence of the foes of sciences. I became weary of it, and resolved to end these perpetual difficulties, by seeking else. where other resources or advantages, undertaking in that view a journey to Washington City, Baltimore and Philadelphia. I left the garden in the hands of Mr. Ficklin, and Lexington at the end of June after the visit of Lafayette. ${ }^{23}$

\section{Of the garden Rafinesque wrote:}

I never owned an acre of ground, this garden would have been my delight: I had traced the plan of it, with a retreat among the flowers, a Green house, Museum and Library; but I had to forsake it at last, and make again my garden of the woods and mountains. ${ }^{24}$

At the close of June, 1825, Rafinesque left for Washington. The stage was taken to Maysville, Chillicothe, Zanesville, and Wheeling. From Wheeling the trip over the Alleghanies was undertaken as usual on foot. At Winchester he visited with Mr. Barton, a fellow student of nature. Taking the stage from thence to the Shenandoah river, then on foot over the Catocton or Blue Mountains to Aldie, thence to Georgetown and Washington. Rafinesque remained a month in Washington visiting with old friends, Major John Adlum and Mr. Winn. He also met the botanists Mr. M'William and John Brereton and was introduced to President Adams. He states that he "induced Maj. M'Kinney at the head of the Indian department, to print circulars to collect vocabularies of 100 words, in all the Languages spoken by the Indians of the United States." 25

Some time was spent visiting the vineyard of Adlum

${ }^{23}$ Rafinesque, Life of Travels, p. 75.

24 Ibid, p. 72.

${ }^{25}$ Rafinesque, Life of Travels, p. 76. The Major's name should have been spelled "M'Kenney." 
who was a successful wine producer. From studies made at this vineyard came in later years the "American Manual of Grape Vines and the Art of Making Wine," which was published in I830.

For some time Rafinesque had devoted his energies to devising various schemes. One of these he called the "Divitial Invention," but it is now known as the "Coupon System." He always claimed to be the inventor of this now widely used system of divisible commercial paper or certificates, and his chief business at Washington was to obtain patents on his various inventions, this one among them. ${ }^{26}$ Henry Clay, of Kentucky, being out of the city at the time, delay occurred, but the business was finally concluded. On leaving the Capital the stage was taken to Baltimore where Dr. James Smith became his host. At Baltimore Rafinesque published his plan of divisible certificates. The plan was soon adopted in part or by improvement, but no returns ever came to the inventor, who shunned lawsuits as a plague and allowed the pirating to go on.

After some time Rafinesque took the steamboat for Philadelphia where he met several of his old friends, among them Zaccheus Collins. It was now well into October and Rafinesque while desiring to go to New York and Boston felt impelled to return to Lexington to close up his affairs preparatory to leaving the west. The stage was taken to Lancaster, Harrisburg, Carlisle, and Chambersburg to the base of the mountains. For the

${ }^{26}$ The writer finds in Document No. 22-House of Representatives State Department-Letter from the Secretary of State transmitting a list of the names of the persons to whom patents have been issued - that $\mathrm{H}$. Clay lists that on "Aug. 23, 1825-Improvement in the mode of making divitials and preventing forgery - Constan'e Sam'l Rafinesque - Lexington, Kentucky." 
fifth time the Alleghanies were crossed on foot, this time by a new route through Berlin, Somerset, and Washington to Wheeling. From Wheeling the route across Ohio was by stage through Zanesville, Lancaster, Circleville, Washington, and Wilmington to Lebanon. The ancient monuments at Circleville were visited. From Lebanon the journey was resumed to Cincinnati where public lectures were given in the museum of Mr. Joseph Dorfeuille. A visit was made to General Taylor and also to Mr. John Cleves Symmes, notorious for his system of concentric spheres and polar openings, who resided in the nearby village of Newport, Kentucky. Shortly afterwards Rafinesque returned to Lexington. How he found matters may be best stated in his own words:

I returned to Lexington by the Ridge road, and proceeded to Frankford, when I found how the President of the University had behaved in my absence. To evince his hatred against sciences and discoveries, he had broken open my rooms, given one to the students, and thrown all my effects, books and collections in a heap in the other. He had also deprived me of my situation as Librarian and my board in the College. I had to put up with all this to avoid beginning law suits. I took lodgings in town and carried there all my effects: thus leaving the College with curses on it and Holly; who were both reached by them soon after, since he died next year at sea of the Yellow fever, caught at New Orleans, having been driven from Lexington by public opinion: and the College has been burnt in 1828 with all its contents. But Clifford's cabinet was saved (like mine) by being removed previously like mine, and is now partly in Cincinnati and partly in Philadelphia. This was a lucky escape. However I never was deprived of my Professorship and have never resigned it! but in the Winter of 1825-26 I gave my last course of lectures on medical Botany. I published my Neogenyton and other pamphlets. I left the botanic garden to its fate, since the company would not support it properly, and thus it has been destroyed. I had some intention to join $\mathrm{Mr}$. Maclure at New Harmony, but he had friends jealous of me also: it was well for me, since his views and fine College have been abortive. ${ }^{27}$

Rafinesque's view of President Horace Holley may be a little severe. However, Holley was a learned man of

${ }^{27}$ Rafinesque, Life of Travels, pp. 78-79. 
the ultra-conservative school and looked askance at anything of scientific tendency. He no doubt considered collections as mere rubbish, the removal of which was a good riddance. He was not of a mind to appreciate scientific merit and probably gave no thought to the fact that his university had in Rafinesque one of the most eminent scientists in America. President Holley guided the destinies of Transylvania University from November, I8I8, to March, I827, which period is considered the most brilliant in the university's career. By indiscreet words and improper conduct Holley created much public opposition, which, fanned by prejudice and religious bigotry, made his position untenable and forced his resignation. Though considerable credit belongs to his predecessor whose wise administration had created favorable conditions and though during his incumbency there were internal dissensions, withal he accomplished much. Into such an atmosphere Rafinesque came, stayed nearly seven years, and left of his own accord. The wonder is that one possessing his sensitive nature should have stayed so long.

Gathering up his books and collections Rafinesque shipped them to Philadelphia. His personal possessions filled forty boxes, according to his account, and had doubled during his residence in Kentucky. After calling upon his friends to bid them adieu, Rafinesque in the year I 826 left Lexington, going by stage to Cincinnati where a public lecture was given. The stage was taken northward to Hamilton, along the Miami river to Dayton, where the ancient remains were studied and observations made of the canal then digging, thence to Springfield. From here Rafinesque walked over to Yellow Springs to visit the community established by Lownes. After the 
visit Lownes sent the traveler back to Springfield in his carriage. At Springfield Rafinesque took the stage to Columbus where one day was spent. The journey was resumed to Mt. Vernon to visit the hills. Rafinesque walked over the hill country through Belleville, Mansfield, and to New Haven, where the stage was taken through Milan to Sandusky on Lake Erie. After waiting three days a steamboat from Detroit came by and passage was secured to Buffalo. Stops were made along the way at Cleveland, Fairport, Erie, and other places.

At Buffalo Rafinesque observed many Seneca Indians. Crossing the Niagara river at Blackrock into Canada gave him opportunity to examine the river and falls from both sides. This phenomenon excited his wonder and admiration. One day was spent on each side studying the botany and geology and making maps and views. The stage was taken to Queenstown. After crossing the river to Lewistown and Manchester the stage was resumed to Lockport, stopping on the way at Tuscarora to visit for a day with David Cusick, the historian of the Iroquois. From Lockport the journey to Rochester was made on the canal in a packet. Here Rafinesque by chance met Professor Amos Eaton, of Troy, who was out on a scientific tour with his pupils on the canal, in a boat of their own and were returning from Buffalo. Being invited to join the company he accepted with pleasure. He afterwards said "it was one of the most agreeable journeys I ever performed." By easy stages the journey to Troy was continued, many side trips being made to points of interest. At Troy rest was obtained for some days at the home of Professor Eaton. The steamboat was then taken to West Point where Dr. John Torrey received the traveler. Later the journey was continued to New York 
and Philadelphia. The remainder of the summer was spent in visiting Dr. Samuel Betton and Reuben Haines at Germantown and in numerous excursions to outlying stations.

In September Rafinesque settled in Philadelphia, devoting the winter of 1826 and I 827 to the giving of a course of lectures on natural history to a class in the Franklin Institute. During the year I 827 he became professor of geography and drawing in the high school of the same institution.

These occupations, Rafinesque states, consumed all his time and his collections were left in store and part of them under a mortgage. The transportation charges from Lexington proved to be very expensive. The vacation of 1827 was spent in research work in the libraries of Philadelphia and of the New England cities. In August a journey was undertaken to Boston, going by way of New York and Troy, where Professor Eaton was again visited. The stage was taken from Troy to Boston, the journey occupying two days. Harvard College was holding commencement on the day after Rafinesque arrived and he was an attendant on this occasion. A week was spent looking through the libraries of Cambridge and Boston and in meeting with learned men. The return to Troy was by way of Worcester where the library of the Antiquarian Society was visited. Various stops were made, but one, especially noteworthy, was at the Shaker settlement of New Lebanon on a visit with the botanist and gardener, Mr. Lawrence. Continuing on to Troy and Albany, the steamboat was there taken to New York. After a brief rest the journey was resumed to Philadelphia, which city was reached in September.

Rafinesque, finding his health poor, abandoned teach- 
ing and looked about for health and enjoyment in study. A volume of his Medical Flora was issued in $\mathrm{I} 828$ and a second in 1830 . Having, as he thought, cured himself of a chronic complaint, he devoted much time and attention to the ills of others, choosing as a specialty the diseases of the lungs. A number of vegetable remedies were prepared and placed on the market and success from a commercial point of view rewarded his efforts. A small book called the Pulmist, or the Art to Cure the Consumption was issued and distributed in I829. It is the common way to severely condemn Rafinesque for this episode in his career, yet after all is said it is difficult for an unprejudiced mind to enter anything more than a general censure. One would be rash to assert that his remedies or methods were any less medicinal than many others regarded as efficacious and ethical at this period or for that matter at the present time. Doubtless they were in many ways superior to some of the methods or remedies then in vogue.

Having noticed in others the tendency to appropriate the discoveries whenever any patents were obtained Rafinesque determined not to secure any more of them. He remarks, "Some envious hearts may have blamed me for it." But he naively adds "they are probably those who would have been the first to steal them if published."

In 1828 the Alleghanies were again visited, chiefly at new stations. On the return trip Rafinesque passed through Bethlehem and visited with the botanist L ewis D. De Schweinitz. A trip was taken to New Jersey, thence on to New York, Staten Island, and to Long Island. In 1829 only two small journeys were taken, one in the spring to the pine barrens in New Jersey, and the 
second in the summer to New York by steamboat, thence to Norwalk in Connecticut, and to Hempstead on Long Island. In I830 a trip was made in the spring to New Jersey, and during the summer to the Catskill Mountains in New York. The return was by way of Albany where Rafinesque met Dr. Lewis C. Beck and Mr. J. Eights, and at Troy his old friends Eaton and Hales. While here Rafinesque delivered several lectures in the Rensselaer school.

In I83I the mother of Rafinesque died at her home in Bordeaux, France. She had desired her son to return to France and Rafinesque was inclined to go, but the events of I830 in Europe made him hesitate and later circumstances removed the opportunity. The only brother of Rafinesque died at Havre in 1826.

In I83 I trips were made to stations in Delaware and New Jersey. At Princeton, where Doctor Torrey was lecturing on chemistry, Rafinesque visited, and the two took to the fields on collecting trips. Later a trip was taken to New York and the Hudson and to New Lebanon to visit with his Shaker friend Lawrence. In I832 Rafinesque began publishing a quarterly journal called The Atlantic Journal and Friend of Knowledge, which he continued for two years. During its publication he secured the enmity of G. W. Featherstonhaugh and Richard Harlan.

About this time Baron Cuvier commissioned Rafinesque to collect the fishes of North America and send them to Paris where the museum authorities were to pay all expenses. While details were being arranged Cuvier died and the scheme lapsed.

In I832 a trip was made to Baltimore on the Newcastle 
Railway, probably the first trip Rafinesque ever made in that manner. Returning to Philadelphia he took the cholerine and finding the cholera approaching the city he left immediately for the mountains by way of Baltimore, taking the Fredericktown Railway through the Patapsco hills. Recovering soon after he spent the season at various places in or near the mountains. When the cholera left Philadelphia he returned by way of Harrisburg where he visited Governor Wolf.

During the year I833 Rafinesque spent some time exploring the marls in the pine barrens of New Jersey. He next essayed an extended journey through the southern Alleghanies to at least as far as Alabama. Heavy rains (after being lamed by an accidental fall) prevented the completion of the trip; Leesburg, Virginia, was the most southern point reached. Soon after the return he departed up the Schuylkill river and in July he was along the sea shore in New Jersey. A journey was made to New York and Troy where a course of lectures was delivered at the Rensselaer school. Lectures were also given at various other places, after which Rafinesque explored the country about the sources of the Susquehanna and Delaware rivers, and the valley of the Mohawk, returning to Philadelphia in September.

The summer of 1834 found Rafinesque eager for the outdoor life. Trips were made along the Delaware and the Schuylkill rivers.

For some years Rafinesque had had in mind the founding of a six per cent savings bank. By persistent effort he interested others. The plan was to issue stock to the amount of $\$ 50,000$ in 5,000 shares; depositors to be paid six per cent. Subscribers to the number of fifty took 
most of the shares; the first of June, 1835, the bank was organized and by September deposits were being received. The plan succeeded. The dividends for the first year amounted to as much as nine per cent. The worry and exertions of Rafinesque over this new business venture impaired his health and he concluded to spend the summer in the mountains. On the fourth of July, I835, he left Philadelphia on the railway, going to Columbia on the Susquehanna river. Here a boat was secured and the journey continued by easy stages up the canal or river by Harrisburg as far at least as Mahantango, visiting nearby and outlying points, and then up the Juniata river to Lewistown in the mountain region. Here the remainder of the summer was passed amid scenes and surroundings conducive to the health of a naturalist. By September Rafinesque returned by stage to Duncan Island at the mouth of the Juniata river, by boat to Harrisburg and Columbia, and by rail to Philadelphia. He felt restored to perfect health and began toiling in the bank as actuary of the institution. The new employment kept Rafinesque from roaming but gave him time to compose his larger works, many of which soon began to appear. In 1836 he published a small book of one hundred and forty-eight pages, entitled: A Life of Travels and Researches in North America and South Europe. It is a characteristic but interesting, though somewhat crude narrative. This book is now very rare. It contains about all that is known of the private life of Rafinesque. The fragmentary accounts and sketches of his life now extant are all more or less replete with errors, some of them grotesquely so.

While a resident of Lexington, Rafinesque helped to 
form (in 1822 ) a literary club which later became the Kentucky Institute. He says :

I became the Secretary of it. We met weekly, to read Essays, discuss questions, \&c. But trifles alone were welcome as well as good suppers: my communications were too learned. I had to become a Poet, I read and published some light Poetry; but my Poems are mostly yet mpts. The most striking were the Instability of the world, Despondency, the Western flowers, \&c. with the Rives de l'Ohio in French. ${ }^{28}$

The poem, Instability, was elaborated and published, along with some minor pieces, in 1836 , and strange as it may seem, actually passed through two editions during the year. Other publications of the same year were: The American Nations, or Outlines of Their General History, in two volumes; New Flora and Botany of North America, in four parts; and Synoptical Flora Telluriana. Explorations at this time were confined chiefly to southern New Jersey and the pine barrens. ${ }^{29}$

In 1837 Rafinesque published his scheme of banking in a book entitled: Safe Banking, Including the Principles of Wealth. Another publication was: The Universe and the Stars. In 1838 there appeared: The Ancient Monuments of North and South America; Genius and Spirit of the Hebrew Bible; Alsographia Americana; Celestial Wonders and Philosophy, or the Structure of the Visible Heavens; and Sylva Telluriana. In I839 the publications were: American Manual of Mulberry Trees; and Improvements of Universities, Colleges, and other Seats of Learning. While Autikon Botanikon, three parts; The Pleasures and Duties of Wealth; and The Good Book, and Amenities of Nature, or Annals of Historical and Natural Sciences, were issued in $\mathrm{I} 84 \mathrm{O}$.

But the end was at hand. Hard work, close confine-

${ }^{28}$ Rafinesque, Life of Travels, pp. 72-73.

29 Rafinesque, New Flora, p. 10. 
ment, and disease made inroads upon the once powerful frame, and the life of Rafinesque closed on September I8, I840. Death found the toiler in reduced circumstances, dwelling in a garret, and alone. The immediate cause of death was cancer of the stomach and liver. ${ }^{30}$

It is related that Dr. William Mease, a faithful friend, prepared the body for burial. On returning later with the undertaker, Mr. Bringhurst, and a few friends it was found that the Shylock landlord had removed the remains to an adjoining room and locked the door, with the idea of selling the body to a medical school. The door was forced, the remains taken out by the rear of the building, and conveyed to a little church yard, then outside the city, and buried. The place is now known as Ronaldson's cemetery, Ninth and Catherine streets, a locality now absorbed by the growth of Philadelphia.

Rafinesque left a will which is on file in the archives of Philadelphia. From it a few items concerning his domestic life are revealed. Only here is it found that Rafinesque was married in Sicily in I809 to Josephine Vaccaro. In I8I I, a daughter, Emily; and in I8I4, a son, Charles Linneus, were born. The son died the following year. The wife and mother proved frivolous and in 18 I 5 on receipt of the news of the shipwreck of her husband forgot her allegiance and married a comedian named Giovanni Pizzarrone and wasted the property remaining in her hands. The daughter, Emily, became a stage singer. It is further learned that the brother of Rafinesque left two children, Jules and Laura, and that the sister of Rafinesque died in about the year I834. The daughter, Emily, and the nephews, Jules and Laura, were made the

${ }^{30}$ Haldeman, American Journal of Science, vol. 42, p. 280. 


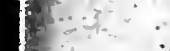

.

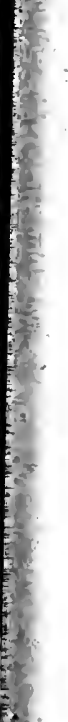




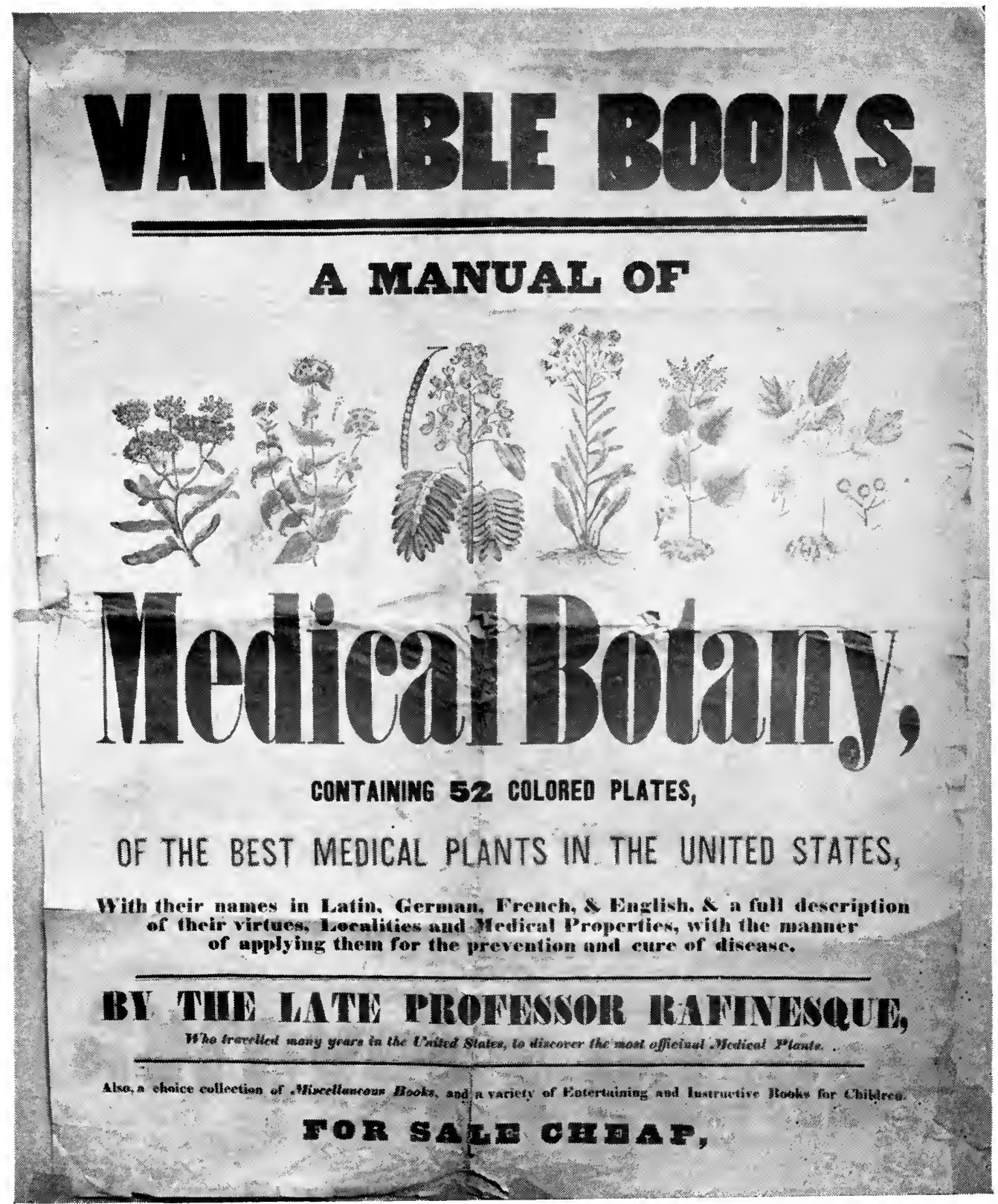

Facsimile of a broadside, $19 \times 24$ inches, distributed to advertise the sale of the personal effects of Rafinesque 
beneficiaries of the will jointly with various philanthropic proposals. Professor John Torrey, Dr. James Mease, Professor James Green, with others were named as executors. The will was probated November 16, I840, and was signed as executor by James Mease, November 28, I840.

The will provided for private sale but not much if any attention was paid to its provisions. The personal effects, said to have amounted to eight dray loads, were taken to the auction rooms of the city. Large three-colored posters were distributed announcing the sale. Connoisseurs were on hand and eagerly helped themselves much to their liking. The sale was so managed that the estate was indebted to the administrator in the modest sum of fourteen dollars and forty-three cents.

In summing up it may be stated that Rafinesque was no ordinary man. He had fairly well defined opinions of the theory of evolution, thus antedating Darwin. He had some idea of the modern germ theory of disease. He was a pioneer in American archaeological investigations, a pioneer teacher of modern languages, and a pioneer object teacher. He was an earnest advocate of the natural classification in natural sciences while all his contemporaries held to the old Linnæean artificial system. He was also the inventor of the coupon system. What more is needed to give a man distinction?

General George W. Jones of Dubuque, Iowa, a student at Transylvania University from I82 I to I825, has left the following account of his teacher, Rafinesque:

I recollect the learned Professor Rafinesque perfectly well and his physiognomy and general appearance are now visible to my mind's eye. He was in personal stature about the size and appearance of my deceased friend, the late John Quincy Adams, but I think he had a full suit of hair and black eyes. Professor Rafinesque had a room in [the] College proper, 
and was a man of peculiar habits and was very eccentric, but was to me one of the most interesting men I have ever known.

$\mathrm{He}$ often lectured to the students in College and in a most entertaining manner to the great delight of his audiences. His lecture on the ants was peculiarly instructive and interesting, causing many of the students to laugh heartily when he gave us the history of ants, especially when he described them as having lawyers, doctors, generals and privates, and of their having great battles and of the care by physicians and nurses of the wounded, etc., etc.

I would now give any reasonable sum to hear him repeat one of his lectures that $I$ listened to in Transylvania University. ${ }^{31}$

This was writen in 1894, seventy years after the occurrences. Evidently Rafinesque made an impression. $\mathrm{He}$ is frequently referred to as eccentric, sometimes in a disparaging tone. Critics seem to forget that eccentricity may be found in every university in the land and some of the cases are very pronounced.

\section{President Jordan in speaking of Rafinesque says:}

Nevertheless, no more remarkable figure has ever appeared * * in the annals of science. To me it has always possessed a peculiar interest. * * * American naturalists have greater honor now than forty years ago. Rafinesque died unnoticed, and was buried only by stealth. A whole nation wept for Agassiz. But a difference was in the men as well as in the times. Both were great naturalists and learned men. Both had left high reputations in Europe to cast their lot with America. Agassiz's great heart went out toward every one with whom he came in contact; but Rafinesque loved no man or woman, and died as he had lived, alone. If some one who loved him had followed him to the last, it might have been with Rafinesque as with Albrecht Dürer: " Emigravit' is the inscription on the headstone where he lies." But there was no one; and there is neither headstone nor inscription, and we know not even the place where he rests after his long journey. ${ }^{32}$

The eminent English naturalist, William Swainson, who resided for some time in Sicily, a friend of Rafinesque as well as his companion in many a ramble over the island, has left the following appreciation published in 1838 , two years before the death of Rafinesque:

${ }^{31}$ Call, Life and Writings of Rafinesque, pp. 43, 64.

32 Jordan, Science Sketches, pp. 143, 159. 
The year 1810 was remarkable in the annals of our science for the appearance of two important works on the ichthyology of the Mediterranean: one was by M. Rafinesque Schmaltz, subsequently professor of natural history in Lexington, U. S.; the other, relative chiefly to the fishes of Nice, was from the pen of M. Risso. The first of these is of much importance; and, from particular circumstances, will claim more of our attention than would at first appear necessary. M. Rafinesque's Sicilian works are now become so very scarce (the greater part of the unsold copies having been lost at sea), that few naturalists will have the power of consulting them. His chief ichthyological work is a synopsis of "New Genera and Species of Animals and Plants" found by the author in Sicily; and this was followed by a pamphlet, entitled "Indice d'Ittiologia Siciliana." The details of the new views of M. Rafinesque, in regard to classification, are too long to be inserted in this volume, but they will be occasionally adverted to. The faults that have been dwelt upon in these two works are such as all authors, even M. Cuvier himself, is not exempt from; they seem to us, in short, too trivial for the notice of the historian, and too general to be affixed to any one author in particular. We freely admit that M. Rafinesque (then living as we were, in a remote part of Europe, cut off, by the late war, from all intercourse with the Continent) was not well informed upon the current and almost daily discoveries going on there; and that some few of his species then supposed new, were really not so: but who is exempt from such errors, if errors they are? or how are such coincidents to be prevented, when naturalists, in distant places, and unknown to each other, are working at the same time upon the same subject? On the other hand, it must not be concealed that M. Rafinesque anticipated, by nearly ten years, a very large proportion of the generic and sub-generic distinctions subsequently taken up in the Règne Animal, in the first edition of which it is clear that its learned author was totally unacquainted with the works above mentioned, or that he was unconsciously repeating, under new names, a considerable number of the genera and sub-genera long before established in the volumes of professor Rafinesque. It would have been well had these unintentional errors been rectified in the second edition, or in the general ichthyological work of MM. Cuvier and Valenciennes; but they are not so; and naturalists will judge how far this is consonant with common justicc, or with that law of priority which is the only safeguard to the reputation we all covet. The generic characters of Rafinesque are as simple and intelligible as those of Linnæus, and the derivation of their names strictly classical and euphonious. In regard to the majority of those species which have been termed "imaginary," or inaccurately described, our firm conviction is, that nearly all, eventually, will be as fully established as those of the best known in our systems. We have formed this opinion not from theory, but from actual observation, and from having verified, in many instances, the validity of Rafinesque's characters. 
In further justification of the opinions here advanced, it may be proper for me to state that I had the pleasure of M. Rafinesque's society, during the three years of my official residence in Sicily, from 1807 to 1810 , and again in 1812, when we were both at Palermo, prosecuting our botanical and ichthyological researches together. Circumstances have hitherto prevented me from giving them to the public; but an extensive series of drawings and descriptions, made from the life, of the Sicilian fishes, not only confirms the accuracy of $M$. Rafinesque, in mary instances where he has been charged with error, but affords strong grounds for believing that one half of the Sicilian species, said to be found also in the Atlantic Ocean, Britain, \&c., are, in reality, quite distinct. M. Rafinesque, unfortunately, was unable to publish more than a synopsis of his ichthyological discoveries; and his figures, being very slight, are often not calculated to clear up those doubts which the brevity of his descriptions sometimes creates: nevertheless, to one who examines the species on the spot, in a fresh state, there are few which may not be identified. M. Cuvier often asserts that all M. Rafinesque's species were described from preserved specimens; but this is an error - they were all taken from the life. We both used to frequent the fish-markets, and we procured all our specimens there, or from fisherman who were in our employ. I was frequently urgent with my friend to preserve, at least, such as were the most remarkable of his new genera, anticipating the incredulity that has since been attached to them; but this advice, unfortunately, he never adopted. The greater part of those which I examined, after being drawn and described, were thrown away or eaten; a military life not being suited to the formation of such collections: but many of those species met with near Palermo, were preserved in spirits, and sent to the British and Zoological Musettms; few, however, of these are now in existence. One cause, perhaps, of the errors of $M$. Cuvier regarding the Mediterranean fishes, may be, that he had only examined preserved specimens, either distorted by stuffing, or bleached and shrivelled by alcohol, so that it becomes often difficult to recognize the most common species. If I have dwelt too long upon this subject, I hope the benevolent and candid reader will excuse me: it has originated in my desire to do adequate, though tardy, justice to one whose whole life has been devoted to science, and who has been singularly unfortunate in his worldly concerns; who, notwithstanding his eccentricities, has a kind and bencvolent heart; and whose labours have never been appreciated as I think they deserve. But for this, M. Rafinesque would not, in advancing life, have to contend with pecuniary difficulties, from which a small pension from the American government, proverbially generous to her scientific sons, would set him free. ${ }^{33}$

${ }^{33}$ Swainson, The Natural History of Fishes, Amphibians, \& Reptiles, pp. 60-63. 
Asa Gray reviewed the botanical writings of Rafinesque that were known to him in The American Journal of Science, published in March, I84I. His first sentence erroneously states that Rafinesque was a Sicilian by birth. From his lengthy review the following paragraphs are selected. It is plain to the reader that Professor Gray had little patience with Rafinesque and his conceptions of genera and species to say nothing of his advanced ideas on the evolution and mutation of species.

Our task, although necessary, as it appears to us, is not altogether pleasing; for while we would do full justice to an author, who, in his early days, was in some respects greatly in advance of the other writers on the botany of this country, and whose labors have been disregarded or undervalued on account of his peculiarities, we are obliged, at the same time, to protest against all of his later and one of his earlier botanical works.

We have thus noticed, somewhat in detail, the earlier labors of $\mathrm{Mr}$. Rafinesque, in North American botany. In these, he had certainly shown no little sagacity; and, considering his limited advantages, he must be deemed a botanist of unusual promise for that period, notwithstanding the defects which, increasing in after life, have obscured his real merits, and caused even his early writings to be in a great measure disregarded. The botany of the United States offered, at that time, a fine field to a botanist acquainted with natural affinities; and Rafinesque was the only person in this country, who had any pretensions to that kind of knowledge. All we can justly say is, that he possessed talents which, properly applied, would have raised him to a high rank in the science, and that he early apprehended the advantages of the natural classification, although he was by no means well grounded in structural and systematic botany. As early as 1814, indeed, he sketched a general classification of organized beings, to which he continued to attach great importance; but there is nothing new in it except the names, the botanical portion being inerely an anagram of Jussieu's leading divisions. His fuller developments of this system certainly contain much that is novel, but at the same time very absurd.

A gradual deterioration will be observed in Rafinesque's botanical writings from 1819 to about 1830, when the passion for establishing new genera and species, appears to have become a complete monomania. This is the most charitable supposition we can entertain, and is confirmed by the opinions of those who knew him best. Hitherto we have been particular in the enumeration of his scattered productions, in order to facil- 
itate the labors of those who may be disposed to search through bushels of chaff for the grain or two of wheat they perchance contain. What consideration they may deserve, let succeeding botanists determine; but we can not hesitate to assert that none whatever is due to his subsequent works. These, like many of the preceding, are little known; but we shall continue our enumeration, and future writers can correct our opinion wherever they think we have done the author injustice. ${ }^{34}$

\section{These strictures were commented upon by Brinton as} follows :

He [Prof. Asa Gray] awards him considerable credit for his earlier investigations but much less for his later ones. To quote Dr. Gray's words: "A gradual deterioration will be observed in Rafinesque's botanical writings from 1819 to 1830 , when the passion for establishing new genera and species appears to have become a complete monomania." But modern believers in the doctrine of the evolution of plant forms and the development of botanical species will incline to think that there was a method in this madness when they read the passage from Rafinesque's writings, about 1836, which Dr. Gray quotes as conclusively proving that, in things botanical, Rafinesque had lost his wits. It is this: "But it is needless to dispute about new genera, species and varieties. Every variety is a variation, which becomes a species as soon as it is permanent by reproduction. Deviations in essential organs may thus gradually become new genera." This is really an anticipation of Darwinianism in botany. ${ }^{35}$

The zoollogist S. S. Haldeman wrote the following which was published about a year and a half after the death of Rafinesque:

Rafinesque was a most industrious man, and passed a great deal of work through his hands, relating to almost every subject. His life was made up of a series of vicissitudes, and his efforts were retarded by poverty, and the consequent necessity of making a living. His greatest fault as a naturalist was not so much, perhaps, the shortness and resulting obscurity of his characters, as his passion for "new species," and the recklessness with which he proposed them, without sufficiently examining the works of his predecessors. The author who pursues such a course, treats his fellow-laborers with disrespect, and prevents his works from being as much consulted as they may deserve; for there is nothing to compel other authors to wade through unsatisfactory descriptions, which must, in many instances, be referred to established species. Rafinesque was very credulous, which led him to believe the exaggerated accounts of the vulgar;

${ }^{34}$ Gray, American Journal of Science, vol. 40, pp. 221-237, 1841.

35 Brinton, The Lenâpé and Their Legends, pp. 149-150. 


\section{PLATE IIa}
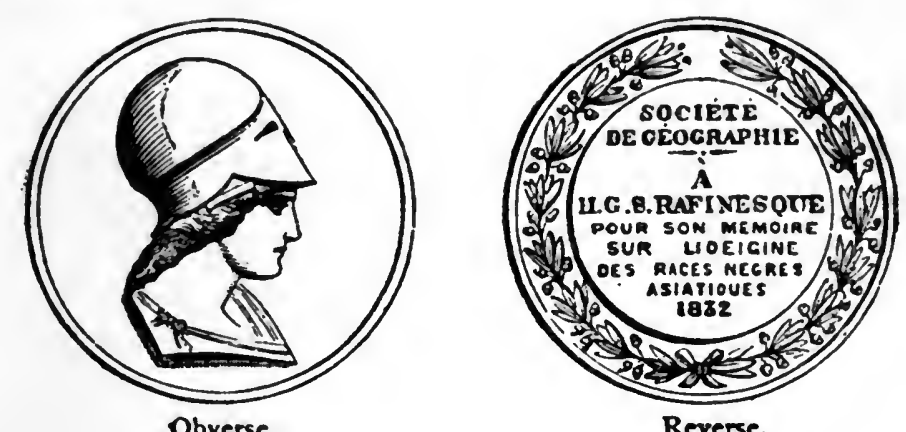

Gold Medal-Exact Fac.Simile.

Facsimile of gold medal awarded Rafinesque by the Geographical Society of Paris.

This medal was in the possession of Dr. Wm. Kent Gilbert, of Philadelphia, in 1876 . Its present possessor is unknown to the writer.

In one of Rafinesque's notebooks preserved in the Library of Congress the following original document may be found as an insertion:

Received Febr 8. 1841 of C. A Paulson Sixteen dollars $55 / 100$ for a gold medal presented to C. S. Rafinesque, by the Geographical Soc. of Paris to him. the asaid sum being the valuation of the medal by mr Echfeldt of the U S. mint.

Also five dollars for Several note books in mss of the said Rafinesque.

James Mease Executor

Weight of the medal 17 pwt 19 grains. at 93 cents per pwt. 
and to write essays and found "species," upon grounds which should be beneath the notice of any naturalist. ${ }^{36}$

\section{In I876, Theodore L. Chase published an appreciation} of Rafinesque from which the following paragraphs are taken:

The interval from 1825 to 1830 he devoted to scientific excursions through the States of Ohio, New York and Virginia, making frequent contributions to various scientific journals and societies. To the Geographical Society of Paris he sent a memoir on the primitive negroes of Asia and America, for which he received the gold medal of the society, with a diploma of merit, the first instance of such an honor being awarded to an American citizen.

He submitted a paper (250 pages of manuscript) in competition for a prize of $\$ 100$ offered by the Academy of Science in Boston, for the best account of the materials yet existing for a history of the nations and tribes of America before Columbus. The committee decided that his was the best, but did not award it the prize because it was too long. Its length, however, did not prevent its being incorporated without credit in the work of another writer, published shortly afterward.

Rafinesque was ever busy gathering materials, but had not the means to enable him to publish systematically the result of his labor. ****

Rafinesque lived half a century in advance of the time that men's minds were prepared to weigh justly the value of his discoveries. Such is the result of progress that the propositions we accept to-day as uncontrovertible truth, would, forty years ago, have been almost universally rejected. The publications of Rafinesque relating to American history, were unread in their day, and author and works forgotten afterwards, except by a very few.

Lately the attention of Investigators has been attracted to them in consequence of the writings of the Abbe Brasseur de Bourbourg, who following the same path of research, and with ample means at command has been enabled to elaborate subjects only briefly discussed by Rafinesque.

Letters of Rafinesque are in existence, showing that he had made advanced progress in decyphering inscriptions on Central American monuments. Much of the valuable information contained in De Bourbourg's eight volumes was outlined forty years previously in the writings of Rafinesque. ***

In botanical science he was greatly in advance of other writers in this country, and it is said that he was the only one at that time who had any knowledge of the natural classification of plants. His mind seems to have grasped all subjects connected with natural science, and the orig-

${ }^{36}$ Haldeman, Am. Jr. Science, vol. xlii, p. 281, 1842. 
inality of his ideas eliminated truths that the scientific men of those days could not comprehend. He wrote with great facility, and the papers from his pen published in American periodicals are characterized by a concise and expressive diction, minuteness of detail and exhaustive treatment of the subject considered. He handled his topic throughout its length and breadth so as to cover every point that might in any degree be opened to controversy.

The versatility of his acquirements enabled him to.occupy the foremost ground, not only in natural history, but in antiquities, civil history, philology, political economy, philosophy, and he even completed a poem of nearly six thousand lines. The "Genius and Spirit of the Hebrew Bible," was, I believe, the last ${ }^{37}$ volume he published, and ended the literary career of one who, had his efforts for the advancement of science met with even moderate encouragement," would have left a valuable legacy to posterity, by placing in permanent form the experiences and discoveries that an industrious life had accomplished in scientific pursuits.

The latter portion of his life was embittered by impoverished cir. cumstances that compelled the withdrawal of his mind from his chosen pursuits, in the effort to procure the means of support, and he was cellsured regarding the methods employed in accomplishing those ends. It is to be regretted that his writings have been, from the manner of their publication, so scattered as to be little known to men of science. It is seldom that copies of any of his works are to be obtained, all of them having been issued in small editions, and but few copies of these it is presumed have been preserved. ${ }^{38}$

William H. Dall in his remarks on some American conchologists speaks of Rafinesque with apparent frankness as follows:

One of the most singular figures in the portrait gallery of scientific men, eccentric as many of them have always been considered, is that of Constantine Samuel Rafinesque-Schmaltz. * * * * He traveled furiously, and collected wherever he went $* * * *$ Rafinesque was a marked example of the adage, "Great wit to madness nearly allied is," and the workings of a mind of unusual acumen, briiliancy, and activity were always clouded by a certain incoherency, due to his highly excitable and versatile temperament. He possessed talents which, properly regulated, would have carried him to the front rank of scientific workers. In 1836 we find him insisting, in his Flora Telluriana, that new species and new genera are continually produced by deviation from existing forms. Every variety is a deviation which becomes a species as soon as it is

${ }^{37}$ Erroneous, see Bibliography.

${ }^{38}$ Chase, Potter's American Monthly Illustrated Magazine of History, Literature, and Art, vol. vi, no. 50, pp. 99-101, February, 1876. 
fixed sufficiently to constantly reproduce its kind. Many of the genera he suggested are fully recognized to-day, though by his contemporaries regarded as worthless. * * * Even in his direst poverty he always retained friends and admirers. It is certain that he must have possessed many lovable qualities. ${ }^{30}$

The gifted scientist, G. Brown Goode, thus writes with happy appreciation:

The most remarkable naturalist of those days was Rafinesque, a Sicilian 40 by birth, who came to Philadelphia in 1802.

Nearly fifty years ago this man died, friendless and impoverished, in Philadelphia. His last words were these: "Time renders justice to all at last." 41 Perhaps the day has not yet come when full justice can be done to the memory of Constantine Rafinesque, but his name seems yearly to grow more prominent in the history of American zoölogy. He was in many respects the most gifted man who ever stood in our ranks. When in his prime he far surpassed his American contemporaries in versatility and comprehensiveness of grasp. He lived a century too soon. His spirit was that of the present period. In the latter years of his life, soured by disappointments, he seemed to become unsettled in mind, but as I read the story of his life his eccentricities seem to me the outcome of a boundless enthusiasm for the study of nature. . . . . The most satisfactory gauge of his abilities is perhaps his masterly "Survey of the Progress and Actual State of Natural Sciences in the United States of America," printed in 1817. His own sorrowful estimate of the outcome of his mournful career is very touching: "I have often been discouraged, but have never despaired long. I have lived to serve mankind, but have often met with ungrateful returns. I have tried to enlarge the limits of knowledge, but have often met with jealous rivals instead of friends. With a greater fortune I might have imitated Humboldt or Linnæus." ${ }^{42}$, 43

The following estimate of Rafinesque is interesting and in some ways remarkable:

${ }^{39}$ Dall, Proceedings Biological Society of Washington, vol. iv, pp. 114-117, 1888.

40 Erroneous; Rafinesque was born in Galata, a suburb of Constantinople.

41 Rafinesque used these words in his Life of Travels, p. 93. They were written sometime before 1836 , several years before his death. The exact sentence is: "But time renders justice to all at last."

42 This quotation is apparently from Rafinesque, Life of Travels, pp. 113-114, but varies in minor details.

43 Goode, Proc. Biol. Soc. of Washington, vol. iv, pp. 25-26, 1888. The same occurs in Report of U.S. National Museum, 1897, part 2, p. 420. 
The other contemporary of Dr. Torrey was French in ancestry, a Turk by birth, a Sicilian by adoption, and a vagabond by nature, gifted, versatile, wildly enthusiastic, erratic, much maligned and never understood either by his contemporaries or by his biographers. His name was Rafinesque, which lends itself in rhyme with picturesque and grotesque, and both these adjectives fit him closely as the unique character of American botanical history. So ardent was he in his desire for new descriptions, that when there were no further plants within reach, he took flight to the clouds and deliberately classified the form of thunder and lightning. ${ }^{44} \mathrm{He}$ published voluminously and so miscellaneously that some of his papers are still coming to light. Much of his work is worthless, yet there are veins of good interlarded among the bad that it still remains the task of the future to sift and save. In his crazy notions regarding the multiplicity of species, Rafinesque has had no equals, a few weakling imitators, and only one real successor. ${ }^{45}$

The versatile writer and editor, Thomas Meehan, a long time resident of Philadelphia, has written the following appreciation of his fellow citizen:

In all ages there have been men in the history of science far ahead of their contemporaries, and frequently it has been the work of succeeding generations to do them the justice their work deserved. Of this class is Professor Constantine Rafinesque, who died in Philadelphia, September 18th, 1842. In the scientific literature of the present day the name of Rafinesque is continually appearing, and yet no one in the scientific world, except a few in our city, who have recently located his remains in an obscure grave lot in Ronaldson's Cemetery, Ninth and Catharine streets, cared to inquire where the great scientist was buried. It is said that these gentlemen propose to remove the ashes in the spring to a more honored spot, and some fuller account of him will be, therefore, appropriate.

In the biography of prominent men of science, the life of Rafinesque is yet comparatively unknown. He gave a slight sketch of his history in a small work, published in 1836, entitled "Life and Travels." What little he gave here is all that has been recorded. Like a brilliant meteor, he appeared in the United States, in 1802, without, apparently, any note heralding the coming of a radiant intellect. He only remained as an explorer three years. No one seems to know where he came from. No one knew where he went on his return. He came back in 1815, when he seems to have reached the front ranks as an eminent son of science. Certainly a large number of learned societies in this and other countries honored him by election to membership, besides bestowing on him more substantial evidences of high regard. Dr. Asa Gray, who, possibly, has not been ex-

44 See Bibliography, no. 302.

45 Underwood, Popular Science Monthly, vol. 70, pp. 511-512. 
celled as a severely just critic when he deemed occasion demanded vigorous treatment, in a review, in 1841, of Rafinesque's works, candidly states that his earlier labors came to be undervalued on account of his later developed peculiarities; that he was, certainly, a highly gifted man; and that he was far in advance of other writers on the botany of this country.

Others saw the coming failure of the Linnean artificial system of botany; but he was among the earliest to lead students toward the natural classifications now prevalent - and he was an earnest advocate of the doctrines of evolution which have since made Darwin and his followers famous. Even Professor Asa Gray, who subsequently became one of the ablest of Darwin's disciples, though in a qualified degree, in the review of 1841 above cited, takes occasion to deride and style as "extraordinary" Rafinesque's proposition that "new species and new genera are continually produced by derivation from existing forms."

It is little wonder that in those days, when the fixity of species from the beginning of creation down to our time, was an article of scientific faith, as well as the faith of the ultra-theologian, that such a proposition should evidence a madman, wholly aside from any eccentricities of classification and nomenclature. For madman they regarded him. In a letter to Dr. Darlington, dated from Wilmington, February 4th, 1819, Dr. Baldwin, a distinguished botanist of that time, writes: "I had an opportunity, for the first time, of attending a meeting of the Academy of Natural Sciences. Two communications, on new genera, from the redoubtable pen of Rafinesque, a member of 10,000 learned societies, had been examined by a committee, and rejected as unworthy of publication. I was rejoiced to see that the members of the Acadeny had sufficient independence to reject the wild effusions of a literary madman. ${ }^{46}$ By referring to the minutes of the Academy it appears the papers proposed to establish two genera of fossil Medusae. Who could at that time believe in even the possibility of a fossil jellyfish! And yet since this "madman" was so gallantly overthrown, this impossibility, then, is a proof actual now.

A flora of the then Territory of Louisiana (Flora Ludoviciana) was his first grand mistake. One Robin, after whom our locust (Robinia) has been named, collected or pretended to collect and made notes on the plants of that region. It is believed that he knew far less, and was less accurate, than Rafinesque evidently supposed. New genera and species were described that were indescribable, and much trouble and confusion arose. In his view, also, variations now regarded as immaterial were deemed worthy of specific rank and had specific names accordingly, until the nomenclature bid fair to break down botanical science by its sheer weight. Even the amiable Dr. Darlington, who rarely had an ill word for any one, had to note in his "Memorials of Bartram and Marshall" that

46 Doctor Baldwin was an irascible and anæmic individual, hence this choleric and extravagant statement finds ready explanation. 
"his peculiar views and extravagant innovations in nomenclature were rather injurious than beneficial to the science."

Again, in his weakness, Rafinesque was free and often unjust in his criticisms of others. In this he sowed the wind and reaped the whirlwind. A remarkable plant was found on the Wissahickon. Dr. Kuhn, a botanical lecturer in Philadelphia, who had been a student under Linnæus, took it to his old master who named it Kuhnia. Of this Rafinesque wrote: "Kuhn was but a poor botanist, and hardly deserved to have such a fine genus named after him. He did not find the plant, but only took it to Linnæus, who was flattered because his students gave the first botanical lectures in America; but he has written nothing." Few of his contemporaries escaped such sneers, and he was repaid with compound interest.

The chapter of Rafinesque's weakness closes here. On the other side he brought us a highly finished education, wealth and brilliant talents all of which he spent, as he believed, in the service of man. He travelled over most of what was then known as the United States and Territories, tens of thousands of miles, and always on foot, adding largely to the great sum of human knowledge, dying very nearly a pauper's death. In the struggle between sickness and starvation, with the determination still to owe no man, he excited the sympathy of the amiable botanist, Elias Durand, who charitably bought his herbarium, which had been miserably cared for, and profusely illustrated by tracings of rats, and the best of these are now in the "Herbier Durand" in the Jardin des Plantes at Paris. The balance of the herbarium went with the waste paper noted in the executor's return below given, from which, however, some specimens were rescued by Mr. Isaac Burk, still living, and which he presented as part of his herbarium to the University of Pennsylvania.

The will, rescued from oblivion by the energy of Mr. Millard Reeves, of the PUblic LEDGER, appended herewith, throws unexpected light on the history and character of this remarkable man. He was not the happy bachelor he has hitherto been supposed to be, but, like so many others, had a skeleton in the closet, which he carefully guarded from the gaze of his fellow men.

It is remarkable that one who evidently lived to do good as he understood it - who supposed he would have, when he made his will, not only something for his family, but enough to warrant a thought of benefiting orphan girls, should die in a garret on Race street, between Third and Fourth streets, in the midst of his great collections, with nothing but a hard cot and pillow for furniture, and no living soul at hand to close his eyes.

'The PUBLIC LEDGER of 1877 states that, for some reason, his body was removed from among his collections after death and locked in an adjoining room, and the body had to be let down by ropes for Undertaker Bringhurst to bury him. The same chapter says that at that time nearly 
all his friends, but Dr. Jas. Mease, had deserted him, which the document here produced confirms.

It is sad to read that one, that the medal he hoped should forever remain in his family should be summarily tossed into the Mint as old gold ${ }^{47}$ - that the manuscripts which, judging by the Medical Flora of the United States, a truly valuable work even to this day - manuscripts on which he had depended for legacies and reputation - should have been sold for $\$ 5$ only, while even the herbarium paper brought over $\$ 20-$ and that his great collections of books and objects of natural history, costing $\$ 7$ to catalogue, $\$ 8$ to clean, $\$ 6$ to cart and $\$ 4$ to help fill eight wagon loads to the auction mart, should have only realized $\$ 22.29$ to the executor.

It is questionable whether a sadder ending to a great life has ever been recorded in history, and it is creditable to the botanists of the Academy of Natural Sciences that even at this late day his grave has been located, and some honor will be paid to the scientific work of one whose name is destined never to die in the annals of American science, notwithstanding the contempt in which, on account of eccentricities, he was held by the fellow-students of his own time.48

\section{AN APPRECIATIVE NATURALIST}

To all who walk afield or linger in quiet woods, contemplating the beauties of nature, there comes the thirst for knowledge that will not cease but burns as with a consuming fire. When nature is clothed at her best, the landscape verdant, the air exhilarating, the river passing with its shimmering sheen, the woods redolent with flowers and ringing with the songs of birds, then the buoyant naturalist is attune to nature and joyfully he worships at her shrine. Trials and hardships are mere trifles as compared with the realization of some worthy enterprise. The misfortunes and trials, the hopes and successes of a journeyman naturalist are nowhere better related than by Rafinesque in one of his publications. His lucid and lively recital runs thus:

During so many years of active and arduous explorations, I have met

47 This statement is probably erroneous, but the location of the medal is unknown to the writer.

48 This lengthy extract is from the Philadelphia Public Ledger, February $19,1891$. 
of course all kinds of adventures, fares and treatment. I have been welcomed under the hospitable roof of friends of knowledge or enterprise, else laughed at as a mad Botanist by scornful ignorance. Often deemed a herbalist and wandering doctor by the vulgar, I have allowed or indulged this harmless belief, and thereby elicited from many quarters the local knowledge of medical facts, which I have published in my Medical Flora of the United States.

I have seldom met with liberal enlightened men, who could believe that I was actuated by the pure love of knowledge and science; yet I have found such worthy men sometimes and their names are gratefully impressed on my memory. Such were J. D. Clifford, Alex. Walsh, Mess. Knevels, Adlum, Dr. Schultz, D. Jackson, H. Clay, Clinton, Meade, Maclane, Wells, Thompson, Aldie, \&c. who without being Botanists, or at most mere florists, could appreciate my pursuits and facilitate my researches. As to Botanists and Zoologists I made it a point to search for them and enjoy their society, mutually imparting our knowledge.

Such a life of travels and exertions has its pleasures and its pains, its sudden delights and deep joys mixt with dangers, trials, difficulties, and troubles. No one could better paint them than myself, who has experienced them all; but I must be brief in conveying a slight idea of them.

Let the practical Botanist who wishes like myself to be a pioneer of science, and to increase the knowledge of plants, be fully prepared to meet dangers of all sorts in the wild groves and mountains of America. The mere fatigue of a pedestrian journey is nothing compared to the gloom of solitary forests, when not a human being is met for many miles, and if met he may be mistrusted; when the food and collections must be carried in your pocket or knapsack from day to day; when the fare is not only scanty but sometimes worse; when you must live on corn bread and salt pork, be burnt and steamed by a hot sun at noon, or drenched by rain, even with an umbrella in hand, as I always had.

Mosquitoes and flies often annoy you or suck your blood if you stop or leave a hurried step. Gnats dance before the eyes and often fall in unless you shut them; insects creep on you and into your ears. Ants crawl on you whenever you rest on the ground, wasps will assail you like furies if you touch their nests. But ticks the worst of all are unavoidable whenever you go among bushes, and stick to you in crowds, filling your skin with pimples and sores. Spiders, gallineps, horse-flies and other obnoxious insects will often beset you, or sorely hurt you. Hateful snakes are met, and if poisonous are very dangerous, some do not warn you off like the Rattle-snakes.

You meet rough or muddy roads to vex you, and blind paths to perplex you, rocks, mountains, and steep ascents. You may often lose your way, and must always have a compass with you as I had. You may be lamed in climbing rocks for plants or break your limbs by a fall. You must cross and wade through brooks, creeks, rivers, and swamps. In deep 
fords or in swift streams you may lose your footing and be drowned. You may be overtaken by a storm, the trees fall around you, the thunder roars and strikes before you. The winds may annoy you, the fire of heaven or of men sets fire to the grass or forest, and you may be surrounded by it, unless you fly for your life.

You may travel over a[n] unhealthy region or in a sickly season, you may fall sick on the road and become helpless, unless you be very careful, abstemious and temperate.

Such are some of the dangers and troubles of a botanical excursion in the mountains and forests of North America. The sedentary botanists or those who travel in carriages or by steamboats, know little of them; those who merely herborize near a city or town, do not appreciate the courage of those who brave such dangers to reap the botanical wealth of the land, nor sufficiently value the collections thus made.

Yet although I have felt all those miseries, I have escaped some to which others are liable. I have never been compelled to sleep at night on the ground, but have always found a shelter. I have never been actually starved, nor assailed by snakes or wild beasts, nor robbed, nor drowned, nor suddenly unwell. Temperance and the disuse of tobacco have partly availed me, and always kept me in health.

In fact I never was healthier and happier than when I encountered those dangers, while a sedentary life has often made me unhappy or unwell. I like the free range of the woods and glades, I hate the sight of fences like the Indians! The free constant exercise and pleasurable excitement is always conductive to health and pleasure.

The pleasures of botanical exploration fully compensate for these miseries and dangers, else no one would be a travelling Botanist, nor spend his time and money in vain. Many fair-days and fair-roads are met with, a clear sky or a bracing breeze inspires delight and ease, you breathe the pure air of the country, every rill and brook offers a draught of limpid fluid. What delight to meet with a spring after a thirsty walk, or a bowl of cool milk out of the dairy! What sound sleep at night after a long day's walk, what soothing naps at noon under a shaded tree near a purling brook!

Every step taken into the fields, groves, and hills, appears to afford new enjoyments, Landscapes and Plants jointly meet in your sight. Here is an old acquaintance seen again; there a novelty, a rare plant, perhaps a new one! greets your view : you hasten to pluck it, examine it, admire, and put it in your book. Then you walk on thinking what it might be, or may be made by you hereafter. You feel an exultation, you are a conquerer, you have made a conquest over Nature, you are going to add a new object, or a page to science. This peaceful conquest has cost no tears, but fills your mind with a proud sensation of not being useless on earth, of having detected another link of the creative power of GoD.

Such are the delightful feelings of a real botanist, who travels not for 
lucre nor paltry pay. Those who do, often think only of how much the root or the seed or the specimen will fetch at home or in their garden.

When you ramble by turns in the shady groves, glassy glades, rocky hills, or steep mountains, you meet new charms peculiar to each; even the gloomy forest affords a shady walk. Every rock, nook, rill . . . has peculiar plants inviting your attention. When nothing new nor rare appears, you commune with your mind and your God in lofty thoughts or dreams of happiness. Every pure Botanist is a good man, a happy man and a religious man! He lives with God in his wide temple not made by hands.

\section{AN APPRECIATION}

Rafinesque was born in the sunny southland of Europe, in the land of oppression; a child of fortune when times were good but of adversity in troublous eras. His fate was to be cast during his formative period into the midst of a volatile public. Greece, France, and Italy were in turn the scenes of his childhood, the latter country remaining his home until he was over eighteen years of age. Coming to the United States in 1802 , he remained only about three years and was busily engaged in exploring the country. Returning to Italy he soon passed over to Sicily where for the greater part of the succeeding decade he was in the midst of pleasant surroundings.

Sicily, with her tropical verdure, her mountainous scenery, a primitive interior, and her shores yielding to culture, gave a rich and varied field for a naturalist. In this rich field Rafinesque wrought with increasing energy. Ten years on a beautiful and lovely island, years made full by personal gain, by appeasing the thirst for knowledge with frequent journeys to nature's fountain, and by association with an appreciative fellow naturalist, all these combined to render a generous enthusiasm boundless. Rightly could Rafinesque in after years refer to this epoch as the best and happiest of his life.

\footnotetext{
49 Rafinesque, New Flora, part I, pp. 11-15.
} 
Growing weary of the island and of its fickle inhabitants, Rafinesque embarked for the New World, taking many of his personal effects and a cargo for trade. The undertaking was auspicious, but nevertheless misfortunes soon followed; a long and stormy voyage was nearly closed, when shipwreck shattered all hopes. A less calamity has brought many a worthy man to an untimely death. Despair came; but soon a ray of hope appeared; friends were found; employment secured; and in time some insurance money was received for the lost cargo. A new start was made, but the perfidy of a Sicilian dissipated hopes and property. Adding to this the domestic troubles in Sicily, it would seem that the cup of sorrow was full enough. Events shaped themselves so as to give opportunity to visit the interior. The fame of Audubon, the brilliant promise of the rising Transylvania University, and above all the solicitations of a dear friend, Clifford, beckoned the traveler westward. It is a far cry from balmy Sicily to the wilds of Kentucky. In the latter region few congenial companions could be found; but there were the forests, the valleys, the rivers, and all things that walk or creep, run or swim therein; and the tumuli of the ancient dwellers stood as silent monuments on the hilltops or in the valleys, all inciting wonder and admiration.

Rafinesque well knew that he was a pioneer, not only as a dweller, but also in many of his varied efforts, for science was young in most of its fields. Much of his work that may be criticised seems well done when the times and conditions are duly considered.

To see, to know, to publish, became with him the ruling passion. Everything around him was in its pristine 
beauty, much was new to the world of science, and right easily could an enthusiast run wild.

Five times he crossed the Alleghanies and always on foot, the better to observe the grandeur of the scenery and to garner the fruits of nature. No toil seemed too great, no discomforts too prolonged, should there be even a promise of growing knowledge. To him riches were only a means to an end and that end was to benefit mankind by the increase and diffusion of knowledge in the way which he conceived as the best to fulfill his mission. Although his property misfortunes were of frequent recurrence, causing him much discouragement, yet he was never in despair long. His persistency of effort in the face of adversity, and further that so much was accomplished that was really good, bring a ready appreciation which only narrowness, bigotry, and preconceptions withhold. All brilliant intellects are subject to foibles. No nation and no clime produces exceptions to this rule. In fact it is frequently observed that the greater the intellect, the greater the foible. Every casual reader will recall frequent instances. Even those idolized generally by the willing public are subjected to vigorous and sustained attacks by precise narrators. This is to be expected.

Being without a university training, Rafinesque lacked the precision of the schoolmen, a deficiency which he partially overcame through almost boundless energy and enthusiasm. Sympathetic guidance from appreciative fellows would have prevented many mistakes. Envy, malice, distrust, and rivalry prevented aid. Individuals fall short of their mission who allow such unworthy motives to control them. It seems undoubted that Rafinesque would have reached the foremost ranks had he even received 
generous sympathy. As it is, he reached, almost unaided, a position where his fame will grow brighter with the passing of time and he will be appreciatively recalled long after the words of his calumniators shall have been forgotten. Such is the fate of mankind; some are famous only with their day and generation, others long after. This Rafinesque believed and consoled himself with the thought that time renders justice to all at last.

After a life filled with few triumphs and far too many disappointments the end found the toiler in moderate circumstances. Alone and unfriended he passed beyond the vale of life into a realm where faith pictures another world of flowers, of sweetly singing birds, and of loved ones found again; a naturalist's dream, a desired haven for the tempest-tried soul. 
BIBLIOGRAPHY 



\section{BIBLIOGRAPHY OF C. S. RAFINESQUE}

The writings of Rafinesque are varied and widely scattered as may be seen from a perusal of the following bibliography. Moreover it is extremely difficult to secure even an approximate knowledge of his writings as many of his books and papers were issued in small editions or else appeared in foreign journals which are not easy of access. Again many of his books were regarded as of no value and no care was taken for their preservation and as a result in many cases but few copies are known to exist.

In working up this bibliography the writer has had access to the collection of material in the Library of the State Historical Society of Wisconsin, the Library of the Missouri Botanical Garden, the Chicago Public Library, the Newberry Library, the John Crerar Library, the Library of the University of Chicago, the Library of the Gray Herbarium, Library of the Harvard Museum of Comparative Zoölogy, Library of Harvard University, Boston Public Library, Library of the Arnold Arboretum, Library of Yale University, New York City Public Libraries, Library of the New York Botanical Garden, Library of the Academy of Sciences of Philadelphia, the Library of the State University of Iowa, the Library of Congress, the Library of the U. S. Department of Agriculture, and the Library of the Smithsonian Institution. He has also corresponded with the officials of a number of other prominent libraries. The writer's collection of 
Rafinesque material, the result of years of effort, is considerable. From these sources the following bibliography has been compiled.

The writer feels that he has been more than usually favored and to all who gave assistance he returns grateful acknowledgments.

In the technique of the bibliography the aim has been to be consistent and accurate. All the titles included, except where otherwise mentioned, have been examined not only once but mostly many times in order to secure the greatest efficiency in transcription. A comparison of the titles with the plates given will indicate the rules followed.

Iowa City, Iowa, September I, I908

1 Rafinesque, C. Notice sur deux nouvelles especes des genres picoides et turnix de líle de Java, décrites à Philadelphie, dans le cabinet de M. Peales, par le C. Rafinesque. Bulletin des sciences, par la société philomatique, Paris, Veudemiaire, an 11 de la République, [1803], no. 67, p. 146.

The initials "F. M. D." occur at the close of the article. The title page to the volume gives the year "M.DCCC.XI", and the volume "tome troisième".

See number 2.

2 Rafinesque, C. Notice sur une hirondelle et un figuier de l'île de Java, décrits à Philadelphie, dans le muséum de M. Peales, par le C. Rafinesque. Bulletin des sciences, par la société philomatique, Paris, Brumaire, an 11 de la République, [1803], no. 68, p. 153.

The initials "F. M. D." occur at the close of the article. The imprint and volume as in the preceding title.

See number 1 .

3 [RAFinesque, C. S.]. Canvass-back duck and its food. Extract of a Letter from Mr. C. S. Rafinesque to Dr. Mitchill, dated Philadelphia, Sept. 7, 1804. The Medical Repository, second hexade, vol. II, no. II, p. 208, New York, August, September, and October, 1804. 
4 [RAFINESQUE, C. S. Announcement of a catalogue of the plants of the State of Delaware and of the District of Columbia.] The Philadelphia Medical and Physical Journal by Benjamin Smith Barton, vol. Ir, part I, p. 177, Philadelphia, 1805.

Rafinesque frequently claimed that the editor, Doctor Barton, suppressed the publication of this catalogue contrary to his promise, and apparently the claim is well founded.

5 [RAFInesque, C. S.] Additions to Michaux's Flora of North-America. In a Letter from Mr. Rafinesque, to Dr. Mitchill, dated Palermo, in Sicily, 8th August, 1805. The Medical Repository, second hexade, vol. III, no. Iv, pp. 422-423, New York, February, March, and April, 1806.

6 [RAFinesque, C. S.] Sicilian Quarantines and French Acid Fumigations. The Medical Repository, second hexade, vol. III, no. IV, p. 442, New York, February, March, and April, 1806. 1806.

Extract from a letter to Doctor Mitchill, dated Palermo, February 25,

7 Rafinesque-Schmaltz, C. S. Manifesto della, Pamphysis Sicula sive Historia Naturalis Animalium, vegetabilium et mineralium quae in Sicilia vel in circuitu ejus inveniuntur, opus incæptum a P. Franc. Cupani in Panphyto Siculo, continuatum ab Anton. Bonanno Gervasi, Jos. Steph. et Franc. Chiarelliis et ab C. S. Rafinesque-Schmaltz locupletatum etc. Palermo 1807. tab. 1.-Questo Prospetto è da per se alquanto interessante ; sfortunatamente per numerosi motivi non si pubblicò l'opera che annunziava, la quale avrebbe fatto onore alla Sicilia e restituito l'intiero Panphyton Siculum alla luce, con le sue 700 tavole circa.

Quoted from Specchio delle Scienze, vol. I, no. 1, p. 39, January, 1814. Prospectus of a proposed republication of the Panphyton Siculum.

8 [RAFInESQUe, C. S.] Prospectus of $M r$. Rafinesque Schmaltz's two intended Works on North-American Botany; the first on the new Genera and Species of Plants discovered by himself, and the second on the Natural History of the Funguses, or Mushroom-Tribc of America. The Medical Repository, second hexade, vol. v, no. Iv, pp. 350-356, New York, February, March, and April, 1808.

See number 15. 
9 Rafinesque Schmaltz, C. G. [S.] Essential Generic and Specific Characters of some new Genusses and Species of Plants observed in the United States of America, in 1803 and 1804. By $M r$. C. G. Rafinesque Schmaltz. In a Communication to Dr. Mitchill, dated Palermo, Sept. 1st, 1807. The Medical Repository, second hexade, vol. v, no. Iv, pp. 356-363, New York, February, March, and April, 1808.

See number 14.

10 Rafinesque Schmaltz, C. S. Notice on the Medical Properties of some North-American Plants: addressed to Dr. Mitchill by C. S. Rafinesque Schmaltz. The Medical Repository, second hexade, vol. v, no. IV, pp. 423-424, New York, February, March, and April, 1808.

11 Rafinesque-Schmalitz, C. S. Cinquanta figure di nuovi Generi e nuove Specie di Piante degli Stati Uniti di America, del Sign. C. S. Rafinesque-Schmaltz. Palermo 1808.-Di quest'opera sono soltanto stampate le tavole.

This work of which only the plates are said to have been published is quoted from Specchio delle Scienze, vol. I, no. 1, p. 39, January, 1814.

See number 232.

12 Rafinesque, C. S. Sei vedute ad acqua forte d'antichità Siciliane fatte incidere dal Sign. C. S. Rafinesque. Palermo 1808. Ne diamo una per saggio che rappresenta la Colonna della via Elorina, si veda il Viaggio di Biscari a tal soggetto.

This work is said to have been issued at Palermo, Sicily, in 1808. Quoted from Specchio delle Scienze, vol. I, no. 4, p. 141, April, 1814.

13 Rafinesque Schmacty, [C. S.] Sur les propriétés médicales de quelques plantes de l'Amérique Septentrionale; par $M$. Rafinesque Schmacty [Schmaltz], traduit du Medical Repository de New-Yorck; par M. Warden, Consul américain. Desvaux's Journal de botanique, vol. I, no. II, pp. 126-128, Paris, November, 1808.

14 Rafinisgue-Schmaltz, [C. S.] Description des Plantes trouvées dans les Etats-Unis d'Amérique, en 1803 et 1804, par M. Rafinesque-Schmaltz, communiquée à M. Mitchill, membre du Sénat des Etats-Unis, et un des Rédacteurs du Medical Repository de Ner-Yorck, dans une lettre datée de Palerme, 1 septembre 


\section{CARATTERI}

DI ALCUY JOVE GENERI

$$
\text { E NUOVE }=\text { ZECIE }
$$

D' A NLLM A L I E PIA NTE

$$
\text { DELLA SICILIA }
$$

SEgUITO DA UN CATALOGO DELLI JESCI

A CHE VI SI RITROUANO.

E Da ALTRI SAGGI DI STURIa NatuRALE

- IS OPUSCOLO

DEISIG.

\section{S, RAFINESQUE SCHMALT}

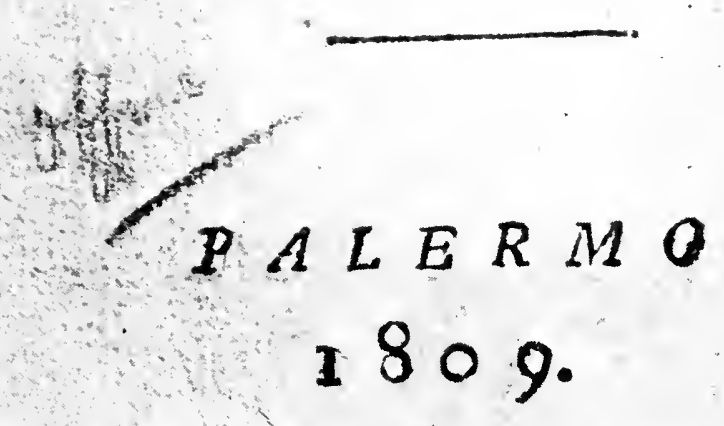

PER IE STAMPT DI SANEILIPPQ

Con approugzione

No. 16. Title to Part 1 of Rafinesque's "Caratteri" 
1807; traduite du Medical Repository, vol. 5, p. 356, avril 1808; par M. Warden, Consul américain. Desvaux's Journal de botanique, vol. 1, no. IV, pp. 218-234, Paris, January, 1809.

See number 9.

15 Rafinesque Schmaltz, [C. S.] Prospectus $d e$ M. Rafinesque Schmaltz, relatif à deux ouvrages sur la Botanique du Nord de l'Amérique; traduit du Medical Repository de New-Yorck, vol. 5 , p. 350, par M. N. A. Desvaux. Desvaux's Journal de botanique, vol. II, pp. 166-178, Paris, 1809.

See number 8.

16 Rafinesque Schmaltz, C. S. : | Caratteri | di alcuni nuovi generi | e nuove specie / d'animali e piante | della sicilia | seguito da un catalogo delli pesci | che vi si ritrovano | e da altri saggi di storia naturale $|-|$ opuscolo $\mid$ del sig. | C. S. Rafinesque Schmaltz | $\mid$ Palermo | 1809. | per le stampe di sanfilippo. $|-|$ Con approvazione. $\mid$

Octavo in size, quarto in fold, pp. [i-iv], [ia-iva], 3-105, [106 blank], plates $\mathrm{I}-\mathrm{xx}$. This is the pagination in the volume in the Library of Congress which volume has been carelessly arranged and rebound. The work evidently was issued in two parts. The first part having the above title and the pages [i-iv], 3-69, [70 blank]. The second part consequently had pages [ia-iva], 71-105, [106 blank], and the following title:

17 Rafinesque Schmaltz, C. S. : | Caratteri| di alcuni nuovi generi | e nuove specie / di animali | e piante della sicilia / con varie osservazioni sopra i medesimi. $|-|$ opuscolo | del sig. | C. S. Rafinesque Schmaltz $|\longrightarrow|$ Palermo $\mid$ 1810. | per le stampe di Sanfilippo. $|-|$ Con Approvaziont.

The above title is one usually found and quoted.

See Plates III and IV.

The salutation is dated: "Palermo 1. Aprile 1810."

Rafinesque notices this work in Specchio delle Scienze, vol. I, no. 1, p. 38, January, 1814.

The plates containing representations of 59 fishes, 6 flowering plants, and 12 other life forms, I have been unable to determine their distribution between the two parts.

Copies of this work are in the Library of Congress; Library of the Harvard Museum of Comparative Zoölogy; Library of the New York Botanical Garden; Library of the Academy of Natural Sciences of Philadelphia; Library of the Arnold Arboretum; The New York Public Library; Library of the Smithsonian Institution; Library of the British 
Museum; Library of the Historical Society of Pennsylvania; Library of the U. S. Department of Agriculture; and the Fitzpatrick Collection.

18 Rafinesque Schmaltz, C. S.: | Indice | d' ittiologia siciliana | ossia | catalogo metodico dei nomi latini, | italiani, e siciliani dei pesci, che / si Rinvengono in sicilia | disposti | secondo un metodo naturale | eseguito | da un appendice che contiene la descrizione | di alcuni nuovi pesci siciliani | illustrato da due piance. | -1 opuscolo del signore | C. S. Rafinesque Schmaltz $|-|$ Messina | presso Giovanni del Nobolo | con approvazzione | 1810. |

Paper, octavo in size, quarto in fold, pp, [1-6], 7-70, folding plates $1-2$.

The cover title reads:

| - Indice | d'ittiologia siciliana | - 1

Rafinesque notices this work in Specchio delle Scienze, vol. I, no. 1, p. 38, January, 1814.

Copies seen are in the Library of the Harvard Museum of Comparative Zoölogy; Library of Harvard University; Library of Arnold Arboretum; Library of the Academy of Natural Sciences of Philadelphia; and the Library of the Smithsonian Institution. There is also a copy in the Library of the British Museum as well as in the Library of the Historical Society of Pennsylvania.

19 Rafinesque Schmaltz, C. [S.] Progress in American Botany. By a letter from C. Rafinesque Schmaltz, Esq., of Palermo, in Sicily, to Dr. Mitchill, dated May 30, 1809, the following Botanical information is received. The Medical Repository, third hexade, vol. I, no. III, p. 197 [297], New York, November, December, 1809, and January, 1810.

20 Rafinesque Schmaltz, C. S.: | Statistica generale | di sicilia $\mid D e^{\prime}$ Signori | D. D. Giuseppe Emmanuele Ortolani | avvocato e mineralogico | e Constantino S. Rafinesque Schmaltz | negoziante e naturalista | in due parti | Nella prima si descrive il Fisico della Sicilia, | nella seconda il suo Morale. | Palermo | 1810 | dalla reale stamperia. |

Paper, octavo or $12 \mathrm{mo}$ in size according to trimming, quarto in fold, pp. [1-2], 3-49, [50 blank] and two folding maps of ancient and modern Sicily. Pages 6 and 7 are numbered 9 and 8 respectively. No print appears on the cover pages.

Rafinesque speaks of this work in Specchio delle Scienze, vol. I, no. 2, pp. 75 and 80, February, 1814. 
PLATE IV

\section{A R A T T E R I}

DI ALCUVI NUOVI GENERI

E NUOVE SPECIE

DI ANIMALI

E. FIANTE DELLA SICILIA

CON VARIE OSSGRVALIQIT SORRA I MEDESIMI ,

OPUSCOLO

D 2 c s ic.

C. S. RAFINESQUE SCHMALTZ

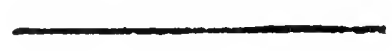

$P A L E R M O$

1810 .

PER LE STAMPE DI SAXPILIPPO .

Con Approvaziont.

No. 17. The second title to Rafinesque's "Caratteri" 
The copies examined belong to the Library of Harvard University; Library of the New York Botanical Garden; the Library of the Academy of Natural Sciences of Philadelphia; and the Library of the Smithsonian Institution.

21 Rafinesque Schmalit, C. S. An Essay on the exotic plants, mostly European, which have been naturalized, and noze grow spontaneously in the Middle States of North America. The Medical Repository, third hexade, vol. II, no. IV, pp. 330-345, New York, February, March, and April, 1811.

Addressed: "To Samuel L. Mitchill, New-York." Dated: "Palermo, 1st April, 1810."

22 [RAFINESQUE, C. S.] Botanical information concerning two Families of Plants. I. Species of the genus Callitriche. II. North American species of the genus Potamogeton. The Medical Repository, third hexade, vol. II, no. Iv, pp. 407-409, New York, February, March, and April, 1811.

From a letter to Dr. Mitchill dated Palmero, April 1, 1810.

23 Rafinesque-Schmaltz, C. S. Cento venti tavole del Panphyton Siculum di Cupani, nuovamente fatte incidere col rittatto di Cupani, dal Sig. C. S. Rafinesque-Schmaltz. Palermo 1812. fol. Il famoso Panphyton Siculum di Cupani è un opera cosi rara che forse sole 4 copie n'esistono in tutta la Sicilia e l'Europa, l'Autore di questa ristampe ne fece fare a gran spesa una copia esatta a ricalco, sopra l'esemplare della pubblica Libreria de PP. Gesuiti di Palermo, la quale contiene più di 650 tavole, e quindi ne fece incidere 120 scelte tavole per fare conoscere questa pregievolissima opera. 1814.

Quoted from Specchio delle Scienze, vol. I, no. 1, pp. 38-39, January,

24 Rafinesch Schmaltz, [C. S.] Description de quelques $V$ égétaux de Sicile et des Etats-Unis; par Rafinesch [Rafinesque] Schmaltz. Journal de botanique, appliquée à l'agriculture, à la pharmacie, à la médecine et aux arts, vol. [I], pp. 235-236, Paris, Mai, 1813.

25 [RAFinesque, C. S.] Champignons des Etats-Unis. Journal de botanique, appliquée à l'agriculture, à la pharmacie, à la médecine et aux arts, vol. [I], pp. 236-237, Paris, Mai, 1813. 


\title{
SPECCHIO DELLE SCIENZE
}

0

\section{GIORNALE ENGIGLOPEDICO DI SICILIA}

\author{
DEPOSITO LETTERARIO
}

DELLE MODERNE COGNIZIONI, SCOPERTE, ED OSSERVAZIONE SOPRA IE SCIENZE ED ARTI

E particolarmente sopra la Fisica, lia Chimica, 13 Storia Naturale, la Botanica, l'A Aricoltura, la Me. dicina, il Commercio, lis Legislazione, l'Educazione ec.

\section{TOMO PRIMO}

PRIMA ANNATA E PRIMO SEMESTRE.

Instruire utilement, est le but où $\ddot{j}$ aspive

\section{PALER $\mathrm{L}$}

Dallu Tipogritfin di Francesco Abate Qm. Domenica.

$$
2814 \text {. }
$$

No. 26. Title to "Specchio delle Scienze," Vol. I 
This Journal de botanique was published by N. A. Desvaux and is a continuation of his Journal issued in 1808-9. The above would be Volume III in continuation of the first series. The volume with a portion of the original covers that the writer has seen is in the Library of the Missouri Botanical Garden.

26 [RAFInESQUE, C. S.] : | Specchio delle scienze | o | giornale enciclopedico di Sicilia | deposito letterario / delle moderne cognizioni, scoperte, ed osservazioni | sopra le scienze ed arti | E particolarmente sopra la Fisica, la Chimica, la | Storia Naturale, la Botanica, l'Agricoltura, la Me- | dicina, il Commercio, la Legislazione, l'Educa- | zione ec. $|-|$ tomo primo | prima annata e primo semestre. | - Instruire utilement, est le but où j'aspire |- | Palermo | Dalla Tipografia di Francesco Abate Qm. Domenico. | 1814.

Octavo in size, quarto in fold, pp. [1-3], 4-216, plates 2.

See Plate V.

The dates of issue of the six parts composing this volume are:

Number I, I Gennaro 1814, pp. 1-44.

Number II, I Febbraro 1814, pp. 45-80.

Number III, I Marzo 1814, pp. 81-112, 1 tavola.

Number IV, I Aprile 1814, pp. 113-148, 1 tavola.

Number V, I Maggio 1814, pp. 149-180.

Number VI, I Giugno 1814, pp. 181-216.

The "Manifesto," pp. 3-6, is signed "Palermo 15. Settembre 1813."

The reverse of the title page has the following note:

"N. B. Tutte quelle Scoverte, ed Osservazioni, che in questo Giornale non porteranno un nome particolare d'Autore saranno proprie del Sig. C. S. Rafinesque Schmaltz."

The following articles appear:

27 Manifesto, pp. [3]-6. This is dated: "Palermo 15. Settembre 1813." Volume I, Number I, January, 1814, pp. 7-44. 10.

28 Geografia fisica. Osservazioni sopra il clima della Sicilia, pp. [7]-

29 Storia naturale. Nuova Veduta, o Divisione dello Studio Metodico dell' Istoria Naturale, pp. 10-11.

30 Classi somiologiche. O Quadro del Metodo Sinottico di Somiologia, pp. 11-15.

31 Ittiologia. Descrizione d'un nuovo genere di Pesce, pp. 16-17.

32 Botanica. Sopra due nuovi Alberi del Monte Etna, pp. 17-18.

33 Meteorologia. Osservazioni sopra la Pioggia terrosa seguita in Palermo nel Mese di Marzo 1813, pp. 18-19. 
34 Lettera dell Abate D. Francesco Ferrara Professore di Fisica nell Università di Catania, sopra l' anzidetto Fenomeno, pp. 20-21.

35 Legislazione. Decefilo-Num. 1, pp. 21-23.

36 Geologia. Compendio della nuova Teoria Volcanica e geologica del Sig. Patrin, pubblicata nel 1800 e 1804 e tradotta dal Francese, pp. 2325.

37 Agricoltura. Nomenclatura degl' Innesti, del Sig. Thouin, pubblicata nel nuovo Corso Compito d'Agricoltura teorica e prattica tomo 6. anno 1809. (traduzione dal Francese.), pp. 25-29.

38 Medicini-Fisiologia. Compendio delle Ricerche sopra le Funzioni della Milza, del Fegato, del Pancreas etc. del Dott. Rush di Filadelfia, pubblicate nel 1806. (traduzione dell' Inglese), pp. 29-31.

39 Chimica. Saggio delle ricerche del Sign. Davy di Londra sopra il Metallo della SODA, scoperto nel 1809 (traduzione dell Inglese), pp. 31-33.

40 Arti-Arte del fornaro. Descrizione della Madia ò Machina inventata dal Sign. Lembert di Parigi nel 1811, per impastare economicamente il Pane. (traduzione del Francese) Annali degli Arti, tomo 42, pp. 33-35.

41 Miscellanea. Bibliografia. Quadro della, Letteratura Siciliana nel principio di queslo secolo ò Raguaglio del' Opere stampate in Sicilia dal 1800 a tutto il 1812, pp. 35-40.

42 Invenzioni e Scoverte, pp. 40-43.

43 Obituario. Sono morto nell, Anno 1813, p. 43.

43a Società scientifiche e letterarie, p. 44.

Volume I, Number II, February, 1814, pp. 45-80.

44 Geografia fisica. Seguito delle Osservazioni sopra il Clima della Sicilia, pp. 45-47.

45 Agricoltura. Memoria sopra le Riforme che richiede l' Agricoltura Siciliana, pp. 48-51.

46 Economia politica. Paragone di alcuni Stabilimenti, Instituzioni, ed Usi economici ò politici d' Inghilterra e di Sicilia, pp. 51-53.

47 Botanica. Definizioni delle nuove Classi naturali di Vegetabili, pp. 53-54.

48 Materia medica. Illustrazioni di Materia Medica Siciliana, pp. $55-58$.

49 Legislazione. Dicefilo-Num. 2, pp. 59-62.

50 Agricoltura. Seguito della Nomenclatura degl Innesti del Sig. Thouin, pp. 63-65.

51 Chimica medica. Osservazioni sopra una Dissertazione del Dott. Guglielmo Wollaston relativa agli Calcoli e l'analisi delle Egestioni degli Uccelli, inserita negli atti della Società reale di Londra per 1810 e tradotte dall' Inglese, pp. 66-67.

52 Compendio delle Ricerche dei Sign. Vauquelin e Fourcroy sopra $i$ Calcoli urinari ed artritici (traduzione dal Francese), pp. 68-69. 
53 Legislazione. Descrizione delle Carceri di Filadelfia, Novajork, ed altre Città di America del Sign. Larochefoucauld Liancourt, Viaggio negli Stati uniti 1800. (traduzione dal Francese), pp. 69-71.

54 Arti. Modo di platinare il Rame del Sign. Strans, pp. 71-72.

55 Miscellanea. Seguito del Quadro della Letteratura Siciliana nel principio di questo Secolo ò dal 1800 al 1812, pp. 72-75.

56 Invenzioni e Scoperte Straniere, pp. 75-78.

57 Obituario, p. 78. Notizie Letterarie ed Avvisi, pp. 78-80.

Volume I, Number III, March, 1814, pp. 81-112.

58 Geografia fisica. Fine delle Osservazioni sopra il Clima della Sicilia, pp. 81-84.

59 Agricoltura. Prima Lettera di un Coltivatore all' Editore dello Specchio delle Scienze, pp. 85-86.

60 Botanica. Neogenito Esotico o Definizioni di cento nuovi generi di Piante Esotiche del Sign. C. S. Rafinesque, pp. 86-88.

61 Storia naturale. Osservazioni microscopiche fatte dal Sign. C. S. Rafinesque in Agosto 1812, pp. 88-90.

62 Metafisica. Piano de' Saggi Metafisici dell'Ab. Sac. D. Giusto Sugati di Misilmeri, pp. 90-93.

63 Letteratura. Programma alla libera traduzione poetica dell' Eroidi di Ovidio del Dott. D. Gioachino Fernandez di Catania colle risposte del medesimo, pp. 93-94.

64 Farmacia. Prospetto di un Trattato elementare di Farmacia secondo le cognizioni moderne di Storia naturale e di chimica di D. Antonino Arrosto, Messinese, pp. 95-96.

65 Fisica. Analisi di un Opera titolata, Del Galvanismo e della Elettricità metallica trattato del Dott. Carmelo Maravigna profess. e dimostr. di Chimica nella $R$. Università di Catania. Catania 1811. I. Tomo con I. Tavola, pp. 97-99.

66 Agricoltura. Fine della Nomenclatura degl' Innesti del Sig. Thouin, pp. 99-100.

67 Chimica. Epitome dei cambiamenti proposti nella Nomenclatura chimica, dal Sign. Brugnatelli, pp. 101-102.

68 Kaguaglio delle principali scoperte chimiche del Sign. Cav. Humphrey Davy, pp. 102-104.

69 Meteorologia. Osservazioni sopra la pioggia terrosa di Marzo 1813 ed analisi di quella del 1803, del Sign. D. Gioacchino Arrosto. Nel fa per tutti del 1814, pp. 104-106.

70 Legislazione. Seguito della Descrizione delle Carceri di Filadelfia, pp. 106-107.

71 Miscellanea. Seguito del Quadro della Letterarura Siciliana nel principio di questo secolo, o dal 1800 al 1812, pp. 108-110.

72 Invenzioni e Scoverte straniere, pp. 110-111.

73 Invenzione Siciliana, p. 112. Obituario, pp. 112. Avvisi, p. 112. 
Plate 4, Phyllepidum squarrosum was issued with this number.

The cover title to number 3 of volume 1 is as follows:

Num. III. 1. Marzo 1814. ann. I $|-|$ specchio delle scienze | o | giornale enciclopedico di sicilia | - | deposito letterario | delle moderne cognizioni, scoperte, ed osservazioni | sopra le scienze ed arti | E particolarmente sopra la Fisica, la Chimica, la | Storia Naturale, la Botanica, l'Agricoltura, la $\mathrm{Me}$ - | dicina, il Commercio, la Legislazione, l' Educa- | zione etc. | - I Instruire utilement, est le but où j'aspire | - | Palermo | Dalla Tipografia di Francesco Abate Qm. Domenico. | 1814. |

Volume I, Number IV, April, 1814, pp. 113-148.

74 Botanica. Ordini Eltrologici o Definiżioni degli Ordini della prime Classe delle Piante, L' Eltrogynia, pp. 113-115.

75 Seguito del Neogenito Esotico, pp. 115-117.

76 Metafisica. Fine del Piano de’Saggi Metafisici del Sac. D. Giusto Sugati di Misilmeri, pp. 118-121.

77 Farmacia. Fine del Prospetto del Trattato Elementare di Farmacia di D. Antonino Arrosto, pp. 121-123.

78 Medicina. Epitome di una Lettera sull' uso interno del Carbon di Legno nelle Febbri intermittenti, direttaci dal D. Francesco Calcagni, Palermo 10. Gennajo 1814. opuscolo, pp. 123-127.

79 Statistica. Lista Bio-Necrologica ò Ristretto delle Nascite e Morti nella Città di Palermo nel corso dell' anno 1812, ricavata dalle fedi mensili de' Parrochi dal Sig. Dott. Francesco Calcagni, pp. 127-128.

80 Istoria. Analisi di un opera titolata Considerazioni filosofiche $e e$ politiche sullo stato civile cavate principalmente dall' Istoria dell'antica $e$ nuova Imera con un prospetto di alcune Constituzioni dell' Europa moderna ed una Analisi di quella di Sicilia, opera del Cav. Dott. Antonio Inguagiato. Palermo 1814. I tomo in 4, pp. 128-129.

81 Materia medica. Seguito delle tre Illustrazioni di Materia Medica Siciliana del Sig. C. S. Rafinesque. 2. Esempio Botanico-Asphodelus ramosus, pp. $130-134$.

82 Fisica. Osservazioni sopra un' importante scoperta ed una nuova teoria dei fussi del mare, dei venti alisei G'c. del Sign. Giov. Wood, tradotte dall' inglese del Portafolio giornale letterario anericano, pp. 134 137.

83 Legislazione. Seguito della Descrizione delle Carceri di Filadelfia, pp. 137-138.

84 Arti. Mezzi di perfezionare la fabricazione dei Mattoni e delle Tegole del Sign. Niesman, pp. 139-140.

85 Miscellanea. Sequito del Quadro della Lelteratura Siciliana del 1800 al 1812, pp. 140-143.

86 Notizia di alcune Opere stampate in Inghilterra nel 1813 con i titoli tradotti in Italiano, pp. 143-144.

87 Scoperta Siciliana, p. 145. Invenzioni e Scoperte Straniere, pp. 145- 
147. Problema di Gcometria, p. 147. Notizie ed Avvisi, pp. 147-148. Addenda agli Ordini Eltrogici, p. 148.

A folding plate giving a view of the "ruined pillar in the Elorin road" was issued with this number.

The cover title of number 4 of volume I reads:

Num. IV. 1. Aprile 1814. ann. I. |- I specchio delle scienze $\mid$ o | giornale enciclopedico di Sicilia $|\longrightarrow|$ deposito letterario | delle moderne cognizioni, scoperte, ed osservazioni | sopra le scienze ed arti | E particolarmente sopra la Fisica, la Chimica, la | Storia Naturale, la Botanica, l'Agricoltura, la $\mathrm{Me}$ - | dicina, la Legislazione, l' Educazione, il Com- | mercio etc. | - Instruire utilement, est le but où j'aspire | - | Palermo | Dalla Tipografia di Francesco Abate Qm. Domenico. | 1814.

Volume I, Number V, May, 1814, pp. 149-180.

88 Commercio. Quadro ragionato del Commercio attivo della Sicilia, e dei suoi generi d' esportazione, pp. 149-153.

89 Botanica. Esempio del Metodo Sinottico di Botanica, illustrato nel primo Ordine della prima Classe dal Sig. C. S. Rafinesque, pp. 154-156.

90 Seguito del Neogenito Esotico, pp. 156-158.

91 Meteorologia. Osservazioni sopra le Stagioni, e le Pioggie in Sicilia, pp. 158-161.

92 Lettera del Sign. D. Ignazio Polizzi di Trapani in data delli 14 Marzo 1814, sopra una nuova pioggia terrosa, pp. 161-162.

93 Agricoltura. Esame dei Terreni nel contorno di Messina del Sign. D. Antonino Arrosto, pp. 163-164.

94 Agricoltura. Principj fondamentali della Coltura perpetua dei Terreni del Sign. Yvart, trad. dal francese, pp. 165-167.

95 Medicina. Osservazioni sopra la Teoria della Febbre, e le ricerche mediche del Dott. Rush, pp. 167-168.

96 Chimica. Analisi di alcune osservazioni del Sign. Cav. Davy sopra il gas ossimuriatico \& c. inserite negli Atti della Società Reale di Londra per 1811, traduzione dall' Inglese, pp. 168-170.

97 Legislazione. Seguito della Descrizione delle Carceri di Filadelfia, pp. 170-171.

98 Miscellanea. Fine del Quadro della Letteratura Siciliana dal 1800 al 1812, pp. 172-175.

99 Notizia di alcune Opere stampate in Inghilterra nel 1813, p. 176.

100 Scoperte ed Invenzioni, pp. 176-178.

101 Obituario, p. 178. Notizie ed Avvisi, pp. 178-180.

Volume I, Number VI, June, 1814, pp. 181-216.

102 Geografia. Nuova Divisione del Globo Terrestre del Sign. Rafinesque, pp. 181-184.

103 Nuova divisione geografica della Sicilia, pp. 184-187.

104 Materia medica. Fine delle tre Illustrazioni di Materia Medica 


\title{
SPECCHIO DELLE SCIENZE
}

$\mathbf{o}$

\section{GIORNALE ENGICLOPEDICO DI SICILIA}

\author{
DEPOSITO LETTERARIO
}

DELLE MODERNE COGNIZIONI, SCOPERTE, ED OSSERYAZIONI SOPRA LE SCIENZE ED. ARTI

E particolarmente sopra ta Fisica, Ia Chimica, la Somiologia, l'Agricoltura ; la Medicina, la Legis* lazione elc.
Scritto dal Signoro
C. S. R A F I N E S Q U E

TOMO SECONDQ

PRIMA ANNATA E SECONDO SEMESTRE -

Instruire utilement, est le but où. j aspire

\section{P A L E R M O}

Dalla Tipografía di Francesco Abate Qm. Domienico.

$$
1814 \text {. }
$$

No. 120. Title to "Specchio delle Scienze," Vol. II 
Siciliana del Sign. C. S. Rafinesque. 3. Esempio Mineralogico-Succinum electricum, pp. 187-191.

105 Botanica. Descrizione del Buphthalmum crassifolium nuova specie di Pianta delle vicinanze di Palermo del Sign. Rafinesque, pp. 191-192.

106 Fine del Neogenito Esotico del Sign. Rafinesque, pp. 192-195.

107 Agricoltura. Fine dell' Esame dei terreni del contorno di Messina del Sign. Antonio Arrosto, pp. 195-196.

108 Mineralogia. Osservazioni critiche sopra la Mineralogia di Sicilia del Sign. Ab. Ferrara di Catania, pp. 197-198.

109 Meteorologia. Risultati delle Osservazioni sopra $i$ Fenomeni atmosferici del Sign. Varley, pp. 199-200.

110 Chimica. Della proporzione di metallo ch' esiste in ogni sale metallico, del Sign. Gay-Lussac, trad. dal francese, p. 200.

111 Medicina. Dell'influenza della Luna nelie fébbri ed altre malattie del Sign. Balfour. trad. dall' Inglese, p. 201.

112 Uso delle foglie di Opunzia nei dolori reumatici \& c. del Sign. D. Brenneke, traduz. dal tedesco, pp. 201-202.

113 Belle arti. Saggio sopra una nuova maniera d'incidere chiamata Litografia o Incisione sopra pietra trad. dal franc., pp. 203-204.

114 Legislazione. Seguito della descrizione delle Carceri di Filadelfia, pp. 205-206.

115 Miscellanea. Supplemento al Quadro della Letteratura Siciliana dal 1800 al 1812, pp. 207-208. Correzioni, p. 208.

116 Aggiunta, pp. 208-209.

117 Notiza di alcune moderne Opere di Medicina e Chirurgia stampate in Inghilterra, pp. 209-210.

118 Scoperte ed Invenzioni straniere, pp. 210-213.

119 Necrologia, p. 213. Indice delle materie del primo tomo, pp. 213216.

120 Rafinesque, C. S.: | Specchio delle scienze | o | giornale enciclopedico di Sicilia / deposito letterario / delle moderne cognizioni, scoperte, ed $\mid$ osservazioni sopra le scienze ed arti $\mid$ E particolarmente sopra la Fisica, la Chimica, la | Somiologia, l'Agricoltura, la Medicina, la Legis- | lazione etc. | Scritto dal Signore | C. S. Rafinesque |- $\mid$ tomo secondo | prima annata e secondo semestre. $|-|$ Instruire utilement, est le but où j'aspire $\mid-1$ Palermo | Dalla Tipografia di Francesco Abate Qm. Domenico. | 1814. |

Octavo in size, quarto in fold, pp. [1-2], 3-196.

See Plate VI.

The dates of issue of the parts of this volume are:

Number VII, I Luglio 1814, pp. 3-32.

Number VIII, I Agosto 1814, pp. 33-64. 
Number IX, I Settembre 1814, pp. 65-96.

Number X, I Ottobre 1814, pp. 97-128.

Number XI, I Novembre 1814, pp. 129-160.

Number XII, I Decembre 1814, pp. 161-196.

Volume II, Number VII, July, 1814, pp. 1-32. 3-5.

121 Idrografia. Nuova divisione delle Acque del nostro Globo, pp.

122 Geografia. Nuovo Planisferio del Sign. Ab. Mango, pp. 5-6.

123 Botanica. Descrizione di una nuova pianta Siciliana, Saponaria Sicula, p. 7.

124 Osservazioni critiche sopra un nuovo opuscolo botanico, pp. 8-9.

125 Meteorologia. Fenomeno elettrico osserzato supra il Monte Etna, p. 9.

126 Letteratura. Quadro delle Instituzioni letterarie e scientifiché della Città di Londra nel 1813, pp. 9-13.

127 Statistica. Popolazione della Sicilia, pp. 13-16.

128 Pastorizia. Brevi instruzioni sopra gli Arieti Spagnuoli o Merini del Dott. D. Antonino Candela, pp. 16-18.

129 Letteratura. Premj decennali concessi dall' Instituto di Francia nell' anno 1810. traduz. dal francese, pp. 18-21.

130 Chimica animale. Osservazioni sopra le Ricerche Chimiche sopra il Sangue ed alcuni altri fluidi animali del Sign. W. Th. Brande, inserite nelle transazioni filosofiche del 1812. e traduz. dall'Inglese, pp. 22-23.'

13.1 Fisica. Risultato degli sperimenti del Sign. Cav. Giacomo Hall sopra la compressione, pp. 23-24.

132 Nuova Machina Aerostatica del Sign. Zacharia, p. 24.

133 Medicina. Osservazioni sopra l' Idropisia, traduz. dal Francese, pp. 24-25.

134 Legislazione. Seguito della Descrizione delle Carceri di Filadelfia, pp. 25-27.

135 Letteratura. Quadro della Letteratura Siciliana nel 1813, pp. 2729.

136 Invenzioni e Scoperte, pp. 29-32.

137 Notizie ed avvisi, p. 32.

Volume II, Number VIII, August, 1814, pp. 33-64.

138 Legislazione. Dicefilo. Numero 3, pp. 33-39.

139 Medicina. Analisi della seguente opera medica, Ricerche sulla peste bubbonica che attacca gli uomini e bruti, del Dott. D. Santi Romeo. Messina 1814, scritta dal Sign. N., pp. 40-41.

140 Somiologia. Osservazioni sopra gli Animali Polistomi, ed un nuovo Genere di essi, Polactoma, pp. 41-43.

141 Analisi di un Opuscolo Somiologico francese, titolato, Prìcis des Découvertes $\mathcal{E}$ des travaux somiologiques di C. S. Rafinesque. Palermo 1814. 55. pagini 8. pic., pp. 43-44. 
142 Una Osservazione di Nosologia vegetabile, p. 45.

143 Definizioni di 2 N. Sp. Siciliane del Genere Hesperis, pp. 46-47.

144 Economia pubblica. Quadro dello Studio metodico di questa Scienza, pp. 47-50. $50-52$.

145 Cronologia. Nuovo sistema cronologico del Sign. Ab. Mango, pp.

146 Letteratura. Seguito dei Premj decennali distribuiti dall' Instituto di Francia nel 1810, pp. 52-54.

147 Matematiche. Compendio di olcuni Saggi matematici del Sign. Dott. Carlo Hutton, pp. 54-56.

148 Fisica. Leggi generali della diffrazione della Luce del Sign. Flauguergues, traduz. dal francese Giorn. di Fisica di Luglio 1812, pp. 56-57.

149 Legislazione. Fine della Descrizione delle Carceri di Filadelfia, pp. 57-58.

150 Arti. Descrizione di una nuova macchina per fendere o spaccare i cuoj, inventata dal Sign. Giuseppe Warren Revere di Boston, pp. 58-59.

151 Chirurgia. Trattamento del Tetano del Signor Larrey, traduzione dal francese, pp. 59-60.

152 Miscellanea. Seguito del Quadro della Letteratura Siciliana nell' anno 1813 , pp. 60-62.

153 Invenzioni e Scoperte, pp. 62-64.

Volume II, Number IX, September, 1814, pp. 65-96.

154 Somiologia. Prodrono di Erpetologia Siciliana, pp. 65-67.

155 Seguito delle Osservazioni microscopiche si veda il Tom. I. num. 3, pag. 88 , pp. $68-69$.

156 Definizioni di due nuove Specie Siciliane e frutescenti del genere Brassica, pp. 69-70.

157 Analisi di un'opera francese di Storia Naturale, pp. 70-72.

158 Ottica. Abbozzo di una nuova Teoria o Classificazione dei Colori, pp. 72-74.

159 Pastorizia. Fine delle Instruzioni sopra gli Arieti Merini del Dott. D. Antonino Candela (vedasi il num. 7.), p. 75.

160 Geologia. Pensieri sopra lOreologia ossia lo Studio delle Montagne, pp. 76-78.

161 Belle-arti. Rapporti degli Ordini dell'Architettura cogli tuoni della musica del Sig. Ab. Mango, pp. 78-80.

162 Medicina. Uso interno dell' acido muriatico ossigenato traduz. compendiata dal francese delle annali di Chimica. Marzo 1810, pp. 81-82.

163 Chimica. Dellanalisi vegetale ed animale dei Sig. Gay-Lussac e Thenard, traduzione dal francese Ann. di Chimica 1810, pp. 82-84.

164 Osservazioni generali sopra gli Acidi e gli Alcali del Sign. Cav. Davy, pp. 84-85.

165 Osservazioni sopra il Zolfo ed il Fosforo, pp. 85-86. 
166 Somiologia. Scoperta di un intiero Mammonte in Siberia, pp. $86-88$.

167 Notizia di 18 nuovi generi di Piante Gramigne \& c. del Sign. Desvaux. (Bullet. philom. de 1810.), pp. 88-89.

168 Notizia di 5. N. G. di Fuci di Lamouroux, Bull. philom. 1809, p. 89 .

169 Arti. Filo di Ginestra del Sign. Giacomo Hall, pp. 89-90.

170 Scoperta delle Lime di terra cotta, pp. 90-91.

171 Miscellanea. Seguito del Quadro della Letteratura Siciliana nel 1813, pp. 91-94.

172 Notizia di alcune opere stampate in Londra in quest' anno 1814, pp. 94-95.

173 Notizia di alcune opere sopra la Sicilia ultimamente stampate in Londra, p. 95.

174 Invenzioni e Scoperte, p. 96.

Volume II, Number X, October, 1814, pp. 97-128.

175 Somiologia. Osservazioni sopra le migrazioni dei Pesci, pp. 97-100.

176 Descrizione di un Nuovo Genere di Pesce Siciliano, pp. 100-102.

177 Fine del Prodromo d'Erpetologia Siciliana, pp. 102-104.

178 Descrizione di un nuovo genere di Fungo Siciliano, p. 105.

179 Mineralogia. Notizia dei minerali e fossili delle vicinanze di Nicosia in Sicilia, pp. 105-108.

180 Archeologia. Descrizione delle Cave antiche di Nicosia, Sperlinga \&c., pp. 108-110.

181 Idrografia. Sistema della divisione dei mari del Sign. Ab. Mango, p. 110.

182 Matematiche. Analisi ragionata dell' opuscolo filosofico-analitico del Cav. Sanmartino di Catania, pp. 111-114.

183 Chimica. Osservazioni sopra la Canfora artifiziale, traduzione dal francese, pp. 114-115.

184 Scoperta di un nuovo Gaso fatta dal Sign. Giovanni Davy traduz. dal francese del Giornale di Fisica di Gennaro 1812, pp. 115-116.

185 Fisica. Congelazione dell'acqua nel vuoto del Sign. Leslie, traduzione degli annali di chimica di Maggio 1811, pp. 116-117.

186 Nuovo modo d'evaporazione nel vuoto dei Signori Clement e Desormes, pp. 118-119.

187 Medicina. Uso del sulfato di ferro nelle febbre, del Dott. Marc., p. 120 .

188 Zoologia. Quadro delle Meduse dei Sign. Peron e Lesueur, pp. $121-123$.

189 Miscellanea. Fine del Quadro della Lettêratura Siciliana nel 1813, pp. 123-126.

190 Invenzioni e Scoperte, pp. 126-127. Farmacia; Matematiche; Fisica, p. 128. Avvisi e Notizie, p. 128. 
Volume II, Number XI, November, 1814, pp. 129-160.

191 Somiologia. Osservazion sopra le specie Siciliane del genere Phoca, pp. 129-131.

192 Descrizione di due nuovi generi di Meduse Siciliane, pp. 131-132.

193 Arrivo delle Lodole vicino Palermo nell' autunno, pp. 132-134.

194 Descrizione di una nuova specie di Marrubium, pp. 134-135.

195 Osservazioni sopra il Rumex lunaria di Linneo, pp. 135-136.

196 Nuova Malattia Vegetabile, p. 136.

197 Chirurgia. Notizia dell apparato del Dott. Rosalino Giardina, per rissodare la frattura dell collo del Femore, p. 137.

198 Lettera del Medico Andrea Caudiloro ad un suo amico, sù di alcune chimiche preparazioni metalliche di grande efficacia per la cura della Gonorrea, e per chi avesse a sdegno la canizie; che ci venne data per inserirsi dall'autore, pp. 138-140.

199 Storia. Idea della Storia filosofica e politica di Sicilia dell' Avvocato D. Silvio Buccellato, pp. 140-141.

200 Archeologia. Notizia dei Monumenti inediti della collezione Recuperiana in Catania, descritti dal Possessore Barone Giuseppe Recupero in diverse memorie promulgate o da promulgarsi (comunicate dall'autore), pp. 141-142.

201 Meteorologia. Memoria ropra $i$ Venti in Sicilia, le Aure diurne, ed il Scirocco, pp. 142-146.

202 Fisica. Dell' Influenza della direzione nella propagazione del Calorico del Sign. de Sanctis, p. 147.

203 Sopra i Fenomeni che offeriscono la riflezione e la refrazione della luce, del Sign. Malus, p. 148.

204 Astronomia. Pensieri sopra le Comete \&c. di un anonimo inglese, pp. 148-149.

205 Chimica. Delle affinità chimiche, del Sign. Delametherie, pp. 150151.

206 Delle Sostanze dette semplici o elementari; dello stesso Autore, p. 151.

207 Zoologia. Caratteri delle specie di due nuovi generi di Quadrupedi fossili, Palætherium e Anoplotherium del Sign. Cuvier, pp. 151-153.

208 Quadro dei Generi di Molluschi pteropodi dei Signori Peron e Lesueur, pp. 153-155.

209 Miscellanea. Quadro della Letteratura Siciliana nel 1814, pp. $155-158$.

210 Invenzioni e Scoperte Straniere, pp. 158-160.

Volume II, Number XII, December, 1814, pp. 161-196.

211 Somiologia. Definizioni di 36 nuovi Generi di Animali marini della Sicilia, pp. 161-166.

212 Decrizione di due ambigue Produzioni marine della Sicilla, pp. $166-167$. 



\section{P RECIS}

DES DÉCOUVERTES ET TRAVAUX

\section{SOMIOLOGLQUES}

\section{DF M: C. S, RAFINESQUE-SCHMALTZ.}

entre 1800 et 1814

Qu choix raisonnét de ses principales Découvertes en Zoologie et en Botanique, pour servir d' introduction à ses ouvrages fiturs

\section{De Linne le genté at a choist pour guidea}

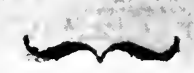

4

P A I ER M E

SOYALE TYPOGRAPHIE MILITARE. 1814,

Aas dépens de l'Autear.

No. 230. Title to Rafinesque's "Précis" 
213 Definizioni di tre N. G. di Piante marine della Sicilia, pp. 167-168.

214 Enumerazione di alcune Spugne della Sicilia, pp. 168-170.

215 Notizia di 6 nuove Specie di Piante Siciliane, pp. 170-174.

216 Idea del Panphyton Siculum di Cupani, pp. 174-175.

217 Medicina. Brevi risposte ad alcuni Quesiti medici attenenti alla Sicilia, pp. 175-177.

218 Osservazioni sopra la Vaccinazione ed il Vajuole in Palermo, pp. 177-178.

219 Statistica. Osservazioni Statistiche sopra la Città di Palermo, p. 178.

220 Astronomia. Idee sopra gii Astri e. Melcore fortuiti, p. 179.

221 Fisica. Notizia di alcuni Crepuscoli singolari, pp. 180-181.

221a Mineralogia. Osservazioni sopra le Breccie marine di Palermo, p. 181.

222 Zoologia. Compendio delle ricerche del Sig. Cuvier sopra $i$ Quadrupedi pachidermi fossili, pp. 182-183.

223 Arti. Modo di tingere $i$ legni indigeni del Sign. Cadet Gassicourt, traduz dal Francese, pp. 183-185.

224 Miscellanea. Fine del Quadro della Letteratura Siciliana nell' anno 1814, pp. 185-189.

225 Invenzinni e Scoperte Straniere, pp. 189-190.

226 Avvisi, e Notizie, pp. 190-192.

227 Prospetto di un nuovo giornale letterario, p. 192.

228 Giornale di scienze, ed arti, p. 192.

229 Indice delle materie del tomo secondo, pp. 193-196

A complete file of Specchio delle Scienze is in the Library of the Academy of Natural Sciences of Philadelphia; other copies are in the Library of Congress (vols. 1-2, numbers 1-11 only); Library of the New York Botanical Garden (vol. 1 only); Library of Gray Herbarium (numbers 3 and 4 only and in original covers); Library of Arnold Arboretum (vol. 1 only); and the Library of the Historical Society of Pennsylvania.

230 Rafinesque-Schmaltz, C. S.: | Précis | des découvertes et travaux | somiologiques | de Mr. C. S. Rafinesque-Schmaltz. | entre 1800 et 1814 | Ou choix raisonné de ses principales Découvertes | en Zoologie et en Botanique, pour servir | d' introduction à ses ouvrages | futurs |- De Linné le génie il a choisi pour

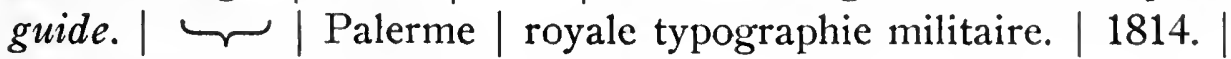
Aux dépens de l'Auteur.

Paper, $24 \mathrm{mo}$ in size, the first signature octavo and the remainder quarto in fold, pp. [1-2], 3-55, [56].

Collation: title, p. [1] ; page [2] blank; text, pp. 3-54; correction, p. 55: errata, p. [56].

See Plate VII. 
The context is in the form of a letter to C. H. Persoon.

The cover title reads:

Précis | des découvertes somiologiques | ou zoologiques et botaniques | de | C. S. Rafinesque. | $\underbrace{\sim} \mid$ Palerme $|-| 1814 . \mid$

On page 4 of the cover of parts 1 and 3 of the New Flora it is advertised for 25 cents.

Copies examined are in the Library of the Gray Herbarium; Library of the Harvard Museum of Comparative Zoölogy; Library of the Arnold Arboretum; Library of the Smithsonian Institution; Library of the New York Botanical Garden; and the Library of the U. S. Department of Agriculture.

See numbers 141 and 231.

231 Rafinesque-Schmaltz, [C. S.] Sur les Ouvrages de M. Rafinesque-Schmaltz. Desvaux's Journal de botanique, vol. IV, pp. 268-176 [276], Paris, 1814.

A reprint of the botanical portion of Précis des découvertes, preceded and followed by editorial remarks of the editor.

232 [RAFinesque, C. S.: | Collection of $\mid 29$ Plates \& 46 figures | of New Genera \& Species of | Plants | from North America. $|-|$ Discovered by C. S. Rafinesque | in 1802-4 | published in $1807,1808 \& 1814|-|$ These Plates never | published.-Only Proofs | Plates lost 1815 - thus they | are a Unique Collection. $|-|$ Deposited in the Lyceum at $\mid$ the foundation in 1817 by $\mid$ the Author - | N. B. The Phyllepidum alone was | published in the Encycl. Journal | of Sicily 1814. | ]

So runs the "made up" title of a "made up" quarto volume in the Library of the New York Botanical Garden. On plate I Rafinesque has written: "Select New Plants of N. America by C. S. Rafinesque - 1808The following Plates are the proofs of Plates lost in my Shipwreck in 1815," and on the back of the plate the "made up" title as given above, except the Italics are not indicated. So far as is known to the writer this collection is unique.

See number 11.

233 RaFinesque-Schmaltz, C. S.: | Principes fondamentaux | de $\mid$ somiologie $\mid$ ou $\mid$ les loix de la nomenclature et de la | classification de l'empire organique | ou des animaux et des végétaux | contenant les Règles essentielles de l'Art de leur / imposer des noms immuables et de les | classer méthodiquement | par C. S. Rafinesque-Schmaltz. $|-|$ Palerme $|=|$ De l'Imprimerie de Franc. Abate, | aux dépens de l'Auteur. | 1814. | 


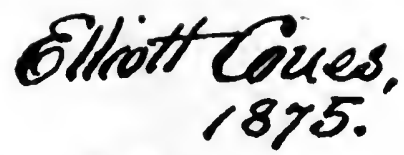

\title{
PRINCIPES FONDAMENTAUX.
}

\author{
D E \\ $60 \mathrm{M} \mathrm{IOLOGIE}$ \\ o. $\mathrm{U}$
}

LES LOIX DE LA NOMENCLATURE ET DE LA CLASSIFICATION DE L EMPIRE ORGANIQUE OU DES ANIMAUX ET DES VÉGÉTAUX contenant les Règles essentielles de l'Art de leur imposer des noms immuables et de les classer mélhodiquement

PAR C. S. RAFINESOUE-SCHMALTZ.

\section{P A E R M E}

De l'Imprinterie de Franc. Abate, aux dépens de l'Autcur.

2.8. 14.

No. 233. Title to Rafinesque's "Principes Fondamentaux" 
Paper, octavo in size, quarto in fold, pp. [1-4], 5-50, [51-52].

See Plate VIII.

The cover title reads:

Principes fondamentaux | de | somiologie | ou | les loix de la nomenclature et de la | classification des corps organisés | par C. S. Rafinesque. $|-|$ Palerme $|=|$ 1814. $\mid$

Rafinesque announces this work in Specchio delle Scienze, vol. II, p. 64.

Copies of this work are in the Library of the Gray Herbarium, Library of Harvard Museum of Comparative Zoölogy; Yale University Library; Library of Congress; Library of Harvard University; Library of the Arnold Aboretum; Library of the Smithsonian Institution; Library of the New York Botanical Garden; Library of the Office of the Surgeon-General, Library of the British Museum; Library of the U. S. Department of Agriculture; and the Fitzpatrick Collection.

234 Rafinesque-Schmaltz, C. S.: | Chloris aetnensis /o |le quattro florule dell' etna, |opuscolo | del sig. C. S. RafinesqueSchmaltz | Palermo, Dicembre 1813. | destinato per essere inserito | nella | storia naturale dell' etna, | del can. co Recupero | dal suo degno nipote | il can. co tes. re D. Agatino Recupero / di catania |

Quarto in size, folio in fold, pp. [1-2], 3-15, [16 blank].

The copies seen appear as a sort of an appendix to the close of Storia naturale e generale dell'etna del canonico Giuseppe Recupero," issued at Catania, 1815.

The copies examined are in the Boston Public Library and the Library of the Arnold Arboretum.

235 Rafinesque, C. S. : | Analyse / de la nature | ou | tableau de l'univers | et |des corps organisés |_ | par C. S. Rafinesque | De l'Institut des Sciences naturelles de Naples, et | de la Société Italienne des Sciences et des arts. |_ L L Nature est mon guide, et Linnéus mon maître. $|-|$ Palerme $|1815|-\mid$ Aux dépens de l'Auteur. |

Paper, quarto in fold, $12 \mathrm{mo}$ in size, pp. [1-4], 5-224, portrait of the author as a frontispiece.

See Plate IX.

The cover title reads:

Analyse | de la nature | ou | tableau de l'univers | et $\mid$ des corps organisés $|-|$ par C. S. Rafinesque $|-|$ Palerme $|=| 1815 . \mid$

Copies of this work are in the Library of the Gray Herbarium and the Library of Congress, the latter volume however is minus the portrait. There is a copy also in the Library of the British Museum as well as in the Library of the Historical Society of Pennsylvania. 


\section{A N A L Y S E \\ DE L I NATURP.}

- U

T A BLEAU DE L UNIVE S S

E T

DES CORPS ORGANISÊS

PAR C. S. RAFINLSQUE

De IInstitut des Scionces naturelles de Naples, de la Socicte Italieme des Sciences et rles arts.

La Nature est mon Giuda, ct limncius mon matiac.
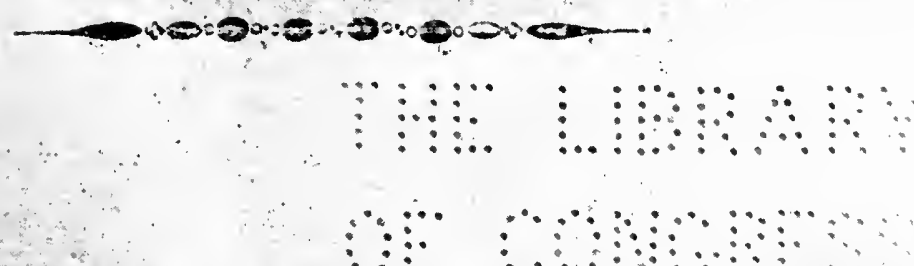

P I L L M

$$
18 \div \div
$$

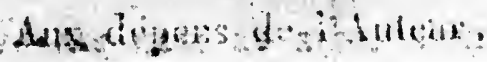

No. 235. Inner title to Rafinesque's "Analyse de la Nature" 

PLATE X

\section{GIRCULAR ADDRESS}

ON

\section{BO'TANY AND ZOOLOGY;}

SOLLOWED RT THE

PROSPECTUS OF TWO PERIODICAL WORKS;

ANNALS OF NATURE

AND SOMIOLOGY OF NORTH AMERICA.

\section{BY C. S. RAFINESQUE,}

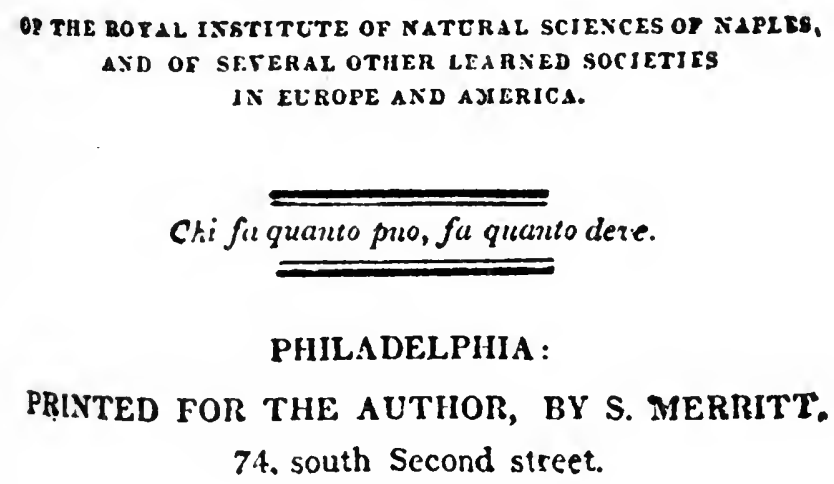

PRINTED FOR THE AUTHOR, BY S. MERRITT.

74. south Second street.

\section{6.}

No. 236. Title to Rafinesque's "Circular Address on Botany and Zoology"

236 Rafinesque, C. S. : | Circular address | on | botany and zoology; | followed by the | prospectus of two periodical works; | annals of nature | and somiology of North America. | by C. S. Rafinesque, | of the royal institute of natural sciences of Naples, | and of several other learned societies | in Europe and America. $=\mid$ Chi fa quanto puo, fa quanto deve. $|=|$ Philadelphia: 
printed for the author, by S. Merritt, $\mid 74$, south Second street. | ............ $1816 . \mid$

Pamphlet, 16mo in size, 6mo in fold, pp. [1-5], 6-36. Pages [2, 4] are blank. Some of the copies examined are only $24 \mathrm{mo}$ in size due to having been trimmed.

See Plate $\mathbf{X}$.

Also includes an annotated list of Rafinesque's published or proposed works; speaks of his shipwreck, and mentions his plans.

Three copies seen in apparently original covers contained neither title nor print on the cover pages.

Copies are in the Library of Harvard Museum of Comparative Zoölogy; Library of the State Historical Society of Wisconsin; Library of Harvard University; Library of the Arnold Arboretum; Library of the New York Botanical Garden; Library of the American Philosophical Society; Boston Public Library; Library of Boston Athenaeum; Library of Congress; Library of the British Museum; Library of the U. S. Department of Agriculture; Library of the Historical Society of Pennsylvania; and the Fitzpatrick Collection.

See numbers 312 and 313.

237 R. [AFInesque,] C. S. ART. 4. [Review of] Flora Philadelphica Prodromus, or Prodromus of the Flora Philadelphica, exhibiting a list of all the plants to be described in that work which have as yet been collected. By Dr. William P. C. Barton. Philadelphia. 1815. 4to. pp. 100. The American Monthly Magazine and Critical Review, vol. I, no. v, pp. 356-359, New York, September, 1817.

238 Rafinesque, C. S. ArT. 5. Museum of natural sciences. By C. S. Rafinesque, Esquire. 1. Description of the Tubipora Striatula, a new species of Fossil from the State of NewYork. The American Monthly Magazine and Critical Review, vol. I, no. v, pp. 359-360, New York, September, 1817.

239 [RAFInESQUE, C. S. Museum of natural sciences.] 2. Specimens of several new American species of the genus Aphis. The American Monthly Magazine and Critical Review, vol. I, no. v, pp. 360-361, New York, September, 1817.

See number 266.

240 RAFINESQUE, C. S. [Museum of natural sciences.] 3. New species of Mammifers, noticed in the Notes to the (Tableau methodique des Mammiferes) Methodical Picture of the Mammifers, by D. Desmarets, in the 24th and last volume of the French 
New Dictionary of Natural History. Paris, 1804. Translated and improved by C.S. Rafinesque. The American Monthly Magazine and Critical Review, vol. I, no. v, pp. 361-363, New York, September, 1817.

241 R.[Afinesque,] C. S. Art. 4. [Review of] A Manual of Botany for the Northern States, comprising generic descriptions of all Phenogamous and Cryptogamous plants to the north of Virginia, hitherto described, \&c. \&c. Compiled by the Editor of Richard's Botanical Dictionary. Albany. Webster \& Skinners. 1817. 12mo. pp. 164. The American Monthly Magazine and Critical Review, vol. I, no. vi, pp. 426-430, New York, October, 1817.

This is a review of the first edition of Eaton's Manual of Botany.

242 RafinesQue, C. S. ARt. 5. Museum of natural sciences. By C. S. Rafinesque, Esquire. 4. Dissertation on Water Snakes, Sea Snakes and Sea Serpents. The American Monthly Magazine and Critical Review, vol. I, no. vi, pp. 431-435, New York, October, 1817.

See number 309.

243 R. [AFINESQUE,] C. S. [Museum of natural sciences.] 5. Extracts from the Journal of Mr. Charles Le Raye, relating to some new Quadrupeds of the Missouri Region, with notes by C. S. R. The American Monthly Magazine and Critical Review, vol. I, no. vi, pp. 435-437, New York, October, 1817.

244 [RAFinesque, C. S. Museum of natural sciences.] Botany. 6. Neogenytum Siculum, or Descriptions of four new genera of Dicotyle Sicilian Plants. 'The American Monthly Magazine and Critical Review, vol. r, no. vi, pp. 437-439, New York, October, 1817.

245 [Rafinesque, C. S. Museum of natural sciences.] 7. Description of seven new Species of Sicilian Plants. The American Monthly Magazine and Critical Review, vol. I, no. vi, pp. 439440, New York, October, 1817.

246 R. [AFINESQUE,] C. S. [Museum of natural sciences.] 8. Florula of the White Mountain of Neru-Hampshire. The American Monthly Magazine and Critical Review, vol. I, no. VI, pp. 440-442, New York, October, 1817. 
247 [RAFINESQUE, C. S. Description of Glomeris eurycephalus.] The American Monthly Magazine and Critical Review, vol. I, no. vi, p. 452, New York, October, 1817.

248 Rafinesque, C. S. ART. 7. Museum of natural sciences. By C. S. Rafinesque, Esq. 9. Synopsis of four New Genera and ten new Species of Crustacea, found in the United States. The American Monthly Magazine and Critical Review, vol. II, no. I, pp. 40-43, New York, November, 1817.

249 [RAFINESQUE, C. S. Museum of natural sciences.] 10. First decade of undescribed American Plants, or Synopsis of new species, from the United States. The American Monthly Magazine and Critical Review, vol. II, no. I, pp. 43-44, New York, November, 1817.

250 [RAFInesque, C. S. Museum of natural sciences.] 11. Descriptions of seven new genera of North American Quadrupeds. The American Monthly Magazine and Critical Review, vol. II, no. I, pp. 44-46, New York, November, 1817.

251 R. [AFINESQUE,] C. S. Survey of the progress and actual state of Natural Sciences in the United States of America, from the beginning of this century to the present time. The American Monthly Magazine and Critical Review, vol. II, no. II, pp. 81-89, New York, December, 1817.

This is the leading article for the monthly issue and is considered a masterly effort. A second part was promised but apparently not published.

252 RAFInesque, C. S. ART. 5. Museum of natural sciences. By C. S. Rafinesque, esq. 12. Description of the Ioxylon Pomiferum, a new genus of North American Tree. The American Monthly Magazine and Critical Review, vol. II, no. II, pp. 118-119, New York, December, 1817.

253 [RAFinesque, C. S. Museum of natural sciences.] 13. Second Decade of undescribed American Plants. The American Monthly Magazine and Critical Review, vol. II, no. II, pp. 119-120, New York, December, 1817.

254 [RAFInESQUE, C. S. Museum of natural sciences.] 14. First Decade of new North-American Fishes. The American Monthly Magazine and Critical Review, vol. II, no. II, pp. 120-121, New York, December, 1817.

255 R.[AFInesque,] C. S. [Review of] American Entomol- 


\title{
FLORULA LUDOVICIANA ;
}

\author{
OR,
}

\section{A FLORA}

OF THE

\section{STATE OF LOUISIANA.}

\author{
$\rightarrow \infty x-\infty x-$ \\ TRANSLATED, REVISED, AND IMPROVED, \\ \ุROM THE FRENCH OF C. C. ROBIN; \\ BY C. S. RAFIN ESQUE,
}

Of the Royal Institute of Naples, the Academy of Natural Sciences of Philadelphia, the Literary and Philosophical Society of New. York, the Lyceum of Natural History of New-York, \&c. \&c. \&c. Author of the Analysis of Nature, \&c. \&c. \&c.

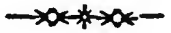

Quand Les materioux sont imparfaits, l'Élifice ne peul pas êlre complet.

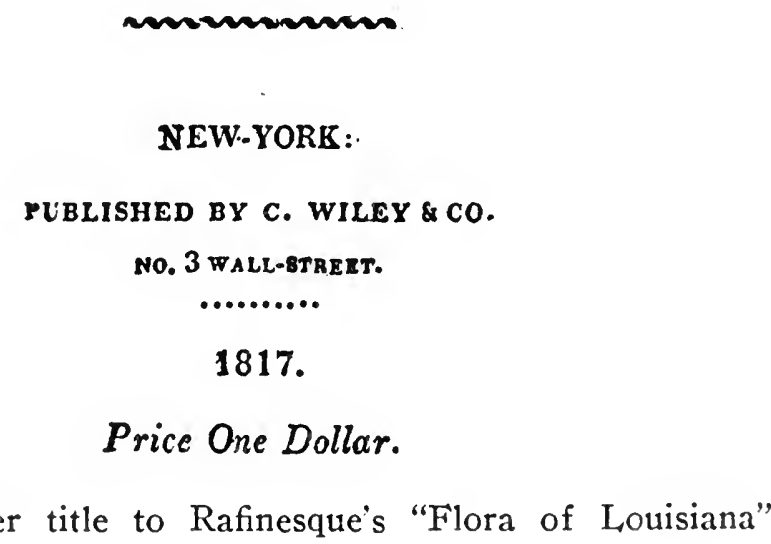

No. 257. Inner title to Rafinesque's "Flora of Louisiana" 
ogy or Descriptions of the Insects of North America, illustrated by coloured figures from drawings executed from nature, by Thomas Say. Philadelphia, Mitchell and Ames, 8vo first number pp. 40. with six plates and an engraved frontispiece. The American Monthly Magazine and Critical Review, vol. II, no. II, p. 143, New York, December, 1817.

256 R.[AFINESQUE,] C. S. [Review of] Descriptio uberior Graminum et Plantarum Calamariarum Americae septentrionalis, indigenarum et cicurum. Auctore D. Henrico Muhlenberg. Philadelphia, Sol. W. Conrad, 1817. 1 vol. 8.vo, pp. 295. The American Monthly Magazine and Critical Review, vol. II, no. II, pp. 143-144, New York, December, 1817.

257 Rafinesoue, C. S.: | Florula ludoviciana; | or, | a flora | of the $\mid$ state of Lonisiana. $|-|$ translated, revised, and improved, | from the French of C. C. Robin, | by C. S. Rafinesque, | Of the Royal Institute of Naples, the Academy of Natural Sciences of $\mid$ Philadelphia, the Literary and Philosophical Society of New- | York, the Lyceum of Natural History of New-York, | \&c. \&c. \&c. Author of the Analysis | of Nature \&c. \&c. \&c. | Quand les matériaux sont imparfaits, l'édifice ne peut pas être complet. $|-|$ New-York: | published by C. Wiley \& co. | no. 3 wall-street. | ......... | 1817. | Price One Dollar. |

Paper, $16 \mathrm{mo}$ in size, $6 \mathrm{mo}$ in fold, pp. [1-7], 8-178.

See Plate XI.

The cover title reads:

Florula ludoviciana. | - | flora | of | Louisiana. | by | Robin and Rafinesque. | with a | supplement and appendix. | by |C. S. Rafinesque. | $\mid$ New-York: | published by C. Wiley \& co. | no. 3, wall-street. | | 1817. |

The volume "is respectfully inscribed to Dewitt Clinton, LL. D. Governor of the State of New-York," etc.

Copies of Florula Ludoviciana are in the Library of the Gray Herbarium; Library of the Arnold Arboretum; Yale University Library; Library of the State Historical Society of Wisconsin; Library of the Missouri Botanical Garden; Library of the American Philosophical Society; The New York Public Library; Library of Harvard University; Library of the Smithsonian Institution; Library of Congress; Library of the U. S. Department of Agriculture; Library of the Historical Society of Pennsylvania; Library of the British Museum; and the Fitzpatrick Collection.

This publication is referred to in The American Monthly Magazine and Critical Review, vol. 1, p. 453, New York, October, 1817, and is briefly re- 
viewed in vol. II of the same Journal, p. 366, presumably by Dr. Samuel L. Mitchill.

258 R. [AFInESQue,] C. S. ART. 2. [Review of] Flora Americae Septentrionalis, or a systematic arrangement and description of the Plants of North America, \&c. By Frederick Pursh, 2 vols. 8vo. with 24 Engravings. London, 1814. The American Monthly Magazine and Critical Review, vol. II, no. III, pp. 170-176, New York, January, 1818.

The first installment of an extensive review. See number 264.

259 Rafinesque, C. S. ART. 6. Museum of natural sciences. By C. S. RAFinesQue, EsQ. 15. Introduction to the Ichthyology of the United States. The American Monthly Magazine and Critical Review, vol. II, no. III, pp. 202-203, New York, January, 1818.

260 [RAFinesque, C. S. Museum of natural history.] 16. Descriptions of two new genera of North-American Fishes, Opsanus and Notropis. The American Monthly Magazine and Critical Review, vol. II, no. III, pp. 203-204, New York, January, 1818.

261 [RAFINESQUE, C. S. Museum of natural history.] 17. Second Decade of new North-American Fishes. The American Monthly Magazine and Critical Review, vol. II, no. III, pp. 204 206, New York, January, 1818.

262 [RAFinesque, C. S. Museum of natural history.] 18. Third Decade of new Species of North American Plants. The American Monthly Magazine and Critical Review, vol. II, no. III, pp. 206-207, New York, January, 1818.

263 Rafinesque, C. S. Phycis Marginatus, Rafin. The American Monthly Magazine and Critical Review, vol. II, no. IV, pp. 243-244, New York, February, 1818.

Gives cut illustrating this species of fish.

264 R. [Afinesque,] C. S. Art. 3. [Review of] Flora Americæ Septentrionalis, or a systematic arrangement and description of the Plants of North America, \&c. By Frederick Pursh, 2 vols. 8vo, with 24 Engravings. London, 1814, 1814. The American Monthly Magazine and Critical Review, vol. II, no. Iv, pp. 265-269, February, 1818.

This is the continuation and conclusion of the article with the same title mentioned above. See number 258. 
265 R.[AFInesque,] C. S. AR'T. 3. [Review of] Florula Bostoniensis. A Collection of Plants of Boston and its environs, with their generic and specific characters, synonymes, descriptions, place of growth, and time of flowering, and occasional remarks. By Jacob Bigelow, M. D. Boston, 1814. 8vo. pp. 280. The American Monthly Magazine and Critical Review, vol. II, no. v, pp. 342-344, New York, March, 1818.

266 Rafinesque, C. S. Second Memoir on the Gemus Aphis, containing the Description of 24 new American Species. By C.S. Rafinesque. The American. Monthly Magazine and Critical Review, vol. III, no. I, pp. 15-18, New York, May, 1818.

See number 239.

267 R. [afinesque,] C. S. ART. 3. [Review of] A Sketch of the Botany of South-Carolina and Georgia. By Stephen Elliott, Esq. \&c. \&c. Charleston, 1817. 5 Numbers, 8vo, each of 100 pages, with some plates; to be continued. The American Monthly Magazine and Critical Review, vol. III, no. II, pp. 96-101, New York, June, 1818.

268 R.[afinesque,] C. S. ArT. 4. [Review of] An Index to the Geology of the Northern States, with a transverse Section from the Catskill Mountains to the Atlantic. Prepared for the Geological Classes at William's College, Massachusetts. By Amos Eaton, A. M. \&c. \&c. 8vo, pp. 52. Leicester, 1818. The American Monthly Magazine and Critical Review, vol. III, no. III, pp. 175-178, New York, July, 1818.

269 R. [AFInESQUe,] C. S. ART. 4. [Review of] Journal of the Academy of Natural Sciences of Philadelphia. Vol. i. Part I. Philadelphia. 8vo. pp. 220, and 9 plates. May to December, 1817. The American Monthly Magazine and Critical Review, vol. III, no. Iv, pp. 269-274, New York, August, 1818.

270 RaFinesque, C. S. ART. 3. Museum of natural history. Discoveries in Natural History, made during a Journey through the Western Region of the United States, by Constantine Samuel Rafinesque, Esq. Addressed to Samuel L. Mitchill, President, and the other Members of the Lyceum of Natural History, in a letter dated at Louisville, Falls of Ohio, 20th July, 1818. The American 
Monthly Magazine and Critical Review, vol. III, no. v, pp. 354-356, September, 1818.

See numbers 271, 272, and 274 .

271 Rafinesque, Constantine Samueit. Art. 4. Museum of natural history. Further Discoveries in Natural History, made during a Journey through the Western Region of the United States. By Constantine Samuel Rafinesque, Esq. The American Monthly Magazine and Critical Review, vol. III, no. vi, pp. 445447, New York, October, 1818.

See numbers 270,272 , and 274 .

272 Rafinesque, C. S. ART. 5. Museum of natural history. Farther Account of Discoveries in Natural History, in the Western States, by Constantine Samuel Rafinesque, Esq. communicated in a Letter from that Gentleman to the Editor. The American Monthly Magazine and Critical Review, vol. Iv, no. I, pp. 39-42, New York, November, 1818.

Dated "Lexington, Oct. 5, 1818."

See numbers 270, 271, and 274 .

273 RaFinesque, C. S. Description of three new genera of fluviatile Fish, Pomoxis, Sarchirus and Exoglossum. By C. S. Rafinesque. Read December 1st and 8th. Journal of the Academy of Natural Sciences of Philadelphia, vol. I, part II, pp. 417422, November, 1818.

Plate xvII gives figures illustrating four of the species described in the article.

274 RafineSQue, C. S. ART. 3. Museum of natural history. General Account of the Discoveries made in the Zoology of the Western States. By C. S. Rafinesque, in 1818. The American Monthly Magazine and Critical Review, vol. Iv, no. II, pp. 106107, New York, December, 1818.

See numbers 270, 271, and 272.

275 Rafinesque, C. S. ART. XVI. A Journal of the Progress of Vegetation near Philadelphia, between the 20th of February and the 20th of May, 1816, with occasional Zoological Remarks. By C. S. Rafinesque. The American Journal of Science, vol. I, no. 1, pp. 77-82, New York, 1818.

276 RafinesQue, C. S. ART. XVII. Description of a Nerw 
Species of North American Marten, (Mustela vulpina,) by C. S. Rafinesque. The American Journal of Science, vol. I, no. 1, pp. 82-84, New York, 1818.

See number 299.

277 RaFinesque, C. S. ART. XVIII. Natural History of the Scytalus Cupreus, or Copper-head Snake. By C. S. Rafinesque. The American Journal of Science, vol. I, no. 1, pp. 84-86, New York, 1818.

278 RAFinesque, C. S. ART. XI. Descriptions of species of Sponges observed on the shores of Long-Island. By C. S. Rafinesque, Esq. The American Journal of Science, vol. I, no. 2, pp. 149-151, New York, 1818.

279 RAFINESQUe, C. S. ART. XII. Memoir on the Xanthium maculatum, a New Species from the State of New-York, \& c. by C. S. Rafinesque, Esq. The American Journal of Science, vol. I, no. 2, pp. 151-153, New York, 1818.

280 Rafinesque, C. S. ART. XIV. Description of a New Genus of North American Fresh-water Fish, Exoglossum, by C. S. Rafinesque, Eso. The American Journal of Science, vol. I, no. 2, pp. 155-156, New York, 1818.

281. Rafinesque, C. S. ART. VIII. Description of a New Genus of American Grass. Diplocea Barbata, by C. S. Rafinesque, Esq. The American Journal of Science, vol. I, no. 3, pp. 252-254, New York, 1818.

282 Rafinesque, C. S. Esq. [Announcement of "Travels and Discoveries in the West" to be published by Cramer and Spear of Pittsburg.] The American Journal of Science, vol. I, no. 3, p. 311, New York, 1818.

283 Rafinesque, C. S. Prodrome De 70 nouveaux Genres d'Animaux découverts dans l'intérieur des Etats-Unis d'Amérique, durant l'année 1818; Par C. S. Rafinesque, Professeur de Botanique ed d'Histoire naturelle dans l'Université de Lexington en Kentucky. Journal de Physique, de Chemie et D'Histoire Naturelle, et des Arts, tome LxxxviII, pp. 417-429, Paris, Juin an 1819.

The article consists of seventy numbered paragraphs.

284 Rafinesque, C. S. ArT. VIII. Description and Natural Classification of the Genus Floerkea, by C. S. Rafinesque. 
The American Journal of Science, vol. I, no. 4, pp. 373-376, New York, 1819.

The title page of volume I of The American Journal of Science gives the year of publication as 1818. Many of the articles in the latter portion of the volume however are dated "1819."

285 RAFIneSQUe, C. S. ART. IX. Descriptions of Three New Genera of Plants, from the State of New-York. Cylactis, Nemopanthus, and Polanisia, by C. S. Rafinesque. The American Journal of Science, vol. I, no. 4, pp. 377-379, New York, 1819.

286 RAFIneSQUE, C. S. ART. X. Notice on the Myosurus Shortii. The American Journal of Science, vol. I, no. 4, pp. 379380, New York, 1819.

287 RaFinesque, C. S. ART. XIV. Thoughts on Atmospheric Dust. By C. S. Rafinesque, Esq. The American Journal of Science, vol. I, no. 4, pp. 397-400, New York, 1819.

288 R. [AFINESQUE,] C. S. ART. 3. [Review of] The Genera of North-American Plants and a Catalogue of the Species to the year 1817. By Thomas Nuttall, F. L. S. \&c. \&c. 2 vols. $12 \mathrm{mo}$. Philadelphia. 1818. The American Monthly Magazine and Critical Review, vol. Iv, no. III, pp. 184-196, New York, January, 1819.

289 RaFinesQue, C. S. ART. 5. Museum of natural history. Result of the Botanical Discoveries made in the Western States by C.S. Rafinesque. The American Monthly Magazine and Critical Review, vol. IV, no. III, pp. 207-208, New York, January, 1819.

290 RaFinesQue, C. S. ART. 3. Museum of natural history. Description of a new Genus of Fluviatile Bivalve Shell, of the family of Brachiopodes; Notrema Fissurella; in a Letter to Dr. S. L. Mitchill, Prof. of Nat. Hist. \&c. New-York. The American Monthly Magazine and Critical Review, vol. Iv, no. v, p. 356, New York, March, 1819.

291 RAFInESQUe, C. S. On some New Genera of American Plants. Extract of the third Letter of $\mathrm{C}$. S. Rafinesque, to $\mathrm{Mr}$. Decandolle, Professor of Botany at Ginevra, and author of the new Species Plantarum, dated Philadelphia, 25th Feb. 1819. Translated from the French. The American Monthly Magazine and Critical Review, vol. Iv, no. v, pp. 356-358, New York, March, 1819. 
292. RAFINESQUE, C. S. On the introduction and cultivation of the Tea-Plant, in three Letters from C. S. Rafinesque, Esq. to the Hon. S. L. Mitchill. Read before the Lyceum of Natural History, Feb. 8, 1819. Letter I. The American Monthly Magazine and Critical Review, vol. Iv, no. v, pp. 382-383, New York, March, 1819.

The communication is dated: "Philadelphia, 5th Feb. 1819."

See numbers 293 and 294.

293 RAFINESQUE, C. S. Letter II. On the several species of Tea, their Discriminating Characters, and their Places of Growth. The American Monthly Magazine and Critical Review, vol. Iv, no. v, pp. 383-384, New York, March, 1819.

This communication is dated: "Philadelphia 7th Feb. 1819."

See numbers 292 and 294.

294 RaFinesque, C. S. Letter III. To Dr. Samuel L. Mitchill, on the Cultivation of Tea in the United States. The American Monthly Magazine and Critical Review, vol. Iv, no. v, p. 384, New York, March, 1819.

This communication is dated: "New York, 20th Feb. 1819."

See numbers 292 and 293.

295 RAFINESQUE, C. S. ART. 7. Letter to the Editor of the American Monthly Magazine, on the Date-Tree, or Palm. By C. S. Rafinesque. The American Monthly Magazine and Critical Review, vol. Iv, no. vi, pp. 465-467, New York, April, 1819.

This contribution is dated: "Philad. 15th Feb. 1819."

296 [RAFinesque, C. S.] Icthyology [of Louisville, Kentucky]. Sketches of Louisville And its Environs by H. M'Murtrie, first edition, Louisville, 1819, pp. 62-64.

This is an article contributed to by C. S. Rafinesque. There was no subsequent edition of M'Murtrie's Sketches of Louisville.

In the introduction occurs the following statement "To the politeness of that accomplished and skilful naturalist Mr. Rafinesque, I am indebted for a considerable portion of the following catalogues."

297 [RAFINESQUE, C. S.] Conchology [of Louisville, Kentucky]. Sketches of Louisville And its Environs by H. M'Murtrie, first edition, Louisville, 1819, pp. 65-66.

An article contributed to by C. S. Rafinesque.

298 [RAFinesque, C. S.] Florula Louisvillensis, | sive | 
Plantarum Catalogus, | vicinitate urbis. $|=|$ Henrico M'Murtrie, M. D. \&c. $|=|$ MDCcCxIx. $\mid$

Octavo in size, quarto in fold, pp. [207-211], 212-230.

The copy seen in the John Crerar Library is an excerpt from Henry M'Murtrie's "Sketches of Louisville and its Environs", edition 1819. This Florula is said to have been prepared by or at least contributed to by Rafinesque. The copy, in the Library of the State Historical Society of Wisconsin and also the one in the possession of the writer, of the "Sketches of Louisville and its Environs; including, among a great variety of miscellaneous matter, a Florula Louisvillensis; etc., by H. M'Murtrie," gives the above title and pagination in the body of the work.

See Western Review and Miscellaneous Magazine, Vol. II, p. 90.

299 Rafinesque, C. S. LXVII. Description of a nere Species of North American Marten (Mustela vulpina). The Philosophical Magazine and Journal, by Alexander Tilloch, vol. LiII, no. 254, pp. 411-412, London, June, 1819.

See number 276.

300 Rafinesgue, C. S. Prodrome Des nouveaux Genres de Plantes observés en 1817 et 1818 dans l'intérieur des Etats-Unis d'Amérique. Par C. S. Rafinesque, Professeur de Botanique et d'Histoire naturelle dans l'Université de Lexington. Journal de Physique, de Chenie et D'Histoire Naturelle, et des Arts, vol. LXxxix, pp. 96-107, Paris, August, 1819.

This contribution is dated Philadelphia, May 1, 1819. Fifty genera are described.

Asa Gray states that this is probably Rafinesque's most creditable production. $-A m$. Jr. Sc. $40: 234$.

See number 338.

301 Rafinesque, C. S. Descriptions De onze Genres nouveaux de Mollusques, publies en 1814. Journal de Physique, de Chemie et D'Histoire Naturelle, et des Arts, tome 89, p. 150, Paris, 1819.

See number 339.

302 RAFINESQUE, C. S. On the different Lightnings observed in the western states, by C.S. Rafinesque, Professor of Botany and Natural History in Transylvania University. The Western Review and Miscellaneous Magazine, vol. I, no. I, pp. 60-62, Lexington, August, 1819.

A popular account of the lightning with descriptions of the various 
shapes which the flash may assume. This article is the basis of the gross calumny inflicted upon Rafinesque by various writers. They only discredit themselves who charge that Rafinesque deliberately described twelve new species of thunder and lightning.

This Western Review was edited by William Gibbs Hunt, a graduate of Harvard College. It was a monthly filled with dissertations of the ultra-conservative type, and existed only two years. The issues are: vol. I, nos. 1-6, August, 1819, to January, 1820 ; vol. 2, nos. 1-6, February to July, 1820 ; vol. 3 , nos. $1-6$, August, 1820 , to January, 1821 ; and vol. 4 , nos. $1-6$, February to July, 1821.

A file may be found in the Library of the State Historical Society of Wisconsin and the Library of Congress.

303 Rafinesque, C. S. Miscellany. Botany of Kentucky. On its principal features, by C. S. Rafinesque, Professor of Botany and Natural History in Transylvania University. The Western Review and Miscellaneous Magazine, vol. r, no. 2, pp. 92-95, Lexington, September, 1819.

In the same number on page 128, a number of typographical errors in this article are noted and corrected.

304 RAFinesque, C. S. Veterinary. On the Salivation of horses.-C. S. Rafinesque. The Western Review and Miscellaneous Magazine, vol. I, no. 3, pp. 182-184, Lexington, October, 1819.

States that the salivation of horses is caused by eating Euphorbia hypericifolia and Lobelia inflata. Suggests preventives and a probable cure.

305 RAFinesque, C. S. Remarques critiques et synonymiques sur les Ouvrages de MM. Pursh, Nuttall, Elliott, Jorrey, ['Torrey], Barton, Muhlenburg, etc., sur les Plantes des Etats Unis. Journal de Physique, de Chemie et D'Histoire Naturelle, et des Arts. vol. Lxxxıx, pp. 256-261, Paris, October, 1819.

This contribution is dated Philadelphia May 1, 1819. It includes ninety items.

306 Rafinesque, C. S. Agriculture. On the oil of pumpkin seeds. To Dr. C. L. Seeger, Northampton, (Mass.) The Western Review and Miscellaneous Magazine, vol. I, no. 3, pp. 185-186, Lexington, October, 1819.

307 Rafinesque, C. S. Botany. Descriptions of two new Shrubs from Kentucky, \&c. by C. S. Rafinesque, Professor of Botany, \&c. in Transylvania University. The Western Review and 
Miscellaneous Magazine, vol. I, no. 4, pp. 228-230, Lexington, November, 1819.

Describes Betula rupestris, rock birch; and Cornus obliqua, obliqual dogwood.

308 Rafinesque, C. S. Natural History. Description of two species of foxes from the western states; by C. S. RAFINESQUE. The Western Review and Miscellaneous Magazine, vol. I, no. 4, pp. 234-236, Lexington, November, 1819.

Describes Canis melanurus, black-tail fox; and Canis leucurus, whitetail fox.

309 Rafinesque, C. S. Dissertation on Water Snakes, Sea Snakes, and Sea Serpents. The Philosophical Magazine and Journal by Alexander Tilloch, vol. LIv, no. 259, pp. 361-367, London, November, 1819.

The above is said to have been published also in the London Literary Gazette, 1819.

See number 242 .

310 RAFINESQUE, C. S. Natural history of the fishes of the Ohio river and its tributary streams, by C. S. Rafinesque, Professor of Botany and Natural History in Transylvania University. Introduction. The Western Review and Miscellaneous Magazine, vol. I, no. 5, pp. 305-313, Lexington, December, 1819.

Contains general remarks on American Ichthyology and a description of the Ohio river and its basin. This is the introductory article to Ichthyologia Ohiensis.

See number 314 .

See also numbers $316,320,322,323,325,329,334,335,337$, and 937.

311 RAFINESQUE, C. S. On a remarkable ancient monument near Lexington.-By C. S. Rafinesque. The Western Review and Miscellaneous Magazine, vol. I, no. 5, pp. 313-314, Lexington, December, 1819.

Describes a circumvallation of earth situated near Lexington, also gives a rough classification of tumuli. A more accurate description was given later. See number 324 .

312 RAFinesQue, C. S. Litterarische Nachrichten. Circular address on Botany and Zoology ; Followed by the Prospectus of two Periodical works; Annals of Nature and somiology of North America. By C. S. Rafinesque, of the Royal Institute of Natural 
sciences of Naples, and of several other learned societies in Europe and America. Litterarischer Anzeiger, Nr. xv, pp. 57-60, 1819.

See number 236.

313 [RAFinesque, C. S. Prospectus of] Somiology of North America, including the Flora and Fauna, or the Botany and Zoology of the United States of America and the Adjacent Countries. (Zele et Perseverance.) Litterarischer Anzeiger, Nr. XvI, pp. 61-64, 1819.

The note at the close of the article added by the editor says: "Dieser Mann kann mehr als Brod essen. So weit hat es Trattinnick noch lange nicht gebracht."

See number 236.

314 RAFinesque, C. S. Description of the river Ohio, by C. S. Rafinesque, Professor of Botany and Natural History in Transylvania University. The Western Review and Miscellaneous Magazine, vol. I, no. 6, pp. 361-377, Lexington, January, 1820.

On page 368 the "Fishes of the Ohio, first part, Thoracic fishes" begins. Species numbers 1-9.

The continuation of the introductory article to Ichthyologia Ohiensis.

See number 310 .

See also numbers $316,320,322,323,325,329,334,335,337$, and 937.

315 RAFInESQUE, C. S. La divinite. Ode sacree, a echo et chorus responsif. (The Divinity. A Sacred Ode with responsive Echo.) The Western Review and Miscellaneous Magazine, vol. I, no. 6, pp. 383-384, Lexington, January, 1820.

A French poem in six stanzas of four lines each. Signed: Transylvania University, January 1st, 1820.

316 RAFInesque, C. S. Fishes of the river Ohio, by C. S. Rafinesque, Professor of Botany and Natural History in Transylvania University. The Western Review and Miscellaneous Magazine, vol. II, no. 1, pp. 49-57, Lexington, February, 1820.

Describes species numbers 10-22.

See numbers 310, 314, 320, 322, 323, 325, 329, 334, 335, 337, and 937.

317 Rafinesoue, Professor [C. S.] Monthly results of meteorological observations, Made in Lexington by Professor Rafinesque. The Western Review and Miscellaneous Magazine, vol. II, no. 1, pp. 57-58, Lexington, February, 1820.

Gives the results for January, 1820 , in a very creditable manner. 
318 RAFInESQUe, PROFESSOR [C. S.] Monthly results of meteorological observations, Made in Lexington by Professor Rafinesque. The Western Review and Miscellaneous Magazine, vol. II, no. 2, pp. 122-123, Lexington, March, 1820.

Gives "No. 2. Results for February, 1820," with a floral and a faunal note.

319 R.[AFINESQUe], C. S. Fragments d'un poeme sur la femme. (Fragments of a Poem on Woman.) The Western Review and Miscellaneous Magazine, vol. II, no. 2, pp. 127-128, Lexington, March, 1820.

A poem of forty-two lines.

320 Rafinesque, C. S. Fishes of the river Ohio, by C. S. Rafinesque, Professor of Botany and Natural History in Transylvania University. The Western Review and Miscellaneous Magazine, vol. Ir, no. 3, pp. 169-177, Lexington, April, 1820.

Describes species numbers 23-34.

See numbers 310, 314, 316, 322, 323, 325, 329, 334, 335, 337, and 937.

321 Rafinesque, Professor [C. S.] Monthly results of meteorological observations, Made in Lexington by Professor Rafinesque. The Western Review and Miscellaneous Magazine, vol. II, no. 3, pp. 185-186, Lexington, April, 1820.

Contains "No. 3. Results for March 1820," with phænological notes on the vegetation and a faunal note.

322 RAFINESQUe, C. S. ART. IV. Description of the Silures or Catfishes of the River Ohio. By C. S. Rafinesque, Professor of Botany and Natural History in the Transylvania University of Lexington, in Kentucky. [Communicated by the Author.] The Quarterly Journal of Science, Literature, and the Arts, The Royal Institution of Great Britain, vol. Ix, pp. 48-52, London, April, 1820.

This contribution is dated and signed at the end: "Transylvania University, 1st October, 1819. C. R. [S.] Rafinesque."

The brackets occur in the original title.

323 RaFinesque, C. S. Fishes of the river Ohio, by C. S. Rafinesque, Professor of Botany and Natural History in Transylvania University. The Western Review and Miscellaneous Magazine, vol. II, no. 4, pp. 235-242, Lexington, May, 1820. 
Describes species numbers $35-51$.

See numbers 310, 314, 316, 320, 322, 325, 329, 334, 335, 337, and 937.

324 RAFINESQUE, C. S. Description of the ancient town near Lexington, By C. S. Rafinesque, Prof. of Bot. and Nat. History, in a letter to Caleb Atwater, of Circleville, Ohio. The Western Review and Miscellaneous Magazine, vol. II, no. 4, pp. 242-244, Lexington, May, 1820.

The letter is dated "Lexington, 25th April, 1820." Describes more accurately the circumvallation near Lexington. See number 311 .

325 Rafinesque, C. S. Fishes of the river Ohio, by C. S. Rafinesque, Professor of Botany and Natural History in Transylvania University. The Western Review and Miscellaneous Magazine, vol. II, no. 5, pp. 299-307, Lexington, June, 1820.

Describes species numbers 52-67.

See numbers 310, 314, 316, 320, 322, 323, 329, 334, 335, 337, and 937.

326 Rafinesque, Professor [C. S.] Monthly results of meteorological observations, Made in Lexington by Professor Rafinesque. The Western Review and Miscellaneous Magazine, vol. II, no. 5, pp. 310-312, Lexington, June, 1820.

Gives "No. 4. Results for April, 1820. No. 5. Results for May 1820," with phænological notes of the vegetation and a faunal note.

327 RAFINESQUE, C. S. Remarks on the geology of the valley of the Mississippi. No. II. The Western Review and Miscellaneous Magazine, vol. II, no. 6, pp. [321]-322, Lexington, July; 1820 .

Remarks mainly on the late John D. Clifford. This contribution is the leading article.

328 RAFINESQUE, C. S. [Note on Discomphites magna] The Western Review and Miscellaneous Magazine, vol. II, no. 6, p. 326, Lexington, July, 1820.

329 RAFinesque, C. S. Fishes of the river Ohio, by C. S. Rafinesque, Professor of Botany and Natural History in Transylvania University'. The Western Review and Miscellaneous Magazine, vol. II, no. 6, pp. 355-363, Lexington, July, 1820.

Describes species numbers $68-82$.

See numbers 310, 314, 316, 320, 322, 323, 325, 334, 335, 337, and 937.

330 Rafinesque, Professor [C. S.] Monthly results of meteorological observations, Made in Lexington by Professor Rafi- 
nesque. The Western Review and Miscellaneous Magazine, vol. II, no. 6, pp. 374-375, Lexington, July, 1820.

Gives "No. 6. Results for June, 1820," with phænological notes of the vegetation and a short faunal note.

331 Rafinesque, C. S. Letter to Caleb Atwater, of Circleville, On the Upper Alleghawian Monuments of North Elkhorn Creek, Fayette County, Kentucky. Lexington, 12th July, 1820. The Western Review and Miscellaneous Magazine, vol. III, no. 1, pp. 53-57, Lexington, August, 1820.

332 Rafinesque, Professor C. S. Astronomy. Enquiries on the galaxy or milky-way. The Western Review and Miscellaneous Magazine, vol. III, no. 2, pp. 117-124, Lexington, September, 1820.

333 Rafinesque, Professor [C. S.] Monthly results of meteorological observations Made in Lexington by Professor Rafinesque. The Western Review and Miscellaneous Magazine, vol. III, no. 2, pp. 124-127, Lexington, September, 1820.

Gives "No. 7. Results for July 1820. No. 8. Results for August 1820. No. 9 Results for September 1820," along with phænological notes of the vegetation and a faunal note.

334 RAFInESQUe, C. S. Fishes of the river Ohio, by C. S. Rafinesque, Professor of Botany and Natural History in Transylvania University. The Western Review and Miscellaneous Magazine, vol. III, no. 3, pp. 165-173, Lexington, October, 1820.

Describes species numbers 83-91.

See numbers 310,314, 316, 320, 322, 323, 325, 329, 335, 337, and 937.

335 RAFINESQUE, C. S. Fishes of the river Ohio, by C. S. Rafinesque, Professor of Botany and Natural History in Transylvania University. The Western Review and Miscellaneous Magazine, vol. III, no. 4, pp. 244-252, Lexington, November, 1820.

Contairs "third part.-Apodial fishes," species numbers 92-95; "fourth part.-Atelosian fishes," species numbers 96-104.

See numbers $310,314,316,320,322,323,325,329,334,337$, and 937 .

336 [Rafinesque, C. S.] Western Minerva; | or, | American Annals of Knowledge | and Literature; | a quarterly journal to be published in $\mid$ Lexington Kentucky. $|=|$ un peu de tout. $\mid$ $=\mid$ prospectus. | Kentucky Gazette, new series, vol. 6, no. 49, 
p. [1], column [3], Lexington, December 7, 1820. [Old series, vol. Xxxiv.]

The same is in vol. 6 , No. 50, p. [4], colunir [1], December 14, 1820; and vol. 6, no. 50, p. [1], column [4], December 21, 1820. The issue for December 28, 1820, has not been seen.

See numbers $342,375,431$, and 432 .

337 RAFINESQUE, C. S. : Ichthyologia Ohiensis, | or | natural history $\mid$ of $\mid$ the fishes inhabiting the | river Ohio | and its tributary streams, | Preceded by a physical description of the Ohio and its branches. $|=|$ By C. S. Rafinesque, | Professor of Botany and Natural History in Transylvania University, Au- | thor of the Analysis of Nature, \&c. \&c. Member of the Literary and | Philosophical Society of New-York, the Historical Society of NewYork, | the Lyceum of Natural History of New York, the Academy of Natural | Sciences of Philadelphia, the American Antiquarian Society, the Royal | Institute of Natural Sciences of Naples, the Italian Society of Arts and | Sciences, the Medical Societies of Lexington and Cincinnati, \&c. \&c $=\mid$ The art of seeing well, or of noticing and distinguishing with accuracy | the objects which we perceive, is a high faculty of the mind, unfolded in few individuals, and despised by those who can neither acquire it, nor appreciate | its results. | - Lexington, Kentucky: | printed for the author by W. G. Hunt. (price one dollar.) $|-| 1820 . \mid$

Octavo in size, quarto in fold, pp. [i-ii, 5], 6-90. The sixth line is in reversed italics.

See Plate XII.

The copy in the Newberry Library of Chicago has the original pale green wrappers and shows neither title nor printed matter on any of the cover pages.

Copies of this work are in the Library of Harvard Museum of Comparative Zoölogy; The Newberry Library; Library of the Academy of Natural Sciences of Philadelphia; Boston Athaeneum; Library of Congress; Library of the Smithsonian Institution; Library of Harvard University; The New York Public Library; Yale University Library; Library of the British Museum; Library of the Historical Society of Pennsylvania; Library of the Historical and Philosophical Society of Ohio; and the Library of the U. S. Bureau of Fisheries.

A copy is in the possession of Charles Scribner's Sons [The Heckscher copy] and two or three copies have been on the market in late years, destination unknown to the writer. 


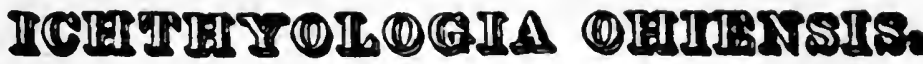

OR

\author{
NATURAL HISTORY
}

OF

\section{THE FISHES INHABITING THE}

\section{RIVER OHIO}

\section{AND ITS TRIBUTARY STREAMS,}

Preceded by a physical description of the Ohio and.its branchcs.

\section{BY·C. S. RAFINESQUE,}

Professor of Botany and Natural History in Transylvaniz University, Author of the Analysis of Nature, \&c. \&c. Member of the Literary and Philosophical Socieiy of New-York, the Historical Society of New-York, the Lyceum of Natural History of New York, the Academy of Natural Sciences of Philadelphia, the American Antiquarian Society, the Royal Institute of Natural Sciences of Naples, the Italian Society of Arts and Sciences, the Medical Societies of Lexington and Cincinnati, \&c. \& c

The art of seeing well, or of noticing and distinguishing wath accuracy the objects which we perceive, is a high faculty of the mind, unfolded in fero individuals, and despised by those who can neither acgure it, nor appreciate its results.

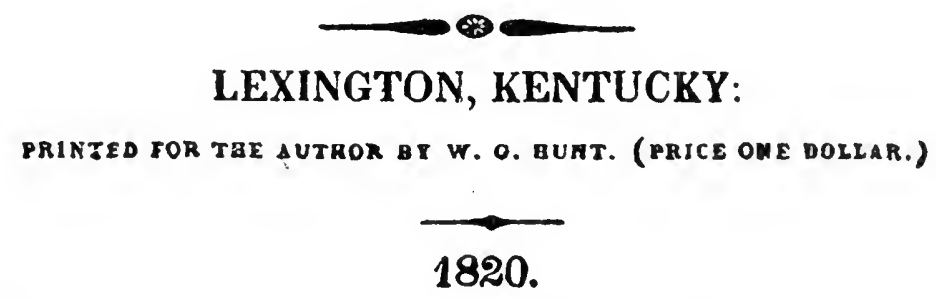

No. 337. Title to Rafinesque's "Ichthyologia Ohiensis" 
See number 937.

See also numbers $310,314,316,320,322,323,325,329,334$, and 335 .

338 Rafinesque, C. S. Prodrome Des nouveaux Genres de Plantes observés en 1817 et 1818 dans l'intérieur des Etats-Unis d'Amérique; Par C. S. Rafinesque, Professeur de Botanique et d'Histoire naturelle dans l'Université de Lexington. Litterarischer Anzeiger, pp. 236-244, Jena, 1820. 300.

This contribution is dated "Philadelphie le 1. mai 1819." See number

339 [Rafinesque, C. S.] Rafinesque, Professor der Botanik und Naturgeschichte auf der Universität zu Lexington Ueber eilf neue Sippen von Mollusken, aufgestellt 1814. Litterarischer Anzeiger, pp. 244-247, Jena, 1820.

See number 301.

340 Rafinesque, C. S. Prodrome d'une monographie des rosiers de l'Amérique septentrionale, contenant la description de quinze nouvelles espèces et vingt variétés. Par M. C. S. Rafinesque, Professeur de botanique et d'hist. nat. dans l'Université Transylvane de Lexington en Kentuky, et membre de plusieurs sociétés savantes d'Europe et d'Amérique, etc. Annales Générales des Sciences Physiques, tome cinquième, pp. 210-220, Bruxelles, 1820.

See number 362.

341 RAFinesque, C. S. Sur le genre Houstonia et description de plusieurs espèces nouvelles, etc. Annales Générales des Sciences Physiques, tome cinquième, pp. 224-227, Bruxelles, 1820.

See number 362.

342 RAFinesque, C. S. The Western Minerva, or American Annals of Knowledge and Literature; a Quarterly Journal to be published in Lexington, Kentucky. Un peu de tout. Prospectus. Kentucky Reporter, Lexington, October 16, 1820.

A prospectus of the proposed establishment of a journal, only one number of which is said to have been published. This prospectus doubtless ran through a number of later issues of the Kentucky Reporter.

See numbers $336,375,431$, and 432 .

343 Rafinesque, C. S. and Clifford, J. D. Prodrome d'une monographie des turbinolies fossiles du Kentuky (dans l'Amériq. septentr.) Par C. S. Rafinesque, Professeur de botanique et d'his- 
toire naturelle à l'Université, et J. D. Clifford, Naturaliste à Lexington en Kentuky. Annales Générales des Sciences Physiques, tome cinquième, pp. 231-235, Bruxelles, 1820.

See number 362.

344 Rafinesque, C. S. Monographie des coquilles bivalves fluviatiles de la rivière Ohio, contenant douze genres et soixantehuit, espèces. Par M. C. S. Rafinesque, Professeur de botanique et d'histoire naturelle à l'Université Transylvane de Lexington. Annales Générales des Sciences Physiques, tome cinquième, pp. 287322, Bruxelles, 1820.

This article is illustrated with three plates. It was also issued as a separate and later translated into English by C. A. Poulson and issued in Philadelphia in 1832. There is a Paris edition, dated 1845.

See numbers 363, 608, and 934.

345 RAFinesque, C. S. Remarques sur les rapports naturels des genres Viscum, Samolus et Viburmum. Annales Générales des Sciences Physiques, tome cinquième, pp. 348-351, Bruxelles, 1820.

346 Rafinesque, C. S. Tableau analytique des ordres naturels, familles naturelles et genres, de la classe endogynie, sous classe corisantherie. Par C. S. Rafinesque, Professeur de botanique à Lexington. Annales Générales des Sciences Physiques, tome sixième, pp. 76-89, Bruxelles, 1820.

Also issued as a separate. See number 364 .

347 Rafinesque, C. S. Remarques sur le genre Eustachya, avec une nouvelle espèce. Annales Générales des Sciences Physiques, tome sixième, pp. 97-98, Bruxelles, 1820.

See number 364.

348 Rafinesque, C. S. Sur les animaux polistomes et porostomes. Par C. S. Rafinesque, professeur de botanique et d'histoire naturelle à l'université de Lcxington en Kentucky. Annales Générales des Sciences Physiques, tome sixième, pp. 359-364, Bruxelles, 1820.

See number 365 .

349 RAFInESQUE, C. S. Remarques sur trois erreurs ichthyologiques. Annales Générales des Sciences Physiques, tome sixième, pp. 369-371, Bruxelles, 1820.

See number 365 . 
350 [RAFinesque, C. S. Remarques sur le genre Jeffersonia.] Annales Générales des Sciences Physiques, tome septieme, p. 18, Bruxelles, 1820.

351 [RAFInesque, C. S. Sur le nouveau genre Enemion.] Annales Générales des Sciences Physiques, tome septieme, pp. 18-19, Bruxelles, 1820.

352 [RAFINESQUe, C. S. Remarques sur les noms de Marathrum et Pythagorea.] Annales Générales des Sciences Physiques, tome septieme, p. 19, Bruxelles, 1820.

353 [RAFINESQUE, C. S. Nouveau caractére de L'Irillium Sessile.] Annales Générales des Sciences Physiques, tome septieme, p. 19, Bruxelles, 1820.

354 RAFInESQue, C. S. Sur quelques animaux hybrides. Par M. C. S. Rafinesque, Professeur de botanique et d'histoire naturelle dans l'Université de Lexington en Kentuky. Annales Générales des Sciences Physiques, tome septieme, pp. 85-88, Bruxelles, 1820.

See number 366 .

355 RAFinesque, C. S. Nomenclature synandrique ou descriptions des différens modes d'union parmi les étamines. Par C. S. Rafinesque, professeur de botanique, etc. à Lexington en Kentuky. Annales Générales des Sciences Physiques, tome septieme, pp. 101-107, Bruxelles, 1820.

See number 366.

356 Rafinesque, C. S. Sur les genres Tridynia, Steironema, Lysimachia, etc. avec la description d'une nouvelle espèce. Par M. Rafinesque, prof. à l'Univ. de Lexington. Annales Générales des Sciences Physiques, tome septieme, pp. 192-193, Bruxelles, 1820.

See number 367.

357 Rafinesque, C. S. Sur le genre Manis et description d'une nouvelle espèce: Manis Ceonyx. Par M. C. S. Rafinesque, professeur de botanique, à Lexington. Annales Générales des Sciences Physiques, tome septieme, pp. 214-215, Bruxelles, 1820.

See number 367.

358 RAFINESQUE, C. S. Extrait de la correspondance de $M$. 


\section{PRODROME}

D'UNE

\section{MONOGRAPHIE DES ROSIERS}

DE L'AMÉRIQUE SEPTENTRIONALE,

Contenant la description de quinze nouvelles espèces et vingt vaarićtés.

Par M. C. S. RAFINESQUE.

\section{S U R \\ LE GENRE HOUSTANIA}

ET DESCRIPTION DE PLUSIEURS ESPÈCES NOUVELLES, ETC.

Par le même.

PRODROME

\section{D'UNE}

\section{MONOGRAPHIE DE TURBINOLIES}

FOSSILES DU KENTUKI (dans l'Amériq. septentr.)

Par MM. C. S. RAFINESQUE et J. D. CLIFForid.

Extraits de la $14^{\text {me }}$ livraison du $5^{\text {me }}$ tome des Annales générales des Sciences physiques.

\section{A BRUXELLES,}

De l'Imprimerie de Weissanbrecu pìre, rue du Musće, nº rõ̃g.

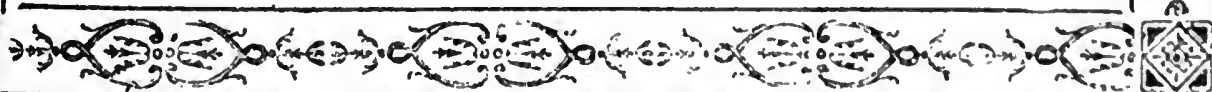

No. 362. Title to Rafinesque's reprint of his monograph on the Roses, etc. 
C. S. Rafinesque. Alluvions fuviatiles. Annales Générales des Sciences Physiques, tome septieme, p. 387, Bruxelles, 1820.

359 [RAFinesque, C. S.] Botanique; genres Chetyson, Enemion et Stylypus. Annales Générales des Sciences Physiques, tome septieme, p. 387, Bruxelles, 1820.

360 [RAFINESQUE, C. S.] Météorologie. [Sur les explosions orageuses.] Annales Générales des Sciences Physiques, tome septieme, pp. 387-388, Bruxelles, 1820.

361 [RAFinesque, C. S.] Géologie. [Sur les Knob-hills du Kentucky et de l'Ohio.] Annales Générales des Sciences Physiques, tome septieme, p. 388, Bruxelles, 1820.

362 Rafinesque, C. S. and Clifford, J. D.: |- - Prodrome | d'une | monographie des rosiers | de l'Amérique septentrionale, | Contenant la description de quinze nouvelles espèces et | vingt variétés. | Par M. C. S. Rafinesque. $|=|$ sur | le genre Houstania | et description de plusieurs espèces | nouvelles, etc. $\mid$ Par le même. $|=|$ prodrome | d'une | monographie de turbinolies | fossiles du Kentuki (dans l'Amériq. septentr.) | Par MM. C. S. Rafinesque et J. D. Clifford. $|-|$ Extraits de la $14^{\text {me }}$ livraison du $5^{\text {me }}$ tome des Annales | générales des Sciences physiques. $|\longrightarrow|$ a Bruxelles, | De l'Imprimerie de Weissenbruch père, rue du Musée, $n^{\circ}$. 1057. $|-|$ [1820] |

Pamphlet, octavo in size, $12 \mathrm{mo}$ in fold, pp. [i-ii], 1-20, [iii-iv]. The cover pages are not numbered. Title on first page of cover. This pamphlet was issued in 1820 .

See Plate XIII.

Copies of this pamphlet are in the Library of the State Historical Society of Wisconsin; Library of Harvard Museum of Comparative Zoölogy; Library of the Gray Herbarium; Library of the Smithsonian Institution; Yale University Library; Library of Congress; and the Library of the New York Botanical Garden.

See numbers 340,341 , and 343.

363 RAFinesque, C. S.: | Monographie | des coquilles | bivalves et fluviatiles | de la rivière Ohio, | Contenant douze Genres et soixante-huit Espèces. $|=|$ remarques $\mid$ sur $\mid$ les rapports naturels des genres | Viscum, Samolus et Viburnum. | Par M. C. S. Rafinesque. $|-|$ Extrait de la $15^{\text {me }}$ livraison du $5^{\text {me }}$ tome des Annales | générales des Sciences physiques. $\left|\_\right|$a Bruxelles, $\mid$ De l'Imprimerie de Weissenbruch père, rue du Musée, no. 1057. | 
Paper octavo in size and fold, pp. [i-ii], 21-60, [iii-iv], plates 3. The title is on the cover.

Copies seen are in the Library of Harvard Museum of Comparative Zoölogy; Yale University Library; and the Library of Harvard University. There is also a copy in the Library of the Historical and Philosophical Society of Ohio.

See numbers 344, 608, and 934.

364 RAFINESQUE, C. S.: | Tableau analytique | des | ordres naturels, familles naturelles | et genres, de la classe endogynie, sous | classe corisantherie. | Par C. S. Rafinesque. $=\mid$ remarques | sur le genre Eustachia, | avec une nouvelle espèce. | Par le même. $|-|$ Extrait de la $16^{\text {me }}$ livraison du $6^{\text {me }}$ tome des Annales | générales des Sciences physiques. | - | a Bruxelles, | De l'Imprimerie de Weissenbruch père, rue du Musée, no. 1057. | [1820] |

Paper, octavo in size and fold, pp. [i-ii], 61-76, [iii-iv].

Copies seen are in the Library of Harvard Museun of Comparative Zoölogy; Library of the Gray Herbarium; and the Library of the Smithsonian Institution.

See numbers 346 and 347.

365 Rafinesque, C. S.: | Sur | les animaux polistomes | et porostomes. | Par M. C. S. Rafinesque. $|=|$ remarques | sur | trois erreurs ichthyologiques. | Par le même. | - Extrait de la $18^{\text {me }}$. livraison du $6^{\text {me }}$ tome des Annales $\mid$ générales des Sciences physiques. $\mid \longrightarrow$ a Bruxelles; | De l'Imprimerie de Weissenbruch père, rue du Musée, no. 1057. | [1820] |

Paper, octavo in size and fold, pp. [i-ii, 77], 78-85, [86-88 blank, iii-iv.] Contents :

Sur les animaux polistomes et porostomes. Par C. S. Rafinesque, professeur de botanique et d'histoire naturelle à l'université de Lexington en Kentucky, pp. [77]-82. See number 348 .

Remarques sur trois erreurs ichthyologiques. Par le Professeur C. S. Rafinesque, pp. 83-85. See number 349.

Copies seen are in the Library of Harvard Museum of Comparative Zoölogy; Library of Congress; and the Library of the Smithsonian Institution.

366 Rafinesque, C. S.: | Sur | quelques animaux hybrides. | Par M. C. S. Rafinesque. $|=|$ nomenclature $\mid$ synandrique, $\mid$ ou | descriptions des différens modes | d'union parmi les étamines. Par le même. | - Extrait de la 19me livraison du $7^{\text {me }}$ tome des Annales | générales des Sciences physiques. | _ | a Brux- 
elles, | De l'Imprimerie de Weissenbruch père, rue du Musée, no. 1057. | [1820] |

Paper, octavo in size and fold, pp. [i-ii], 87-97, [98 blank, iii-iv.] Contents :

Sur quelques animaux hybrides. Par M. C. S. Rafinesque, Professeur de botanique et d'histoire naturelle dans l' Université de Lexington en Kentucky, pp. 87-90. See number 354.

Nomenclature synandrique ou descriptions des différens modes d'union parmi les étamines. Par C. S. Rafinesque, professeur de botanique, etc. à Lexington en Kentuky, pp. 91-97. See number 355 .

Copies seen are in the libraries of the Harvard Museum of Comparative Zoölogy; Library of Congress; Library of the Gray Herbarium; and the Library of the Smithsonian Institution.

367 Rafinesque, [C. S.]: | Sur les genres | Tridynia, Steironema, | Lysimachia, etc. | avec | la description d'une nouvelle espèce. | PAR M. Rafinesque. $|=|$ sur le genre | Manis, | et | description d'une nouvelle espèce: | Manis ceonyx. | Par le même. | - Extrait de la 20me. livraison du $7^{\text {me }}$ tome des Annales $\mid$ générales des Sciences physiques. | $\mid$ a Bruxelles, | De l'Imprimerie de Weissenbruch, Imprimeur du Roi, | rue du Musèe, no. 1057.

Paper, octavo in size, folio in fold, pp. [i-ii], [96], 97-99, [iii-iv].

Copies examined are in the Library of Harvard Museum of Comparative Zoölogy; and the Library of the Smithsonian Institution.

See numbers 356 and 357.

368 RAFinesque, C. S. Description D'un nouveau genre de Plantes, Enemion, et Remarques botaniques; Par M. C. S. Rafinesque, Professeur de Botanique et d'Histoire naturelle dans l'Université de Lexington en Kentucky, et Membre de plusieurs Sociétes savantes, etc. Journal de Physique, de Chemie, d'Histoire Naturelle et des Arts, tome XcI, pp. 70-72, Paris, Juillet au 1820.

369 RafinesQue, C. S. Three notices of natural history. Kentucky Reporter, Lexington, September 6, 1820.

Gives notes on "Kaguar", the skullcap flower, and the production of pearls.

370 RAFinesQue, C. S.: | Annals of nature | or | annual synopsis | of new genera and species of animals, plants, \&c. | discovered in North America: $|=|$ by C. S. Rafinesque, | Professor of Botany and Natural History in Transylvania University, at Lexington / in Kentucky, and member of several Learned So- 
cieties in the $\mid$ United States and in Europe, \&c. $|=|$ exertion unfolds and increases knowledge. $|=|$ First Annual Number, for 1820. $|=|$ dedicated to Dr. W. E. Leach, | of the British Museum, London. $\mid=1$

Pamphlet, octavo in size, quarto in fold, pp. [1], 2-16. The above is the subtitle given on the first page; the text follows. No cover title has been seen by the writer.

Printed by Thomas Smith at Lexington, Kentucky. The announcement is signed: "C. S. Rafinesque, Transylvania University, March 1, 1820."

Copies of this pamphlet are in the Library of the Gray Herbarium; Library of the American Philosophical Society; Library of the Missouri Botanical Garden; Library of Congress; Library of the Academy of Natural Sciences of Philadelphia; Library of the New York Botanical Garden; Library of the Smithsonian Institution; and the Library of the Historical and Philosophical Society of Ohio.

See number 939.

371 Rafinesque, C. S. Sur Plusiers Nouveaux genres de Mollusques. Journal de Physique, de la Chimie et D'Histoire Naturelle, et des Arts, tome LxxxviII, p. 417, Paris, 1820.

372 Rafinesque, Professor [C. S.] Monthly results of meteorological observations; Made in Lexington by Professor Rafinesque. The Western Review and Miscellaneous Magazine, vol. III, no. 6, pp. 375-377, Lexington, January, 1821.

Gives "No. 10. Results for October, 1820. No. 11. Results for November 1820. No. 12. Results for December, 1820," with short phænological notes.

373 RaFinesQue, C. S. Description d'une araignée qui constitue un genre nouveau. Par M. C. S. Rafinesque, professeur à l'université de Lexington. Annales Générales des Sciences Physiques, tome huitieme, pp. 88-89, Bruxelles, 1821.

Describes the spider, Tessarops maritima, defines the genus, and gives a colored plate.

374 Rafinksque, C. S. Remarques sur les Convolvulacées, etc. Par M. Rafinesque, prof. à l'Univ. de Lexington. Annales Générales des Sciences Physiques, tome huitieme, pp. 268-272, Bruxelles, 1821.

375 [RAFinesque, C. S.] : | Western Minerva, | or | American Annals | of $\mid$ Knowledge and Literature, $|-|$ un peu de tout. $|\longrightarrow|$ food for the mind. $|=|$ first volume. $\mid$ for 1821. 
$1=\mid$ Lexington, Kentucky. | Published for the editors, by Thomas Smith, in quarterly num- | bers, four of which form a volume, at $\$ 2$ per annum. $|-| 1821$.

Pamphlet, octavo in size, quarto in fold, pp. [i-v], vi, [7], 8-88. The third line is in reversed Italics. The above is the title on the first page, the inner subtitle on page [7] reads:

Western Minerva, | or | American Annals of Knowledge and Literature. $|=|$ Containing Original Essays upon Science, the Arts, Literature, and subjects connected with the / Civil and Natural History of the Western States. $|=|$ Vol. I. Lexington, (Ky.) January, 1820. No. 1. 1

The third line is in reversed Italics.

Pages [7]-88 are in double columns.

It is said that only three copies were saved by the editor and proprietor, C. S. Rafinesque. It is further stated that the bulk of the edition was destroyed by the irate printer because the money to pay his bill was not immediately forthcoming. See Rafinesque, Life of Travels, p. 66; Call, Life and Writings of Rafinesque, pp. 169-170.

A copy of the Western Minerva may be seen in the library of the Academy of Natural Sciences of Philadelphia.

Collation: Title, p. [i] ; page [ii] blank; dedication "to the Trustees, President, Professors and Tutors of Transylvania University * * *", p. [iii]; page [iv] blank; preface [dated: Lexington, January, 1821], pp. [v]-vi; inner sub-title followed by text, p. 7, text, pp. 7-88.

The following articles are included:

376 [Rafinesque, C. S.] Legislation. Principles of Political Wisdom, or a selection of One hundred political Laws and Precepts, collected from the works of Pythagoras and his Disciples.-translated from the Greek, by Benjamin Franklin, pp. 7-11.

377 [Rafinesque, C. S.] Ethics, or Moral Philosophy. The Moral Decameron, or Principles of Moral Conduct -A selection of Moral Precepts, translated from the Greek of Pythagoras and his Disciples, by Benjamin Franklin, pp. 11-18.

378 [Rafinesque, C. S.] Metaphysics. Theory of the Creation or Emanation of Beings, \&c., pp. 18-22. Signed by Leibnitz and dated Lexington, October, 1820.

379 RAFINESQUe, C. S. Astronomy. Enquiries on the Siderial, or Upper Spheres, pp. 22-26. Dated, Transylvania University, 22d October, 1820.

380 Rafinesque, C. S. Meteorology. Letter on Atmospheric Dust, addressed to Governor De Witt Clinton, Albany, pp. 27-29. Dated: Transylvania University, 1st October, 1820.

381 R. [AFINESQUE], C. S. Physics. On a New Property in Light, 
by Captain Forman. With notes, by C. S. Rafinesque, pp. 29-30. Signed in two places at and near the end: "C. S. R."

382 M. [-] Synopsis of some Discoveries on Heat, made in 1818, pp. $30-31$.

383 M. [-] Mathematics. On Descriptive Geometry, p. 31.

384 ARChIMEDES. [-] On Isomerical Numbers, or Common Multiples, pp. 31-33.

385 M. [-] Chemistry. Synopsis of the Principal Discoveries, \&c. made in Chemistry in 1818 , p. 34 .

386 [RAFINESQUe, C. S.] The Chemical Art of converting pure Woody Substances into Gum and Sugar, \&c. (Abridged by Professor Rafinesque), pp. 35-37.

387 M. [- $[$ Selection of late European Discoveries in Chemistry, p. 37.

388 M. [-] Mineralogy. New Mineral Species discovered or ascertained in 1818 , pp. $37-38$.

389 C. [LINTON], D [e Witt]. Notice on the Hydraulic Limestone, by H. E. De Witt Clinton, Governor of the state of New-York, \&c. in a letter to Professor Rafinesque, p. 38. An appended note by Rafinesque further describes the material.

390 T. [ORREY], J[OHN]. Original Scientific Intelligence, or discoveries and remarks on natural sciences; Extracted from a letter of Dr. John Torrey, Vice-President of the Lyceum of Nat. History of New-York, to Professor Rafinesque, pp. 38-40. Dated: N. York, 28th July, 1820.

391 R. [AFINESQUE], C. S. Botany. Botanical Discoveries made in Kentucky in 1820 , by Prof. Rafinesque, extracted and translated from a letter to Prof. Decandolle of Geneva in Switzerland, author of the New Species Plantarum, \&c., pp. 40-42. Dated: Lexington, 1st December, 1820.

392 Rafinesque, C. S. On the several species of the genus Clintonia, addressed to Dr. Samuel L. Mitchell, in a letter dated 26th September, 1819, pp. 42-43. Dated: Lexington, 10th September, 1819.

393 Agricola. [-] Agriculture. Practical Remarks and Results on the Agriculture of the Western States, or on the Cultivation of Corn, Wheat, Hemp and Tobacco in 1820, pp. 43-46. Dated: "Fayette County, Ky. 16th, November, 1820."

394 Agricol, A. [-] Manufactures. On the various Manufactures from Flour, pp. 47-48.

395 W. M. [-] Statistics. Statistical View of the Town of Lexington in Kentucky, in December 1820, p. 49.

396 [-] View of the Public Institutions for Instruction in Spain and the United States, pp. 50.

397 Mentor. [-] United States of America, p. 51.

398 MeNToR. [-] Remarks on Public Instruction in the State of New York, pp. 51-52.

399 R. [AFINESQUE], C. S. Archæology. Alleghawee Antiquities of 
Fayette County, Ky. in a letter of Professor Rafinesque to the American Antiquarian Society, pp. 53-57. Dated: "Lexington, 3d January, 1821." 400 D. R. [-] Medicine. On some specific remedies for Mortification, Consumption, Hydrophobia, \&c., pp. 57-58.

401 R. [AFINESQUE], C. S. Notices of Materia Medica, or new medical properties of some American Plants, pp. 58-59.

402 W. M. [-] Selection of late American Discoveries, pp. 59-60.

403 Z. [-] Literature and varieties. The Siftcr.-No. 1, pp. 60-62.

404 W. M. [-] The Querist.-No. 1, pp. 62-64.

405 O. I. [-] Female Free-Masonry.-No. 1 Initiation and Catechism of the Female Apprentice, translated from the sacred language, by a Holy Brother of the Highest Degree, O. I., pp. 64-65.

406 W. M. [-] Western Literature. Works published in the Western States in 1820, pp. 66-67.

407 CEDipus. [-] The Sphynx.-No. 1, p. 67.

408 [Rafinesque], Constantine. Polygryphs, p. 67.

409 Hystrix, P. The Monkeys.-No. 1, pp. 68-69.

410 Hystrix, Doctor Porcupine, of Cincinnati. Future Epitaphs, pp. $69-70$.

411 [RAFinesque, C. S.] Fragments of Correspondence, \&c. Fragments from a letter of Mr. Bory St. Vincent, member of the Academy of Sciences of Paris, to Professor Rafinesque, translated from the French, pp. 70-71; dated: "Bruxelles, 10th August, 1820." "Annals of Physical Sciences," p. 71.

412 [RAFInESQUE, C. S.] Zoological Illustrations, by W. Swainson, pp. 71-72.

413 Rafinesque, C. S. Fragments of a Letter to Mr. Bory St. Vincent at Paris (member of the Academy of Sciences of Paris, Author of Travels in the Islands of Africa, \&c.) on various subjects.-Translated from the French, pp. 72-76. Dated: "Lexington, 7th January, 1821."

414 Lavinia [- ] Fragments of Letters from Lexington, by a lady, Western Athens-Society-Parties-Balls-Belles and Beaux, pp. 77-79. Comments on social life in Lexington.

415 W. M. [-] A View of some American Universities and Colleges in 1820 , pp. $79-80$.

416 W. M. [—] Transylvania University, p. 80.

417 R. [AFInesque], C. S. Poetry. The Western Muses, or, Original

Poetry. Les Rives de L'Ohio. Poeme en deux chants, pp. 81-82.

418 R. [AFINESQUe], C. S. Couplet pour Silvie, p. 83.

419 M. T. [-] A Melody, My heart is gone, p. 83.

420 Virginia. [-] A Melody. The Man I'll Love, p. 83.

421 R. [Afinesque], C. S. La Double Aurore. Ode Anacreontique, pp. 83-84.

422 R. [AFINESQUE], C. S. Le Reveil d' Irma. Ode Anacreontique, p. 84. Dated: October, 1819. 
423 R. [afinesque], C. S. L'Enfant et l'Epouse Endormis. Romance, p. 84. Dated: "Oct. 1819."

424 R. [AFInesque], C. S. Preceptes Moraux. 1. Le Secret d'etre heureux. 2. Amour et Jalousie, p. 84.

425 Milion [-] The Blind Lover, p. 85.

426 [RAFINESQUe], Constantine. Lines to Maria. Who asked me if I should like to Love in a Cottage, p. 85.

427 J. B. [-] To Silvia, p. 85-86.

428 B. T. [-]. Trifles, by Billy 'Tickler of Frankfort, p. 86.

429 [Rafinesque], Constantino. Italian Stanzas. Un Consiglio d'Amore, p. 86.

430 Epigrams, p. 87; The Elysian Dream. To my Sister, [signed by Eleonora], p. 87; To the Sun; To the Moon; On the Loss of a Friend, [all three signed by Eleanora], p. 88; One Word and Only One, To Eliza; To Miss M-, who wished to know what she should read, [both signed by Oscar], p. 88 .

See numbers $336,342,431$, and 432.

The only copy examined by the writer is in the library of the Academy of Natural Sciences of Philadelphia.

431 [RAFinesque, C. S.] : | Western Minerva; | or, | American Annals of Knowledge | and Literature; | a quarterly journal to be published in | Lexington Kentucky. $|=|$ un peu de tout. $|=|$ prospectus. I Kentucky Gazette, new series, vol. viI, no. I, p. [1], column [4], Lexington, January 4, 1821. (Old series, vol. $\mathrm{xxxv}$.)

The same, in same place and position, January 11 and 18, 1821. It may have occurred in the issue for January 25,1821 , but is absent from the issue for February, 1, 1821.

See numbers $336,342,475$, and 432 .

432 [RAFinesQue, C. S. Notice of the suspension of The Western Minerva.] The Kentucky Reporter, Lexington, January $28,1821$.

See numbers 336, 342, 375, and 431.

433 Rafinesque, C. S. ART. VIII. Description of a fossil Medusa, forming a new genus. Trianisites Cliffordi, by C. S. Rafinesque. The American Journal of Science and Arts, vol. III, no. 2, pp. 285-287, 1821.

The communication is dated "Philadelphia, 12th January, 1819."

A cut of the species is given.

See number 450 .

434 Rafinesque, C. S. : | Essay on the natural his- | tory of 
the chirper, or | locust, | Which appears every seventeen years in the | United States. | by Prof. C. S. Rafinesque. | First Essay. | Kentucky Gazette, new series, vol. 7, no. 28, p. [2], columns [4-6], Lexington, July 12, 1821. (Old series, vol. xxxv.)

This essay is dated "June, 1821." It gives a popular account of the seventeen year locust, Cicada septemdecim L., then prevalent in Kentucky. References are made to the locusts of other countries.

The only file of the Kentucky Gazette seen by the writer is the imperfect file in the Library of Congress and as a consequence all references to the Kentucky Gazette in this bibliography refer to this file.

435 Rafinesque, C. S.: | Proposals | to publish by subscription | a selection of the $\mid$ miscellaneous works and essays of $\mid \mathrm{C}$. S. Rafinesque, | Professor of Botany and Natural History, \&c. in Transylvania University. | Member of the Lyceum, Historical, Literary and Philosophical Societies | of New-York; American Antiquarian Society; Academy of Natural Sci- / ences of Philadelphia; Royal Institute of Naples; Italian Academy of | Arts and Sciences; Medical Societies of Lexington and Cincinnati, \&c. | Author of Analysis of Nature, the Mirror of Sciences, and several | works on Botany and Natural History, \&c. | in 5 volumes, 12mo. | Consisting of a selected collection of Tracts, Memoirs, Dis- | sertations, Lectures, Reviews, Letters, Travels, Tales, Po- $\mid$ ems, \&c. | On various subjects connected with Philosophy, History, | Archeology, Philology, Geography, Agriculture, Legisla- | tion, Public Economy, Ethics, Natural and Mathematical Sciences, the fine and useful Arts, Belles Lettres, Poetry, | \&c. | Je tache d'instruire et de plaire, | Je vous amuse et vous eclaire. $|\longrightarrow|$ to be published in Lexington, Ky. $\mid$

Prospectus of a proposed publication, printed on one side of four octavo leaves. The Prospectus consists of two short paragraphs, followed by a list of forty articles to be included in the proposed publication, and closing with the conditions of subscription, dated: "Lexington, Ky., October, 1821."

The copy examined by the writer has the leaves pasted end to end and contains the signatures of eight subscribers, presumably the original copy used by Rafinesque in canvassing. The price to subscribers was to be one dollar per volume.

Preserved in the Library of Harvard Museum of Comparative Zoology. The sixth line of the title is in reversed italics.

436 Rafinesque, C. S. The cosmonist - no. I. On a large 
Fossil Trilobite of Kentucky. Kentucky Gazette, new series, vol. I, no. 5, pp. [2-3], columns [6 and 1], Lexington, January 31, 1822. (Old series, vol. xxxvi.)

Among various statements a general description of the species Isoctomesa magna is given.

The Gazette for February 7, 1822, is missing. It probably contains "the cosmonist no. II".

437 Rafinesque, C. S. The cosmonist - no. III. On the Birds of Kentucky and a new Swallow. Kentucky Gazette, new series, vol. I, no. 7, p. [3], columns [4-5], Lexington, February 14, 1822. (Old series, vol. xxxvi.)

Proposes as a new species of swallow, Hirundo albifrons, the Blue Bank-Swallow. Hirundo phenicephala is mentioned as being described in "Annals of Nature, no. 1, spec. 16."

438 RAFInESQUE, C. S. The cosmonist - no. iv. On the wandering Sea-birds of the Western States. Kentucky Gazette, new series, vol. I, no. 8, p. [3], column [5], Lexington, February 21, 1822.

Contains notes on various wandering sea birds found occasionally in Kentucky.

439 Rafinesque, C. S. The cosmonist. - no. v. One two new Salamanders of Kentucky. Kentucky Gazette, new series, vol. I, no. 9, p. [3], columns [5-6], Lexington, February 28, 1822. (Old series, vol. xxxvi.)

The species proposed are Urotropis mucronata and Eurycea lucifuga.

The file in the Library of Congress has the issues for February 21 and 28 interchanged.

The Gazette for March 7,1822, is missing. It probably contains "the cosmonist, no. V'I."

440 Rafinesque, C. S. The cosmonist - no. vil. On the Geological Meteoric Formation. Kentucky Gazette, new series, vol. I, no. 11, p. [2], column [6], Lexington, March 14, 1822. (Old series, vol. xxxvi.)

Contains some speculations on atmospheric dust of meteoric origin.

441 RAFinesque, C. S. The cosmonist. - no. viri. On the Botany of the Western Limestone Region. Kentucky Gazette, new series, vol. I, no. 14, pp. [2-3], columns [6 and 1], Lexington, April 4, 1822. (Old series, vol. xx [xxxvi.])

A popular article. 
442 Rafinesque, C. S. The cosmonist. - no. Ix. On two new genera of vernal plants from Kentucky. Kentucky Gazette, vol. I, no. 15, p. [3], column [2], Lexington, April 11, 1822. (Old series, vol. Xxxvi.)

Proposes the genera ENEMion and Strlitus. A single species is given to each, viz: Enemion biternatum and Stylipus vernus.

443 RaFinesque, C. S. The cosmonist. - no. $\mathrm{x}$. On several new Ants of Kentucky and Ohio. Kentucky Gazette, new series, vol. I, no. 17, p. [3], columns [3-4], Lexington, April 25, 1822. (Old series, vol. xxxvi.)

Describes: 1 Formica lutea, $2 F$. succinea, $3 F$. albescens, $4 F$. cardiogaster, $5 F$. hyemalis, $6 F$. melanocephala, $7 F$. dicropus, 8 F. morsitans, $9 F$. gibbosa, $10 F$. astacena, $11 F$. notata, and $12 F$. crocea.

The copy for May 2, 1822, is missing. It probably contains "the Cosmonist, no. XI."

444 [Rafinesque, C. S.] Science. Kentucky Gazette, new series, vol. I, no. 20, p. [3], column [5], Lexington, May 16, 1822. (Old series, vol. xxxvi.)

Consists of a short preliminary statement followed by a letter of Thiebaut de Berneaud, perpetual secretary of the Linnean Society of Paris, dated "17th December, 1821", addressed to C. S. Rafinesque which announced to him that his name had been inscribed among those of its corresponding members of the Linnean Society.

445 Rafinesque, C. S. The cosmonist - no. Xir. On the turtles of the United States. Kentucky Gazette, new series, vol. I, no. 21, p. [3], columns [4-5], Lexington, May 23, 1822. (Old series, vol. Xxxvi.)

Contains general statements. Lists by name ten new species and says that a monograph of these was published in Europe.

446 RafinesQue, C. S. The cosmonist - no. xiII. On the Lizards of the United States. Kentucky Gazette, vol. I, no. 29, p. [3], column [2], Lexington, July 18, 1822. (Old series, vol. xxxvi.)

General statements, mentions by name ten new species. Describes Tupirnambis niger, one of the list.

447 RaFinesque, C. S. The cosmonist - no. xiv. On the Roses of the United States. Kentucky Gazette, vol. I, no. 32, p. [3], columns [3-4], Lexington, August 8, 1822. 
Contains general matters, a list of species, and a description of Rosa viscida.

The issues of the Gazette for the remainder of the year, save the missing issues of November 7 and 14, have been examined but no further articles in continuation of the series of "the cosmonist" were found. Rafinesque in "Atlantic Journal", p. 208, says: "1822. The Cosmonist, 20 numbers, Lexington. New plants of Kentucky."

448 Rafinesque, Prof. [C. S. Announcement of a course of lectures on medical and systematic botany and natural history in] Transylvania University. Kentucky Gazette, vol. I, no. 42, p. [2], column [5], Lexington, October 17, 1822. (Old series, vol. XXVi.)

The same occurs in the issues of October 24 and 31 , occupying in both cases, p. [3], column [3].

449 Rafinesque, Prof. [C. S. Announcement of a] Lecture on Phrenology. Kentucky Gazette, vol. I, no. 50, p. [3], column [4, at the foot], Lexington, December 12, 1822. (Old series, vol. XXVI.)

This is the only instance noticed by the writer of Rafinesque's interest in this pseudo science. In all probability the lecture was a popular one and may have been an exposition of the absurdity of the pretentions of phrenologists.

450 Rafinesque, C. S. Beschreibung einer fossilen Medusa, die eine neue Sippe bildet: Trianisites. Isis Litterarischer Anzeiger, heft 7, p. 749, Jena, 1823.

This is a translation of the article listed as number 433 .

451 RaFinesque, C. S. Clio No. I. Ancient history of North America. The Cincinnati Literary Gazette, vol. I, no. 8, pp. 59-60, February 21, 1824.

452 Rafinesque, C. S. Neophyton, No. I. On a new tree of Kentucky forming a new genus Cladrastis Fragrans. The Cincinnati Literary Gazette, vol. I, no. 8, p. 60, February 21, 1824.

453 Rafinesque, C. S. Neophyton, No. II. On the Genus Collinsia, and tre'o new species of it. The Cincinnati Literary Gazette, vol. I, no. 11, pp. 84-85, March 13, 1824.

454 Q. [RafinisquE, C. S.] Kentucky Institute. The Cincinnati Literary Gazette, vol. I, no. 11, pp. 86-87, March 13, 1824.

Gives a short sketch of the society, also the titles of the papers that have been read at the meetings. 
455 Q. [RAFINESQUE, C. S.] Botanical Garden of Lexington. The Cincinnati Literary Gazette, vol. I, no. 11, p. 87, March $13,1824$.

Gives the founding of the garden, the officers, the capital stock, and the aims of the incorporators.

456 [RAFInesque, C. S.] Clio No. II. Ancient History of North America. - Monuments of the State of Ohio. The Cincinnati Literary Gazette, vol. I, no. 14, pp. 107-108, April 3, 1824.

457 Rafinesque, C. S. Clio No. II. Ancient History of North America. - Monuments of the State of Ohio. (Concluded.) The Cincinnati Literary Gazette, vol. I, no. 15, pp. 116-117, April 10, 1824.

458 Rafinesquf, C. S. Clio, No. III. Ancient history of North America. - On the Mexican Nations. The Cincinnati Literary Gazette, vol. I, no. 19, pp. 146-147, May 8, 1824.

459 [Rafinesque, C. S.] Clio, No. III. (Concluded.) The Cincinnati Literary Gazette, vol. I, no. 20, p. 155, May 15, 1824.

460 R. [AFINESQUE,] C. S. Review. [of] An easy entrance into the Sacred Language, being a concise Hebrew Grammar without points, compiled for the use and encouragement of learners, and adapted to such as have not the aid of a teacher - By Martin Ruter, D. D. Cincinnati, published for the Methodist Episcopal Church, Morgan and Lodge Printers, 1824; I vol. $12 \mathrm{mo.}$ 96 pages. The Cincinnati Literary Gazette, vol. I, no. 21, pp. 161-162, May 22, 1824.

This review is the leading article of the above mentioned number of the Gazette.

461 Rafinesque, C. S. Clio, No. IV. Ancient History of North America. - Biography of the American Solomon. The Cincinnati Literary Gazette, vol. I, no. 22, p. 170, May 29, 1824.

This brought out a sarcastic inquiry by " $B$ " [David G. Burnett] in the next issue, no. 23 , p. 183, June 5, 1824.

462 Rafinesque, C. S. Clio, No. V. To the editor of the Literary Gazette. On Nazahual, the Nabijos and Comanchees. The Cincinnati Literary Gazette, vol. I, no. 26, p. 202, June 26, 1824.

This is a rejoinder to the inquiry mentioned above.

463 Rafinesque, C. S. Neophyton, No. III. On a new 


\title{
ANCIENT HISTORY,
}

OR

\section{ANPPALS OF RENTUCRT;}

\author{
WITH A SURVEY ÓF.THE ANCIENT YONOMENTS
}

OF N.ORTH AMERICA;

And a Tabular Viezo of the Principal Languages and Primi: tive Nations of the whole Earth.

\section{By C. S. RAFINESQUE, A.M; Ph. D,}

Prof. in Trans. Univ. -Sup't: of the Trans. Bot Garden-Sec'y of the Kent. Institute; and member of the following Societies:

Imp. Nat: Cur. of Bonn

Imp. Econ. Suc. of Vienna,

R. Inst. of Sciences of Naples,

It. Ac. of Arts and Sciences,

Lin. Soc. of Paris,

Amer. Antiq. Soc.

Histor. Soc. of New York, Lit. \& Phil. Soc. of New York,
Lyc. of Nat. Hist. of New York. Ac, of Nat. Sc. of Philadelphis, An'iq Soc. of Tennessee, Med. Soc of Cincinnati, Med. Soc. of Lexington, \&c. 8ce. \&oo.

(Nimquam otiosus.)

\section{FRANKFORT, IN KENTUCKY.}

PRINTED TOR THE AUTHOR.

$$
1824 .
$$

No. 467. Title to Rafinesque's "Ancient History or Annals of Kentucky" 
medical plant, Prenanthes opicrina, and a new kind of Opium Opicrine. (Read before the Kentucky Institute, Feb. 11.) The Cincinnati Literary Gazette, vol. II, no. 2, pp. 10-11, July 10, 1824. 464 Rafinesque, C. S. Neophyton, No. IV. On the new genus Lophactis. The Cincinnati Literary Gazette, vol. II, no. 4, p. 28, July 24, 1824 .

465 Rafinesque, C. S. Somiology, ou les lois de la Nomenclature et de la Classification des Vegetaux et des Animaux. 1824.

This publication has not been seen by the writer.

466 RAFINESQUE, C. S.: | Ancient Annals of Kentucky; | or, | introduction to the history and antiquities of the | state of Kentucky. $|=|$ by C. S. Rafinesque, A. M. - Ph. D. | professor in Transylvania university, member of the Kentucky | institute, and 15 other scientific or literary societies | in the United States and in Europe. $|=|$ (Nunquam otiosus.) $\mid$

In $\mathrm{H}$ [umphrey] Marshall's History of Kentucky, vol. I, pp. [ix-xi], xii, 13-47, Frankfort, 1824.

The first line is in reversed italics.

See numbers 467 and $851 \mathrm{f}$.

467 RAFinesque, C. S.: | Ancient history, | or | annals of Kentucky; | with a survey of the ancient monuments | of North Amer$i c a$, And a Tabular View of the Principal Languages and Primi- | tive Nations of the whole Earth. $|\longrightarrow|$ By C.S. Rafinesque, $A M$, Ph.D, | Prof. in Trans. Univ. - Sup't. of the Trans. Bot. Garden - Sec'y of the $\mid$ Kent. Institute, and member of the following Societies: | Imp. Nat. Cur. of Bonn Lit. \& Phil. Soc. of New York, | Imp. Econ. Soc. of Vienna, Lyc. of Nat. Hist. of New York, | R. Inst. of Sciences of Naples, Ac, of Nat. Sc. of Philadelphia, | It. Ac. of Arts and Sciences, Antiq. Soc. of Tennessee, | Lin. Soc. of Paris, Med. Soc. of Cincinnati, | Amer. Antiq. Soc. Med. Soc. of Lexington, | Histor. Soc. of New York, \&c. \&c. \&c. $\mid$ (Numquam otiosus.) $|=|$ Frankfort, in Kentucky. $\mid$

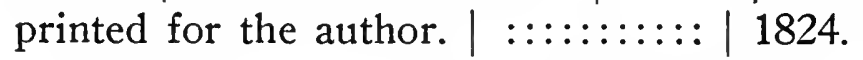

Pamphlet, octavo in size, quarto in fold, pp. [i-iii], iv, [1-3], 4-31, [32-33], 34-37, [38], 39, [40 blank]. The above title is on page [i]. The author says on page [ii]: "These pages are dedicated to Alexander de Humboldt, in token of the high value set upon his researches on America."

The third line is in reversed italics.

See Plate XIV. 
PLATE XV

\title{
INIIRST
}

\section{CATALOGUES AND CIRCULARS}

\author{
OF THE
}

BOTANICAL G.ARDEN OF TRANSYLVANIA

UNIVERSITY AT LEXINGTON IN

KENTUCKY,

$=$

FOR THE YEAR 1824.

PIB]

CAt'alogues hT CIRCULAires

DU JARDIN BOT.ANIQUE DE L'UNIVERSITE'

TRAVSYLVANE A LEXINGTON EN

KENTUCKY

\section{POUR L'ANNEE 1824.}

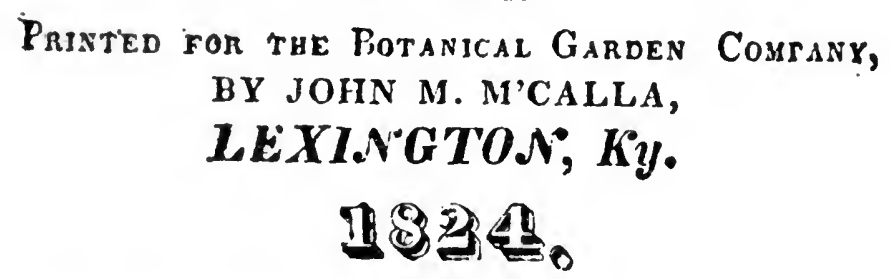

No. 468. Title to Rafinesque's Catalogue of the Botanic Garden 
On page [1] occurs the following title:

Ancient annals of Kentucky; | or, | introduction to the history and antiquities of the $\mid$ state of Kentucky. $|=|$ by C. S. Rafinesque, A. M.-Ph. D. | professor in Transylvania university, member of the Kentucky | institute, and 15 other scientific or literary societies | in the United States and in Europe. $|=|$ (Nunquam otiosus.) $\mid$

This pamphlet received a lengthy review in The Cincinnati Literary Gazette, vol. Ir, no. 26, pp. 202-204, December 25, 1824.

"The antiquarian productions of Rafinesque, which interest us most in this connection, were reviewed with caustic severity by Dr. S. F. Haven, especially the 'Ancient Annals of Kentucky,' which was printed as an introduction to Marshall's History of that State, in 1824. It is, indeed, an absurd production, a reconstruction of alleged history on the flimsiest foundations; but, alas! not a whit more absurd than the laborious card houses of many a subsequent antiquary of renown."-Brinton, The Lenâpé and Their Legends, pp. 150-151.

Copies of Rafinesque's Annals of Kentucky are in the Boston Public Library; The New York Public Library; Library of Harvard University; Library of the Arnold Arboretum; Library of Boston Athenaeum; Library of the State Historical Society of Wisconsin; Library of Congress; Library of the Smithsonian Institution; Chicago Public Library; Library of the University of Pennsylvania; Library of the British. Museum; Library of the Historical Society of Pennsylvania; and the Fitzpatrick Collection.

See numbers 466 and $851 \mathrm{f}$.

468 [RAFINESQUE, C. S.: | First | catalogues and circulars | of the | botanical garden of Transylvania | university at Lexington in | Kentucky, | $\mid$ for the year 1824. | $=\mid$ premiers | catalogues et circulaires |du jardin botanique de l'université | Transylvane a Lexington en $\mid$ Kentucky $|=|$ pour l'annee 1824. I | Printed for the Botanical Garden Company, | by John M. M'Calla, | Lexington, $K y$. | 1824.

Pamphlet, $12 \mathrm{mo}$ in size, $6 \mathrm{mo}$ in fold, pp. [1-3], 4-24. Pages 2-11 inclusive have the English text on the even numbered pages while the French version is on the odd numbered pages. The 7 th and 13 th lines of print of the title are in reversed italics.

See Plate XV.

Contents: title page, p. [1]; circular of the directors of the botanic garden, pp. [2] and 4; French version, pp. [3] and 5; circular of C. S. Rafinesque to his friends and correspondents in America and Europe, pp. 4, 6, 8, and 10; French version, pp. 5, 7, 9, and 11; Florula Kentuckensis. Catalogue of the principal trees, shrubs, and plants of Kentucky, pp. [12]16; II. Catalogue. List of the useful plants, shrubs, and trees either med- 
ical, tinctorial or economical, wanted for the Botanic Garden of Transylvania University, pp. [17]-19; III. Catalogue. Alphabetical list of the ornamental, fragrant or singular plants, shrubs, and trees wanted by the Botanic Garden, pp. [20]-23; remarks, [in two columns, English and French], p. 24.

Copies of this work are in the Library of the State Historical Society of Wisconsin; Library of the Gray Herbarium; and the Library of the New York Botanical Garden.

469 [RAFINesQue, C. S.] : | Prospectus, | by-laws \& charter, | of the Transylvania | botanic-garden company, | - Lexington, 1824. | -

Pamphlet, octavo in size, apparently made up of a $6 \mathrm{mo}$ fold by insertion and a folio, pp. [1], 2-16. The text follows the title. No cover seen.

Contents :

To the public, pp. [1] -4 ; by-laws of the Transylvania Botanic-Garden Company, pp. [5]-12; estimate of the income and expenses of the Transylvania Botanic-Garden Company, pp. [13]-15; charter, pp. 15-16.

Rafinesque's name appears as Secretary at the foot of page 4.

A copy of this pamphlet is in the Library of the Academy of Natural Sciences of Philadelphia.

See number 468.

470 Rafinesque, C. S. Clio, No. VI. On the Panis Language and Dialects. The Cincinnati Literary Gazetter, vol. II, no. 7, pp. 50-51, August 14, 1824.

471 Rafinesque, C. S. Clio, No. VII. On the WhiteTribes of America, \&c. The Cincinnati Literary Gazette, vol. II, no. 23, p. 178, December 4, 1824.

471a. Report of the state of the Library and Museum of Transylvania University, in November 1824, exclusive of the Medical Library. In Report on the Transylvania University, and lunatic asylum, pp. 26-27, [Frankfort, 1824 or 1825].

472 RAFInesque, C. S. Useful Inventions. The Cincinnati Literary Gazetter, vol. III, no. 9, pp. 66-67, February 26, 1825.

There is a sarcastic parody by "Y" in The Cincinnati Literary Ganette, vol. III, no. 12, p. '90, March 19, 1825.

473 RAFINesque, C. S. Clio-No. VIII. On erroneous criticism. The Cincinnati Literary Gazette, vol. III, no. 12, pp. 89-90, March 19, 1825.

This is the leading article and it is a reply to some criticisms of the pamphlet: Ancient History or Annals of Kentucky. 
474 RAFINESQUE, C. S.: | Neogenyton, | or indication of sixtysix new genera of plants | of North America. | $\mid$ by C. S. Rafinesque, | Professor of Botany and Natural History in the University of Lexington, in Kentucky. $|-| 1825 .|=|$ dedicated to Professor Decandolle, of Geneva. $\mid=1$

Pamphlet, octavo in size, folio in fold, pp. [1], 2-4. Text follows the title and consists of sixty-six numbered paragraphs.

Rafinesque advertised this pamphlet for sale at ten cents.

A copy of the original edition is in the Library of the Arnold Arboretum; also in the Library of the New York Botanical Garden. Other libraries having copies are the Library of the Missouri Botanical Garden; the Library of the Field Museum of Natural History; Library of the Gray Herbarium; Library of the U. S. Department of Agriculture; and the Fitzpatrick Collection. A portion of these are probably facsimile copies for such have been distributed.

475 RAFINESQUE, C. S. School of Flora, with figures, Philadelphia.

Given by Prof. Asa Gray as having been published in 1826, also so stated by Rafinesque.

"I only gave 100 wooden cuts in my medical flora, and about 80 in my School of flora; 36 in American Florist, cheap popular work."-Rafinesque, Flora Telluriana, Part. I, p. 24.

Presumably the School of Flora was made up in part at least from the articles published in The Casket, which periodical however first appeared in January, 1827. Otherwise the School of Flora may have been reprinted in The Casket.

Rafinesque in Atlantic Journal, p. 208, says: "1826. School of Flora, with figures, Philadelphia."

475a [Rafinesque, C. S.] [Prospectus of] Outlines of a general history of America. The Saturday Evening Post, vol. v, no. 42, p. [3], column [6], Philadelphia, October 21, 1826.

The same with an additional paragraph occurs in the issue for November 4, 1826, p. [4], column [3] and is editorially alluded to in the same issue, p. [1], column [2].

475b Rafinesque, C. S. [Prospectus of] American history. The Saturday Evening Post, vol. v, no. 47, p. [2], column [1], Philadelphia, November 25, 1826.

.The same occurs in the issue for December 2, 1826, p. [3], column [4]; also December 9, p. [4], columns [2-3]; December 16, p. [4], column [2]; December 23, p. [4], column [2]; and December 30, p. [3], column [5]. 
476 R. [AFInESQUE], C. S. The school of flora. The Casket or Flowers of Literature, Wit \& Sentiment, Philadelphia, January, 1827, no. 1, pp. 32-33.

Describes no. i, Primula auricula; no. ii, Dionea muscipula; no. iii, Tulipa gesneviana; and no. iv, Fragaria vesca. Page 31 contains four cuts illustrating each species. The School of Flora begins with a short introduction.

See numbers 488, 489, 490, and 491.

477 [Rafinesque, C. S.] The school of flora. The Casket or Flowers of Literature, Wit \& Sentiment, Philadelphia, February, 1827 , no. 2 , pp. 74-75.

Describes no. v, Jeffersonia binata; no. vi, Vinca minor; no. vii, Symphytum officinale; and no. viii, Betonica officinalis. Page 73 contains four cuts illustrating the species.

See numbers 493, 494, 496, and 497.

478 [RAFinesque, C. S.] The school of flora. The Casket or Flowers of Literature, Wit \& Sentiment, Philadelphia, March, 1827 , no. 3, pp. 114-115.

Describes no. ix, Franklinia alatamaha; no. $\mathrm{x}$, Oxalis acetosella; no. xi, Styrandra bifolia; no. xii, Berberis vulgaris. Page 113 contains four cuts illustrating the species.

See numbers 498, 500, 502, 504, and 664 .

479 R. [AFINESQUE], C. S. [Remarks on an essay on botany.] The Casket or Flowers of Literature, Wit \& Sentiment, Philadelphia, April, 1827, no. 4, p. 152.

480 [RAFinesque, C. S.] The school of flora. The Casket or Flowers of Literature, Wit \& Sentiment, Philadelphia, April, 1827 , no. 4, pp. 154-155.

Describes no. xiii, Kalmia latifolia; no. xiv, Dictamnus fraxinella; no. xv, Agrimonia eupatoria; no. xvi, Hedera helix. Page 153 contains a cut of each species.

See numbers 506, 507, and 508.

481 R. [AFinesque], C. S. The school of flora. The Casket or Flowers of Literature, Wit \& Sentiment, Philadelphia, May, 1827 , no. 5, pp. 194-195.

Describes no. xvii, Pinckneya bracteata; no. xviii, Leontodon taraxacum; no. xix, Vicia faba; and gives remarks. Page 193 contains a cut of each species.

See numbers 509, 510, and 511 . 
482 [RAFinesque, C. S.] The school of flora. The Casket or Flowers of Literature, Wit \& Sentiment, Philadelphia, June, 1827, no. 6, pp. 233-234.

Describes no. $\mathrm{xx}$, Crategus oxyacantha; no. xxi, Helleborus viridis; no. xxii, Pyrus malus; no. xxiii, Andromeda arborea. Pages 231-232 contain cuts of the species given.

See numbers 514, 515, 516, and 517.

483 [RAFinesque, C. S.] The school of flora. The Casket or Flowers of Literature, Wit \& Sentiment, Philadelphia, July, 1827, no. 7, pp. 269-270.

Describes no. xxiv, Cephalanthus occidentalis; no. xxv, Ilex aquifolium; no. xxvi, Viola tricolor; no. xxvii, Thymus vulgaris. Page 263 contains a cut of each species.

See numbers 518,519 , and 520 .

484 [Rafinesque, C. S.] The school of flora. The Casket or Flowers of Literature, Wit \& Sentiment, Philadelphia, August, 1827, no. 8, pp. 316-318.

Describes no. xxviii, Poterium sanguisorba; no. xxix, Sabbatia centaurium; no. xxx, Erysimum alliaria; and no. xxxi, Solanum dulcamara. Cuts of each species are given on pages 316-317.

See numbers 521, 522, 523, and 524 .

485 [Rafinesque, C. S.] The school of flora. The Casket or Flowers of Literature, Wit \& Sentiment, Philadelphia, September, 1827, no. 9, pp. 356-357.

Describes no. xxxii, Magnolia macrophylla: no. xxxiii, Ruta vulgaris; no. xxxiv, Anemone nemorosa; and no. xxxv, Polypodium vulgare. Page 355 gives cuts of each species.

See numbers 525, 526, 529, and 530 .

486 [RAFinesque, C. S.] The school of flora. The Casket or Flowers of Literature, Wit \& Sentiment, Philadelphia, November, 1827 , no. 11 , pp. 439-440.

Describes no. xxxvi, Erica tetralix; no. xxxvii, Lychnis dioica; no. xxxviii, Ranunculus ficaria; and no. xxxix, Polygonum bistorta. Page 438 contains a cut of each species.

See numbers 532, 533, 535, and 536 .

487 [Rafinesque, C. S.] The school of flora. The Casket or Flowers of Literature, Wit \& Sentiment, Philadelphia, December, 1827 , no. 12 , p. 482. 
Describes no. $\mathrm{xl}$, Juniperus communis; no. xli, Ranunculus acris; and no. xlii, Spartium scoparium. Page 481 contains cuts of each species.

See number 539.

488 R. [AFINESQUE], C. S. The school of flora. The Saturday Evening Post, vol. vi, no. 284, p. [4], column [2], Philadelphia, January 6, 1827.

Gives introduction, and describes and figures, no. i, Dionea muscipula.

See number 476.

489 [RAFinesque, C. S.] The school of flora. The Saturday Evening Post, vol. vi, no. 285, p. [4], columns [3-4], Philadelphia, January 13, 1827.

Describes and figures no. ii, Tulipa gesneviana.

See number 476.

490 [RAFinesque, C. S.] The school of flora. The Saturday Evening Post, vol. vi, no. 286, p. [4], column [1], Philadelphia, January 20, 1827.

Describes and figures no. iii, Primula auricula.

See number 476.

491 [RAFinesQue, C. S.] The school of Flora. The Saturday Evening Post, vol. vi, no. 287, p. [4], column [1], Philadelphia, January 27, 1827.

Describes and figures no. iv, Fragaria vesca.

See number 476.

492 RAFINESQUE, C. S. Important historical and philological discovery. To Peter Duponceau, Esq. The Saturday Evening Post, vol. vi, no. 285, p. [2], columns [2-3], Philadelphia, January $13,1827$.

A general article on ancient alphabets, with references to Otolum or Palenque. The article is dated: "1st. January, 1827."

493 [RAFinesQue, C. S.] The school of flora. The Saturday Evening Post, vol. vi, no. 288, p. [4], columns [1-2], Philadelphia, February 3, 1827.

Describes and figures no. v, Jeffersonia binata.

See number 477.

494 [Rafinesque, C. S.] The School of flora. The Saturday Evening Post, vol. vi, no. 289, p. [4], column [1], Philadelphia, February 10, 1827.

Describes and figures no. vi, Vinca minor.

See number 477 . 
495 [Rafinesque, C. S.] Patent divitial invention. The Saturday Evening Post, vol. vi, no. 290, p. [2], column [4], Philadelphia, February 17, 1827.

Rafinesque here advertises his coupon system which as he rightly says was patented August 23, 1825. The same occurs on p. [4], column [3], February 24, 1827 ; p. [4], column [3], March 3, 1827; p. [4], column [6], March 17, 1827; p. [4], column [3], March 31, 1827; p. [3], column [6], April 21, 1827; p. [4], column [6], April 28, 1827; and p. [3], column [6], June 30, 1827.

See numbers 499 and 505.

496 [Rafinesque, C. S.] The school of flora. The Saturday Evening Post, vol. vi, no. 290, p. [4], column [1], Philadelphia, February 17, 1827.

Describes and figures no. vii, Symphytum officinale.

See number 477.

497 [RAFinesQue, C. S.] The school of flora. The Saturday Evening Post, vol. vi, no. 291, p. [4], column [1], Philadelphia, February 24, 1827.

Describes and figures no. viii, Betonica officinalis.

See number 477.

498 [RAFinesQue, C. S.] The school of flora. The Saturday Evening Post, vol. vi, no. 292, p. [4], column [1], Philadelphia, March 3, 1827.

Describes and figures no. ix, Franklinia alatamaha.

See numbers 478 and 664 .

499 [Rafinesque, C. S.] Divitial invention. The Saturday Evening Post, vol. vi, no. 294, p. [2], columns [1-2], Philadelphia, March 17, 1827.

Here Rafinesque under the name of "Divitius". describes his invention and states the beneficent results which may follow from its application.

See numbers 495 and 505 .

500 [Rafinesque, C. S.] The school of flora. The Saturday Evening Post, vol. vi, no. 294, p. [4], column [1], Philadelphia, March 17, 1827.

Describes and figures no. $\mathrm{x}$, Oxalis acetosella.

See number 478 .

501 R.[AFinesque], C. S. The port of Buffaloe. The Sat- 
urday Evening Post, vol. vi, no. 295, p. [1], column [5], March 24, 1827.

Rafinesque here describes the city of Buffalo, on Lake Erie, as well as giving the hopes and aspirations of its citizens.

502 [Rafinesque, C. S.] The school of flora. The Saturday Evening Post, vol. vi, no. 295, p. [4], column [3], Philadelphia, March 24, 1827.

Describes and figures no. xi, Styrandra bifolia.

See number 478 .

503 [RAFinesque, C. S. Announcement of a lecture on the history and philosophy of the diversity of languages throughout the world.] The Saturday Evening Post, vol. vi, no. 295, p. [3], column [4], Philadelphia, March 24, 1827.

504 [RAFinesque, C. S. The school of flora.] The Saturday Evening Post, vol. vi, no. 296, p. [4], columns [2-3], March $31,1827$.

Describes and figures no. xii, Berberis vulgaris.

See number 478.

505 [RAFinesQUe, C. S.] Remarks on the patent divitial invention. No. II. The Saturday Evening Post, vol. vi, no. 298, p. [2], column [3-4], Philadelphia, April 14, 1827.

This communication is signed "Divitius."

See numbers 495 and 499 .

506 [Rafinesque, C. S.] The school of flora. The Saturday Evening Post, vol. vi, no. 298, p. [4], column [2], Philadelphia, April 14, 1827.

Describes and figures no. xiii, Kalmia latifolia.

See number 480 .

507 [Rafinesque, C. S.] The school of flora. The Saturday Evening Post, vol. vi, no. 299, p. [4], column [2], Philadelphia, April 21, 1827.

Describes and figures no. xiv, Dictamnus fraxinella.

See number 480 .

508 [Rafinesque, C. S.] The school of flora. The Saturday Evening Post, vol. vi, no. 300, p. [4], column [1], Philadelphia, April 28, 1827.

Describes and figures no. xv, Agrimonia eupatoria.

See number 480 . 
509 [Rafinesque, C. S.] The school of flora. The Saturday Evening Post, vol. vi, no. 303, p. [4], column [1], Philadelphia, May 19, 1827.

Describes and figures no. xvii, Pinckneya bracteata.

See number 481 .

510 [RAFinesque, C. S. The school of flora.] The Saturday Evening Post, vol. vi, no. 304, p. [4], columns [2-3], Philadelphia, May 26, 1827.

Describes and figures no. xviii, Leontodon taraxacum.

See number 481.

511 [RAFinesque, C. S.] The school of flora. The Saturday Evening Post, vol. vi, no. 305, p. [4], column [4], Philadelphia, June 2, 1827.

Describes and figures no. xix, Vicia faba.

See number 481.

512 R. [AFINESQUE], C. S. Remarks on sweet shrub and sensitive plants. The Saturday Evening Post, vol. vi, no. 305, p. [4], column [4], Philadelphia, June 2, 1827.

513 [Rafinesque, C. S.] Pulmel. Great medical discovery. The Saturday Evening Post, vol. vi, no. 307, p. [3], column [3], Philadelphia, June 16, 1827.

States that a preventive and remedy for consumption had been announced sometime ago. The remedy is a compound substance called "Pulmel." Speaks of a forthcoming medical dissertation on the different kinds of consumption and of their cure by "Pulmel." The article is signed Medicus.

See numbers 528, 531, 534, 537, 538, 540, 555, and 843.

514 [RaFinesque, C. S.] The school of flora. The Saturday Evening Post, vol. vi, no. 307, p. [4], column [2], Philadelphia, June 16, 1827.

Describes and figures no. xx, Helleborus viridis.

See number 482.

515 [RAFInesque, C. S.] The school of flora. The Satururday Evening Post, vol. vi, no. 308, p. [4], columns [1-2], Philadelphia, June 23, 1827.

Describes and figures no. xxi, Crategus oxyacantha.

See number 482.

516 [RAFInesque, C. S.] The school of flora. The Satur- 
day Evening Post, vol. vi, no. 309, p. [4], column [1], Philadelphia, June 30, 1827.

Describes and figures no. xxii, Pyrus malus.

See number 482.

517 [RAFinesque, C. S.] The school of flora. The Saturday Evening Post, vol. vi, no. 310, p. [4], column [1], Philadelphia, July 7, 1827.

Describes and figures no. xxiii, Andromeda arborea.

See number 482.

518 [RAFinesque, C. S.] The school of flora. The Saturday Evening Post, vol. vi, no: 311, p. [4], column [1], Philadelphia, July 14, 1827.

Describes and figures no. xxiv, Ilex aquifolium.

See number 483.

519 [RAFInESQUE, C. S.] The school of flora. The Saturday Evening Post, vol. vi, no. 314, p. [4], column [2], Philadelphia, August 4, 1827.

Describes and figures no. xxvi, Viola tricolor.

See number 483.

520 [RAFINESQUE, C. S.] The school of flora. The Saturday Evening Post, vol. vi, no. 316, p. [4], column [2], Philadelphia, August 18, 1827.

Describes and figures xxvii, Thymus vulgaris.

See number 483.

521 [RAFInesQue, C. S.] The school of flora. The Saturday Evening Post, vol. vi, no. 317, p. [4], column [2], Philadelphia, August 25, 1827.

Describes and figures xxviii, Poterium sanguisorba.

See number 484.

522 [RaFinesque, C. S.] The school of flora. The Saturday Evening Post, vol. vi, no. 318, p. [4], column [2], Philadelphia, September 1, 1827.

Describes and figures no. xxix, Sabbatia centaurium.

See number 484.

523 [RAFinesgue, C. S.] The school of flora. The Saturday Evening Post, vol. vi, no. 319, p. [4], column [2], Philadelphia, September 8, 1827. 
Describes and figures no. xxx, Erysimum alliaria.

See number 484.

524 [RAFINESQUE, C. S.] The school of flora. The Saturday Evening Post, vol. vi, no. 320, p. [4], column [3], Philadelphia, September 15, 1827.

Describes and figures no. xxxi, Solanum dulcamara.

See number 484.

525 [RAFInEsque, C. S.] The school of flora. The Saturday Evening Post, vol. vi, no. 321, p. [4], column [2], Philadelphia, September 22, 1827.

Describes and figures no. xxxii, Magnolia macrophylla.

See number 485 .

526 [RAFInESQUE, C. S.] The school of flora. The Saturday Evening Post, vol. vi, no. 322, p. [4], column [2], Philadelphia, September 29, 1827.

Describes and figures no. xxxiii, Ruta vulgaris.

See number 485 .

527 [RAFInesQue, C. S. Advertising editorial on Pulmel.] The Saturday Evening Post, vol. vi, no. 323, p. [3], column [3], Philadelphia, October 6, 1827.

528 [Rafinesque, C. S.] Pulmel. A Specific Remedy to Cure and Prevent the Consumption. The Saturday Evening Post, vol. vi, no. 323, p. [3], column [5], Philadelphia, October 6, 1827.

The same article occurs in the following issues: p. [3], column [6], October 20,1827; p. [4], column [3], November 3, 1827; p. [4], column [3], November 10, 1827; p. [4], column [5], November 17, 1827; p. [3], column [6], November 24, 1827; p. [4], column [2], December 1, 1827; and p. [4], column [2], December 8, 1827.

See numbers 513, 531, 534, 537, 538, 540, 555, 573, 574, 575, 576, and 843.

529 [RAFinesque, C. S.] The school of flora. The Saturday Evening Post, vol. vi, no. 323, p. [4], column [2], Philadelphia, October 6, 1827.

Describes and figures no. xxxiv, Anemone nemorosa.

See number 485.

530 [Rafinesque, C. S.] The school of flora. The Saturday Evening Post, vol. vi, no. 324, p. [4], column [1], Philadelphia, October 13, 1827.

Describes and figures no. xxxv, Polypodium vulgare.

See number 485. 
531 [Rafinesque, C. S.] Medical notice, On Indigestion, Bloody Flux, and Consumption. The Saturday Evening Post, vol. vI, no. 325, p. [3], columns [2-3], Philadelphia, October 20, 1827.

Article signed: "Medicus."

See numbers $513,528,534,537,538,540,555$, and 843.

532 [RAFinesque, C. S.] The school of flora. The Saturday Evening Post, vol. vi, no. 325, p. [4], column [2], Philadelphia, October 20, 1827.

Describes and figures no. xxxvi, Erica tetralix.

See number 486.

533 [RAFinesque, C. S.] The school of flora. The Saturday Evening Post, vol. vi, no. 327, p. [4], column [2], Philadelphia, November 3, 1827.

Describes and figures no. xxxvii, Lychnis dioica.

See number 486.

534 [RAFinesque, C. S.] On the pulmel. The Saturday Evening Post, vol. vi, no. 329, p. [3], column [1], Philadelphia, November 17, 1827.

An editorial on the virtues of pulmel as a remedy for consumption signed by "Medicus."

See numbers 513, 528, 531, 537, 538, 540, 555, and 843.

535 [RAFinesque, C. S.] The school of flora. The Saturday Evening Post, vol. vi, no. 329, p. [4], column [2], Philadelphia, November 17, 1827.

Describes and figures no. xxxviii, Ranunculus ficaria. See number 486.

536 [RAFinesque, C. S.] The school of flora. The Saturday Evening Post, vol. vi, no. 330, p. [4], column [2], Philadelphia, November 24, 1827.

Describes and figures no. xxxix, Polygonum bistorta.

See number 486.

537 [RAFinesque, C. S.] Cheering news, For those who have the Consumption. The Saturday Evening Post, vol. vi, no. 330, p. [2], column [2], Philadelphia, November 24, 1827.

An editorial signed by "Medicus." An advertisement for "Pulmel."

See numbers 513, 528, 531, 534, 537, 540, 555, and 843 .

538 [RAFINeSQUE, C. S.] Communication on the pulmel. The Saturday Evening Post, vol. vi, no. 335, p. [2], column [1], Philadelphia, December 29, 1827. 
States that six hundred pounds have been manufactured and sold, that the active principle is pumelin, and that the product is sent out in four different forms.

See numbers 513, 528,531,534, 537, 540, 555, and 843.

539 [RAFINESQUE, C. S.] The school of flora. The Saturday Evening Post, vol. vi, no. 335, p. [4], column [2], Philadelphia, December 29, 1827.

Describes and figures XLI, Ranunculus acris.

See number 487.

540 [RAFinesque, C. S.] Pulmel A Specific Remedy to Cure and Prevent the Consumption. The Saturday Evening Post, vol. vi, no. 335, p. [4], column [4], Philadelphia, December 29, 1827.

Differently arranged from the previous article with the same title and illustrated with a cut.

See numbers $513,528,531,534,537,538,555$, and 843 .

541 [RAFINESQUE, C. S.] The school of flora, new series. The Casket or Flowers of Literature, Wit and Sentiment, Philadelphia, January, 1828, no. 1, p. 43.

Describes no. i, Sigillaria multiflora; and no. ii, Tussilago nivea. Page 42 contains a cut of each species.

542 [RAFINESQUE, C. S.] The school of flora, new series. The Casket or Flowers of Literature, Wit and Sentiment, Philadelphia, February, 1828, no. 2, p. 91.

Describes no. iii, Apocynum androsemifolium and no. iv, Clinopodium vulgare. Page 90 contains a cut of each species.

543 [RAFINESQUE, C. S.] The school of flora, new series. The Casket or Flowers of Literature, Wit and Sentiment, Philadelphia, March, 1828, no. 3, p. 139.

Describes no. v, Ornithopus compressus; and no. vi, Eryngium maritimum. Page 138 contains cuts of the species.

544 [RAFinesQue, C. S.] The school of flora. The Casket or Flowers of Literature, Wit and Sentiment, Philadelphia, April, 1828, no. 4, p. 185.

Describes no. vii, Rosa muscosa; and no. viii, Arum dracunculus. Page 184 contains a cut of each species.

545 [RAFINESQUE, C. S.]. The school of flora, new series. The Casket or Flowers of Literature, Wit and Sentiment, Philadelphia, May, 1828 , no. 5, p. 237. 
Describes no. ix, Hepatica triloba; and no. $\mathrm{x}$, Hibiscus speciosus. Page 236 gives cuts of the species.

546 [RAFinesque, C. S.] School of flora, new series. The Casket or Flowers of Literature, Wit and Sentiment, Philadelphia, June, 1828, no. 6, p. 272.

Describes no. xi, Ipomea quamoclit; and no. xii, Scutellaria lateriflora, giving cuts of each.

547 [RAFinesque, C. S.] School of flora, new series. The Casket or Flowers of Literature, Wit and Sentiment, Philadelphia, July, 1828 , no. 7 , p. 332 .

Describes no. xiii, Aquilegia canadensis; and no. xiv, Alchemilla alpina, giving cuts of each.

548 [RAFinesque, C. S.] School of flora, new series. The Casket or Flowers of Literature, Wit and Sentiment, Philadelphia, August, 1828, no. 8, p. 379-380.

Describes no. xv, Nuttalla grandiflora; and no. xvi, Bryonia alba, giving cuts of each.

549 [RAFINESQUe, C. S.] School of flora, new series. The Casket or Flowers of Literature, Wit and Sentiment, Philadelphia, September, 1828, p. 428.

Describes no. xvii, Chelone glabra; and no. xviii, Fraxinus quadrangularis, giving cuts of each species.

550 [RAFinesque, C. S.] School of flora, new series. The Casket or Flowers of Literature, Wit and Sentiment, Philadelphia, October, 1828, no. 10, p. 475.

Describes no. xix, Cotyledon umbilicus; and no. xx, Gentiana saponaria, giving cuts of each.

551 [RAFinesque, C. S. School of flora, new series.] The Casket or Flowers of Literature, Wit and Sentiment, Philadelphia, November, 1828 , no. 11 , p. 523.

Describes no. xxi, Cactus grandiflorus; and no. xxii, Primula veris, giving cuts of each.

552 [Rafinesque, C. S.] School of flora, new series. The Casket or Flowers of Literature, Wit and Sentiment, Philadelphia, December, 1828 , no. 12 , p. 568.

Describes no. xxiii, Oxycoccus marocarpon; and no. xxiv, Paris quadrifolia, giving cuts of each. 
553 RAFineSQUE, C. S. Neophyton Botanikon, or New Plants of North America.

Mentioned by Prof. Asa Gray as having been published in 1828. Rafinesque in Atlantic Journal, p. 208 says: "1828. * * * Neophyton Botanikon or N. plants of N. America."

554 RAFINESQUE, C. S. : | Medical flora; | or, | manual | of the | medical botany | of the | United States | of | North America. | containing | a selection of above 100 figures and descriptions of medi- | cal plants, with their names, qualities, properties, | history, $\& c .:$ and notes or remarks on nearly | 500 equivalent substitutes. in two volumes. $|=|$ volume the first, $|\mathrm{A}=\mathrm{H}|$ with 52 plates. $|-|$ Medical Plants are compound Medicines prepared by the hands of | Nature, \&c. - Med. Princ. 31. | $\mid$ by C. S. Rafinesque, A. M... Ph. D. | Ex-Prof. of Botany, Natural History, \&c. in Transylv. University of Lex- $\mid$ ington, the Franklin Institute of Philadelphia, \&c. | Member of the Medical Societies of Cincinnati and Lexington - the | Philos. Soc. and Lyceum of New York - the Acad. of Nat. Sc. of | Philadelphia - the Amer. Antiq. Society - the Kentucky Institute - the | Linnean Soc. of Paris the Imp. Nat. Cur. Soc. of Bonn. - the Imp. | Economical Soc. of Vienna - the R. Italian Inst. - the R. Inst. of $\mid$ Nat. Sc. of $\mathrm{Na-}$ ples, $\mathcal{F} c . \mathcal{E} c .|=|$ Philadelphia: | printed and published by Atkinson \& Alexander, | No. 112 Chesnut Street. |-| 1828.

Boards or leather, $12 \mathrm{mo}$ in size, $6 \mathrm{mo}$ in fold, pp. [ia-iva, i], ii-xii, [1], 2-268, plates 1-52. The title on the board covers reads:

Medical flora | of the | United States, | by | Prof. Rafinesque. | $=\mid$ volume $1, \mid$ with 52 plates. $|=|$ Philadelphia. $\mid$ 1828. $\mid$

The book is dedicated to Doctors Torrey and Short, as well as to Stephen Elliott, Esq.

The collation is: p. [ia], title page; p. [iia], copyright notice; p. [iiia], dedication; p. [iva], blank; pp. [i]-xii, introduction; pp. [1]-24, general principles of medical botany; pp. 25-259, body of the work; p. [260] blank, pp. 261-268, additions, corrections, and table of articles.

See numbers 557, 925, and 933.

See Plate XVI.

555 Rafinesque, C. S.: | Price, one dollar. $|=|$ the pulmist; | or, | introduction to the art of curing and preventing the | consumption | or | chronic phthisis. | a medical essay, including a new and better distinc- $\mid$ tion of its causes, kinds, remedies, diets, $\mid$ and other peculiarities. $|-|$ The Consumption is not an 


\section{MEDICAL FLORA;}

OR, IMANUAI

OP TRE

\section{MEDICAL BOTANY}

OP TRB

\section{UTTHMD SHATISS}

OP

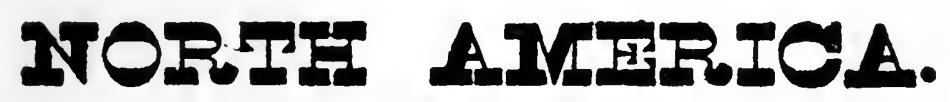

costratarig

$\triangle$ IRLECTION OF $A B O V E 100$ FHOURES $\triangle N D$ DESCRIPTIONS OF YBDL

cal plants, with their makes, QUalities, propertikg,

EIETORT, \&C.: $\triangle N D$ NOTES OR REMARES ON MEARLY

500 EQUITALENT BUESTITUTES.

IN TWO VOLUMES.

VOLUME THE FIRST,

$\therefore=12$

\section{WITH 52 PLATES.}

Medical Plante are compound Medicines prepared by the hands of Nature, \&c.-Med.Priec: 31:-"

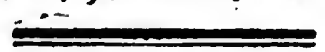

BT C. 8. RAFINESQUE, A. M...PH. D.

Ex.Prof. of Botany, Nateral Historg, \&c. in Transylv. Univeraity of Lexindoo, the Frantlin Institute of Philadelphia, \&c.

Member of the Medieal Societies of Cincinnati and Lexing ton-the Philos. Soc. and Lycewn of New York-the Acad. of Nat. Sc. of Pinlodidpliv-the Amer. Antig. Sociely-the Kentuchy Institute-the Iinivan Soc. of Pario-the Imp. Nat. Cur. Soc. of Bonn.-the Imp. Exonomical Soc. of Vienna-the $\boldsymbol{R}$. Italian Inst.-the $\boldsymbol{R}$. Inst. of Nas. Sc. of Naples, \&.c. \&re.

\section{PHILADELPHIA :}

IRZTTXD AXD PUBLISHED BT ATEINSON \& ALETANDER,

No. 112 Chesnut Street.

1828.

No. 554. Title to the first volume of Rafinesque's "Medical Flora" 
incurable disease; but its reme- $\mid$ dies are to be chiefly conveyed to the lungs by breathing $\mid$ or inhalation-110. $|-|$ by Prof. Rafinesque, Ph. D. \& pulmist. | Professor of Practical and Medical Botany, Natural and Civil | History, \&c. \&c. | Author of the Manual of Medical Botany of the United States, the | Analysis of Nature, and 50 other works or pamphlets. Member of the Medical Societies of Cincinnati and Lexington; the Philadelphia | Society and Lyceum of New York; the Academy of Natural Sciences of Philadel- | phia; the American Antiquity Society of Worcester and Nashville; the Kentucky | Institute, \&c.; and of several learned Societies of Europe, in Paris, Bruxelles, Vi- | enna, Bonn, Florence, Naples, \&c. | _ | Philadelphia: | printed for the author, | By C. Alexander, 112 Chesnut street. $|-| 1829$.

Pamphlet, $12 \mathrm{mo}$ in size, $6 \mathrm{mo}$ in fold, pp. [1-4], 5-72, with one plate. The cover title reads :

The $\mid$ pulmist, $\mid$ or $\mid$ the art to cure $\mid$ and $\mid$ to prevent the $\mid$ consumption. $|-|$ with a figure. $|-|$ by Prof. C. S. Rafinesque. $\mid-1$ Philadelphia: $|-|$ 1829. $\mid$

See Plate XVII.

The inner subtitle reads:

The pulmist: | or, the | art to cure | the | consumption. |

A French translation appeared in 1833.

See number 843.

Copies of The Pulmist are in the Library of the State Historical Society of Wisconsin; Library of the Arnold Arboretum; Library of the Office of the Surgeon-General; Library of the British Museum; Library of the Historical Society of Pennsylvania; and the Fitzpatrick Collection.

556 Rafinesque, C. S. Extrait d'une Lettre de M. C. S. RAFINESQUE, professeur à Philadelphie, addressée à $M$. le professeur De Candolle (Mai 1830.) Bulletin botanique ou collection de notices originales et d'extraits des ouvrages botaniques, par N. C. Seringe, pp. 214-221, Genève, MDCCCXXX.

557 RAFINESQUE, C. S.: | Medical flora; | or | manual | of the | medical botany | of the | United States | of | North America. | containing | a selection of above 100 figures and descriptions of medi- | cal plants, with their names, qualities, properties, | history, $\& c$. : and notes or remarks on nearly $\mid 500$ equivalent substitutes. in two volumes. $|=|$ volume the second, | with 48 plates. | - Medical Plants are compound Medicines, prepared by the hands of $\mid$ Nature, \&c.-Med. Princ. 31. $|=|$ by C. S. Rafi- 


\title{
THE
}

\section{PUIMIS T,}

\author{
OR
}

\section{$\begin{array}{lllll}\text { THE A R T T } & \text { T C URT }\end{array}$}

AND

I0 PREV

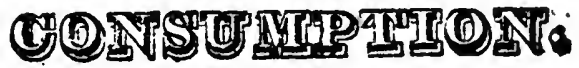

WITH A FTGURE.

BY PROF. C. S. RAFINESQUE.

\section{PHILADELPHIA:}

1820.

No. 555. The cover title to Rafinesque's pamphlet on Consumption 
nesque, A. M.-Ph. D. | Ex-Prof. of Botany, Natural History, \&c. in Transylv. University of Lex- | ington, the Franklin Institute of Philadelphia, \&c. | Member of the Medical Societies of Cincinnati and Lexington-the | Philos. Soc. and Lyceum of New York-the Acad. of Nat.Sc. of | Philadelphia-the Amer. Antiq. Society-the Kentucky Institute-the | Linnean Soc. of Paristhe Imp. Nat. Cur. Soc. of Bonn.-the Imp. Eco- | nomical Soc. of Vienna-the R. Italian Inst.-the R. Inst. of Nat. Sc. of I Naples, \&c. \& c. $|=|$ Philadelphia: | published by Samuel C. Atkinson, | No. 112, Chesnut Street. $|-| 1830 . \mid$

Boards, octavo in size, $6 \mathrm{mo}$ in fold, pp. [1-3], 4-276, plates 53-100.

The title on the board covers reads:

Medical flora | and | botany | of the | United States, | with | one hundred plates, | by | Prof. Rafinesque. $|=|$ second volume, $\mid$ with 48 plates. $|=|$ Philadelphia. | published by S. C. Atkinson, No. 112 Chesnut-street. | .......... | 1830. |

Some copies put out by the publisher have the text of the two volumes bound in one and the plates in another, both in sheep. The author in his Life of Travels, p. 102, speaks of preparing a third volume or supplement which however appears not to have been published. The proposed additional volume is also mentioned on p. 276 , in a footnote at the close of the second volume of the Medical Flora.

The collation is: p. [1], title page; p. [2] copyright notice; pp. [3]-6, introduction; pp. [7]-276, body of the work.

See numbers 554, 925, and 933.

Copies of the Medical Flora are in Yale University Library; Library of the Field Museum of Natural History; Boston Public Library; Library of the American Philosophical Society; Library of the Arnold Arboretum; Library of the State Historical Society of Wisconsin; Library of the New York Botanical Garden; Library of Congress; Library of the Smithsonian Institution; Library of the University of Pennsylvania; The John Crerar Library; The Newberry Library; Library of the Office of the Surgeon-General; Library of the British Museum; Library of the Gray Herbarium; Library of the U. S. Department of Agriculture; Library of the State Historical Society of Pennsylvania; and the Fitzpatrick Collection.

558 RAFINESQUE, C. S.: | Eight figures, | twenty-five cents. | - | American manual | of the | grape vines | and the | art of making wine: | including | An Account of 62 Species of Vines, with nearly $300 \mid$ varieties. An account of the principal Wines, Ame- | rican and Foreign. Properties and uses of Wines $\mid$ and Grapes. Cultivation of Vines in America; and | the Art to make 


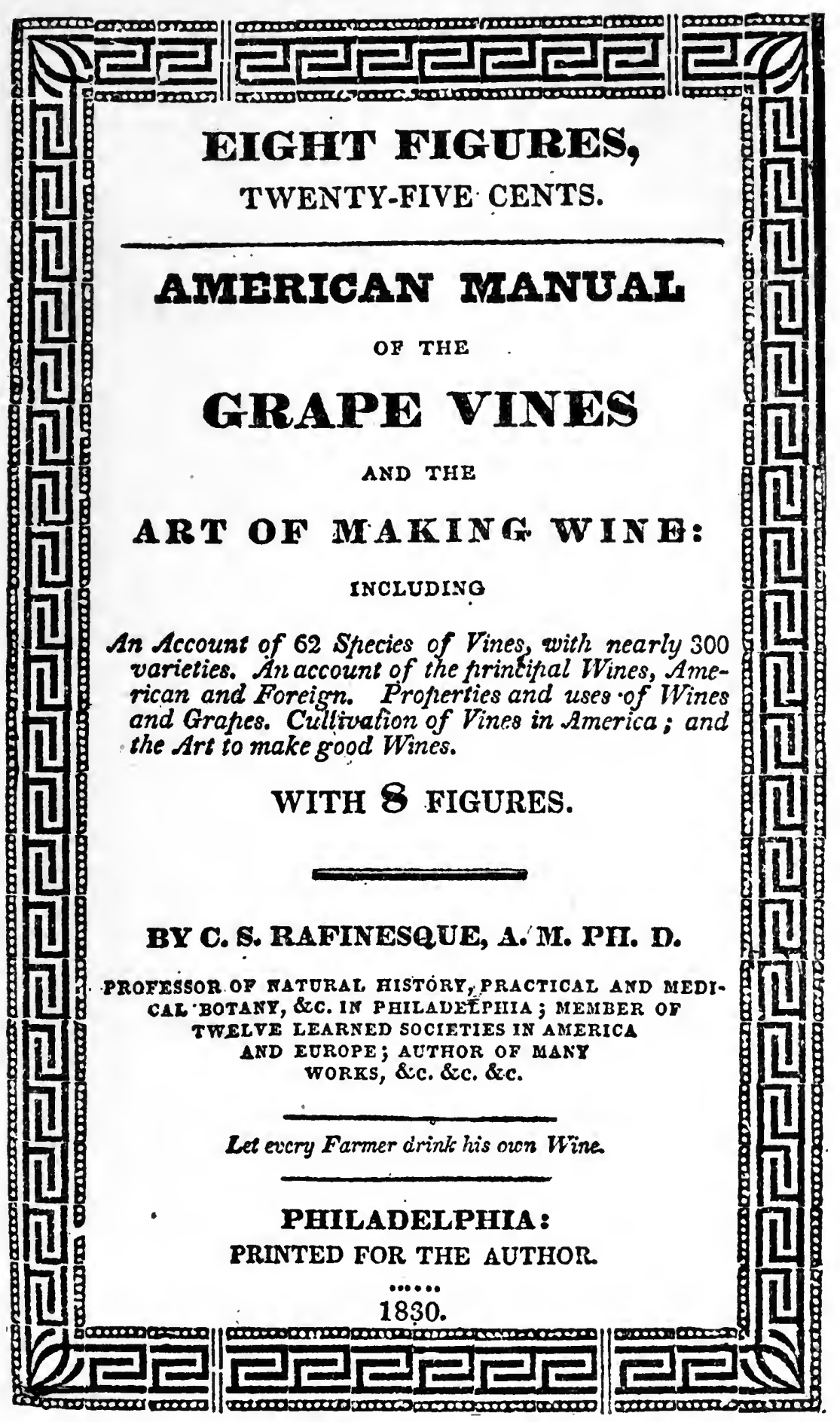

No. 558. Title to Rafinesque's "Manual of the Grape Vines" 
good Wines. $\mid$ with 8 figures. $|=|$ by C. S. Rafinesque, A. M. Ph. D. | professor of natural history, practical and medi- | cal botany, \&c. in Philadelphia; member of $\mid$ twelve learned societies in America | and Europe; author of many | works, \&c. \&c. \&c. | - Let every Farmer drink his own Wine. $\left|\_\right|$Philadelphia: | printed for the author. | ...... | 1830.

Pamphlet, 12mo in size, 6mo in fold, pp. [i-vi, 5], 6-64, [65-66], plates 2, each with 4 figures of grape leaves. Pages [ii, iii, vi, and 65] are blank. Page [66] contains additions to the manual. In some copies pages [65-66] are inserted facing page [5].

See Plate XVIII.

This volume is a reprint of the article on Vitis which occurs on pages 121 to 180 of volume 2 of the Medical Flora, 1830. The running heads and page numbers have been changed, but the body text seems to correspond page for page; pages [5] and 64 of the Manual being equivalent to pages 121 and 180 of the Medical Flora. The two plates are unnumbered and are the equivalents of plates 99 and 100 of the Medical Flora, the legends however having been reset, and the plates are placed after the title page. The additions are a title page, a page of "Additions to this Manual," and the first seven lines on page [5].

Copies of this work are in the Library of the Gray Herbarium; Library of the State Historical Society of Wisconsin; Library of Arnold Arboretum; Yale University Library; Library of the Missouri Botanical Garden; The New York Public Library; Library of the New York Botanical Garden; Library of the Smithsonian Institution; Library of Congress; Library of the U. S. Department of Agriculture; Library of the Historical Society of Pennsylvania; Library of the British Museum; and the Fitzpatrick Collection.

559 [RAFinesque, C. S.] School of flora-new series. The Casket [or] Flowers of Literature, Wit and Sentiment, Philadelphia, February, 1830, no. 2, pp. 86-87.

Describes Eupatorium perfoliatum, giving eut.

560 [RAFinesque, C. S.] School of flora, From the Medical Flora of the United States. The Casket [or] Flowers of Literature, Wit and Sentiment, Philadelphia, March, 1830, no. 3, p. 138.

Describes Cypripedium luteum, giving cut.

561 [RAFinesque, C. S.] School of flora From the Medical Flora of the United States. The Casket [or] Flowers of Literature, Wit and Sentiment, Philadelphia, April, 1830, no. 4, pp. 188189.

Describes Asclepias tuberosa, giving cut. 
562 [RAFinesque, C. S.] School of flora, From the Medical Flora of the United States. The Casket [or] Flowers of Literature, Wit and Sentiment, Philadelphia, May, 1830, no. 5, pp. 232233.

Describes Convolvulus panduratus, giving cut.

563 [Rafinesque, C. S. School of flora.] The Casket [or] Flowers of Literature, Wit and Sentiment, Philadelphia, June, 1830, no. 6, pp. 284-285.

Describes Hyosciamus niger, giving cut.

'564 Rafinesque, C. S. School of flora. From the Medical Flora of the United States. The Casket [or] Flowers of Literature, Wit and Sentiment, Philadelphia, July, 1830, no. 7, pp. 328329.

Describes Cunila mariana, giving cut.

565 RaFinesQue, C. S. School of flora. From the Medical Flora of the United States. The Casket [or] Flowers of Literature, Wit and Sentiment, Philadelphia, August, 1830, no. 8, p. 376.

Describes Gillenia stipulacea, giving figure.

566 Rafinesque, C. S. School of flora. From the Medical Flora of the United States. The Casket [or] Flowers of Literature, Wit and Sentiment, Philadelphia, September, 1830, no. 9, pp. $425-426$.

Describes Cunila mariana, giving cut.

567 Rafinesque, C. S. School of flora. From the Medical Flora of the United States. The Casket [or] Flowers of Literature, Wit and Sentiment, Philadelphia, October, 1830, no. 10, p. 474.

Describes Gentiana catesbei, giving cut.

568 Rafinesque, C. S. School of flora. From the Medical Flora of the United States. The Casket [or] Flowers of Literature, Wit and Sentiment, Philadelphia, November, 1830, no. 11, pp. 521-522.

Describes Cassia Marylindica, giving cut.

569 Rafinesque, C. S. School of flora. From the Medical Flora of the United Statcs. The Casket [or] Flowers of Literature, Wit and Sentiment, Philadelphia, December, 1830, no. 12, p. 568. 
Describes Aristolochia serpentaria, giving cut.

See number 572 .

570 RaFinesque, [C. S.] : | Enumeration and account | of some remarkable natural objects of the cabinet of | Prof. Rafinesque, in Philadelphia ; Being Animals, Shells, Plants, and Fossils, collected by him in North | America, between 1816 and 1831. | $=\mid$ Philadelphia, November, 1831. $|=|$

Pamphlet, octavo in size, quarto in fold, pp. [1], 2-8. Text follows the title and is in two columns to the page.

A copy of this pamphlet is in the Library of the New York Botanical Garden; also Library of Harvard Museum of Comparative Zoölogy; and the Boston Public Library (bound in back of Rafinesque's Continuation of a Monograph of Bivalve Shells).

571 RAFINESQUE, C. S.: | Continuation | of a monograph of the bivalve shells of the river Ohio, $\mid$ and other rivers of the western states. | By Prof. C. S. Rafinesque. | (Published at Brussels, September I820.) | Containing 46 Species, from No. 76, to No. 121. | including an appendix on some / bivalve shells of the rivers of Hindostan, | with a supplement on the | fossil bivalve shells of the western states, | and the Tulosites, | A new Genus of Fossils. | $=\mid$ Philadelphia, October, 1831. $\mid=1$

Pamphlet, octavo in size, quarto in fold, pp. [1], 2-8. Text follows the title and is in two columns to the page.

A copy of this pamphlet is in the Library of the New York Botanical Garden; also Library of Harvard Museum of Comparative Zoölogy; Boston Public Library; and the Library of the Historical and Philosophical Society of Ohio.

572 RAFInesque, C. S. School of flora. From the Medical Flora of the United States. Atkinson's Saturday Evening Post, vol. $x$, whole number 492, p. [1], column [5], Philadelphia, January 1,1831 .

Describes and figures Aristolochia serpentaria.

See number 569.

573 [RaFinesque, C. S.] Medical specific for the consumption. Atkinson's Saturday Evening Post, vol. $\mathrm{x}$, whole number 492, p. [4], column [7], Philadelphia, January 1, 1831.

An advertisement, marked "Nov. 13-tf."

The same occurs in the issue for January 22, 1831, p. [4], column [6].

574 [RAFInesque, C. S.] Medical Specific, for the consump- 
tion. Atkinson's Saturday Evening Post, vol. $\mathrm{x}$, whole number 496, p. [3], column [7], Philadelphia, January 29, 1831.

An advertisement, marked, "Jan. 29-tf."

575 [RAFinesQue, C. S.] The Mexicans in 1830, by a Mexican citizen. No. II.-Mexican politics. Atkinson's Saturday Evening Post, vol. x, whole number 499, p. [1], columns [2-4], Philadelphia, February 19, 1831.

Part No. 1 of this article probably appeared in the issue for February 5 or 12 , copies of which were not seen by the writer.

See numbers 577, 579, and 580.

576 [Rafinesque, C. S.] Medical Specific For the Consumption. Atkinson's Saturday Evening Post, vol. x, whole number 501, p. [3], column [6], Philadelphia, March 5, 1831.

An advertisement, marked "March 5-tf."

The same occurs in the issue for March 19, p. [4], column [6] ;

March 26, p. [4], column [6] ;

April 2, p. [4], column [7];

April 16, p. [4], column [6] ;

April 23, p. [4], column [4]; and

April 30, p. [4], column [7].

See number 583 .

577 [Rafinesoue, C. S.] The Mexicans in 1830, by a Mexican citizen. No. III.-Mexican resources. Atkinson's Saturday Evening Post, vol. x, whole number 501, p. [1], columns [3-6], Philadelphia, March 5, 1831.

In the issue of the Post for April 16, 1831, occurred the following advertisement: "Mexico in 1830. Just published in pamphlet form, Sketches of the Mexicans in 1830, embracing views of the population, politics, religion, manners and resources of this nation. For sale at the office of the Saturday Evening Post. Price 6r/4 cts. April 2-tf." The advertisement however does not appear in the issue for April 2, 1831. The issue for April 9, 1831, has not been seen by the writer.

See numbers 575,579 , and 580 .

578 [RAFINESQUE, C. S.] School of flora, From the Medical Flora of the United States. Atkinson's Saturday Evening Post, vol. x, whole number 503, p. [4], column [3], Philadelphia, March $19,1831$.

Describes and figures Monarda coccinea.

See number 586.

579 Rafinesque, C. S.: | The Mexicans | in 1830. | - 
written by Prof. C. S. Rafinesque, / communicated by a Mexican citizen, | and first inserted in the | Saturday Evening Post and the Casket. | Philadelphia, February, 1831. $|=|$

Pamphlet, octavo in size, $6 \mathrm{mo}$ in fold, pp. [i-ii, 1], 2-10. The text follows the title and is in two columns to the page. Pages [i-ii] are blank. The copy seen by the writer is in the library of the Missouri Botanical Garden, St. Louis, and bears the legend: "G. Engelmann, from A. De Candolle, Geneve, Octob[er], 1857."

This pamphlet is made up from the type used in the article which appeared in the April, 1831, number of THE CAsker. Pages 2 to 9 inclusive correspond exactly with pages 158 to 165 inclusive, while pages [1] and 10 have been adjusted from pages 157 and 166 respectively, in order to make two short even length columns to each page.

Rafinesque in his Life of Travels, p. 90, says: "At New York *** I met here Mr. Ismar lately from Mexico, who furnished me some materials on this interesting country, by help of which and others, I published afterwards in February, 1831, my pamphlet on Mexico, called the Mexicans in 1830."

There will be noticed a discrepancy in statements or dates. The title states that the pamphlet was first issued in The Casket. The date on the pamphlet is February, 1831, while the date of The Casket in which the article appeared is April, 1831. Evidently issues are not according to dates.

See numbers 575,577 , and 580 .

580 R. [AFINESQUE], C. S. The Mexicans, in 1830, by a Mexican citizen. Atkinson's Casket [or] Gems of Literature, Wit and Sentiment, Philadelphia, April, 1831, no. 4, pp. 157-166.

After a short introduction the information is given in three parts: No. I.-Mexican population; No. II.-Mexican politics; No. III.-Mexican resources. Rafinesque states in the introduction that this article is from ample sketches extracted from Spanish manuscript.

See numbers 575, 577, and 579.

581 Rafinesque, C. S. On the Lobelia and sesamum. Atkinson's Saturday Evening Post, vol. x, whole number 522, p. [3], columns [5-6], July 30, 1831.

582 [Rafinesque, C. S.] Medical Specific for the Consumption. Atkinson's Saturday Evening Post, vol. x, whole number 517, p. [4], column [6], June 25, 1831.

An advertisement, marked June 4-tf. The same with a differently set heading occurs in the issue for July 30, 1831, p. [4], column [5] ; August 20, 1831, p. [4], column [4] ; August 6, 1831, p. [4], column [5] ; August 13, 1831, p. [4], column [7]; September 24, 1831, p. [4], column [7]; 
October 15, 1831, p. [4], column [6]; October 22, 1831, p. [4], column [6] ; November 12, 1831, p. [4], column [6] ; November 26, 1831, p. [4], column [6]; December 3, 1831, p. [4], column [6]; December 17, 1831, p. [4], column [6]; and December 31, 1831, p. [4], column [6].

See number 577.

583 Rafinesque, C. S. School of flora. From the Medical Flora of the United States. Atkinson's Saturday Evening Post, vol. x, whole number 524, p. [4], column [3], August 13, 1831.

Describes and figures Statice caroliniana.

See number 592.

584 RAFINESQUE, C. S. School of flora, from the medical flora of the United States. Atkinson's Saturday Evening Post, vol. $\mathrm{x}$, whole number 534, p. [4], columns [2-3], Philadelphia, October 22, 1831.

Describes and figures Nymphea odorata.

See number 594.

585 Rafinesque, C. S. School of Flora. From the Medical Flora of the United States. Atkinson's Casket, [or] Gems of Literature, Wit and Sentiment, Philadelphia, January, 1831, no. 1, pp. 43-44.

Describes Sanguinaria canadensis, giving cut of the species.

586 Rafinesque, C. S. School of flora. From the Medical Flora of the United States. Atkinson's Casket, [or] Gems of Literature, Wit and Sentiment, Philadelphia, February, 1831, no. 2, pp. 89-90.

Describes Monarda coccinea, giving a cut of the species.

See number 578 .

587 RAFinesque, C. S. School of flora. From the Medical Flora of the United States. Atkinson's Casket, [or] Gems of Literature, Wit and Sentiment, Philadelphia, March, 1831, no. 3, pp. 134-135.

Describes Nelumbium luteum, giving a cut of the species.

588 Rafinesque, C. S. 'School of flora. From the Medical Flora of the United States. Atkinson's Casket, [or] Gems of Literature, Wit and Sentiment, Philadelphia, April, 1831, no. 4, p. 187.

Describes Illicium floridanum, giving a cut of the species.

589 RaFinesque, C. S. School of flora. From the Medical Flora of the United States. Atkinson's Casket, [or] Gems of Lit- 
erature, Wit and Sentiment, Philadelphia, May, 1831, no. 5, pp. 235-236.

Describes Panax quinquefolium, giving a cut of the species.

590 Rafinesoue, C. S. School of flora. From the Medical Flora of the United States. Atkinson's Casket, [or] Gems of Literature, Wit and Sentiment, Philadelphia, June, 1831, no. 6, p. 283.

Describes Pyrola maculata, giving a cut of the species.

591 Rafinesque, C. S. School of flora. From the Medical Flora of the United States. Atkinson's Casket, [or] Gems of Literature, Wit and Sentiment, Philadelphia, July, 1831, no. 7, p. 332.

Describes Scutellaria lateriflora, giving a cut of the species.

592 RAFINESQue, C. S. School of flora. From the Medical Flora of the United States. Atkinson's Casket, or Gems of Literature, Wit and Sentiment, Philadelphia, August, 1831, no. 8, p. 379.

Describes Statice caroliniana, giving a cut of the species.

See number 583.

593 [RAFinesque, C. S. School of flora.] Atkinson's Casket, or Gems of Literature, Wit and Sentiment, Philadelphia, September, 1831, no. 9, pp. 423-424.

Gives some general remarks on leaf fungi, Aecidium, spotted apples. Describes Agaricus surrectus, giving figure, and proposes the same as a new species.

594 Rafinesque, C. F. [C. S.] School of flora, from the Medical Flora of the United States. Atkinson's Casket, or Gems of Literature, Wit and Sentiment, Philadelphia, October, 1831, no. 10, pp. $476-477$.

Describes Nymphea odorata, giving a cut of the species.

See number 584.

595 RaFinesQue, C. S. School of flora. From the Medical Flora of the United States. Atkinson's Casket, or Gems of Literature, Wit and Sentiment, Philadelphia, November, 1831, no. 11, p. 514 [526].

Describes Chelone glabra, giving a cut of the species.

596 [RAFINESQUe, C. S.] School of flora. From the Medical Flora of the United States. Atkinson's Casket, or Gems of Literature, Wit and Sentiment, Philadelphia, December, 1831, no. 12, p. 573.

Describes Spigelia marilandica, giving a cut of the species. 
597 [RAFinesque, C. S.] School of flora. From the Medical Flora of the United States. Atkinson's Casket, or Gems of Literature, Wit and Sentiment, Philadelphia, January, 1832, no. 1, pp. 42-43.

Describes and figures Lobelia inflata.

598 Rafinesque, Professor [C. S.] School of flora. From the Medical Flora of the United States. Atkinson's Casket, or Gems of Literature, Wit and Sentiment, Philadelphia, February, 1832, no. 2, p. 91.

Describes and figures Pterospora andromedea.

599 Rafinesque, Professor [C. S.] School of flora. From the Medical Flora of the United States. Atkinson's Casket, or Gems of Literature, Wit and Sentiment, Philadelphia, March, 1832, no. 3, p. 139.

Describes and figures Leontodon taraxacum.

600 Rafinesquf[E], Professor [C. S.] School of flora. From the Medical Flora of the United States. Atkinson's Casket, or Gems of Literature, Wit and Sentiment, Philadelphia, April, 1832, no. 4, p. 185.

Describes and figures Symphytum officinale.

601 Rafinesque, Professor [C. S.] School of flora. From the Medical Flora of the United States. Atkinson's Casket, or Gems of Literature, Wit and Sentiment, Philadelphia, May, 1832, no. 5, p. 236.

Describes and figures Xanthoxylon fraxineum.

602 Rafinesque, Professor [C. S.] School of flora. From the Medical Flora of the United States. Atkinson's Casket, or Gems of Literature, Wit and Sentiment, Philadelphia, June, 1832, no. 6, p. 282.

Describes and figures Oxalis acetosella.

603 Rafinesoue, Professor [C. S.] School of flora. From the Medical Flora of the United States. Atkinson's Casket, or Gems of Literature, Wit and Sentiment, Philadelphia, July, 1832, no. 7, p. 331.

Describes and figures Trillium latifolium.

604 Rafinesque, Profeissor [C. S.] School of flora. From the Medical Flora of the United States. North American grape 
vines. Atkinson's Casket, or Gems of Literature, Wit and Sentiment, Philadelphia, September, 1832, no. 9, pp. 424-427.

Describes and figures eight varieties, also gives qualities and properties of grape vines and wines.

605 Rafinesque, C. S. ART. III, Retrospective criticism. The Gardener's Magazine and Register of Rural \& Domestic Improvement, conducted by J. C. Loudon, vol. 8, no. 2, pp. 244-248, London, April, 1832.

The article is dated: "Philadelphia, Jan., 1831."

A two line note at the close states: "Our very best thanks are due to Professor Rafinesque for the above most valuable corrections, additions and suggestions."

See number 938.

606 Rafinesque, C. S.: | American florist-second series. | eighteen figures of handsome American and garden flowers - - by C. S. Rafinesque. Philadelphia, 1832.

Broadside, 18 by 22 inches, figures arranged in three rows of six each, and numbered consecutively from 19 to 36 inclusive. The scientific names are placed above the figures and the common names below, presumably the same species represented in the American Florist, a 12mo publication issued in 1832 .

From the press of William Sharpless, printer, No. 2, Decatur street, Philadelphia.

Copies of this publication are in the Library of the Academy of Natural Sciences of Philadelphia and the Fitzpatrick Collection.

See number 607.

607 Rafinesque, C. S. : 36 figures-36 cents. $|=|$ American florist, | containing: | 36 | figures of beautiful or curious | American and garden flowers, plants, | trees, shrubs and vines; | natives of North America, or cultivated $\mid$ in gardens. $|=|$ by $\mathrm{C}$. S. Rafinesque, | Professor of Historical and Natural Sciences. | $-\mid$ Let us teach by Pictures. $\left|\_\right|$Philadelphia. $\mid$1832. $\mid$

Paper $12 \mathrm{mo}$ in size, of 36 leaves, printed on one side only, figures 1-36. The title is on the cover. The index is on the third page of the cover. The fourth page of the cover is blank. The figures are plain and face each other so that, p. [1] is blank; p. [2], reads "Fig. 1"; p. [3], reads "Fig. 2"; pp. [4-5] are blank; p. [6], reads "Fig. 3"; etc. The scientific names of the plants represented are above the figures while the common names are placed below.

The only copy the writer has seen of this rare work is in the Yale 
PLATE XIX

\title{
MONOGRA P H
}

\author{
OF THE
}

\section{FLUVIATILE BIVALVE SHELLS}

\author{
OF THE RIVER OHIO,
}

CONTAINina

ewelve Grenera st Sipty=eight Specirs.

Trunsiated from the French of C. S. Rafinesque, Prof. Bot. and Nat. Hist. in Transylvania University.

PHILADMLPHA :

\section{J. DOBSON, 108 CHESNUT STREET.}

1832.

No. 608. Title to Poulson's translation of Rafinesque's Monograph of the Bivalve Shells of the River Ohio

University Library and is bound at the close of volume II of "Rafinesque's Writings."

See number 606 .

608 RAFINESQUE, C. S.: | A | monograph | of the | fluviatile bivalve shells | of the river Ohio, | containing | Twelve Genera \& Sixty-eight Species. $|-|$ Translated from the French of C. S. 
Rafinesque, Prof. Bot. | and Nat. Hist. in Transylvania University. | - Philadelphia: | J. Dobson, 108 Chesnut street. | 1832. |

Cloth, $12 \mathrm{mo}$ in size, $6 \mathrm{mo}$ in fold, pp. [i-iii], iv-vi, [7-9], 10-72, plate.

This is a translation by C. A. Poulson, dated Philadelphia, October, 1831. It is dedicated to William Hembel. The plate is a frontispiece, giving a cut of Unio verrucosa Raf. All copies that have been seen by the writer have plain plates but it is stated that there are copies with colored plates.

See Plate XIX.

The cover title reads :

Monograph | of the | bivalve shells | of the | river Ohio. |

Copies of this work are in the Library of the State Historical Society of Wisconsin; Library of the Harvard Museum of Comparative Zoölogy; Library of the American Philosophical Society; Library of Harvard University; Library of the Arnold Arboretum; Library of Congress; The John Crerar Library; Library of the Wagner Free Institute of Science; Library of the Historical and Philosophical Society of Ohio; and the Fitzpatrick Collection.

See numbers 344, 363, and 934.

609 RaFinesque, C. S. Visit to Big-Bone Lick, in 1821. By C. S. Rafinesque, Professor of Historical and Natural Sciences, $\mathcal{E c}$. The Monthly American Journal of Geology and Natural Science, conducted by G. W. Featherstonhaugh, vol. 1, no. 8, pp. 355358, February, 1832.

610 RaFinesque, C. S.: | First number, for the spring of 1832. | with two figures, | Melissa and Mammoth cave. | - | atlantic journal, | and | friend of knowledge; | a cyclopedic journal and review | of universal science and knowledge: | historical, natural, and medical arts and sciences : | industry, agriculture, education, and every kind of useful knowledge: | with numerous figures. $|=|$ editor, C. S. Rafinesque, | Professor of Historical and Natural Sciences, and Member of several | learned societies in Paris, Brussels, Vienna, Naples, Bonn, | New York, Philadelphia, Cincinnati, Lexington, \&c. $|=|$ Knowledge is the mental food of man. $|=|$ contents of no. 1. | [31 lines in two columns, listing 26 articles] | - Philadelphia: | published quarterly at the office of the atlantic journal, | no. 59 north eighth street, and Dobson's bookstore, no. 108 | Chesnut street; where subscriptions are received. | Price one dollar per annum in advance, or two dollars for twelve numbers. | William Sharpless, Printer, No. 2 Decatur street. | 1832. | 
AND

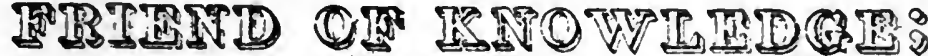

A CYCLOPEDIC JOURNAI, AND REVIEW

OF ENIVERBAL SCIENCE AND KNOWLEDGE:

historical, Natokal, and iedical arts aNd sciences:

INDUSTRY, AGRICOLTORE, EDUCATION, AND EVERY KIND OF OSEFCL KNOTLEDGE:

WITH NUUEROUS FIGCRES.

\section{EDITOR, C. S. RAFINESQUE,}

Professor of Historical and Natural Scienses, and Member of several learned societies in Paris, Brussels, Vienna. Naples, Bonn, New York, Philadelphia, Cincinnati, Lexington, \&jc.

Knowledge is the mental food of man.

CONTENTS OF No. 1.

Art.

Art.
1. Latent Knowledge $\ldots \ldots N$ IFNTS OF No. 1.

2. Free Institutions of Paris

3. First Letter to Champollion :- .

4. American Languages and Nations

5. Allantic Nations of America

6. W. Penn's Dee

7. Clinate of Rochester

8. On Fixed Oils .

9. Sulphur in Trees

10. Melissa or Balm - - .

11. I.etler of Agardh -

13. Jaguars of the United States

14. Conguars of ditto

15. Zoological Letters to Barion. Cuvier

2 17. tucky - Cuinatuefore the Floj 22

6 15. Early Colonies of China - - 26

' 10 19. Scientific Explorers in America and

11 20. The Caves of Ken:ucky - - 27

1) 21 . Genlogical Strata of Obio and Ken-

13 tucky - - - - - 30

14 22. Fold Mines of N. America

15 93 . Plan of a new Trading Voyage $\mathbf{\$ 2}$

16.24 . Allanic Review - $\quad . \quad 34$

is.25. Miscellany - . - - $\$ 55$

1926 "Poem on Kiowledge - $\quad$ - 36

\section{PHILADELPHI.}

PUBLISHED QUARTERI, A T THE OFFICE OF THE ATLANTIC JOURNAL, No. 59 NORTH EIGHTH STREET, AND DOBSON'S BOOKSTORE, No. 108 CHESNUT STREET; WHERE SUBSCRIPTIONS ARE RECEIVED,

Price oNe dollar per annum in alvance, or Tivo dollars for twelve numbers.

William Sharpless, Printer, No. 2 Decatur street.

3852. 
Pamphlet, octavo in size, quarto in fold, pp. 1-36, figure of entrance to Mammoth Cave and figure of Melissa officinalis. The above title is from the cover. Issued March 20, 1832.

See Plate XX.

The inner subtitle reads :

Atlantic journal, | and | friend of knowledge; | a cyclopedic journal and review | of universal science and knowledge: | historical, natural, and medical arts and sciences: | industry, agriculture, education, and every useful information: | with numerous figures. $|=|$ editor, C. S. Rafinesque, | Professor of Historical and Natural Sciences, \& $c$. $|=|$ Vol. 1. Philadelphia, spring of 1832. No. 1. $|=|$ Knowledge is the mental food of man. I - 1

The articles of volume 1 , number 1 , are:

611 [RAFINESQUE, C. S.] Introduction, p. [1].

612 R.[AFINESQUE], C. S. 1. Latent knowledge, pp. 1-2.

613 [RAFinesque, C. S.] 2. Public instruction. Free Institutions of Paris and France, pp. 2-4. This article is signed by Benj. Franklin, jr.

614 Rafinesque, C. S. 3. Philology. First Letter to $\mathrm{Mr}$. Champolion, on the Graphic systems of America, and the Glyphs of Otolum or Palenque, in Central America, pp. 4-6. This article is signed: "Philadelphia, January, 1832."

615 Rafinesque, C. S. 4. American History. Tabular View of the American Generic Languages, and Original Languages, and Original Nations, pp. 6-8. This article is signed: "July 4th, 1829."

616 Rafinesque, C. S. 5. The Atlantic Nations of America, pp. $8-10$.

617 [RAFinesque, C. S.] 6. William Penn's Deed from the Indians in 1685, pp. 10-11.

618 [RAFinesque, C. S.] 7. Meteorology. Climate of Rochester in New York, chiefly based upon the observations and tables of the Genesee Farmer for 1831, pp. 11-12.

619 R. [AFINESQUE], C. S. 8. Agriculture. Results of the Experiments of Recluz on the Fixed Oils, pp. 12-13.

620 R. [AFINESQUE], C. S. 9. Confirmations of the Important Discovery of the property of Sulphur in trees, to destroy all Insects preying on them, pp. 13-14.

621. R.[AFInESQUE], C. S. 10. Horticulture. Melissa Officinalis, or Balm, pp. 14-15. Gives figure. 
622 R. [AFINESQUE], C. S, 11. Botany. Part of a letter from C. A. Agardh, Professor of Botany at Lund, in Szeden, to Prof. C. S. Rafinesque, dated 26th June, 1831. Translated from the French, pp. 15-16. Closes with a paragraph of remarks by C. S. $\mathrm{R}$.

623 RafinesQue, C. S. 12. Selection of twenty-four out of one hundred neze species of Plants of North America, sent to Europe in 1828, by C. S. Rafinesque, pp. 16-18.

624 Rafinesque, C. S. 13. Zoology. On the large Wandering Tygers or Jaguars of the United States, pp. 18-19.

625 R. [AFINESQUE], C. S. 14. On the North American Couguars, p. 19.

626 Rafinesque, [C. S.] 15. Extracts from A Second Series of Zoological Letters written to Baron Cuvier of Paris, by Prof. Rafinesque in 1831, pp. 19-22.

627 Rafinesque, C. S. 16. Description of the Spelerpes or Salamander of the caves of Kentucky, p. 22.

628 RAFINESQUE, C. S. 17. Geology and history. History of China before the flood, pp. 22-26.

629 R. [AFINESQUe], C. S. 18. Early Colonization from China by Sea, p. 26.

630 [RAFInESQUe, C. S.] 19. Scientific explorers in America and Africa, p. 26.

631 Rafinesque, C. S. 20. Geology. The Caves of Kentucky, pp. 27-30.

632 R. [AFINESQUE], C. S. 21. Geological Strata of Ohio and Kentucky, pp. 30-31.

633 R.[AFInESQUe], C. S. 22. Mineralogy. Gold Mines of North America, p. 31.

634 Rafinesque, C. S. 23. Commerce. Plan of a new Trading Voyage, of Industry and Science, pp. 32-34.

635 . [RAFinesque, C. S.] 24. Atlantic review, pp. 34-35. Gives short reviews or statements concerning thirty-three recent publications.

636 [RAfinesque, C. S.] 25. Miscellany, pp. 35-36.

637 R. [AFinesque], C. S. 26. Fragment of a philosophical poem on knowledge, p. 36.

638 RAFinesque, C. S.: | Second number for the summer of 
1832. | with two figures: | altlantic alphabets and Franklin tree. — atlantic journal, | and | friend of knowledge; | a cyclopedic journal and review / of universal science and knowledge: | historical, natural, and medical arts and sciences: | industry, agriculture, education and every kind of useful information: | with numerous figures. | - editor, C.S. Rafinesque, | Professor of Historical and Natural Sciences, and Member of several learned Societies in Paris, Brussells, Vienna, Naples, Bonn, New-York, Philadelphia, Cincinnati, Lexington, \&c. $|-|$ Knowledge is the mental food of man. $|-|$ contents of no. 2. | [43 lines in two columns, listing 31 articles] | - Philadelphia: | published quarterly at the office of the atlantic jour- | nal, no. 59 north eighth st. and Dobson's bookstore, no. 108 | chesnut st. where subscriptions are received. | Price one dollar per annum in advance, or two dollars for twelve Numbers. | Single Numbers Fifty Cents. | 1832. |

A pamphlet, octavo in size, quarto in fold, pp. [39], 40-82, plate as frontispiece and figure of Franklinia alatama.

The title to the plate reads:

Tabular view | of the compared Atlantic | alphabets \& glyphs | of Africa and America. | - By Prof. C. S. Rafinesque. Philadelphia. 1832. $\mid-1$

A few separates were issued.

The inner subtitle reads:

Atlantic journal, | and | friend of knowledge; | a cyclopedic journal and review $\mid$ of universal science and knowledge:-historical, natural, and medical arts | and sciences:-industry, agriculture, education and every kind of useful | information: | with numerous figures. | - | editor, C. S. Rafinesque, | Professor of Historical and Natural Sciences, \&c. $1=\mid$ Vol. I.] Philadelphia, Summer of 1832. [No. 2. $\mid-1$ Knowledge is the mental food of man. $1=1$

The articles in this number are:

639 [RAFINESQUE, C. S.] 1. article. Cheap books, pp. [39] -40. This article is signed by "Benj. Franklin, junr."

640 Rafinesque, C. S. 2. Philology. Second Letter to Mr. Champollion on the Graphic Systems of America, and the Glyphs of Otolum or Palenque, in Central America.-Elements of the Glyphs, pp. 40-44. Signed: "Philadelphia, February, 1832."

641 R. [AFINESQUE], C. S. 3. Primitive Origin of the English Language, pp. 44-48.

642 Rafinesque, C. S. 4. Anthropology. The Fundamen- 
tal Base of the Philosophy of Human Speech, or Philology and Ethnology, pp. 48-51. This article is dated: "Philadelphia, May 1831."

643 Rafinesque, C. S. 5. American history. On the Zapotecas and other Tribes of the State of Oaxaca, pp. 51-56.

644. Rafinesque, C. S. 6. History and Zoology. The Domestic Animals of Mankind and the American Nations, pp. 56-61.

645 Rafinesque, C. S. 7. Zoology. On the Moles of North America and two new species from Kentucky, pp. 61-62.

646 Rafinesque, C. S. 8. Description of a New Otter, Lutra Concolor from Assam in Asia, p. 62. This article is signed: "Philadelphia, 27 March, 1832", and the postscript: "May 1832."

647 R. [AFINESQUE], C. S. 9. Couguars of Oregon, pp. 62-63.

648 R.[AFINESQUE], C. S. 10. Ornithology.-Description of a new Eagle from South America, Aquila dicronyx or Macarran Eagle, p. 63.

649 R.[AFinesque], C. S. 11. Erpetology.-On the Salamander of the hills of East Kentucky. S. lurida, pp. 63-64.

650 Rafinesque, C. S. 12. Description of two new genera of Soft Shell Turtles of North America, pp. 64-65. This article is signed: "New-York, October, 1816."

651 Rafinesque, C. S. 13. Geology and Oryctology. Extracts of a Series of Geological Letters to Prof. Al. Brongniart, President of the Geological Society of Paris; by Prof. C. S. Rafinesque, pp. 65-67.

652 RaFInESQUe, C. S. 14. Remarks on the Silicious Fossils of North America, pp. 67-69. This article is signed: "Philadelphia, 2d April, 1832."

653 [RAFInesque, C. S.] 15. Remarks on the Geodes and Geodites, pp. 69-70.

654 [Rafinesque, C. S.] 16. On the Cavulites and Antrosites, pp. 70-71.

655 Rafinesque, C. S. 17. On the Genera of fossil Trilobites or Glomerites of North America, pp. 71-73. Dated: "Philadelphia, May, 1832."

656 Rafinesque, C. S. 18. On the Salses of Europe and America, pp. 73-74. 
657 Rafinesque, C. S. 19. On the Lamellites N. G. of American Fossils, p. 74.

658 RafinesQue, C. S. 20. Physical Geography. Licks and Sucks of Kentucky, pp. 74-77.

659 [RAFInesque, C. S.] 21. The two Highest Mountains of America.-By Pentland, p. 77. Signed by: "Tellus."

660 [RAFinesgue, C. S.] 22. Scientific Explorers of North America, pp. 77-78. Signed by: "Tellus."

661 [RAFinesque, C. S.] 23. Botany and Horticulture. Extracts of a letter from Dr. John Torrey of Neze York, to Prof. Rafinesque of Philadelphia, March 1832, p. 78. This article is Rafinesque's only as editor.

662 R. [AFINESQUE], C. S. 24. Description of a new cherry tree from the Oregon Mountains, p. 78.

663 Rafinesque, C. S. 25. Account of 2 N. Sp. of Dionea or Venus fly trap, pp. 78-79.

664 RaFinesque, C. S. 26. New Plants from Bartram's Botanic Garden, pp. 79-80. Gives figure of Franklinia alatama.

665 [Rafinesque, C. S.] Archeology. 27. Some Antiquities of Tennessee. By M. Rhea, pp. 80-81. The introductory paragraph by Rafinesque. 81.

666 R. [AFINESQUE], C. S. 28. Some Antiquities of Ohio, p.

667 R. [AFINESQUE], C. S. 29. Economy or science of wealth, p. 81.

668 [RAFinesQue, C. S.] 30. Atlantic review, p. 82.

669 [RAFINESQUE, C. S.] 31. Scientific news, p. 82.

670 RAFinESQUE, C. S.: | Atlantic journal | and | friend of knowledge; | a cyclopedic journal and review | of universal science and knowledge: | historical, natural, and medical arts and sciences: | industry, agriculture, education and every kind of useful information: |- | editor, C. S. Rafinesque, | Professor of Historical and Natural Sciences, and Member of several learned Societies | in Paris, Brussels, Vienna, Naples, Bonn, Nere-York, Phila- | delphia, Cincinnati, Lexington, \&c. $|-|$ Knowledge is the mental food of man. $\mid$ - | Vol. I. Philad. September, 1832. [Extra of No. 3.1 - 
Pamphlet, octavo in size, quarto in fold, pp. [83]-90. The above is the inner subtitle, text follows. No cover title has been seen.

The' articles are :

671 [Rafinesque, C. S.] Notice, p. [83].

672 [RAFINesQUe, C. S.] Contents for this year, pp. [83]85.

673 [RAFInESQue, C. S.] Scientific Travels of the Editor in 1832, p. 85.

674 RAFinesque, C. S. The Primitive Black Nations of America, pp. 85-86.

675 [RAFInesQue, C. S.] Employment of Wealth, pp. 8688. Signed by "Benj. Franklin, Junr." 89.

676 R. [AFINESQUE,] C. S. Savings' Banks at Baltimore, p.

677 [RAFINESQUe, C. S.] Plan of an improved Savings Institution, pp. 89-90.

678 [RAFINESQUE, C. S.] List of agents for this journal, to whom subscriptions may be paid, p. 90 .

679 RAFINESQUE, C. S.: | Atlantic journal | and | friend of knowledge; | a cyclopedic journal and review | of universal science and knowledge: | historical, natural, and medical arts and sciences : | industry, agriculture, education and every kind of useful information: | with numerous figures. $|-|$ editor, C. S. Rafinesque, | Professor of Historical and Natural Sciences, \&c. I $=\mid$ Vol. I.] Philadelphia, Autumn of 1832. [No. 3. $\mid-1$ Knowledge is the mental food of man. $\mid=1$

Pamphlet, octavo in size, quarto in fold, pp. [91]-122, figures 2. The above is the inner subtitle, text follows. No cover title has been seen.

The articles are:

680 [RAFINESQUE, C. S.] 1. Analysis of Fellenberg's System of Education, pp. [91]-93.

681 [RAFinesque, C. S.] 2. Taxes on Knowledge, pp. 9395. Signed by "B. Franklin, Jr."

682 [RAFinesque, C. S.] 3. Analysis of the Philosophy of Pythagoras as promulgated 2400 years ago, pp. 95-98. Signed by "Benj. Franklin, Junr."

683 R. [AFInesque], C. S. 4. The American Nations and Tribes are not Jews, pp. 98-99. 
684 Rafinesque, C. S. To the Rev. Ethan Smith, Pastor of Poultney in Vermont, pp. 99-101. A communication giving reasons to support the contention that the Indians are not descendants of the Jews. Signed "Philadelphia August 1829."

685 RaFinesque, C. S. 5. The Cradle of Mankind or the Imalaya Mountains, pp. 101-105.

686 R.[AFINesQUe], C. S. 6. Oreology. Relative Age of Mountains, p. 105.

687 RaFinesQue, C. S. 8. Geological Survey of the Alleghany Mountains of Pennsylvania, in 1818, from West to East, pp. 105-109.

688 RAFINESQUE, C. S. 8. Description of some of the fossil teeth found in a Cave in Pennsylvania, pp. 109-110. Gives figure of Odocoileus speleus.

689 RAFINESQUE, C. S. 9. Remarks on the Monthly Journal of Geology and Natural Science of G. W. Featherston[h]augh, for May 1832, (but only published in July.), pp. 110-114.

690 R. [AFINESQUE], C. S. 10. On the false Rhinoceroides of Featherston $[\mathrm{h}]$ augh and Harlan, pp. 114-115.

691 [RAFINESQUE, C. S.] 11. Coal Mines of Nantico in the Alleghany Mountains. By Dr. Powell, p. 115.

692 R.[AFINESQUE], C. S. 12. Geology of the Feroe Islands, p. 116.

693 RAFinesque, C. S. 13. Arcibites Rhombifera, a new Encrinite, from the Cabinet of Dr. Cohen, of Baltimore, p. 116.

694 RAFINESQUE, C. S. 14. Lucilites Nigra, a new univalve fossil Shell, from the Alleghany Mountains of Pennsylvania, pp. $116-117$.

695 R.[AFinesoue], C. S. [Review of] 15. American History-Ancient Chronology of the Onguys or Iroquois. By David Cusick, pp. 117-118.

696 R.[AFinesoue], C. S. 16. American Philology.-Vocabulary of the Yarura Language, p. 118.

697 RaFinesque, C. S. 17. Botany-New and rare plants of Maryland near Baltimore, p. 119.

698 Rafinesque, C. S. 18. Six New Firs of Oregon, pp. 119-120. 
699 Rafinesque, C. S. 19. On the 3 N. Sp. of Clintonia, p. 120.

700 Rafinesque, C. S. 20. On 3 N. Sp. of Eriocaulon, p. 121.

701 Rafinesque, C. S. 21. Erpetology.-On 3 New Water Salamanders of Kentucky, p. 121.

702 Rafinesque, C. S. 22. Conchology.-A New Tubular fresh water shell of the Alleghany mts., pp. 121-122. Gives cut of Psephides paradoxa.

703 R.[AFInesQue], C. S. 23. Fossils of Sherman Creek, p. 122.

704 R.[AFInesQue], C. S. 24. Atlantic Review, p. 122.

705 RAFinesQue, C. S.: | Atlantic journal | and | friend of knowledge; | a cyclopedic journal and review | of universal science and knowledge: | historical, natural, and medical arts and sciences: | industry, agriculture, education and every kind of useful information : | with numerous figures. | - editor, C. S. Rafinesque, | Professor of Historical and Natural Sciences, \&c., | =| Vol. I.] Philadelphia, Winter of 1832. [No. 4. $\mid-1$ Knowledge is the mental food of man. $\mid=1$

Pamphlet, octavo in size, quarto in fold, pp. [123]-154, figure. The above is the inner subtitle, text follows. No cover title has been seen.

706 [RAFinesque, C. S.] Article 88. - Principles of Jacotot or his system of Instruction, pp. [123]-124. Signed by "Benj. Franklin, Jurn."

707 [RAFINESQUE, C. S.] 89. Impediments to Knowledge, Literature and Science, in the United States, pp. 124-126. Signed by "B. Franklin, Junr."

708 R.[AFinesque], C. S. 90. Ancient Monuments of Central Pennsylvania by Major Adlum, pp. 126-127.

709 [RAFINESQUE, C. S.] 91. Antiquities of East Virginia by Col. Mead, p. 127.

710 [RAFINESQUE, C. S.] 92. American History. The last Indians of Virginia, by Col. D. Mead, pp. 127-128.

711 RaFinesque, C. S. 93. The Last Indians of New-Jersey, p. 128.

712 Rafinesque, C. S. 94. Description of an ancient Mexican Historical manuscript, pp. 128-130. 
713 Rafinesque, C. S. 95. Peruvian history. Table of the successive Dynasties and Incas of Peru, pp. 130-132.

714 RafinesQue, C. S. 96. American Languages. Wahtani or Mandan, pp. 132-133.

715 Rafinesque, C. S. 97. Languages of Oregon. Chopunish and Chinuc, pp. 133-134.

716 [RAFinesque, C. S.] 98. Geology of Natchez, p. 135.

717 [RAFInESQUE, C. S.] 99. Geological Remarks between Buffaloe in New York and Pittsburg, in Pennsylvania. By David Thomas, pp. 135-137.

718 R. [AFINESQUE], C. S. 100. Oryctology. Vulgar names of fossils and petrifactions in North America, p. 137.

719 Rafinesque, C. S. 101. Ancient Volcanoes of North America, pp. 137-140.

720 R.[AFINESQUE], C. S. 102. Mineralogy. Oolites of North America, pp. 140-141.

721 R. [AFINESQUE], C. S. 103. The Fishes of the United States, pp. 141-142.

722 Rafinesque, C. S. 104. New Fossil Shells of Pennsylvania, by C. S. Rafinesque, pp. 142-143. With cut illustrating seven species.

723 R. [AFINESQUe], C. S. 105. Stratipora and Flexulites N. G., p. 143.

724 R. [AFINESQUe], C. S. 106. New Lizard from Kentucky, pp. 143-144.

725 RAFInesque, C. S. 107. Twenty new genera of plants from the Oregon Mountains \&c., pp. 144-146.

726 Rafinesque, C. S. 108. Account of 32 N. Sp. of plants from Florida, pp. 146-148.

727 R.[AFINESQUE], C. S. 109. On 3 sp. of Typha, pp. 148149.

728 Rafinesque, C. S. 110. Two New Genera of Umbelliferous Plants from Kentucky, p. 149.

729 Rafinesque, C. S. 111. On 12 N. Sp. of Plants from Illinois, \&c., pp. 149-151.

730 Rafinesque, C. S. 112. On 17 N. Sp. of Plants from Upper Canada, \&c., pp. 151-152. 
731 Rafinesque, C. S. 113. Vernasolis a New Genus by C. S. Rafinesque, p. 152.

732 RaFinesque, C. S. 114. Lophactis N. G. by C. S. Rafinesque, pp. 152-153.

733 R. [AFINESQUe], C. S. 115. On 4 N. Sp. of North American Tulips by C. S. R., p. 153.

734 RaFinesque, C. S. 116. New Plants of the Alleghany Mts., pp. 153-154.

735 Rafinesque, C. S. 117. Conchology. Two New Bivalve Fluviatile Shells of S. America, By C. S. Rafinesque, p. 154.

736 Rafinesque, C. S. 118. Odatelia N. G. of American Bivalve fuviatile shell, by C. S. Rafinesque, p. 154.

- 737 RaFinesque, C. S.: $5 \mid$ fifth number for the spring of 1833. Price 50 cents each number, or One Dollar per anmum. $1=\mid$ atlantic journal $\mid$ and | friend of knowledge; | a quarterly journal of $\mid$ historical and natural sciences, useful knowledge, \&c. | with figures. | - by C. S. Rafinesque, | Professor of Historical and Natural Sciences, Member of many learned Socie- 1 ties in America and Europe, Author of many Works, \&c. \&c. $\mid$ - Knowledge is the mental food of man. $|-|$ Vol. I. Philadelphia, Spring of 1833. No. 5. $|-|$

Pamphlet, octavo in size and fold, pp. [155]-170.

The articles are:

738 R.[AFInesque], C. S. 119. American Travellers, pp. [155]-157.

739 [RAFinesque, C. S.] 120. Reward of Merit, p. 157.

740 Rafinesque, C. S. 121. Alleghanies Mountains, pp. $157-161$.

741 R.[AFinesQue], C. S. 122. The Patagons, pp. 161-163.

742 [Rafinesque, C. S.] 123. N. G. Cauloma. Raf., p. 163.

743 R. [afinesque], C. S. 124. Principles of the Philosophy of new Genera and new species of Plants and Animals, pp. 163-164.

744 [Rafinesque, C. S.] 125. N. G. Scadianus. Raf., pp. 164-165.

745 Rafinesque, C. S. 126. On 3 N. G. of Land Shells from Buenos Ayres in South America, p. 165.

746 [RAFinesque, C. S.] 127. On 5 New Fresh Water Shells, of Bengal and Assam in Asia, pp. 165-166. 
747 [RAFinesque, C. S.] Commercial Enterprise, p. 166.

748 [RAFinesQue, C. S.] Notice, p. 166.

749 Rafinesque, C. S. Account of the Botanical Collections of Professor C. S. Rafinesque, pp. 167-170. Signed "No. 59, North Eighth-St., Philadelphia, April, 1833."

750 [RAFINESQUE, C. S.] Professor Rafinesque's Iconography and Illustrations of 32 years Travels, p. 170.

751 RAFINESQUE, C. S.: | Nr. 6. | sixth number for the summer of 1833. | Price 50 cents each number, or One Dollar per annum. $|=|$ Atlantic journal $\mid$ and | friend of knowledge, | a quarterly journal of $\mid$ historical and natural sciences, useful knowledge, \&c. | with figures. | | by C. S. Rafinesque, | Professor of Historical and Natural Sciences, Member of many learned Societies in America and Europe, Author of many Works, \&c. \&c. $1-\mid$ Knowledge is the mental food of man. $|-|$ Vol. I. Philadelphia, Summer of 1833 . No. 6. $\mid-$

Pamphlet, octavo in size and fold, pp. [171]-186.

The articles are:

752 R.[AFinesque], C. S. Article 130. Epidermic Varieties of Mankind, pp. [171]-172.

753 [RAFINESQUE, C. S.] 131. Complexions of Mankind, \&c., pp. $172-173$.

754 [RAFINESQUE, C. S.] 132. Affinities of the English Language with the African Languages and Dialects of Egypt. \&c., pp. 173-175.

755 [RAFINESQUE, C. S.] 133. Sorex dichrurus. N. Sp. of Shrew, pp. 175-176.

756 [RAFINESQUE, C. S.] 134. Florula Texensis. Dicotyl. N. Sp., pp. 176-179.

757 [RAFINESQUE, C. S.] 135. G Dodecatheon or Meadia, pp. 179-180.

758 [RAFInesque, C. S.] 136. New Amer. Subterranean Plants, pp. 180-182.

759 [Rafinesque, C. S.] 137. Pleuradena Coccinea. N. G. of Mexican Shrub, from Bartram's Garden, p. 182.

760 [RAFINESQUE, C. S.] 138. Orospodias Corymbosa or Wild Cherry, of Oregon Mountains, p. 182.

761 RAFINESQUE, C. S.: | Incombustible architecture, | Or 
Fire Proof Buildings of all Kinds, | built as cheap | as any combustible buildings. | by C. S. Rafinesque, | Professor of many Sciences, Architect, Draftsman, \&c. $|=|$, pp. 183-186.

762 RAFINESQUE, C. S. : | Nr. 7. | seventh number for the autumn of 1833 | Price 50 Cents each number, or One Dollar per annum. $|=|$ atlantic journal $\mid$ and $\mid$ friend of knowledge; $\mid$ a quarterly journal of $\mid$ historical and natural sciences, useful knowledge, \&c. | with figures. | - | by C. S. Rafinesque, | Professor of Historical and Natural Sciences, Member of many learned Socie- $\mid$ ties in America and Europe, Author of many Works, \&c. \&c. $|-|$ Knowledge is the mental food of man. $|-|$ Vol. I. Philadelphia, Autumn of 1833. No. 7. $\mid-1$

Pamphlet, octavo in size and fold, pp. [187]-202.

The articles are:

763 [RafinesQue, C. S.] Article 140. Scientific Travels of C. S. Rafinesque, in 1833, pp. [187]-188.

764 Rafinesoue, C. S. 141. Physical Geography. Elevations of land and water, mountains and hills in the State of New York, pp. 188-191.

765 [RAFInESQUe, C. S.] 142. Geology. Some essential views of Geology, by Dr. Hibbert and Rafinesque, pp. 191-195.

766 RafinesQue, C. S. 143. American History. Some remarks on the Ruins of Otolum near Palenque-By C. S. Rafinesque, pp. 195-197.

767 R. [AFINeSQUe], C. S. 144. History of Austral America, pp. 197-198.

768 R.[AFINESQUE], C. S. 145. Chontal or Tzendal vocabulary, p. 198.

769 R.[AFINESQUe], C. S. 146. Gypsies of America, pp. 198199.

770 R. [AFINESQUE], C. S. 147. Botany, N. G. Ygramela and Peltimela, p. 199.

771 Rafinesque, C. S. 148. On the Custard-apples or Aunona trilobd and glabra, pp. 199-200.

772 R. [AFINESQUE], C. S. 149. Ecpexis N. G. of Water Plants, p. 200.

773 R. [AFInESQUe], C. S. 150. Substitutes for Tobacco, pp. 200-201. 
774 R.[AFINESQUE], C. S. 151. Huge Water Volcano, pp. 201-202.

775 RAFINESQUE, C. S. 152. Improvements in Navigation, p. 202.

776 [Rafinesque, C. S.] Chemical manufacture, of Professor Rafinesque, p. 202.

777 Rafinesque, C. S.: | Nr. 8. | eighth number for the winter of 1833. | Price 50 Cents each number, or One Dollar per annum. $|=|$ atlantic journal | and | friend of knowledge; | a quarterly journal of $\mid$ historical and natural sciences, useful knowledge, \&c. | with figures. | - by C. S. Rafinesque, | Professor of Historical and Natural Sciences, Member of many learned Socie- $\mid$ ties in America and Europe, Author of many Works, \&c. \&c. $|-|$ Knowledge is the mental food of man. $|-|$ Vol. I. Philadelphia, Winter of 1833. No. 8.

Pamphlet, octavo in size, quarto in fold, pp. [205]-212.

The articles are:

778 Rafinesque, C. S. 154. Meteorology. The Luminous Meteors of 1833, pp. [205]-206.

779 RaFinesque, C. S. 155. Botany. Chronological Index of the principal Botanical Works and Discoveries published by $C$. S. Rafinesque, pp. 206-208.

780 [RAFinesQue, C. S.] 155. Geography. Discovery of Enderby Land in the Austral Ocean, p. 208-209.

781 R.[AFinesque], C. S. 156. Geology, and physical features of the Atlantic plains of North America, by C.S. R., pp. 209-211.

782 [RaFinesque, C. S.] 157. American Travels published in 1833, p. 211.

783 [RAFineSQUE, C. S.] Valedictory, pp. 211-212.

784 RAFinesQue, C. S. The book of knowledge, p. 212.

785 RAFinesoue, C. S.: | Atlantic journal, | and | friend of knowledge. | in eight numbers. | ConTAINING about 160 original articles and tracts on Natural and | Historical Sciences, the Description of about 150 New Plants, | and 100 New Animals or Fossils. Many Vocabularies of Langua- $\mid$ ges, Historical and Geological Facts, \&c. \&c. \&c. | - | by C. S. Rafinesque, A. M... Ph. D. | Professor of Historical and Natural Sciences, Member of 
seve- | ral learned societies in Europe and America, \&c. $\mid-1$ Knowledge is the mental food of man. | _ | Figures. | [8 lines in two columns.] | - Philadelphia: | 1832-1833. | ('Two dollars.) |

Octavo in size, quarto in fold, pp. [i-iv], 1-212, plate, figures. Issued in ten numbers, there being numbers 1 to 8 and extra of number 3 and extra of number 6. Extra of number 6 however is not paged with the volume but separately, pp. 1-80. Its title is usually quoted as Herbarium Rafinesquianum, \&c.

Copies of the Atlantic Journal are in the Library of Harvard Museum of Comparative Zoölogy; Library of Harvard University; Library of the Arnold Aboretum; Library of the New York Botanical Garden; New York Public Library; Yale University Library; Library of the British Museum; Library of the Missouri Botanical Garden; Library of the State Historical Society of Wisconsin (numbers 1 and 2, only); Library of Congress; The Newberry Library (The Ayer Collection, numbers 1-7 only); Library of the Historical Society of Pennsylvania; and the Fitzpatrick Collection.

786 Rafinesque, C. S.: | Atlantic Journal.-Extra of No. 6. | - herbarium | Rafinesquianum. $|\longrightarrow|$ Prodromus. - pars prima. | rarissim. plant. nov. $|=|$ herbals; | or | botanical collections | of | C. S. Rafinesque, | Professor of Botany, \&c. \&c. \&c. | - | first part. | Very Rare New Plants, chiefly from Oregon, Texas, Arkan- $\mid$ sas, Missouri, Illinois, Kentucky, 'Tennessee, Alabama, Florida, Apalachian, and Alleghany Mountains, in North | America. | Besides Russia, Siberia, Syria, Arabia, Candia, Sicily, Italy, | Egypt, Magellania, \&c. elsewhere. | Collected or acquired between 1800 and 1832. | - the labor of a whole life! $|=|$ Philadelphia: | 1833. | Price One Dollar. |

Pamphlet, 16mo in size, octavo in fold, pp. [1-3], 4-80. Pages 1-32 are entitled first part; pp. 33-48, second part; pages 49-64 are entitled "third part" and pages 65-80 are "third part continued."

A copy of this pamphlet is in the Library of the New York Botanical Garden; also the Library of the Arnold Arboretum (pp. 1-48 only).

James Britten ${ }^{50}$ states that there are copies in the British Museum and Kew libraries which contain subsequent parts. which include pages 49-64 and $65-80$ respectively.

Contents :

787 Preamble, p. [2].

788 Account of the botanical collections of Professor C. S. Rafinesque, pp. [3]-10.

${ }^{50}$ Britten, The Journal of Botany, vol. 38, pp. 224-225, 1900. 
789 Professor Rafinesque's Iconography and Illustrations of 32 years Travels, p. 10.

790 Principles of the Philosophy of new Genera and new species of Plants and Animals, pp. 11-12.

791 Natural Classification of Plants, pp. 12-15.

792 Extracts from Botanical Letters to Decandole, Agardh, and Arnott, in 1830, 31, 32, \& 33, pp. 16-20.

793 I. Florula Texensis. Dicotyl. N. Sp. New Dicotyle Plants of Texas and Arkanzas, pp. 20-25.

794 Nov. Plant. Texensis Ec. Monocot., pp. 25-26.

795 II. G. Dodecatheon or Meadia, pp. 26-29.

796 III. 2 N. Sp. of Vernonia, 50 cts., pp. 28-29.

797 IV. G. Kuhnia, revised, pp. 29-30.

798 V. G. Helichroa, Raf. 1825, pp. 30-32.

799 G. Vitis, 36 sp. and 24 varieties, p. 32.

800 Chronological Index of the principal Botanical Works and Discoveries published by C. S. Rafinesque, pp. [33]-37.

801 Index of the Florula Mandanensis of Bradbury and Rafinesque, published in 1817 and in 1820 with notes and additions, pp. 37-41.

802 Monograph of the Species of G. Samolus, in my Herbarium, pp. $41-43$.

803 Genus Cypripedium, pp. 43-44.

804 Genus Spiranthes, pp. 44-45.

805 G. Jeffersonia and Podophyllum, p. 46.

806 1. Fasciculus florula Oregonensis, pp. 46-48.

807 Florula Apalachensis, Dicotyl. Fasciculus I, p. 48.

808 Index to my Autikon Botanikon, 1815-1833, p. 49.

809 Florula Oregonensis, pp. 49-54.

810 Sylva Americana Autikon. Supplement to the Trees and Shrubs of North America, pp. 55-59.

811 Florula Centralis or Illinoensis, pp. 59-63.

812 Description of some new Moncotyle Plants of this Central Region, pp. 64-65.

813 Autikon Botanikon, pp. 65-66.

814 Florula Wasiotana, pp. 66-67.

815 Nova Florula Aleghanica, pp. 67-69.

816 Autikon Maritinum, pp. 69-70.

817 New Genera of Orchideous, pp. 70-74.

818 New Species of N. Amer. Orchideons, pp. 74-77.

819 New Umbelifera, pp. 77-78.

820 Florula Alabamensis and Floridana, pp. 79-80.

821 RAFinesque, C. S. Letter to $M r$. Champollion on the Graphic Systems of America, and the Glyphs of Otolum of Palen- 
que, in Central America. - Elements of the Glyphs. American Antiquities and Discoveries in the West, by Josiah Priest, second edition revised, pp. 118-124, Albany, 1833.

The first edition of Priest's American Antiquities does not contain any articles by Rafinesque.

See numbers $832,844,852,877,889,926,931$, and 932.

822 [RAFINESQUe, C. S.] Ruins of the city of Otolum, discovered in America, of Peruvian origin. American Antiquities and Discoveries in the West, by Josiah Priest, second edition revised, p. 241, Albany, 1833.

Extract from a letter in the body of a paper with the above title and treating of the same subject matter.

See numbers 833, 845, 853, 878, 890, and 927.

823 Rafinesque, C. S. Ancient Languages of the first inhabitants of America. First Letter to Mr. Champollion, on the Graphic Systems of America, and the Glyphs of Otolum or Palenque, in Central America. American Antiquities and Discoveries in the West, by Josiah Priest, second edition revised, pp. 304-309, Albany, 1833.

See numbers 834 and 846.

824 Rafinesque, C. S. Tabular View of the American Generic Languages and Original Nations, by the same Author. American Antiquities and Discoveries in the West, by Josiah Priest, second edition revised, pp. 309-312, Albany, 1833.

This is dated July 4th, 1829. Rafinesque in a postscript says that it was printed in the Evening Post, presumably the Saturday Evening Post of Philadelphia.

See number 835 .

825 [Rafinesque, C. S.] The Atlantic Nations of America. American Antiquities and Discoveries in the West, by Josiah Priest, second edition revised, pp. 312-316, Albany, 1833.

See numbers 836, 847, 854, 879, 891, and 928.

826 RAFinesQUe, C. S. Further accounts of colonies from Europe settled in America. On the Zapotecas, and other Tribes of the State of Oaxaca. American Antiquities and Discoveries in the West, by Josiah Priest, second edition revised, pp. 316-325, Albany, 1833.

See number 837. 
827 Rafinesque, C. S. Primitive Origin of the English Language. American Antiquities and Discoveries in the West, by Josiah Priest, second edition revised, pp. 325-332, Albany, 1833.

See numbers $838,848,855,880,892$, and 929.

828 R. [AFINESQUE], C. S. [Review of the] ancient chronology of the Onguys or Iroquois Indians. American Antiquities and Discoveries in the West, by Josiah Priest, second edition revised, pp. 346-348, Albany, 1833.

See numbers 839, 849, 855a, 881, 893, and 930.

829 RAFinesQue, C. S. Evidence that a nation of Africans, the descendants of Ham, now inhabit a district of S. America. American Antiquities and Discoveries in the West, by Josiah Priest, second edition revised, pp. 349-352, Albany, 1833.

See numbers 840 and 850 .

830 RaFinesque, C. S. American Languages - Wahtani or Mandan. American Antiquities and Discoveries in the West, by Josiah Priest, second edition revised, pp. 393-395, Albany, 1833.

See number 841 .

831 RAFINESque, C. S. Languages of Oregon - Chopunish and Chinuc. American Antiquities and Discoveries in the West, by Josiah Priest, second edition revised, pp. 395-397, Albany, 1833.

See number 842.

832 Rafinesque, C. S. Letter to Mr. Champollion, on the Graphic Systems of America, and the Glyphs of Otolum of Palenque, in Central America. - Elements of the Glyphs. American Antiquities and Discoveries in the West, by Josiah Priest, third edition revised, pp. 118-124, Albany, 1833.

See numbers 821, 844, 852, 877, 889, 926, 931, and 932.

833 [RAFINESQUE, C. S.] Ruins of the cities of Otolum, discovered in America, of Peruvian origin. American Antiquities and Discoveries in the West, by Josiah Priest, third edition revised, p. 241, Albany, 1833.

Extract from a letter in the body of a paper with the above title and treating of the same subject matter.

See numbers $822,845,853,878,890$, and 927 . 
334 RAFinesque, C. S. Ancient languages of the first inhabitants of America. First letter to Mr. Champollion, on the Graphic Systems of America, and the Glyphs of Otolum or Palenque, in Central America. American Antiquities and Discoveries in the West, by Josiah Priest, third edition revised, pp. 304-309, Albany, 1833.

See numbers 823 and 846 .

835 RaFinesque, C. S. Tabular View of the American Generic Languages and Original Nations, by the same author. American Antiquities and Discoveries in the West, by Josiah Priest, third edition revised, pp. 309-312, Albany, 1833.

See number 824 .

836 [RAFinesque, C. S.] The Atlantic Nations of America. American Antiquities and Discoveries in the West, by Josiah Priest, third edition revised, pp. 312-316, Albany, 1833.

See numbers 825, 847, 854, 879, 891, and 928.

837 RAFINESQUE, C. S. Further accounts of colonies from Europe settled in America. On the Zapotecas, and other tribes of the state of Oaxaca. American Antiquities and Discoveries in the West, by Josiah Priest, third edition revised, pp. 316-325, Albany, 1833.

See number 826 .

838 RAFINESQUe, C. S. Primitive Origin of the English Language. American Antiquities and Discoveries in the West, by Josiah Priest, third edition revised, pp. 325-332, Albany, 1833.

See numbers $827,848,855,880,892$, and 929.

839 RAFINESQUE, C. S. [Review of the] ancient chronology of the Onguys or Iroquois Indians, by David Cusick. American Antiquities and Discoveries in the West, by Josiah Priest, third edition revised, pp. 346-348, Albany, 1833.

See numbers 828, 849, 855a, 881, 893, and 930.

840 RAFinesque, C. S. Evidence that a nation of Africans, the descendants of Ham, now inhabit a district of S. America. American Antiquities and Discoveries in the West, by Josiah Priest, third edition revised, pp. 349-352, Albany, 1833.

See numbers 829 and 850 . 
841 Rafinesque, C. S. American languages - Wahtani or Mandan. American Antiquities and Discoveries in the West, by Josiah Priest, third edition revised, pp. 393-395, Albany, 1833.

See number 830 .

842 RAFINeSQUE, C. S. Languages of Oregon - Chopunish and Chinuc. American Antiquities and Discoveries in the West, by Josiah Priest, third edition revised, pp. 395-397, Albany, 1833.

See number 831.

843 RAFINESQue, C. S.: / Le pulmiste / ou | introduction a l'art de guérir | et de prévenir | la consomption | ou | la phthisie chronique; | (traduit de l'anglais) | par M. le Dr C.-S. Rafinesque, | professeur d'histoire naturelle et de botanique | médicale a Philadelphie, | auteur du manuel de botanique médicale des EtatsUnis, | de l'analyse de la nature, etc., etc. | Membre des Sociétés médicales de Cincinnati, de Lexington et de Phi- | ladelphie, du Lycée de New-York, de l'Académie des Sciences | naturelles de Philadelphie, de la Sociétě des Antiquitiés américaines | de Worcester et de Neschville, de 1'Institute de Kentucki et de plu- I sieurs Sociétés savantes de l'Europe, à Paris, Bruxelles, Vienne, | Bonn, Florence, Naples, etc. | La consomption n'est pas une maladie incurable; mais | les remèdes à y appliquer doivent principalement être | portés au poumon par la respiration ou l'inhalation. | (Le Pulmiste, n. 110.) $|-|$ prix: 4 fr. et 4 fr. 50 c. franc de port. $|-|$ Paris. | Imprimerie de Dezauche, | Faub. Montmartre, No. 11. $|-| 1833$.

Paper, octavo in size and fold, pp. [i-v], vi-ix, [x-xi], xii, [xiii], xiv, [xx, 1], 2-83, [84-85], 86-98, [99], 100-123, [124], plate facing page 98 .

The above is the cover title, the inner title differs by omitting the fifth line of print from the close as well as the "cut-off" rule above the fifth line. Also the word "Kentucki" in the seventeenth line is spelled "Kentucky" on the inner title.

Copies of this volume are in the Library of the Office of the SurgeonGeneral and the Library of the Arnold Arboretum.

This is the French translation of a previous English publication.

See number 555 .

844 RAFINESQUE, C. S. Letter to Mr. Champollion, on the Graphic Systems of America, and the Glyphs of Otolum, or Palenque, in Central America. - Elements of the Glyphs. American 
Antiquities and Discoveries in the West, by Josiah Priest, fourth edition, pp. 118-124, Albany, 1834.

See numbers 821, 832, 852, 877, 889, 926, 931, and 932.

845 [RAFINesque, C. S.] Ruins of the city of Otolum, discovered in North America. American Antiquities and Discoveries in the West, by Josiah Priest, fourth edition, p. 240, Albany, 1834.

See numbers $822,833,853,878,890$, and 927.

846 Rafinesque, C. S. Ancient Languages of the first Inhabitants of America. First Letter to Mr. Champollion, on the Graphic Systems of America, and the Glyphs of Otolum or Palenque, in Central America. American Antiquities and Discoveries in the West, by Josiah Priest, fourth edition, pp. 309-313, Albany, 1834.

See numbers 823 and 834 .

847 [Rafinesque, C. S.] The Atlantic Nations of America. American Antiquities and Discoveries in the West, by Josiah Priest, fourth edition, pp. 313-316, Albany, 1834.

See numbers 825, 836, 854, 879, 891 and 928.

848 Rafinesque, C. S. Primitive Origin of the English Language. American Antiquities and Discoveries in the West, by Josiah Priest, fourth edition, pp. 316-323, Albany, 1834.

See numbers $827,838,855,880,892$, and 929.

849 Rafinesque, C. S. [Review of the] Ancient Chronology of the Onguys or Iroquois Indians, by David Cusick. American Antiquities and Discoveries in the West, by Josiah Priest, fourth edition, pp. 336-338, Albany, 1834.

See numbers 828, 839, 855a, 881, 893 and 930.

850 Rafinesque, C. S. Evidence that a Nation of Africans, the Descendants of Ham, now inhabit a District of South America. American Antiquities and Discoveries in the West, by Josiah Priest, fourth edition, pp. 340-342, Albany, 1834.

See numbers 829 and 840 .

851 1834. Bulletin No. 1. | of the | historical and natural | sciences. | By Prof. C. S. Rafinesque. | | Philadelphia, May, 1834. | One Dollar for 12 Numbers. | - |

Pamphlet, $16 \mathrm{mo}$ in size, quarto in fold, pp. 1-8. The text follows the title. 
A copy of this bulletin is in the Library of the New York Botanical Garden.

Of this series of bulletins the writer has seen only numbers $1,3,7$, and 9.

See numbers 860,886 , and 895 .

The contents are:

851a The littoral Atlantic Islands of North America, pp. 1-4.

851b Ancient names of the principal cities of North America, pp. 4-5.

851c Otolum, near Palenque, pp. 5-6.

851d First catalogue of rare and valuable scientific works, books and manuscripts, maps and drawings, natural objects, \&c., for sale by Prof. C. S. Rafinesque, of Philadelphia, pp. 6-8.

This bulletin was to take the place of the Atlantic Journal in a reduced form. Twelve numbers were to form a volume.

851e Ancient geography of America, pp. 24, illustrated, maps, folio, Philadelphia, 1834.

This has not been seen by the writer. A copy is in the Library of the University of Pennsylvania.

851f Extrait d'une brochure .... intituler Ancient history or annals of Kentucky. In Dupais, G. - Antiquites Mexicaines, vol. 2, part 2, p. 213, 1834.

Not seen by the writer. The title furnished by the Library of the University of Pennsylvania. Rafinesque in his Life of Travels, p. 74, speaks of a French translation, presumably the above title.

See numbers 466 and 467.

852 RAFinesque, C. S. Letter to Mr. Champollion, on the Graphic Systems of America, and the Glyphs of Otolum or Palenque, in Central America. - Elements of the Glyphs. American Antiquities and Discoveries in the West, by Josiah Priest, fifth edition, pp. 123-129, Albany, 1835.

See numbers 821, 832, 844, 877, 889, 926, 931, and 932.

853 [RAFINESQUE, C. S.] Ruins of the City of Otolum, discovered in North America. American Antiquities and Discoveries in the West, by Josiah Priest, fifth edition, p. 246, Albany, 1835.

See numbers $822,832,845,878,890$, and 927.

854 [Rafinesque, C. S.] The Atlantic Nations of America. American Antiquities and Discoveries in the West, by Josiah Priest, fifth edition, pp. 213-315 [313-315], Albany, 1835.

See numbers $825,836,847,879,891$, and 928. 
855 Rafinesque, C. S. Primitive Origin of the English Language. American Antiquities and Discoveries in the West, by Josiah Priest, fifth edition, pp. 315-322, Albany, 1835.

See numbers 827, 838, 848, 880, 892, and 929.

855a Rafinesque, C. S. [Revieze of the] Ancient Chronology" of the Onguys or Iroquois Indians by David Cusick. American Antiquities and Discoveries in the West, by Josiah Priest, fifth edition, pp. 335-336, Albany, 1835.

See numbers 828, 839, 849, 881, 893, and 930.

856 [RAFInESQUE, C. S.] : | Statements | respecting the Divitial Institution of North America, | and | six-per-cent savings-bank. $|=|$ established in the city of Philadelphia. $\mid-1$ Second Edition. | 1

Pamphlet, octavo in size, folio in fold, pp. [1], 2-4. The text follows the title. Part of page 2 and pages 3 and 4 are in two columns to the page. On page 2 occurs: "C. S. Rafinesque, Prof. of His. and Nat. Sciences, and First Founder of this Institution. Philadelphia, 1835." The sixth line of the title is in reversed Italics.

The copy examined is in the Library of Congress.

The writer has not been able to locate a copy of the first edition.

857 Rafinesque, C. S.: | Outlines | of a | general history of America, | from the earliest time to the actual period, | based upon and illustrated by $\mid 1$. The Physical State and Revolutions of this Continent - 2. The Physical and Moral State of the American | Nations - 3. Their Monuments, Languages, Annals, Traditions, Records, Documents, \&c. | including | the ancient and modern history, chronology, geography, and ethnography of the / continent and islands. $|=|$ by $\mid$ Prof. C. S. Rafinesque, A. M. Ph. D. | Member of the American Antiquarian Society, the I. Societies of Vienna and Bonn, and several other learned Societies in Paris, Naples, New York, Philadelphia, Lexington, Cincinnati, Nashville, \&c. $|=|$ in two vols. 8vo. with five maps and twenty plates. | price five dollars. Subscriptions received by the author, Carey \& Lea, \&c. 1

Leaflet, octavo in size, pp. [1-2 blank]. The text follows the title. This is a prospectus only of the proposed work and was issued in about 1836.

The copy examined is in the Library of the New York Botanical Garden.

See number 940. 
858 RAFinesque, C. S.: | Number 1.-spring of $1836 .=\mid$ the | American | nations; | or, | outlines of their | general history. $\mid$ - $\mid$ by Prof. C. S. Rafinesque, | member of many learned societies in $\mid$ America and Europe, author of $\mid$ many works, etc. $|-|$ number first, $\mid$ Generalities and Annals. $|-|$ Philadelphia, | 1836: | published quarterly, | by C. S. Rafinesque, | no. 110 north tenth street, | at five dollars for six numbers. | sold by the principal booksellers; | This Volume for One Dollar, or Six Copies | for Five Dollars.

Paper, octavo or $12 \mathrm{mo}$ in size, 6mo in fold: pp. [i-iv], 1-260. The above is the title on the cover of the paper bound copies. There are two inner titles.

The first inner title reads:

Number 1. spring 1836. $|=|$ the | American nations; | or, | Outlines of A National History; | of the | ancient and modern nations | of $\mid$ North and South America. | - I Of this wide Western Hemisphere, | Let us retrace the history; | Of all the Nations dwelling here, | Let us recall the memory. | _ I first number, or volume: | generalities and annals. $|\longrightarrow|$ by Prof. C. S. Rafinesque, | $-\mid$ Philadelphia, | published by C. S. Rafinesque, | no. 110 north tenth street, | sold by the principal booksellers, | and in London by O. Rich, | in Paris by Meilhac \& Baillere. $|-| 1836 \mid$

The second inner title reads:

The | American nations; | or, | outlines of their | general history, | ancient and modern: | including the whole history of the earth | and mankind in the western hemisphere; | the philosophy of American history; | the annals, traditions, civilization, | languages, \&c., of all the Ameri- | can nations, tribes, empires, I and states. | With Maps, Plates, Views, and Plans of Monuments, | Tables, Notes, and illustrations. | - I by C. S. Rafinesque: | Professor of Historical and Natural Sciences, | Member of many Learned Societies in Paris, Bor- | deaux, Bruxels, Bonn, Vienna, Zurich, Naples, \&c, I in Europe-CPhiladelphia, New York. Cincinnati, | Lexington, Nashville, \&c., in America.-The Ameri- | can Antiquarian Society, \&c. $\mid \longrightarrow$ | | first volume. $|-|$ "All we have hitherto learnt respecting the ancient state of the I "Natives of the New Continent is nothing in comparison to the $\mid$ "light that will be one day thrown on this subject, if we succeed in | "bringing together the materials now scattered over both worlds, | "that have survived the ages of ignorance and barbarism."-Hum- | boldt. | — | Philadelphia: | C. S. Rafinesque, 100 north tenth st. | printed by F. Turner, 367 market st. | 1836 |

See Plate XXI. 


\section{THE}

\section{AMERICAN NATIONS;}

OR,

\section{OUTLINES OF THEIR \\ GENERAL HISTORY,}

\section{ANCIENT AND MODERN:}

INCLUDING THE WHOLE HISTORY OF THE EARTH

AND MANKIND IN THE WFSIERN HEMISPHERE;

THE PHILOSOPHY UF AMERICAAN HISTORY;

THE ANNALS, TRADITIONS, CIVILIZATION,

LANGUAGES, \&c., OF ALL IHF: AMERI-

CAN NATIONS, TRIBES, EMPIRES,

AND STATES.

With Maps, Plates, Vi, ws, and Plans of Monuments, Tables, Notes, and Illustrations.

\section{BY.C. S. RAFINESQUE:}

Professor of Historical and Natural Sciences, Member of many Learned Societies in Paris, Bordeaux, Bruxels. Bunn, Vienua, Zurich, Naples, \&o, in Europe.-Philadelphia, New York. Cincinnati, Lexington, Nashville, dc., in America.-The American Antiquarian Society, \&c.

\section{FIRST VOLUIIE.}

"All we have hitherto learnt respecting the ancient state of the "Natives of the $\mathrm{N}_{\mathrm{c}} \mathrm{w}$ Cortinent is nothing in comparison to the "light that will be one day thrown on this subjeet, if we succeed in "bringing together the materials now scattered over both worlds, "that have survived the ages of ignorance and barbarism." - Hume boldt.

\section{PHILADELPHIA:}

C. S. RAFINESQUE, 110 NORTH TENTH ST. PRINTED BY F. TURNER, 367 MAREET ST,

\section{6}

No. 858. The second inner title to the first volume of Rafinesque's "American Nations" 
859 Rafinesoue, C. S.: | Number 2.- -summer of 1836. $\mid=1$ the | American | nations; | or, | outlines of their | general history. $|-|$ By Prof. C. S. Rafinesque, | member of many learned societies in | America and Europe, author of | many works, etc. $|-|$ number second, | Origin and Researches. | $\mid$ Philadelphia, | 1836: | published quarterly, | By C. S. Rafinesque, | No. 110 north tenth street, | at five dollars for six numbers. | sold by the principal booksellers; | This Volume for One Dollar and Fifty cents | or five dollars for five copies.

Paper, octavo or $12 \mathrm{mo}$ in size, $6 \mathrm{mo}$ in fold, pp. [1-4], 5-292. The above is the title on the cover of the paper bound copies. There are two inner titles.

The first inner title reads:

Number 2. - summer of $1836 .|=|$ the American | nations; | or, | Outlines of a National History; $\mid$ of the $\mid$ ancient and modern nations $\mid$ of $\mid$ North and South America. | $\mid$ Of this wide Western Hemisphere, | Let us retrace the history; | Of all the Nations dwelling here, | Let us recall the memory. $\mid \longrightarrow$ | second number, or volume: | origin and researches. $|-|$ By Prof. C. S. Rafinesque. $|-|$ Philadelphia: | published by C. S. Rafinesque, | no. 110 north tenth street, | sold by the principal booksellers, | and in London, by O. Rich, | in Paris, by Meilhac \& Baillere. $|-| 1836 \mid$

The second inner title reads:

The American | Nations; | or, | outlines of their | general history, | ancient and modern: | including the whole history of the earth $\mid$ and mankind in the western hemisphere; | the philosophy of American history; | the annals, traditions, civilizations, | languages, \&c. of all Ameri- I can nations, tribes, empires, I and states. I With Maps, Plates, Views, and Plans of Monuments, | Tables, Notes, and Illustrations. | | | By C. S. Rafinesque: | Professor of Historical and Natural Sciences, Mem- $\mid$ ber of many Learned Societies in Paris, Bordeaux, | Bruxels, Bonn, Vienna, Zurich, Naples, \&c. in Europe. Philadelphia, New York, Cincinnati, Nashville, \&c. I in America. - The American Antiquarian Society, \&c. $|-|$ second volume. $\mid-1$ "All we have hitherto learnt respecting the ancient state of the | "Natives of the New Continent is nothing in comparison to the | "light that will be one day thrown on this subject, if we succeed in I "bringing together the materials now scattered over both worlds, | "that have survived the ages of ignorance and barbarism." - I Humboldt's Researches. I - Philadelphia: | C. S. Rafinesque, 110 north tenth st. | F. Turner, printer. $|-| 1836 \mid$

The dedication of his memorable work "The American Nations" is dated 1833, yet the two small volumes of less than three hundred pages 
were not issued until 1836. Those who will give this work patient and thoughtful consideration will be surprised at the mass of information it contains, the immense learning involved in its production, and the ability with which theories are advanced and supported-yet it is probably a mere synopsis of his vast collections relating to the subjects discussedin other words he was compelled to condense his material in proportion to his ability to pay the printer. The student of history in his examination of this work, must ever regret the circumstances that enforced the brevity with which the subjects requiring elaboration are treated-ChasePotter's American Monthly, 6:99.

Copies of The American Nations are in the Library of the Wagner Free Institute of Science; Yale University Library; Boston Public Library; The New York Library (Vol. 1 only); Library of Harvard University; Library of the Arnold Arboretum (Vol. 1 only) ; Library of Boston Athenaeum; Library of the State Historical Society of Wisconsin; Library of Congress; Library of the Smithsonian Institution; The Newberry Library (The Ayer Collection); Pennsylvania State Library; Library of the British Museum; Library of the State Historical Society of Pennsylvania; and the Fitzpatrick Collection.

860 RafinesQue, C. S.: | 1836. Bulletin Nr. 3. | of the | historical and natural | sciences. | By Prof. C. S. Rafinesque. $|-|$ Philadelphia, May, 1836. $\mid-1$

Pamphlet, $16 \mathrm{mo}$ in size, quarto in fold, pp. [17], 18-24. The text follows. The above is the subtitle of an advertising circular distributed by Rafinesque. Statements are given concerning his work and his publications.

Copies of this bulletin are in the Library of Congress; the Library of the New York Botanical Garden; and the Boston Public Library, bound in the back part of the volume containing Rafinesque's American Nations.

See numbers 851,886 , and 895 .

861 [RAFInESQUe, C. S.] : The world, | or | instability. | a poem. | in twenty parts, | with notes and illustrations. | - 1

If Solomon did say, that nothing new |

Under the sun was seen, 'tis not quite true: !

Since we contend, that ev'ry hour and day

Brings novelties, with changes' due array. |

Whatever had a birth must change sustain, |

Unsteady ever be; but not in vain: |

Enjoying life must die to live again,

In afterlives perfection to attain.

| - Philadelphia and London: | published by J. Dobson, Chesnut street. | and the principal booksellers in Philadelphia. | 
price one dollar and fifty cents. $|-|$ in London — by O. Rich, | price seven shillings. | 1836.|

Boards, quarto in fold, octavo or 12mo in size, pp. [1-5], 6-248. Pages 217-243 contain a variety of notes, scientific and literary, intended to eludicate the text.

See Plate XXII.

The cover title, reads:

The world, | or | instability, | $\mid$ | a poem. | with notes and illustrations. $\left|\_\right|$Philadelphia: | 1836. | price one dollar and fifty cents. |

The binder's label reads:

Rafinesque. $|\longrightarrow|$ the $\mid$ world, $\mid$ a $\mid$ poem. $\mid$

See number 862.

Copies of this book of poems are in the Library of the State Historical Society of Wisconsin; Library of Congress; and Library of the New York Botanical Garden.

862 Rafinesque, C. S.: | The world, | or | instability, | a poem, | with notes and illustrations. | - by Constantine Jobson. $|-|$ second edition. $\mid-1$

If Solomon did say, that nothing new |

Under the sun was seen, 'tis not quite true:|

Since we contend that ev'ry hour and day |

Brings novelties, with changes due array. $\mid-1$

Whatever had a birth must change sustain,

Unsteady ever be; but not in vain: |

Enjoying life must die to live again, |

In after lives perfection to attain.

$\mid$ - Philadelphia \& London | C. S. Rafinesque publisher of American works, | no. 110 north tenth street, Philadelphia. | sold by the principal booksellers. | price one dollar fifty cents. | in London, by O. Rich, American bookseller. | price seven shillings. 1836. |

See Plate XXIII.

Octavo or $12 \mathrm{mo}$ in size, quarto in fold, pp. [1-5], 6-248.

A scientific poem intended to teach the theory of evolution. Pages 217-243 contain a variety of notes, scientific and literary, intended to eludicate the text.

The only copy of this edition known to the writer is in the Fitzpatrick Collection.

See number 861 . 


\title{
TIIIS WOBAD
}

\author{
or
}

I N S I A I L L I T Y

\section{A PEM.}

IN TWENY PARTS,

WITH NOTES ANI TLI.USTRATIONS.

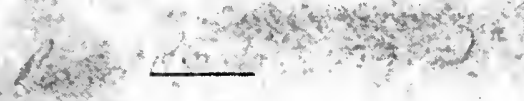

If Solomon did say, that mothiner new,

Uncler the sun was seen, 'tis not quite true:

Since we contend, that every hour and way

Briris novelties, with changes' due array.

Whatever had a birth must change sistain,

Unstealy ever be; but not in vain:

Enjoring life inust die to live again,

In alterlives perfection to attiin.

PHILADELPHI. . IND HONDON:

PUBLISHED BY J. DGBSON,-CHESNUT STREET.

AND THE PRTCCIPAL WOOKSEJ.LEIS IX PHILADELPHA.

PRICE UNH DOL.AR ANL FITTX CEXTS.

IN LONDO $\overline{\mathrm{N}-\mathrm{BY}}$ O. RICII, PRICE SEVES SILLLNGS.

1836.

No. 861. Title to the first erlition of Rafinesque's "The World or Instability" 



\section{THE WORLD.}

\section{OR \\ I N S T T A B I L I T Y}

A POEM,

WITH NOTES AND ILLUSTRATIONS.

BY CONSTANTINE JOBSON.

\section{SECOND EDITION.}

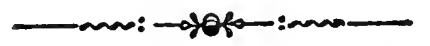

If Solomon did say, that nothing rew Under the sun was seen, 'tis not quite true:

Since we contend that ev'ry hour and day

Brings novelties, with charges due array.

Whatever bad a birth must change sustain, Unsteady ever be; but not in vain : Enjoying life must die to live again, In after lives perfection to attain.

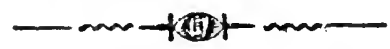

\section{PHILADELPHIA \& LONDON}

C. S. RAFINESQUE PUBLISHER OF AMERICAN WORKS NO. 110 NORTH TENTH STREET, PHILADELPHLA. SOLD BY THE PRINCIPAL BOOKSELLERS. PRICE ONE DOLLAR FIFTY CENTS.

IN LONDON, BY O. RICH, AMERICAN BOOKSELLER. PRICE SEVEN SIILLINGS.

\section{4.}

No. 862. Title to the second edition of Rafinesque's "The World or Instability" 
863 RAFINESQUE, C. S.: | A | life of travels $\mid$ and | researches | in North America and South Europe, | or | outlines | of | The Life, Travels and Researches | of | C. S. Rafinesque, A. M. Ph. D. | Professor of historical and natural scien- | ces, member of many learned Societies in | Europe and America, author of many | works, \&c. | containing | His travels in North America and the South of Europe; the Atlantic | Ocean, Mediterranean, Sicily, Azores, \&c. | from 1802 to 1835 - with sketches of his | scientific and historical researches, \&c. $|-|$ Un voyageur dés le berceau, $\mid$ Je le serais jusqu' au tombean .... | - Philadelphia | printed for the author, | by F. Turner, no. 367, market street. | 1836. | price seventy-five cents.

Paper, $12 \mathrm{mo}$ in size, $6 \mathrm{mo}$ in fold, pp. [1-4], 5-148.

See Plate XXIV.

The title on the cover reads:

A | life of travels | and | researches | in North America | and the south of Europe, | From 1805 till 1835. | $\mid$ Philadelphia | 1836. | price seventy-five cents. 1

See Plate XXV.

Copies of this volume are in the Library of the Historical Society of Pennsylvania; the Library of New York Botanical Garden; Library of Congress; The John Crerar Library; Library of the Gray Herbarium; Yale University Library; Boston Public Library; Library of Harvard University; Library of the Harvard Museum of Comparative Zoölogy; Library of the Arnold Arboretum; Library of the Boston Athenaeum; Library of the State Historical Society of Wisconsin; Library of the Smithsonian Institution; Chicago Public Library; Library of the University of Pennsylvania; Library of the British Museum; and the Fitzpatrick Collection.

2864 Rafinesque, C. S.: | First part. | introd. lexicon, \&c. $1=\mid$ new flora $\mid$ and botany $\mid$ of $\mid$ North America. | being a supplemental flora, | To the various Floras and Botanical Works of Michaux, | Muhlenberg, Pursh, Nuttall, Elliot, Torrey, Beck, Ea- | ton, Bigelow, Barton, Robin, Hooker, Riddell, Darling- | ton, Schweinitz, Gibbs, \&c. | Besides the general works of Linneus, Wildenow, | Vahl, Vitman, Persoon, Lamark, Decandole, Sprengel, | Jussieu, Adanson, Necker, Lindley, \&c. Containing | nearly 500 additional or revised New Genera, and 1500 | additional or corrected New Species, illustrated by $\mid$ figures in Autikon Botanikon. | by C. S. Rafinesque, A. M. - Ph. D. | Prof. of 



\section{$\mathbf{A}$ \\ LIFE OF TRAVELS \\ $\boldsymbol{A} \cdot \boldsymbol{W}$}

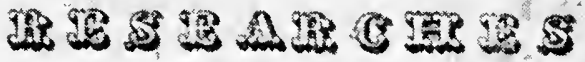

IN NORTII AMERICA AND SOUTII EUROPE; OR

\section{OUTIINES}

or

The Life, Travels and Researches

C.S.RAFINESQUE, A M. PH. D.

Professor of historical and natural scien ces, member of nany learned Societies in: Europe and America, author of many works, \& .

\section{CONTAINING}

His travels in NORTH AMERICA and the SOUTH of EUROPE; the Atlantic Ocean, Medichanean, Sicily, Azores, \&C. from 1802 to 1835 - with sketches of his scientific and historical researches, \&.

Un voyageur dés le berccau,

Je le serais jusqu' au tombean....

\section{PIIILA DELPIIA}

PRINTED FOT THE AUTTOR,

Y 7 . TURNER, NO, 367, MARKET STREET.

1836 .

PRICE SEVENTX-FIVE CENTS.

No. 863. The inner title to Rafinesque "s "Life of Travels" 


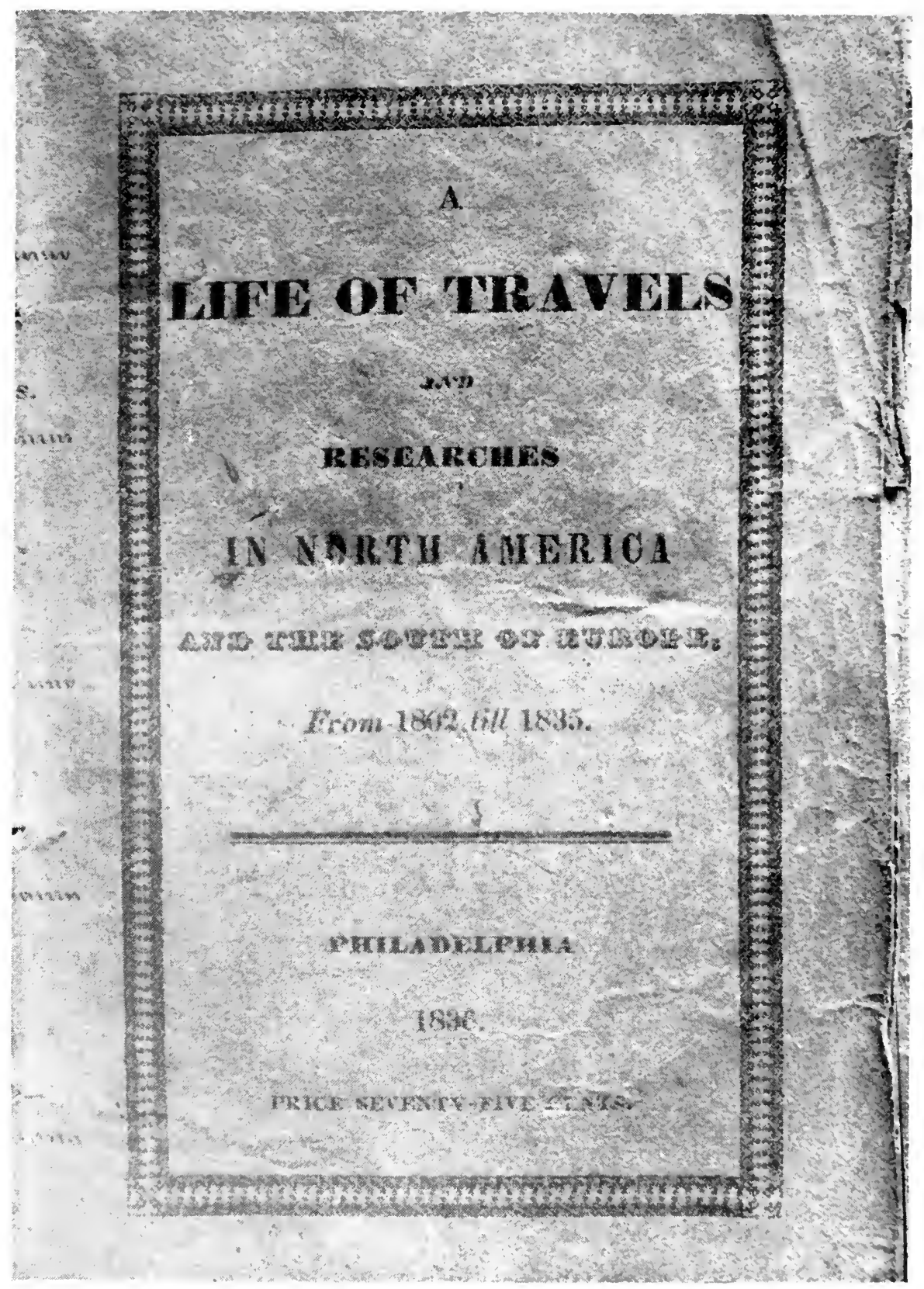

No. 863. The cover title to Ratinesque's "Life of Travels" 

Botany, the historical and natural sciences - Member of many learned Societies in Paris, Vienna, | Bonn, Bruxelles, Bordeaux, Zurich, Naples, \&c. and | in Philadelphia, New York, Cincinnati, Lexington, \&c. $|-|$ The Floral wealth in this wide land concealed, | Will be at last by learned care revealed. | - I Philadelphia: | printed for the author and publisher. | 1836. |

Paper, octavo in size, quarto in fold, pp. [1-2], 3-100.

The cover title reads:

New flora | of | North America, | by | Prof. Rafinesque. | 1 first part. | Introduction, Lexicon, Monographs. $|-|$ Philadelphia $\mid$ | 1836. |

Copies are in the Library of the Gray Herbarium; Chicago Public Library; Yale University Library; Library of the Arnold Arboretum; Library of the State Historical Society of Wisconsin; Library of the Smithsonian Institution; Library of Congress; Library of the New York Botanical Garden; Library of the Historical Society of Pennsylvania; Library of the British Museum; and the Library of the Field Museum of Natural History.

865 RaFinesque, C. S.: | Second part. | neophyton | new flora $\mid$ and botany $\mid$ of $\mid$ North America. | being a suplemental flora, $\mid$ To the various Floras and Botanical Works $\mid$ of Michaux, Muhlenberg, Pursh, Nuttal, El- | liot, Torrey, Beck, Eaton. Bigelow, Barton, | Robin, Hooker, Riddell, Darlington, Schweinitz | Gibbs, \&c. | Besides the great works of Linneus, Wilde- | now, Vahl, Vitman, Persoon, Lamark, Decan- | dole, Sprengel, Jussieu, Adanson, Necker, | Lindley, \&c. Containing nearly 500 additional | or revised New Genera, and 1500 additional | or corrected New Species, illustrated by figures | in Autikon Botanikon. | by C. S. Rafinesque, A. M. - Ph. D. | Prof. of Botany, the historical and natural sciences - $\mid$ Member of many learned Societies of Paris, Vienna. | Bonn, Bruxelles, Bordeau, Zurich, Naples, \&c. and | in Philadelphia, New York, Cincinati, Lexington, \&c. | - The Floral wealth in this wide land concealed, | Will be at last by learned care revealed. | | | Philadelphia: | printed for the author and publisher. $|1836$.

Paper, octavo in size, quarto in fold, pp. [1-2], 3-96.

The cover title reads :

New flora | of | North America, | by | Prof. Rafinesque. | - | second part. $\mid$ Neophyton. |- $\mid$ Philadelphia $|-| 1836 . \mid$

Copies are in the Library of the Gray Herbarium; Library of the 
Arnold Arboretum; Library of the New York Botanical Garden; Yale University Library; Library of the Historical Society of Pennsylvania; and the Library of the British Museum.

866 RaFinesque, C. S.: | Third part. | new sylva. | new flora $\mid$ and botany | of | North America. | being a supplemental flora, | To the various Floras and Botanical Works | of Michaux, Muhlenberg, Pursh, Nuttal, El- | liot, 'Torrey, Beck, Eaton, Bigelow, Barton, | Robin, Hooker, Riddell, Darlington, Schweinitz | Gibbs, \&c. | Besides the great works of Linneus, Wilde- | now, Vahl, Vitman, Persoon, Lamark, Decan- | dole, Sprengel, Jussieu, Adanson, Necker, | Lindley, \&c. Containing nearly 500 additional | or revised New Genera, and 1500 additional | or corrected New Species, illustrated by figures | in Autikon Botanikon. | by C. S. Rafinesque, A. M. - Ph. D. | Prof. of Botany, the historical and natural sciences - $\mid$ Member of many learned Societies of Paris, Vienna. | Bonn, Bruxelles, Bordeaux, Zurich, Naples, \&c. and | in Philadelphia, New York, Cincinati, Lexington, \&c. 1 - The Floral wealth in this wide land concealed, | Will be at last by learned care revealed. | $\mid$ Philadelphia: | printed for the author and publisher. | $1836 . \mid$

Paper, octavo in size, quarto in fold, pp. [1-3], 4-96.

The cover title reads:

New flora | of | North America. | by | Prof. Rafinesque. | - | third part. $\mid$ New Sylva. $|-|$ Philadelphia $|-| 1836 . \mid$

Copies are in the Library of the Gray Herbarium; Library of the Harvard Museum of Comparative Zoölogy; Chicago Public Library; Library of the Arnold Arboretum; Library of the State Historical Society of Wisconsin; Library of the New York Botanical Garden; Library of Congress; Library of the Smithsonian Institution; Yale University Library; Library of the U. S. Department of Agriculture; Library of the Historical Society of Pennsylvania; and the Library of the British Museum.

867 RAFINESQUE, C. S.: | Fourth part. | neobotanon. $|=|$ new flora / and botany / of | North America. | being a supplemental flora, | To the various Floras and Botanical Works / of Michaux, Muhlenberg, Pursh, Nuttal, El- | liot, Torrey, Beck, Eaton, Bigelow, Barton, | Robin, Hooker, Riddell, Darlington, Schweinitz | Gibbs, \&c. | Besides the great works of Linneus, Wilde- | now, Vahl, Vitman, Persoon, Lamark, Decan- | dole, Sprengel, Jussieu, Adanson, Necker, | Lindley, \&c. containing 
nearly 500 additional | or revised New Genera, and 1500 additional | or corrected New Species, illustrated by figures | in Autikon Botanikon. | by C. S. Rafinesque, A. M. - Ph. D. | Prof. of Botany, the historical and natural sciences - $\mid$ Member of many learned Societies of Paris, Vienna. | Bonn, Bruxelles, Bordeaux, Zurich, Naples, \&c. and | in Philadelphia, New York, Cincinati, Lexington, \&c. $\mid$ - The Floral wealth in this wide land concealed, $\mid$ Will be at last by learned care revealed $|-|$ Philadelphia: | printed for the author and publisher. | 1836. |

Paper, octavo in size, quarto in fold, pp. [1-4], 5-112.

The title above is the one given on page 3 . The title on page one is for the completed work of four parts.

The cover title reads:

New flora | of | North America, | by | Prof. Rafinesque. | - | fourth part. | Neobotanon. | $\mid$ | Philadelphia | - $\mid$ 1836. |

Copies of this work are in the Library of the Gray Herbarium; Library of Harvard Museum of Comparative Zoölogy; Chicago Public Library; Library of the Arnold Arboretum; Library of the Smithsonian Institution; Library of Congress; Library of the New York Botanical Garden; Yale University Library; Library of the British Museum; Library of the U. S. Department of Agriculture; Library of the Historical Society of Pennsylvania; and the Fitzpatrick Collection.

868 RAFINESQUE, C. S.: | New flora | and botany $\mid$ of $\mid$ North America | or | a supplemental flora, | additional to all the botanical works on | North America and the United States. Containing 1000 new or revised Species. | - by C. S. Rafinesque A. M. Ph. D. | Prof. of Botany, the Historical and Natural | Sciences, member of many learned Societies. | $\mid$ in four parts. I I Lexicon and Monographs. | II Neophyton \&c. | III New Sylva \&c. | IV Neobotanon \&c. - with Introductions, | Sketches, Notes, Indexes, \&c. $|-|$ The floral wealth in this wide land concealed | Will be at last by learned care revealed. $|+|$ Philadelphia. | 1836. | Price Five Dollars - \$20 for 5 Copies.

The above is the title to the complete work of four parts, the titles of which are given above.

As to the real dates of issue of the parts of the New Flora see Bibliotheca Rafinesquiana, no. 10.

869 RAFinesque, C. S. : | First part | of the | synoptical flora telluriana, | introduction \& classification, | With new Natural Classes, Orders and fami- | lies: preamble of the $2000 \mathrm{New}$ or 
revised Gen- | era and Species of Trees, Palms, Shrubs, Vines, | Plants, Lilies, Grasses, Ferns, Algas, Fungi \&c. | from North and South America, Polynesia, | Australia, Asia, Europe and Africa, omitted or | mistaken by the authors, that were observed or | ascertained, described or revised, collected or | figured, between 1796 and 1836, | by C. S. Rafinesque, A. M. | Prof. of Botany, historical and natural scien- $\mid$ ces - member of many learned Societies in | Paris, Vienna, Bruxelles, Bonn, Bordeaux, | Zurich, Naples \&c. Philadelphia, New York, | Cincinnati, Lexington, \&c. $|-|$ To observe and compare, to correct or approve |By good names and new facts that convince and improve. | - I Philadelphia: | printed for the author | by H. Probasco, no. 119, north fourth st. | $1836 . \mid$

Paper, octavo in size, quarto in fold, pp. [1-6], 7-101, [102-104].

A second title page facing the above reads:

Floral telluriana | pars prima. $=\mid$ introd. et classific. | ad mantissa synoptica | 2000 | nova genera plantarum | vel nov. ord. et spec. | in orbis tellurianum | Determ. coll. inv. obs. et descr. ad | C. S. Rafinesque, Bot. Prof. \&c. | Ann. 1796 ad 1836 $|=|$ Philadelphia | 1836. |

The subtitle on page [1] reads:

Flora telluriana | pars prima. |

The cover title reads:

Flora | telluriana | $\mid$ by Prof. Rafinesque. $|-|$ first part. $\mid$ $-\mid$ Philadelphia $|-| 1836 . \mid$

Collation: [titles, pp. 1-3; note, p. 4] ; dedication, p. [5] ; notice, p. [6] ; introduction, pp. 7-25; natural classification, pp. 26-27; table of new natural families and their types in 1815, pp. 27-44; natural classes and orders of C. S. Rafinesque, 1815 , pp. $44-57$; the natural classes, rectified 1835 , pp. $58-80$; the fifty rules of generic nomenclature by Linneus and Rafinesque, 1814 ; pp. 81-90; conclusion and natural genera, pp. 90-101; p. [102], blank; table of contents, p. [103]; page [104] blank.

870 RAFinesque, C. S.: | Flora telluriana | pars secunda. $1=\mid$ second part $\mid$ of the | synoptical flora telluriana, | centuria I, II, III, IV. | With new Natural Classes, Orders and fami- | lies: preamble of the $2000 \mathrm{New}$ or revised Ge- | nera and Species of Trees, Palms, Shrubs, Vines, | Plants, Lilies, Grasses, Ferns, Algas, Fungi, \&c. | from North and South America, Polynesia, | Australia, Asia, | Europe and Africa, omitted or $\mid$ mistaken by the authors, that were observed or | ascertained, described or revised, collected or | figured, between 1796 and 1836. | by C. S. Rafi- 
nesque, A. M. | Prof. of Botany, historical and natural sci- | ences - member of many learned Societies in | Paris, Vienna, Bruxelles, Bonn, Bordeaux, | Zurich, Naples, \&c. Philadelphia, New York, | Cincinnati, Lexington, \&c. $|-|$ To observe and compare, to correct or approve | By good names and new facts that convince and improve. | - $\mid$ Philadelphia: | printed for the author $\mid$ by $\mathrm{H}$. Probasco, no. 119 north fourth st. | 1836.

Paper, octavo in size, quarto in fold, pp. [1-3], 4-112.

The cover title reads:

Flora | telluriana | - $\mid$ by Prof. Rafinesque. | $-\mid$ second part. $|-|$ Philadelphia $|-| 1836 . \mid$

Collation: [title page, p. 1 ; note, p. 2]; explanations of some botanical terms, pp. [3] -5 ; some abbreviations used in this work, pp. 6-8; flora telluriana, centuria prima, pp. 9-33; flora telluriana, centunia [centuria] secunda, pp. 33-56; flora telluriana, centuria tertia, pp. 57-80; flora telluriana, centuria quarta, pp. 81-105; index, pp. [106]-112.

871 RAFinesque, C. S.: | Flora telluriana | pars tertia. $1=\mid$ third part $\mid$ of the | synoptical flora telluriana, | centuries V, VI, VII, VIII. | With new Natural Classes, Orders and fami- | lies: containing the $2000 \mathrm{New}$ or revised Ge- | nera and Species of Trees, Palms, Shrubs, Vines, | Plants, Lilies, Grasses, Ferns, Algas, Fungi, \&c. | from North and South America, Polynesia, | Australia, Asia, Europe and Africa, omitted or | mistaken by the authors, that were observed or | ascertained, described or revised, collected or | figured, between 1796 and 1836. | by C. S. Rafinesque, A. M. | Prof. of Botany, historical and natural sci- | ences - member of many learned Societies in | Paris, Vienna, Bruxelles, Bonn, Bordeaux, | Zurich, Naples, \&c. Philadelphia, New York, | Cincinnati, Lexington, \&c. $|-|$ To observe and compare, to correct or approve |By good names and new facts that convince and improve. | - | Philadelphia. | printed for the author | by H. Probasco, no. 119, north fourth st. | 1836. |

Paper, octavo in size, quarto in fold, pp. [1-3], 4-100.

The cover title reads:

Flora | telluriana $|\longrightarrow|$ by Prof. Rafinesque. $|-|$ third part$|-|$ Philadelphia $|-| 1836$.

The collation is: [title page, p. 1; note, p. 2]; preamble to the third part, pp. [3]-9; flora telluriana, centuria v, pp. 9-31; centuria vi, pp. 3250 ; centuria vii, pp. 50-71; centuria viii, pp. 72-95; index, pp. 96-100. 
872 RAFINESQUE, C. S.: | Flora telluriana | pars iv et ult. $=\mid$ fourth and last part | of the | synoptical flora telluriana, | centuries IX, X, XI, XII. | With new Natural Classes, Orders and Fam- | ilies: containing the 2000 new or revised Gen- | era and Species of Trees, Palms, Shrubs, Vines, / Plants, Lilies, Grasses, Ferns, Algas, Fungi, | \&c, from North and South America, Polynesia, | Australia, Asia, Europe and Africa, omitted or | mistaken by the Authors, that were observed or | ascertained, described or revised, collected or | figured, between 1796 and 1836. | by C. S. Rafinesque, A. M. | Prof. of Botany, historical and natural sci- | ences-member of many learned Societies in I Paris, Vienna, Bruxelles, Bonn, Bordeaux, | Zurich, Naples, \&c. Philadelphia, New York, | Cincinnati, Lexington, \&c. $|-|$ To observe and compare, to correct or approve $\mid$ By good names and new facts that convince and improve. $\left|\_\right|$Philadelphia. | printed for the author | By H. Probasco, No. 119, N. Fourth St. | 1836.

Paper, octavo in size, quarto in fold, pp. [1-4], 5-135, [136 blank].

The cover title reads:

Flora | telluriana $|-|$ by Prof. Rafinesque. $|-|$ fourth part. $|\longrightarrow|$ Philadelphia $|\longrightarrow|$ 1836. $\mid$

The collation is: [title page to complete work, p. 1 ; note, p. 2; title to part iv, p. 3]; notice, p. [4]; preamble to the fourth and last part, pp. 5-7 ; flora telluriana, ceturiana $\mathrm{Ix}$ monocot., pp. 8-35; ceturia $\mathrm{x}$ monocot., pp. 36-69; ceturia XI, dicotyles - peripetalic, pp. 69-96; centuria XII, pp. 97-120; additions and corrections, pp. 121-125; index, pp. 126-135; page [136] blank.

On page [4] of part four Rafinesque says: "only 160 copies were printed, which makes it high, as but few copies can be sold in America, where Botanists cannot duly appreciate it, and they must be sent to Europe, to be often exchanged instead of sold."

873 Rafinesque, C. S. : | Flora telluriana | centur. I.-XII. | $=\mid$ mantissa synoptica. $|2000|$ N. Ord.-N. Gen.-N. Sp. $\mid$ plantarum | in orbis tellurianum. | Determ. coll.inv. obs. et. descr. | Ann. 1796-1836. | — Auctore C. S. Rafinesque, Bot. Prof. | - $\mid$ Philadelphia. $|=| 1836$.

The title to the complete work of four parts.

A copy of the complete work is in the Library of the Gray Herbarium; also the Library of Congress; Library of the New York Botanical Garden; Library of the British Museum; Library of the Historical So ciety of Pennsylvania (parts 1, 3, and 4 only) ; Library of the U.S. Depart- 
ment of Agriculture (parts 1 and 2 only); and the Library of the Arnold Arboretum (parts 1 and 2 only).

As to the real dates of issue of the Flora Telluriana see Bibliotheca Rafinesquiana, no. 10.

874 Rafinesque, C. S.: | The universe | and | the stars, | Being an Original theory on the visible |Creation, founded on the laws of Nature, | by Thomas Wright. |= | first American edition, | from the London edition of 1750, | with notes | by C. S. Rafinesque, | Prof. of historical and natural Sciences. $|-|$ One Sun by day, by night ten thousand shine | And light us dcep into the Deity. | Dr. Young. | - | Philadelphia: | 1837. | printed for Charles Wetherill, | By H. Probasco, 119, North Fourth-street, below Callowhill. | and sold by the principal Booksellers. |

Paper, octavo in size, quarto in fold, pp. [i-iv], 1-158, [159-160]

The cover title reads:

The | universe | and the | stars, | or theory of the visible and invisible | creation, | by Thomas Wright. | - | with notes by Prof. Rafinesque. | | first American edition. | Philadelphia: | 1837. |

The portions written by Prof. Rafinesque are: "Preface of the American editor," pp. 4-8; and "Notes by Prof. Rafinesque," pp. 147-158.

Copies of this work are in the Yale University Library; The New York Public Library; Library of the Arnold Arboretum; Library of the State Historical Society of Wisconsin; Library of the Smithsonian Institution; Library of the British Museum; Library of the Historical Society of Pennsylvania; and the Fitzpatrick Collection.

875 Rafinesque, C. S. : | Safe banking, | including | the principles of wealth; | being an enquiry into the principles and | practice of safe and unsafe banks, or / monied institutions in North America, | the defects of the American banking | system and legislation, \&c. | by C. S. Rafinesque, | A. M.-Ph. D. Prof. of Historical and Natural Sciences, | member of 15 learned Societies in America and | Europe, Author of 50 Works.-Founder of the | Divitial Institution of North America, and | many other useful Institutions, \&c. $|-|$ Every Bank liable to risks or losses and to sudden calls | is UNSAFE.-Every Bank liable to neither is SAFE. | - $\mid$ Philadelphia: | 1837. | Printed by order and at the expense of the | divitial institution of North America, | and 6 per cent savings-bank.

Paper, $12 \mathrm{mo}$ in size, 6mo in fold, pp. [1-3, 4-136, [137-138]. 
The cover title reads:

Safe banking | including | the principles | of | wealth. | - I Every Bank liable to risks or losses and | sudden calls is UNSAFE. Every Bank liable to neither is SAFE. | $\mid$ Philadelphia. | 1837. | price fifty cents. 1

See Plate XXVI.

Copies of this volume are in the Library of the New York Botanical Garden; Library of the State Historical Society of Wisconsin; Library of Harvard University; Library of the Arnold Arboretum; Library of the Boston Athenaeum; Library of Congress; Library of the Smithsonian Institution; Library of the University of Pennsylvania; Pennsylvania State Library; Library of the Historical Society of Pennsylvania; and the Fitzpatrick Collection.

876 [RAFineSQue, C. S.] : | Second edition, 1st June, 1837. - Plan | Of the Philadelphia Land Company of | Aurora, | Intending to build a City, and four Towns on | 66,640 Acres of Western Land. Capital | \$96,000 in 1600 Shares of $\$ 60$. Each en- | titling to a Farm of 40 Acres, a City Lot of | one-fourth Acre, and a Town Lot of one Acre. $|-|$ Wealth and Happiness. $\mid$

Pamphlet, octavo in size, quarto in fold, pp. [1], 2-8. Text follows the title. The pamphlet is dated on page 8-"Philadelphia, 15th April 1837," and the signature: "Charles Wetherill, President, 21 Arch st., C. S. Rafinesque, Secretary, at the Office."

A copy of this pamphlet is in the Library of the New York Botanical Garden.

The writer has not been able to find a copy of the first edition.

Concerning this Land Company the writer finds the following which is an extract from the letter of John Plumbe, Jr., dated Du Buque, W. T. [Dubuque, Iowa], Nov. 6, 1837, and published at Dubuque, in the Iowa News for Saturday, November 18, 1837.

"I have written to Prof. Rafinesque. Sec'y of the Philadelphia Land Company, and to the Trustees of the N. Y. Emigrating Society, inviting them to examine the merits of Wisconsin before locating their respective colonies."

877 Rafinesque, C. S. Letter to Mr. Champollion, on the Graphic Systems of America, and the Glyphs of Otolum, or Palenque, in Central America. Elements of the glyphs. American Antiquities and Discoveries in the West, by Josiah Priest, fifth edition, pp. 123-129, Albany, 1837.

See numbers 821, 832, 844, 852, 889, 926, 931, and 932. 


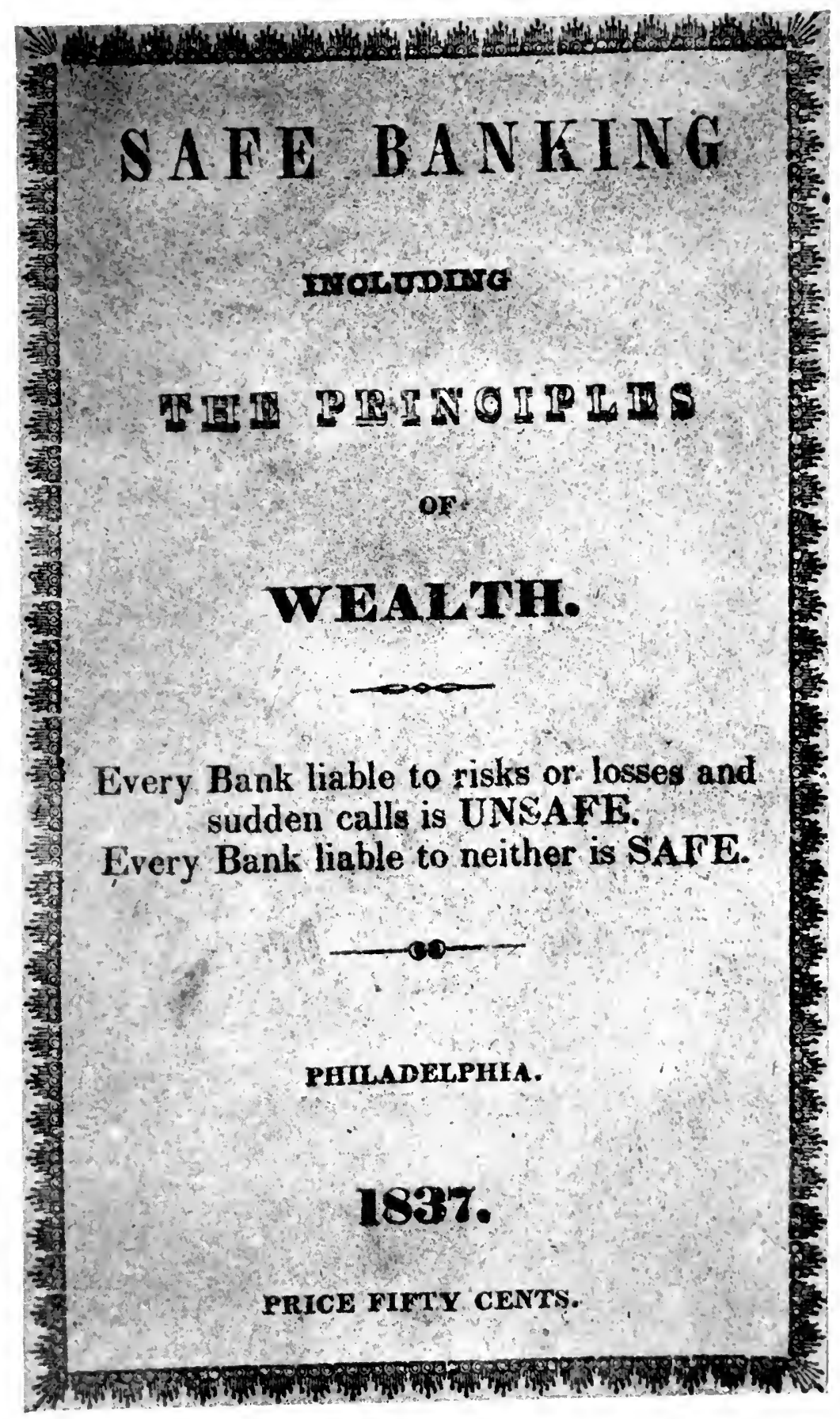

No. 875. Cover title to Kafinesque's treatise on "Safe Banking" 

878 [RAFINESQUE, C. S.] Ruins of the City of Otolum, discovered in North America. American Antiquities and Discoveries in the West, by Josiah Priest, fifth edition, p. 246, Albany, 1837.

Contains an extract from a letter by Rafinesque.

See numbers $822,833,845,853,890$, and 927.

879 [Rafinesque, C. S.] The Atlantic Nations of America. American Antiquities and Discoveries in the West, by Josiah Priest, fifth edition, pp. 213-315 [313-315], Albany, 1837.

See numbers $825,836,847,854,891$, and 928.

880 Rafinesque, C. S. Primitive Origin of the English Language. American Antiquities and Discoveries in the West, by Josiah Priest, fifth edition, pp. 315-322, Albany, 1837.

See numbers 827, 838, 848, 855, 892, and 929.

881 Rafinesque, C. S. [Review of the] Ancient Chronology of the Onguys or Iroquois Indians. American Antiquities and Discoveries in the West, by Josiah Priest, fifth edition, pp. 335-336, Albany, 1837.

See numbers $828,839,849,855 \mathrm{a}, 893$, and 930 .

882 Rafinesque, C. S.: | Genius and spirit | of the | Hebrew Bible. | including the biblic philosophy of | celestial wisdom, religion and theo- | logy, astronomy and realization, | ontology and mythology, chrono- | metry and mathematics. | Being the First Series of Biblic Truths, | Ascertained and Explained by the | true restored names and words in Eng- | lish Letters, of the Religious and Philoso- | phical Conceptions of the OBRI or He- | brew Language relating thereto, that are $\mid$ found in the MKRE or Hebrew Scrip- | tures, with their meanings and deriva- | tions: whereby the real ancient OBRI | knowledge is restored and found to agree | with the highest modern knowledge. | by C. S. Rafinesque. A. M. Ph. D. | Prof. of Historical and Natural Sci- $\mid$ ences, of Languages and comparative | Philology-Member of many learned | Societies in Europe and America-Au- | thor of many WorksFounder of the $\mid$ Central University of Illinois \& $c .|-|$ Philadelphia. | 1838. | Printed for the Eleutherium of Know- ledge, and Central University of Illinois. 1

Paper, octavo or $12 \mathrm{mo}$ in size, $6 \mathrm{mo}$ in fold, pp. [1-4], 5-264. 
The cover title reads:

Bini obri - Hebrew wisdom. $|=|$ genius and spirit $\mid$ of the $\mid$ Hebrew Bible. | By Prof. C. S. Rafinesque. | [cut] | wisdom. | Philadelphia. | 1838. | 1 price one dollar. |

See Plate XXVII.

Copies of this religious work are in the Yale University Library; Boston Public Library; Library of Harvard University; Library of the Arnold Arboretum; Library of the Boston Athenaeum; Library of the State Historical Society of Wisconsin; Library of the Smithsonian Institution; Library of Congress; Pennsylvania State Library; Library of the University of Pennsylvania; The Newberry Library; Library of the British Museum; Library of the Historical Society of Pennsylvania; and the Fitzpatrick Collection.

883 RAFINESQUE, C. S.: | Alsographia | Americana, | Or an American Grove of New or revised | Trees and Shrubs of the Genera Myrica, Caly- | canthus, Salix, Quercus, Fraxinus, Populus, Ti- | lia, Sambucus, Viburnum, Cornus, Juglans, 死s- | culus \&c, with some New Genera, Monographs, | and many new Sp. in 330 articles, completing $1405 \mathrm{G}$. and Sp. as a continuation of the Sylva | Telluriana and North American Trees \& $\mid$ Shrubs, $\mid-1$ by C. S. Rafinesque, A. M.-Ph. D. | Prof. of Botany, the Natural and Histo- I rical Sciences, member of many learned So- I cieties in Europe and America, author of the |New Flora of North America, Flora and | Sylva Telluriana \&c. | Philadelphia | 1838. | price one dollar.

Paper, octavo in size, quarto in fold, pp. [1-3], 4, [5], 6-76.

The cover title reads:

Alsographia | Americana; | or an | American grove | of trees and shrubs. | $\mid$ by C. S. Rafinesque, A. M. - Ph. D. | Prof. of Botany, the Historical and | Natural Sciences \&c. |- | Philadelphia. | 1838. | price one dollar.

See Plate XXVIII.

Copies of this work are in the Library of the New York Botanical Garden; Library of the Gray Herbarium; Library of the Wisconsin State Historical Society; Yale University Library; Library of Congress; Library of the Arnold Arboretum; Library of the Smithsonian Institution; Library of the British Museum; Library of the U. S. Department of Agriculture; Library of the Historical Society of Pennsylvania; and the Fitzpatrick Collection.

884 Rafinesque, C. S.:| Celestial wonders / and philosophy, or | The Structure of the Visible Heavens | with | Hints on their Celestial Religion, | and Theory of Futurity. | by C. S. Rafinesque, 
PLATE XXVII

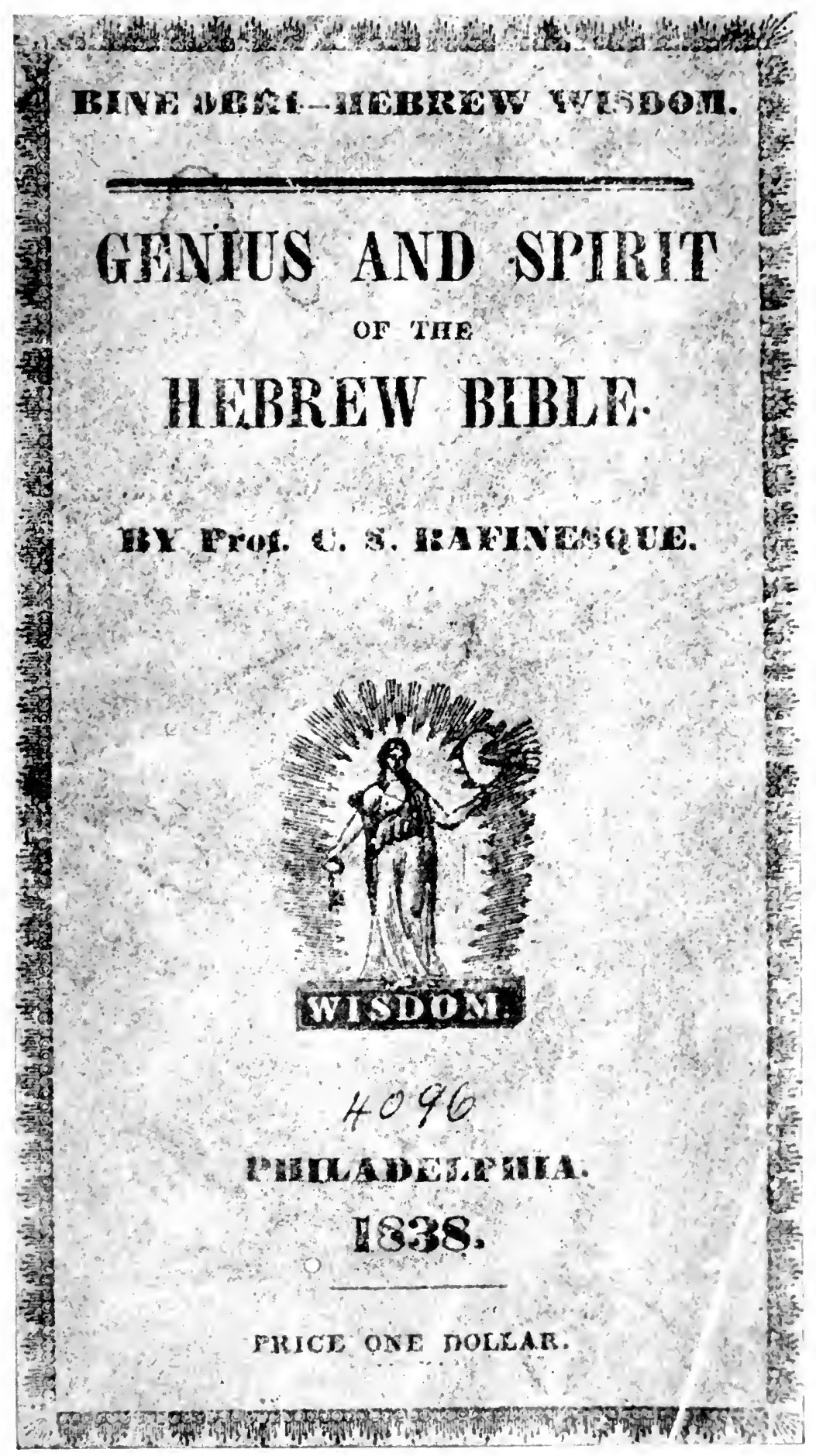

No. 882. Cover title to Rafinesque's work on the "Hebrew Lible" 

PLATE XXVIII

Q4.

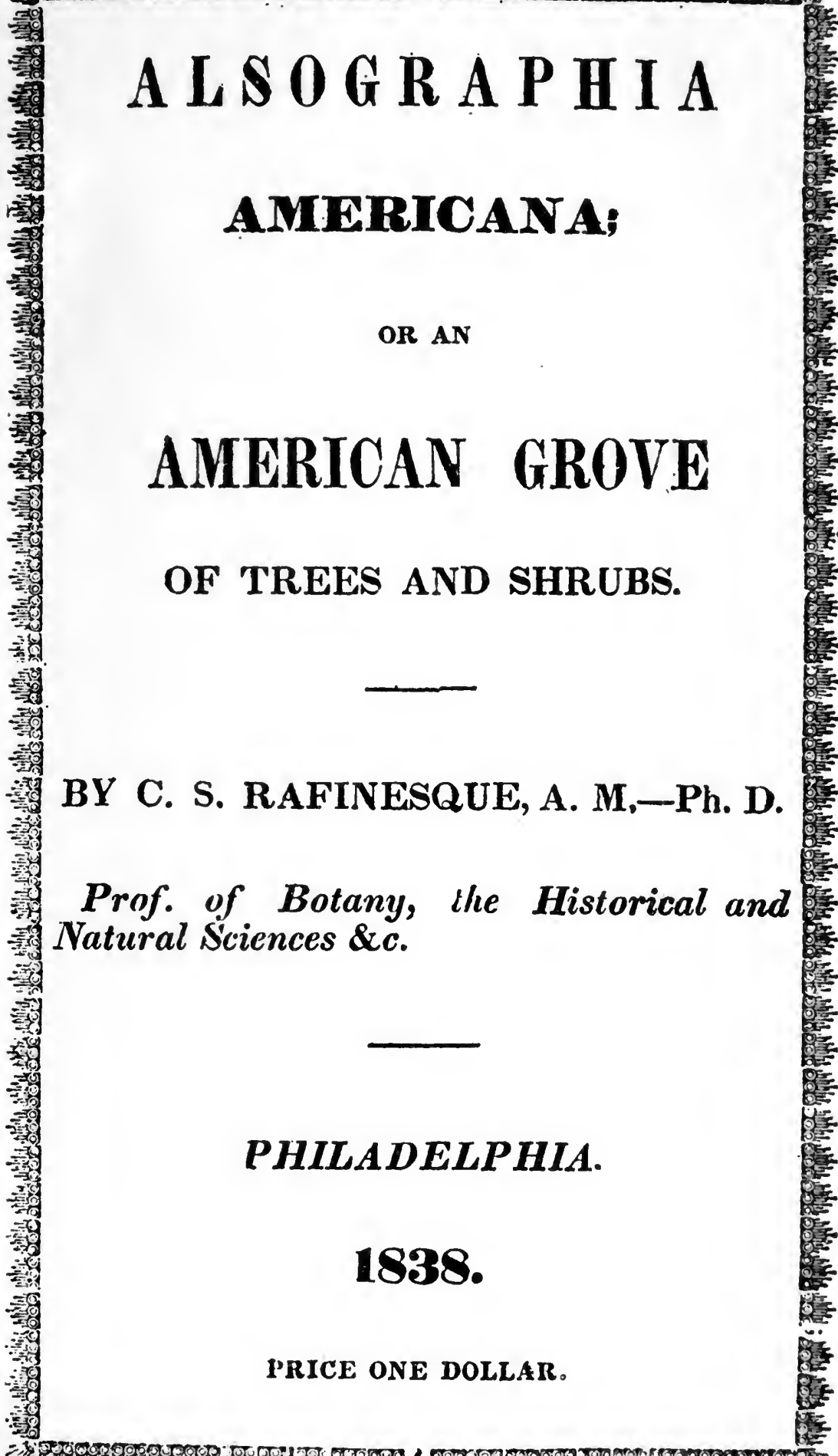

BY C. S. RAFINESQUE, A. M,-Ph. D.

Prof. of Botany, the Historical and Natural Sciences \&c.

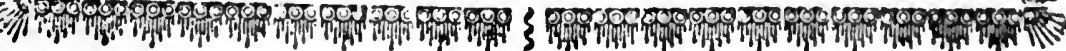

No. 883. Cover title to Rafinesque's "Alsographia Americana" 
Ph. D.-A. M. | Professor of Historical and Natural Sci- ! ences, Member of many learned Societies / in America and Europe, Founder of the | Central University of Illinois \&c, \&c, \&c. | Chiefly derived from the discoveries of $\mid$ the 3 Hershels, and the explanations of $\mathrm{Ni}-\mid$ chol, Mrs. Somerville and others. $1-1$ Thou art not matter, ethereal, unbounded | Ocean of Light. . . . A substance medial Light | Must be, between the heavy matter dull, | And Spiritual unmaterial unseen | Essence or substance filling time and space: | Conceal'd to human eyes, but felt as beams | Of mental rays converging in the souls | That deeply think, and longing ever seek | Eternal life in better worlds of bliss. | | Philadelphia. | 1838. | Printed for the Central University of Illinois. |

Paper, 12mo in size, 6mo in fold, pp. [1-2], 3-135, [136].

See Plate XXIX.

The cover title reads:

Celestial | wonders, | and | philosophy. | by Prof. C. S. Rafinesque. | [cut] | wisdom. | Philadelphia. | | 1838. | price fifty cents. |

Library of the State Historical Society of Wisconsin; Yale University Library; Library of the Arnold Arboretum; Library of the Smithsonian Institution; Library of Congress; The Newberry Library; Library of the Historical Society of Pennsylvania; and the Fitzpatrick Collection.

885 RAFinesQUe, C. S.: | Sylva telluriana. | mantis. synopt. | $=\mid$ new genera and species $\mid$ of $\mid$ trees and shrubs of North America, | and other regions of the earth, | Omitted or mistaken by the Botanical $\mathrm{Au}-\mid$ thors and Compilers, or not properly classified, | now reduced by their natural affinities to the / proper natural orders and tribes. | By C. S. Rafinesque, A. M.-Ph. D. | Prof. of Botany, the Natural and Histo- | rical Sciences, member of many learned socie- | ties, in Paris, Bordeaux, Brussels, Bonn, Vienna, | Zurich, Naples, \&c.-Philadelphia, New York, | Lexington, Cincinnati, \&c., author of many / works. / being a supplement to the flora telluriana. $\mid-1$ (Trees and Shrubs are the Ornaments of the Earth.) $|\longrightarrow|$ Philadelphia: | printed for the author and publisher. $|-| 1838$. $\mid$

Paper, octavo in size, quarto in fold, pp. [1-3], 4-184. Contains with other matter a thousand articles grouped in centuries. The introduction is signed: "Philadelphia, October, 1838." 


\section{CELESTIAL WONDERS}

AND PHLOSOPhy, or

The Structure of the Visible Heavens WITH

Hints on their Celestial Religion, and Theory of Futurity.

BY C. S. RAFINESQUE, Ph. D.-A.M.

Professor of Historical and Natural Sciences, Member of many learned Societies in America and Europe, Founder of the Central University of Illinois \&c, \& c , \& c.

Chiefly derived from the discoveries of the 3 Hershels, and the explanations of $\mathrm{Ni}$ chol, Mrs. Somerville and others.

Thou art not matter, ethereal unbounded

Ocean of Light. . . . A substance medial Light

Must be, between the heavy matter dull,

And Spiritual unmaterial unseen

Essence or substance filling time and space:

Conceal'd to human eyes, but felt as beams

Of mental rays converging in the souls

That deeply think, and longing ever seek

Eternal life in better worlds of bliss.

\section{PHILADELPHIA. 1838. \\ Printed for the Central University of Illinois.}

No. 884. Inner title to Rafinesque's work on "Celestial Wonders and Philosophy"

The cover title reads:

Sylva telluriana | mantissa synoptica. $|=|$ trees and shrubs $\mid$ of $\mid$ North America, | and other parts, | Including about 800 Genera and 1000 species | new or rectified, improved and classified, | by C. S. Rafinesque A. M. - Ph. D., | Prof. of Botany, the Natural and Histo- I rical 
Sciences, Member of many learned $\mid$ Societies \&c. $|-|$ Philadelphia $\mid$ 1838. | Price Five Dollars with the Supplement $\mid-3$ copies for $\$ 10-8$ copies for $\$ 20$. 1

Collation: [title page, p. 1] ; notice, p. [2] ; introduction, pp. [3]-7; centuria I, pp. $8-25$; centuria II, pp. $26-41$; centuria III, pp. $42-57$; centuria Iv, pp. 57-71; centuria v, pp. 71-85; centuria vI, pp. 86-99; centuria viI, pp. 100-113; centuria viII, pp. 113-127; centuria IX, pp. 128-140; centuria X, pp. 141-155; appendix, pp. 155-174, index, pp. 175-184.

Copies of this work are in the Library of the Gray Herbarium; Library of Congress; Library of the Arnold Arboretum; Library of the New York Botanical Garden; Library of the Smithsonian Institution; Library of the British Museum; Library of the U. S. Department of Agriculture; Library of the Historical Society of Pennsylvania; and the Library of the Missouri Botanical Garden.

886 RafinesQue, C. S.: | 1838 Bulletin Nr. 7. | of the | historical and natural | sciences. | By C. S. Rafinesque, A. M.-Ph. D. | Professor of Historical and Natural Sciences. $|-|$ Philadelphia, Spring of 1838. | -

Pamphlet, 16mo in size, quarto in fold, pp. [37], 38-44. The text follows the title.

A copy of this bulletin is in the Library of the New York Botanical Garden; also in the Library of the Arnold Arboretum.

See numbers 851,860 , and 895 .

887 Rafinesque, C. S. The ancient monuments of North and South America, compared with those of the eastern continent. By C. S. Rafinesque, Professor of Historical and Natural Sciences, Ecc. The American Museum of Science, Literature, and the Arts, vol. 1, no. 1, pp. 10-23, Baltimore, September, 1838.

This contribution is dated at the close: "Philadelphia, September, 1838." The subtitle of the first number is: "American Museum of Literature and the Arts, vol. I. September, 1838. No. 1." The editors and proprietors were "Brooks \& Snodgrass." Rafinesque is referred to on page 262.

See number 888 .

888 Rafinesque, C. S. : | The ancient monuments | of | North and South America. | second edition, | Corrected, enlarged and with some additions, | by C. S. Rafinesque, A. M.-Ph. D. | Professor of Historical and Natural Sci- | ences, Member of many' Learned Societies in | Philadelphia, New York, Lexington, Cincin- | natti, Nashville, Paris, Bordeaux, Brussels, | Bonn, V'ienna, 
Zurich, Naples \&c, the Amer- | ican Antiquarian Socicty, the Northern An-| tiquarian Society of Copenhagen \&c. | The massive ruins the arts and skill unfold / Of busy workers, and their styles reveal, | The objects and designs of such divisers; | In silent voices they speak, to thinking minds | They teach, who were the human throngs that left | Uplifted marks for witness of past ages. | Philadelphia | 1838. | Printed for the Author. |

Pamphlet, octavo in size, quarto in fold, pp. [1-3], 4-28. The first edition was published as an article in the "American Museum" of Baltimore, vol. I, no. 1, September, 1838.

Copies of this pamphlet are in the Yale University Library; Library of Arnold Arboretum; Library of the State Historical Society of Wisconsin; The Newberry Library; Library of the University of Pennsylvania; Library of the Historical and Philosophical Society of Ohio; Library of the Historical Society of Pennsylvania; and the Fitzpatrick Collection.

See number 887 .

889 RAFINESQUe, C. S. Letter to Mr. Champollion, on the Graphic Systems of America, and the Glyphs of Otolum, or Palenque, in Central America. Elements of the glyphs. American Antiquities and Discoveries in the West, by Josiah Priest, fifth edition, pp. 123-129, Albany, 1838.

See numbers 821, 832, 844, 852, 877, 926, 931, and 932.

890 [RAFINESQUE, C. S.] Ruins of the City of Otolum, discovered in North America. American Antiquities and Discoveries in the West, by Josiah Priest, fifth edition, p. 246, Albany, 1838.

See numbers $822,833,845,853,878$, and 927.

891 [Rafinesque, C. S.] The Atlantic Nations of America. American Antiquities and Discoveries in the West, by Josiah Priest, fifth edition, pp. 213-315 [313-315], Albany, 1838.

See numbers 825, 836, 847, 854, 879, and 928.

892 RAFINESQUE, C. S. Primitive Origin of the English Language. American Antiquities and Discoveries in the West, by Josiah Priest, fifth edition, pp. 315-322, Albany, 1838.

See numbers $827,838,848,855,880$, and 929.

893 Rafinesque, C. S. [Revieze of the] Ancient Chronology of the Onguys or Iroquois Indians. American Antiquities and 
Discoveries in the West, by Josiah Priest, fifth edition, pp. 335336, Albany, 1838.

See numbers $828,839,849,855 \mathrm{a}, 881$, and 930 .

894 Rafinesque, C. S.: | American manual | of the | mulberry trees. | Their History, Cultivation, Properties, | Diseases, Species and Varieties \&c, | with hints on the production of Silk | from their barks \&c. | by C. S. Rafinesque, A. M. Ph. D. | Professor of Botany, the Historical and | Natural Sciences, Member of several | learned Societies in Philadelphia, New | York, Lexington, Cincinnati \&c, Paris, | Brussels, Bonn, Vienna, Bordeaux, $\mathrm{Zu}$ - $\mid$ rich, Naples \& c. - of the Economical So- | cieties of Vienna and Brussels \&c-Au- | thor of the New Flora and Medical | Flora of the United States, the Vines of | North America and several other Botan- | ical Works. | I I The production of Silk by animal agency is $\mid$ one of the miracles of Nature. $|\longrightarrow|$ Philadelphia | 1839. |

Paper, octavo or 12mo in size, 6mo in fold, pp. [1-3], 4-96.

The above is the inner title, the cover title reads:

Publications of the eleutherium of $\mid$ knowledge, number $5, \mid-1$ American manual $\mid$ of the $\mid$ mulberry trees. $\mid 25$ Species and 30 Varieties, their His- $\mid$ tory, Cultivation, Properties, with hints | on procuring Silk out of the Bark \&c. | - by Prof. C. S. Rafinesque. | - Philadelphia | 1839. | - | Published by the Author for the | eleutherium of knowledge. | Price 50 Cents, twenty copies for $\$ 5 \mid$ and 50 copies for $\$ 10$. |

See Plate XXX.

On the fourth page of cover is given a list of the publications of the Eleutherium of Knowledge: "No. 1, The Universe or Theory of Creation by Thomas Wright, Astronomer, 1750, reprint with notes 1837; no. 2, New Aurora, 5 numbers 1837; no. 3, Celestial Wonders and Philosophy of the Visible Heavens, 1838; no. 4, Genius and Spirit of the Hebrew Bible, 1838; no. 5, Manual of the Mulberry Trees, 1839."

Copies of this work are in the Library of the New York Botanical Garden; Library of the Wisconsin State Historical Society; Library of the Arnold Arboretum; Yale University Library; Library of Harvard University; Library of Congress; Library of the Smithsonian Institution; Library of the New York Botanical Garden; Pennsylvania State Library; The John Crerar Library; Library of the British Museum; Library of the U. S. Department of Agriculture; Library of the Historical Society of Pennsylvania; and the Fitzpatrick Collection.

895 Rafinesque, C. S.: | Bulletin Nr. 9. March 1839. | late 


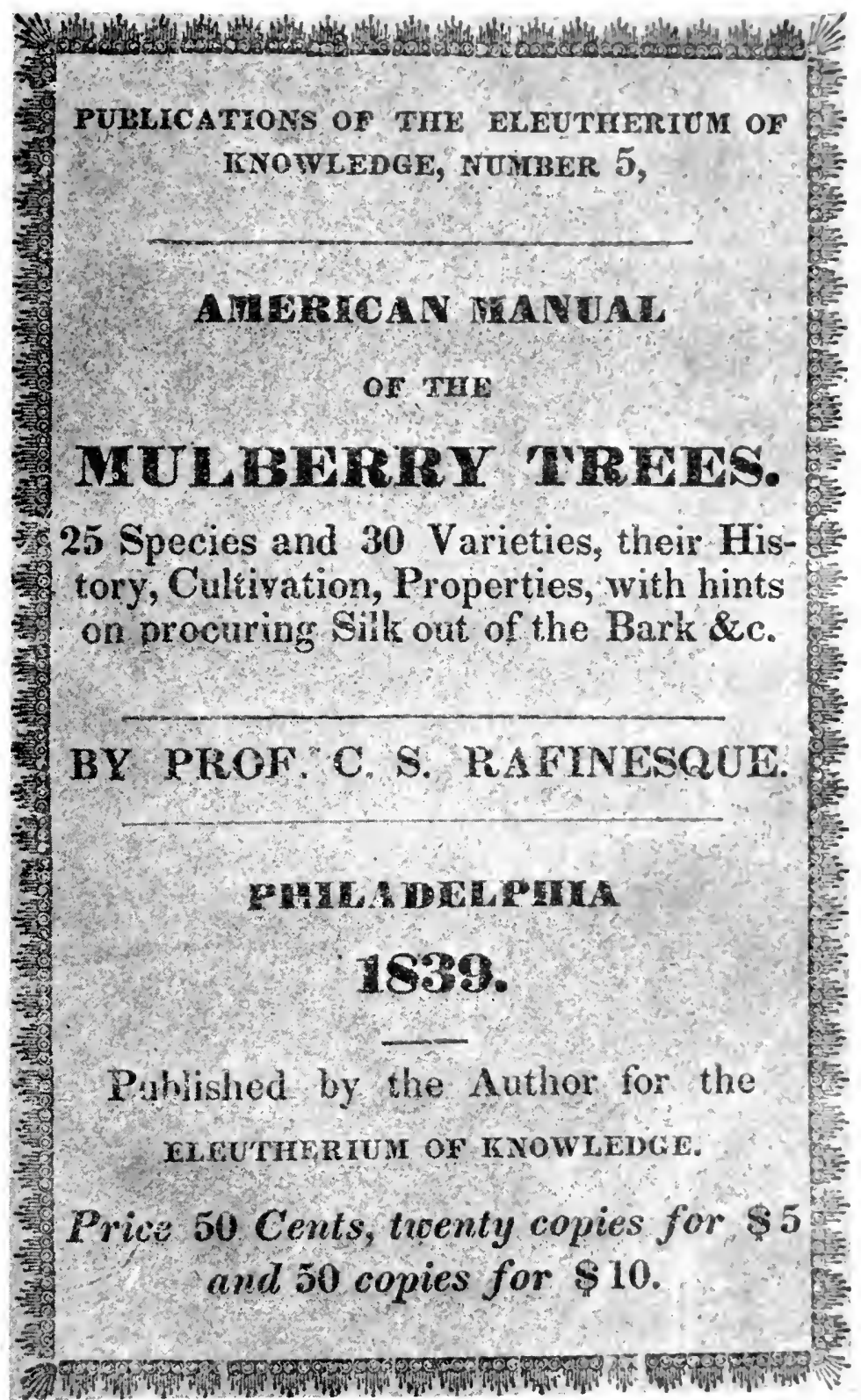

No, 894. Cover title to Ratinesune's ". Mmerican Mammal of Muiberry Trees" 

works. | published by | C. S. Rafinesque. | Professor of Natural Sciences, Botany \&c, | Publisher, Philadelphia 172 Vine Street. |

Leaflet, octavo in size, pp. [1-2]. The text follows the title.

A copy of this bulletin is in the Library of the New York Botanical Garden.

See numbers 851,860 , and 886 .

896 RAFinesque, C. S.: | Improvements | of | universities, colleges, | and other Seats of Learning or Education in | North America. | by C. S. Rafinesque, A. M. Ph. D. | Prof. of Historical and Natural Sciences, | Member of many Learned Societies in Ameri- | ca and Europe, Author of 60 works on various | branches of knowledge \&c. $|\longrightarrow|$ Let us improve! $|-|-\mid$ Philadelphia. | Printed for the Eleutherium of Knowledge | 1839. Distributed Gratuitously.

Pamphlet, octavo in size, of quarto folded sheets, pp. [i-ii], 1-18, and title page. The two closing paragraphs state:

"Philadelphia, written in June 1833, printed June 1839."

"Being N. 6 of the publications of the Eleutherium, for the promotion of free and gratuitous education \&c."

Copies of this pamphlet are in the Library of the Smithsonian Institution; Library of the Missouri Botanical Garden; Library of Congress; and the Fitzpatrick Collection.

897 Rafinesque, C. S.: | Autikon botanikon. Icones Plantarum Select. Nov. vel Rariorum, | plerumque Americana, interdum African. | Europ. Asiat. Oceanic. \&c. | centur. xxv. $\mid=$ botanical illustrations | by Select Specimens of Self-figures in | 25 Centuries of 2500 | Plants, Trees, Shrubs, Vines, Lilies, Grasses, | Ferns \&c, chiefly new or rare, doubtful or in- | teresting, from North American and some other| regions; with accounts of the undescribed, notes, | synonyms, localities \&c. In 5 parts of 5 Centuries each of text with 25 Volumes folio of Self-figures. | by C. S. Rafinesque, | Prof. of Botany, the Historical and Nat- | ural Sciences, member of many learned So- I cieties in America and Europe, author of | many botanical and other zvorks \&c. | first part, cent. I to v. (The best botanical figures are the objects themselves.) $|-|$ Philadelphia. $\mid$ Collected, ascertained and described between | $1815 \& 1840$.

Paper, octavo in size, quarto in fold, pp. [1-2], 3-72. 
The cover title reads:

Autikon botanicon | or | botanical illustrations, | of 2500 | New, rare or beautiful Trees, Shrubs, Plants, | Vines, Lilies, Grasses, Ferns, \&c, of all regions, | but chiefly North America, with descriptions $\mathcal{E c} \mid$ and 2500 self figures or specimens. | by Prof. C. S. Rafinesque. | $-\mid$ first part - - centuries I to v. I text of 500 objects $\mathcal{E}$ articles. | - I 1. Philadelphia. | | $1815-1840$. | Text of each part of 500 objects, 50 cents. $\mid 500$ Figures belonging thereto; 50 dollars. |

Copies of this pamphlet are in the Library of the New York Botanical Garden; Library of the State Historical Society of Wisconsin; Library of the Gray Herbarium; Library of the Arnold Arboretum; Yale University Library; Library of the Missouri Botanical Garden; Library of Congress; Library of the Smithsonian Institution; Library of the U. S. Department of Agriculture; Library of the Historical Society of Pennsylvania; and the Fitzpatrick Collection.

See numbers 898 and 899.

898 Rafinesque, C. S.: $|=|$ Autikon botanikon $\mid$ or $\mid$ botanical illustrations, $\mid$ by self figures of 2500 trees and plants $\mid$ chiefly American. $|=|$ second part,-Centuries vi to x. $\mid$ by C. S. Rafinesque, Prof. | Philadelphia-1815 to 1840. | $=1$

Pamphlet, octavo in size, quarto in fold, pp. [73], 74-140. The above is the inner subtitle. No cover title has been seen by the writer and seemingly none was issued.

Copies of this pamphlet are in the Library of the State Historical Society of Wisconsin; Library of Congress ; Library of the New York Botanical Garden; Yale University Library; Library of the British Museum; Library of the Historical Society of Pennsylvania; and the Library of the Arnold Arboretum.

See numbers 897 and 899.

899 Rafinesque, C. S.: $|=|$ Autikon botanikon | or $\mid$ botanical illustrations, | by self figures of 2500 trees and plants $\mid$ chiefly American. | $\mid$ third part.-centuries xI to xv. | by C. S. Rafinesque, Prof. | Philadelphia 1815 to 1840. $\mid=1$

Pamphlet, octavo in size, quarto in fold, pp. [141], 142-200. The above is the inner subtitle. No cover title has been seen by the writer and probably none was issued.

Copies of this pamphlet are in the Library of the State Historical Society of Wisconsin; Library of the Arnold Arboretum; Library of the New York Botanical Garden; Library of Congress; Library of the Smithsonian Institution; Yale University Library; Library of the Historical Society of Pennsylvania; and the Fitzpatrick Collection.

See numbers 897 and 898. 


\section{THE GOOD BOOK,-NUMBER I}

(300 Figures.)

\section{AMENITIES OF NATURE}

OR ANNALS OF

HISTORICAL AND NATURAI SCIENCES,

Chieffy on Zoology, Botany, Geology. Agronomy, Ethnography, Philology \&c ...: Organized beings and fossils, Nations and Languages. with 1000 figures.

BY C. S. RAFINESQUE A. M.-Ph. D. Professor of those Sciences \& c.

\section{PHILADELPHIA}

January 1840 ,

Subscriptions $\$ 5$ in advance for 10 numbers - single numbers one dollar each.

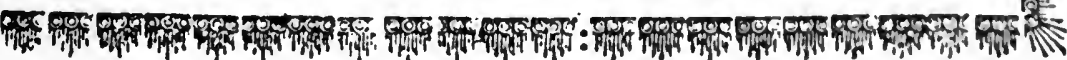

No. 900. Cover title to Rafinesque's "Amenities of Nature" 
900 RAFinesque, C. S.: | The good book, | and amenities of nature, | or annals of historical and natural | sciences. | Containing Selections, of observations, resear- $\mid$ ches and novelties in all the branches of Phy- | sical and Historical Knowledge, with Letters | of eminent Authors-chiefly on Zoology, Botany, | Agronomy, Geognosy, Ethnography ... or Or- I ganized Beings and Fossils, Nations and Lan- | guages. | by C. S. Rafinesque A. MPh. D. | Prof. of Historical and Natural Sciences, | Languages \&c, member of 16 Learned Societies | in Europe and America, author of 220 Works, | Pamphlets, Essays and Tracts . . . I I The works of God to study and explain, Is happy toil and not to live in vain. | | Philadelphia. | 1840. | Printed for the Eleutherium of Knowledge.

Paper, octavo in size, quarto in fold, pp. [1-2], 3-84.

This, the first number of a proposed periodical, was issued January, 1840 , and which was to appear quarterly or semi-annually thereafter. No subsequent numbers appeared. This number was dedicated to William Swainson, Naturalist.

Although mention is made in the text of figures yet none appear.

The cover title reads:

The good book,-number I $\mid$ (300 Figures.) $|=|$ amenities of nature | or annals of | historical and natural sciences, | Chiefly on Zoology, Botany, Geology, Agro- I nomy, Ethnography, Philology \&c . . . Organ| ized beings and fossils, Nations and Languages. | with 1000 figures. | by C. S. Rafinesque A. M.-Ph. D. I Professor of those Sciences \&c. $|-|$ Philadelphia | January 1840. | Subscriptions $\$ 5$ in advance for 10 numbers $\mid$-single numbers one dollar each. |

See Plate XXXI.

The contents all written by Rafinesque are:

901 Title page, p. 1 ; prospectus, p. 2 ; introduction, pp. 3-4.

9021 , Article, classification of the natural sciences and objects, pp. $5-12$.

903 2, Eutaxy, theory of classification and the new science of eutaxy or methodology, pp. 12-16.

9043 , Analogies, the circle of natural objects, or collective affinities and analogies of corporeal forms-a new science, pp. 16-19.

9054 , Botany, on a new natural class of plants, the antines or endantines, pp. 19-23.

906 5, Botany, the natural family of Carexides, pp. 23-28.

9076 , Zoology and geology, the Adelostomes and their geological formations, with 45 figures, pp. 28-36. 
908 7, American botany, remarks on the flora of North America by Torrey, Grey [Gray] and Nuttal [Nuttall], pp. 37-44.

9098 , New flora and botany of North America or a supplenental flora, to all the botanical works on the United States, by C. S. Rafinesque, Philad., 1836, pp. 44-47.

910 9, New trees and shrubs of North America, pp. 47-49.

911 10, Scadiography or 100 G. of Ombelliferous plants chiefly new, with their types \&c, pp. 49-61.

912 11, On the 5 genera Torreya \&c, pp. 61-63.

913 12, On the 3 genera of Cephalopodes, Ocythoe, Todarus, and Anisoctus, pp. 63-65.

914 13, Ditaxopus paradoxus, a new fossil G. of Cephalopodes, discovered 1819-figure[s] 54 and 55, shell and animal, pp. 66-67.

915 14, The new quadrupeds of North America, described in my Atlantic Journal of 1832, pp. 67-68.

916 15, Etymology of the Origon mountains, p. 68.

917 16, Historical and ethnographical palingenesy, \&c, pp. 68-70.

91817 , Monuments of the Atlantes, with an inscription 4000 years old-with figures 62 to 68 , pp. 71-76.

919 18, The graphic systems of the ancient American and Chinese nations, pp. 76-81.

920 19, Agronomy-oils of India, pp. 81-83.

921 2[0], Additions, p. 83.

Index to number I, p. 84 .

Copies of this volume are in the Library of the New York Botanical Garden; Library of the State Historical Society of Wisconsin; Library of the Gray Herbarium; Yale University Library; Library of the Arnold Arboretum; Library of the Smithsonian Institution; Library of Congress; Library of the Office of Surgeon-General; Library of the U. S. Department of Agriculture; Library of the Historical Society of Pennsylvania; and the Library of the British Museum.

922 RaFinesque, C. S.: | The / pleasures and duties | of wealth. | by C. S. Rafinesque. | A. M.-Ph. D. | Professor of historical and natural Sciences, I member of many learned Societies in | France, Germany, Belgium, Denmark, | Szvitzerland, Italy and the United $\mid$ States, \&c. Author of many $\mid$ works, \& c. $|-|$ In deeds of good import your wealth employ, | And happiness bestow, yourselves enjoy. $|-|-\mid$ Philadelphia: | printed for the eleutherium of knowledge $|-| 1840$.

Pamphlet, octavo in size, quarto in fold, pp. [1-2], 3-32.

Copies of this pamphlet are in the Library of the Arnold Arboretum; Library of the State Historical Society of Wisconsin; Library of Congress; Library of the Smithsonian Institution; Library of the British 
Museum; Library of the Historical Society of Pennsylvania; and the Fitzpatrick Collection.

923 Rafinesque, C. S. Remarks on the Physical Geography of North America. By C. S. Rafinesque. Philadelphia, April, 1840. The Journal of the Royal Geographical Society of London, vol. 11, pp. 165-171, London, 1841.

This is probably the last contribution by Rafinesque to a foreign medium that was published.

924 [RAFinesque, C. S. Remarks on New Colonies.] The Journal of the Royal Geographical Society of London, vol. 11, p. 171, London, 1841.

An abstract of the article by the editor of the journal. The article predicts the American occupation of Lower California and contiguous territory.

925 Rafinesque, Professor [C. S.] : | Manual | of the | medical botany | of the | United States; | containing | a description of fifty-two medical plants, with their | names, qualities, properties, history, \&c. | with | remarks on nearly 500 substitutes | and | fiftytwo coloured plates. $|-|$ By Professor Rafinesque, A. M. | - Philadelphia : | 1841. |

Sheep, $12 \mathrm{mo}$ in size, $6 \mathrm{mo}$ in fold, pp. [ia-iva, i], ii-xii, [1], 2-259, plates 1-52.

See Plate XXXII.

The collation is: p. [ia], title page; p. [iia], blank; pp. [iiia-iva], table of contents; pp. [i]-xii, introduction; pp. [1]-24, general principles of medical botany; pp. 25-259, body of the work.

This volume is a reissue of volume I of the Medical Flora issued in 1828. The only difference between the two volumes is in the title pages and pages [ia-iva], and the omission of pages 261-268.

See numbers 554, 557, and 933.

Copies of this work are in the Library of the Gray Herbarium; Library of the Office of the Surgeon-General; and the Fitzpatrick Collection.

926 RAFinesque, C. S. Letter to Mr. Champollion, on the Graphic Systems of America, and the Glyphs of Otolum, or Palenque, in Central America. American Antiquities and Discoveries in the West, by Josiah Priest, fifth edition, pp. 123-129, A1bany, 1841.

See numbers $821,832,844,852,877,889,931$, and 932.

927 [RAFINESQUE, C. S.] Ruins of the City of Otolum, discovered in North America. American Antiquities and Discov- 


\section{A N U A L}

of THE

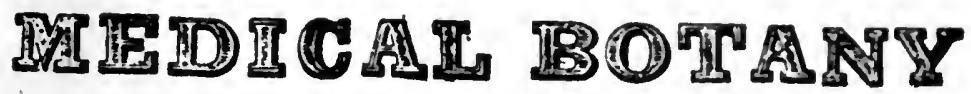

\section{or THE

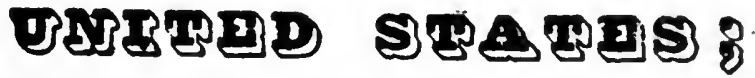

coxtainixa

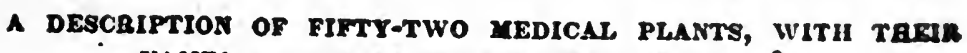
NAMES, QUALITIES, PROPERTAS, HISTORY, \&c.

wITH

REMARKS ON NEARLY 500 SUBSTITUTES

AxD

FIFTY-TWO COLOURED PLATES.

By Professor RAfinesque, A. M.

PHILADELPHIA :

1841.

No. 925. Title to Rafinesque's "Manual of Medical Botany" 
eries in the West, by Josiah Priest, fifth edition, p. 246, Albany, 1841.

Contains an extract from a letter by Rafinesque.

See numbers $822,833,845,853,878$, and 890 .

928 [Rafinesque, C. S.] The Atlantic Nations of America. American Antiquities and Discoveries in the West, by Josiah Priest, fifth edition, pp. 213-315 [313-315], Albany, 1841.

See numbers 825, 836, 847, 854, 879, and 891.

929 Rafinesque, C. S. Primitive Origin of the English Language. American Antiquities and Discoveries in the West, by Josiah Priest, fifth edition, pp. 315-322, Albany, 1841.

See numbers $827,838,848,855,880$, and 892.

930 Rafinesque, C. S. [Review of the] Ancient Chronology of the Onguys or Iroquois Indians by David Cusick. American Antiquities and Discoveries in the West, by Josiah Priest, fifth edition, pp. 335-336, Albany, 1841.

See numbers $828,839,849,855 \mathrm{a}, 881$, and 893 .

931 Rafinesque, C. S. Ancient languages of the first inhabitants of America. Letter to M. Champollion, on the Graphic Systems of America, and the Glyphs of Otolum or Palenque, in Central America.-By C. S. Rafinesque. In Rambles in Yucatan, by B. M. Norman, second edition, pp. 292-296, New York, 1843.

See numbers 821, 832, 844, 852, 877, 889, 926, and 932.

932 RAFINESQUE, C. S. Ancient languages of the first inhabitants of America. Letter to Mr. Champollion, on the Graphic Systems of America, and the Glyphs of Otolum or Palenque, in Central America.-By C. S. Rafinesque. In Rambles in Yucatan, by B. M. Norman, seventh edition, pp. 292-296, Philadelphia, 1849.

See numbers $821,832,844,852,877,889,926$, and 931.

933 Rafinesque, C. S. Medical Flora. Philadelphia, 1850, 2 vols., $12 \mathrm{mo}$, boards, colored plates.

The writer has not seen a copy of this work. Luther S. Livingston in volume III of Auction Prices of Books states that a copy was sold at the Alexander sale, March, 1895. If such a work exists it is probably a reissue of volumes I and II of the Medical Flora, 1828-30, in the same manner as the volume of the Manual of Medical Botany of the United States, issued in 1841.

See numbers 554, 557, and 925. 
934 RAFInESQUE, C. S.: | Monographie | des | coquilles | bivalves fluviatiles | de la rivière Ohio | par | M. C. S. Rafinesque, | Professeur d'Histoire naturelle à l'université transylvane de Lexington. | [cut] | Paris, | A. Franck, libraire-editeur, | rue richelieu, 69. $|-| 1845$

Small quarto in size, octavo in fold, pp. [1-7], 8-30, [31, 32 blank], frontispiece, plates $1-3$.

The copy examined is in the Library of Congress.

See numbers 344, 363, and 608.

935 RAFInesQue, C. S.: | The | complete writings | of | Constantine Smaltz Rafinesque, | on | recent \& fossil | conchology. - $\mid$ edited by $\mid$ Wm. G. Binney, and George W. Tryon Jr., Members of the Academy of Natural Sciences of Philadelphia. — New York: | Bailliere brothers, 520 Broadway. | London: H. Bailliere, 219 Regent Street. | Paris: J. B. Bailliere, et Fils, Rue Hautefeuille. | Madrid: C. Bailly Bailliere, Calle del Principe. $\mid$ 1864. |

Paper, octavo in size and fold, pp. [1-5], 6-96, [1], 2-7, plates 3. The cover and inner titles are identical.

936 RAFinesque, C. S. Chants anciens des Indiens des EtatsUnis. (Extrait de l'ouvrage intitulé: The American Nations, or outlines of their general history, ancient and modern, etc. by C. S. Rafinesque, Philadelphia, 1836, first volume, pag. 122 et suiv.) In Collection de documents dans les langues indigènes pour servir a l'étude de l'histoire et de la philologie de l'Amérique ancienne, volume quatrième, quatre lettres sur le Mexique par M. Brasseur de Bourbourg, pp. [435]-448, Paris, 1868.

937 RAFInESQUe, C. S.: | Ichthyologia Ohiensis | or Natural History of the / Fishes Inhabiting the River / Ohio and its Tributary Streams / by |C. S. Rafinesque /A verbatim et literatum reprint of $\mid$ the original, with a Sketch of the Life, | the Ichthyologic Work, and the Ich- | thyologic Bibliography of Rafinesque | by | Richard Ellsworth Call, M. Sc. M. A. M. D. Ph. D | [cut] | Cleveland | The Burrows Brothers Co | 1899 |

Cloth, octavo in size and fold, pp. [1-11], 12-175, portrait, figure. The first line and the cut are rubricated.

See number 337 and Bibliotheca Rafinesquiana, number 24.

938 RAFinesque, C. S. Remarks on the Encyclopredia of 
Plants of Loudon, Lindley, and Sowerby. The Journal of Botany, British and Foreign, vol. xxxviII, pp. 225-229, London, June, 1900.

A reprint of the article which appeared in Loudon's Gardener's Magazine, vol. viII, pp. 244-248, London, 1832.

See number 605 .

939 RAFinesque, C. S.: | Annals of nature | or | Annual Synopsis | of new genera and species of animals, plants, \&c. | discovered in North America |- $\mid$ By C. S. Rafinesque | [cut] | Privately Reprinted | By T. J. Fitzpatrick | Iowa City, Iowa | January 15, 1908 |

Paper, octavo in size and fold, pp. [i-ii], [1]-16.

Contents : title, p. [i] ; foreword, p. [ii]; reprint, pp. [1]-16.

See number 370 .

\section{MANUSCRIPTS}

The manuscript materials left by Rafinesque and those relating to him are various and widely scattered. It is unknown to the writer what has become of many of them.

940 RAFinesQue, C. S.: | Outlines | of a General History of America $\mid$ By C. S. Rafinesque $|=|$ Second Chronological Part $\mid$ - | Colunal Annals | of the | Antillary or West Indies | Islands | also Guyana and Brazil | besides the Boreal and Austral Islands $\mid$ or the whole of America | except | Spanish America and North America | - From 1492 to 1775. | Begun in Philadelphia, in October 1827.

The title of an unpublished manuscript preserved in the Library of Congress. The prospectus only was published.

See number 857.

941 RaFinesque, C. S. A manuscript of the Walum Olum consisting of forty unnumbered small quarto leaves in the handwriting of Rafinesque. The two parts with their titles as given below are taken from The Lenapé and their Legends with the complete text and symbols of the Walam Olum by Daniel G. Brinton, Philadelphia, 1885, p. 162.

The first title reads:-

Wallamolum.

First Part of the painted-engraved | traditions of the Linni linapi. \&c. | 
containing | the 3 original traditional poems. | I. on the Creation and Ontogony, 24 verses. $\mid 2$. on the Deluge, \&c. 16v. |3. on the passage to America, $20 \mathrm{v}$. | Signs and Verses, 60 | with the original glyphs or signs | for each verse of the poems or songs | translated word for word | by C. S. Rafinesque | 1833.

The title to the second part reads:-

Wallam-OLum.

First and Second Parts of the | Painted and engraved traditions | of the Linni linapi.

II. Part.

Historical Chronicles or Annals | in two Chronicles.

I. From arrival in America to settlement in Ohio, \&c. 4 chapters each of 16 verses, each of 4 words, 64 signs.

2d. From Ohio to Atlantic States and back to Missouri, a mere succession of names in 3 chapters of 20 verses -60 signs.

Translated word for word by means of Zeisberger and Linapi Dictionary. With explanations, \&c.

By C. S. Rafinesque. 1833.

The Walam olum, | or | red score, | of the | Lenâpé. | is given on pages 169-217 of Brinton's work mentioned above.

The original manuscript has not been seen by the writer. In the Lenox Library is a transcript of the original. From this the first title reads as follows:

Wallamolum | First Part of the painted engraved tradi- | tions of the Linni linapi \&c | Containing | the 3 original traditional poems $\mid 1$. On the creation and antogony 24 verses $\mid 2$. On the deluge \&c $16 \mid 3$. On the passage to America $20|-|$ Signs \& verses $60 \mid$ with the original glyphs or signs for | each verse of the poems or songs | translated word for word | by C. S. Rafinesque | 1833 | This MS \& the wooden original was procured | in 1822 in Kentucky, but was inexplicable | till a deep study of the Linapi enabled me $\mid$ to translate them, with explanations. |

The title to the second part reads:

Wallam-Olum $|=|$ First and Second Parts of the Painted $\mid$ and engraved traditions of the Linnilinapi. | - II Part | Historical Chronicles or Annals in | two Chronicles. | 1. From arrival in America to settlement | in Ohio \&c 4 chapters, each of 16 verses, | each of 4 words. 64 signs | 2. From Ohio to Atlantic States \& back to Mis- | souri, - a mere succession of names in 3 | chapters of 20 verses, -60 signs $/$ translated word for word, by means of Zeis- | berger and Linapi Dictionary, with expla- | nations \&c | By C. S. Rafinesque - 1833 |

The manuscript is of forty unnumbered quarto leaves.

It will be noticed that Brinton's title and the above vary in a number of particulars. 
Twenty four lectures on the natural history of the universe, the earth and mankind, animals and plants.

This was in the possession of S. S. Haldeman in 1842. Of it he says: "These unpublished lectures are in our possession; they treat of astronomy, meteorology, geology, mineralogy, crystallography, \&c. Nine of them constitute the zoological portion, and indicate but little talent. The introductories are good, and those devoted to American geology amusing, from the singularity of the views advanced."-American Journal of Science, vol. 42 , p. 288.

Fishes of the Susquehanna. (Haldeman, 1. c.)

In the Library of the Smithsonian Institution are ten manuscript notebooks of Rafinesque which contain hasty sketches of fishes, mice, plants, etc., as well as notes jotted down from time to time and outlines of projected articles or treatises. In one will be found:

Journal of my Travels in 1826 which is mostly notes of the day's happenings from April 9th to June 4th and covers eight pages of manuscript. It details events during the journey from Lexington northward through Ohio and eastward into New York when Rafinesque made his last trip from the west.

Another notebook has the following title:

Comparative Decimals | in all the principal Languages | and Dialects of the Earth. $|-|$ By C. S. Rafinesque $|-|$ Begun in Lexington $\mathrm{Ky} .1822$.

The back part of this notebook has the following title:

Views, Maps \& Sketches $\mid$ of my travels $\mid$ in $1832,33,34$ \&c | — C. S. Rafinesque |

This is mostly made up of rough notes, sketches of scenes, and of natural objects.

Letter of Rafinesque to Amos Eaton, dated March 15, 1818. In the Fitzpatrick Collection.

Long letter from Rafinesque, dated Frankfort, Ky., Nov. 24, 1825 , to Mr. J. Cohen, Baltimore, concerning the divitial principle or invention. In the Fitzpatrick Collection.

Various letters of Rafinesque are in the Library of the New York Botanical Garden, also in the Library of the Wagner Free Institute of Science and the Lloyd Library. 
Indice d'Ittiologia Siciliana, 1810.

A transcript, apparently prepared many years ago in Madrid, Spain, later passed to Berlin, Germany, and finally into the Fitzpatrick Collection.

Other transcripts in the Fitzpatrick Collection are:

Transcripts of articles from Desvaux's Journal de Botanique, vols. $1,2,3,4,1808-1814$.

Précis des découvertes et travaux somiologiques, 1814.

Analyse de la nature ou tableau de l'univers et des corps organisés, 1815.

Circular address on botany and zoology, 1816.

Florula ludoviciana; or, a flora of the state of Louisiana, 1817.

Transcript of articles in Western Review and Miscellaneous Magazine, vols. 1-3, 1819-1820.

Annals of Nature or annual synopsis of new genera and species of animals, plants, \&c., discovered in North America, 1820.

First catalogues and circulars of the botanical garden of Transylvania university at Lexington in Kentucky, 1824.

Transcript of articles in The Cincinnati Litcrary Gazette, vols. $1-3,1824-1825$.

Neogenyton, or indications of sixty-six new genera of plants of North America, 1825.

Journals of my travels in 1826.

Enumeration and account of some remarkable natural objects in the cabinet of Professor Rafinesque, 1831.

Continuation of a monograph of the bivalve shells of the river Ohio and other rivers of the Western states, 1831.

Statements respecting the divitial institution of North America, and six-per-cent savings bank, 1835.

Bulletin of the historical and natural sciences, nos. 1, 3, 7, 9, 1834-1839.

Alsographia Americana, 1838.

Autikon botanikon, parts 2 and 3, 1840.

The good book, and amenities of nature, or annals of historical and natural sciences, 1840.

The ancient monuments of North and South America, a transcript from The American Museum of Science, Literature, and the Arts, vol. 1, no. 1, pp. 10-23, 1838. 

BIBLIOTHECA RAFINESQUIANA 



\section{BIBLIOTHECA RAFINESQUIANA}

The following list of references concerning Rafinesque contains only such items as the writer has seen while searching for the necessary material to compose the biographical sketch of Rafinesque and to compile a bibliography of his writings. The one hundred and thirtynine numbers here given comprise a wide range of literature which frequently refers to Rafinesque only incidentally.

1 Agassiz, L.[ouis] : | Notice | of a | collection of fishes | from the southern bend $\mid$ of the $\mid$ Tennessee river, Alabama. | By L. Agassiz. | - extracted from the American journal of science and arts, volume xvir, second $\mid$ series. -1854 . $|-|$ New Haven: | printed by B. L. Hamlen, | Printer to Yale College. | $-\mid 1854$. $\mid$

Paper, octavo in size and fold, pp. [1-3], 4-31. The cover and inner titles are identical.

2 Agassiz, L.[ours]. Notice of a collection of Fishes from the southern bend of the Tennessee River in the state of Allabama. American Journal of Science and Arts, 2d series, vol. xvir, no. 50, pp. 297-308, March, 1854; also no. 51, pp. 353-365, May, 1854.

Discusses incidentally various genera of fishes proposed by Rafinesque in his Ichthyologia Ohiensis. Also gives a friendly view of Rafinesque and his work.

3 [AldRich, Charless]. A forgotten naturalist. Annals of Iowa, vol. vir, no. 3, p. 230, October, 1905.

4 Allen, H.[arrison]. Monograph of the Bats of North America. Smithsonian Miscellaneous Collections, vol. vir, pp. xvi-xvii, 12, 14-15, 71-73, Washington, June, 1864.

On pages 71-73 are reproduced Rafinesque's descriptions of bats to be 
found in the American Monthly Magazine, vol. 3, p. 445, 1818, and Annals of Nature, pp. 2-3, 1820.

5 Alles, Harrison. A Monograph of the Bats of North America. Bulletin of the United States Museum, no. 43, pp. 183184, Washington, 1893.

Reproduces Rafinesque's descriptions of bats to be found in the American Monthly Magazine, vol. 3, p. 445, 1818, and Annals of Nature, pp. 2-3, 1820.

6 Alimbone, S. Austin. [A sketch of the life and works of] Constantine Schmaltz Rafinesque. In A Critical Dictionary of English Literature and British and American Authors, vol. II, p. 1724, 1891.

7 Anonymous. [Review of the] "Ancient History, or Annals of Kentucky," etc. The Cincinnati Literary Gazette, vol. II, no. 26, pp. 202-204, December 25, 1824.

This article is a quite lengthy satirical review, intended to cast ridicule upon Rafinesque. It is unsigned and was probably written by John F. Foote, the publisher of the Gazette.

8 Audubon, John James. The Eccentric Naturalist. Ornithological Biography, vol. I, pp. 455-460, Philadelphia, 1832.

Gives a lively account, doubtless with exaggeration, of a three weeks visit of [Rafinesque] M. de T. to the home of Audubon on the Ohio river.

9 Audubon, Mrs. J. J. The Life of John James Audubon, the Naturalist, edited by his widow, with an introduction by Jas. Grant Wilson, pp. 67-70, New York, 1879.

10 Barnhar'T, JoHn HENDley. The dates of Rafinesque's New Flora and Flora Telluriana. Torreya, vol. 7, no. 9, pp. 177182, New York, September, 1907.

Concludes that the dates of issue of Rafinesque's New Flora were: Part I, 1836, December; Part II, 1837, second half; Part III, 1838, first quarter; Part IV, 1838, late in the year. Also that the dates of issue for Flora Telluriana were: Part I, 1837, first quarter; Part II, 1837, first quarter; Part III, 1837, November or December; Part IV, 1838, near middle of the year.

11 Barnhart, John HEndley. Some American botanists of former days. Journal of the New York Botanical Garden, vol. x, no. 116, pp. 177-190, August, 1909.

12 B.[EBB], M. S. More about Rafinesque. The Botanical Gazette, vol. virr, no. 3, pp. 191-192, March, 1883. 
13 Binney, W. G. and Biand, Thomas. [Note on] Mesodon leucodon of Rafinesque. Annals of the Lyceum of Natural History of New York, vol. Ix, pp. 294-295, New York, 1870.

14 Binney, Amos. The Terrestrial Air-breathing Mollusques of the United States, edited by Augustus A. Gould, vol. 1, pp. 36, 38-39, 41-55, 57-58, Boston, 1851.

A rather prejudiced author.

15 Bradford, Mary Fluker. [A sketch of] Audubon, pp. 35-36, New Orleans, 1897.

16 BRENDEL, FREDERICK. Historical Sketch of the Science of Botany in North America from 1635 to 1840 . The American Naturalist, vol. xIII, no. 12, pp. 764-765, December, 1879.

A short sketch in which the writer shows prejudice and a lack of knowledge.

17 Brinton, Danies G. The Lenâpé and their Legends; with the complete text and symbols of the Walam Olum, a new translation, and an inquiry into its authenticity, Philadelphia, 1885.

See chapter vil, pp. 148-217. This chapter contains a short biographical sketch of Rafinesque, an evaluation of his writings, an account of the Walam Olum, its genuineness, a bit of Rafinesque's character, conclusions, etc., followed by the original text and a translation of the Walam Olum.

18 BRITTEN, JAMES. Bibliographical Notes. XXIII.-An Overlooked Paper by Rafinesque. The Journal of Botany, British and Foreign, vol. xxxviII, pp. 224-225, London, June, 1900.

The paper follows in reprint, pp. 225-229, and is entitled: "Remarks on the Encyclopædia of Plants of Loudon, Lindley, and Sowerby."

A news item concerning this may be found in The Botanical Gasette, vol. $\mathrm{xxIx}$, no. 6, p. 448, June, 1900.

See numbers 605 and 938.

19 Britron, N. L. The Genus Hicoria of Rafinesque. Bulletin of the Torrey Botanical Club, vol. xv, no. 11, pp. [277]-285, November, 1888.

20 B. [urnetT, David G.] A card. To C. S. Rafinesque, D. P. \&c. \&c. Modern Catesby, B. P. T. U. D. K. \&c. The Cincinnati Literary Gazette, vol. I, no. 23, p. 183, June 5, 1824.

21 B.[URnetT, David G.] Indians of Texas. The Cincinnati Literary Gazette, vol. II, no. 1, p. 3, July 3, 1824.

22 B. [URNeTT, David G.] A brief desultory and imperfect vocabulary of the Comanchee language; respectfully dedicated to 
Professor Rafinesque of Transylvania University. The Cincinnati Literary Gazette, vol. II, no. 1, pp. 3-4, July 3, 1824.

23 Call, R. ElLsworth. Note on the genus Campeloma of Rafinesque. The American Naturalist, vol. xvir, no. 6, pp. 603608, June, 1883.

24 Cali, R. Elissworth. On the Genus Campeloma, Rafinesque, with a Revision of the Species, Recent and Fossil. Bulletin of the Washburn College Laboratory of Natural History, vol. I, no. 5, pp. [149]-165, May, 1886.

25 Call, Richard Ellisworth: | Ichthyologia Ohiensis | or Natural History of the / Fishes Inhabiting the River | Ohio and its Tributary Streams | by |C. S. Rafinesque |A verbatim et literatim reprint of | the original, with a Sketch of the Life, | the Ichthyologic Work, and the Ich- | thyologic Bibliography of Rafinesque | by $\mid$ Richard Ellsworth Call, M. Sc. M. A. M. D. Ph. D | [cut] Cleveland | The Burrows Brothers Co | 1899 |

Cloth, octavo in size and fold, pp. [1-11], 12-175, portrait, figure. The first line and the cut are rubricated.

Contents : preface, pp. [11]-13; biographic sketch, pp. [15]-23; ichthyologic work, pp. [25]-36; text of Rafinesque's Ichthyologia Ohiensis, pp. [37]-162; bibliographia Ichthyologia, pp. [163]-172; appendix, pp. [173]175 .

26 Call, Richard Elisworth: | Author's edition | Filson Club Publications No. 10 | The Life and Writings | of | Rafinesque | Prepared for the Filson Club and read at its Meeting | Monday, April 2, 1894 | By Richard Ellsworth Call, M. A., M. Sc., M. D. | Member of the Filson Club | [cut] | Louisville, Kentucky | John P. Morton and company | Printers to the Filson Club | 1895 |

Paper, quarto in size and fold, pp. [i-v], vi-xii, [1], 2-227, portraits, plates. The first and fifth lines of the title as well as the cut are rubricated.

The cover title reads:

Author's edition $|-|$ Filson Club Publications $\mid$ number ten $|=|$ The Life and Writings $\mid$ of $\mid$ Rafinesque $|=|$ By | Richard Ellsworth Call, M. A., M. Sc., M. D. $\mid-1$

27 CALL, R. Elisworth. An unpublished letter of Rafinesque. Science, new series, vol. xv, no. 383, pp. 713-714, May 2, 1902.

Gives letter to Manasseh Cutler, dated Palermo, 2nd May, 1806. 
28 Chase, Theodore R. Constantine Schmaltz Rafinesque. Potter's American Monthly, an Illustrated Magazine of History, Literature, Science, and Art, vol. vi, no. 50, pp. 97-101, Philadelphia, February, 1876.

Gives a portrait and reproduction of the gold medal won by Rafinesque. A very appreciative article.

29 Collins, LEwis. [Sketch of Constantine S. Rafinesque]. History of Kentucky, vol. II, pp. 201-202, Covington, Ky., 1874.

Further references to Rafinesque occur on pages 12, 185, 302, and 548. On pages 302-303 is a description of the ancient monuments of Kentucky by C. S. Rafinesque which has been condensed by Mr. Collins. On pages 392-393 of volume I an annotated list of the sites of the ancient monuments of Kentucky by Rafinesque is reprinted.

The one volume edition of Collins' history of Kentucky, issued at Cincinnati in 1850, apparently contains nothing with reference to Rafinesque.

30 Conrad, T. A. A Synopsis of the Family of Naïles of North America, with Notes, and a Table of some of the genera and sub-genera of the Family, according to their geographical distributions of genera and sub-genera. Proceedings of the Academy of Natural Sciences of Philadelphia, vol. vi, pp. 243-269, Philadelphia, February, 1853.

An article in which an attempt is made to give due credit to the labors of Rafinesque. A rejoinder was given by Isaac Lea. See number 97 .

31 Copeland, Herbert E. A Neglected Naturalist. The American Naturalist, vol. x, no. 8, pp. 469-473, August, 1876.

Considers intelligently and amicably Rafinesque's work on the fishes of the Ohio river.

32 [Coulter, John M.] Some North American Botanists, I. C. S. Rafinesque. The Botanical Gazette, vol. viII, no. 1, pp. [149]-152, January, 1883.

33 [COULTER, John M. A news item concerning Rafinesque's article on "Remarks on the Encyclopædia of Plants of Loudon, Lindley, and Sowerby."] The Botanical Gazette, vol. xxıx, no. 6, p. 448, June, 1900.

34 Cutler, Manasseh. Life, Journals, and Correspondence of Rev. Manasseh Cutler, LL. D., by his grandchildren William Parker Cutler and Julia Perkins Cutler, vol. II, pp. 311-314, Cincinnati, 1888.

Contains an extended letter from Rafinesque addressed to Doctor $M$. 
Cutler and dated: "Palermo, Jan. 28, 1807." Speaks of his work, plans, and American interests.

35 Cutler, William Parker and Cutler, Julia Perkins. [Sketch of Rafinesque.] In Life, Journals, and Correspondence of Rev. Manasseh Cutler, vol. II, pp. 311-312, Cincinnati, 1888.

A short sketch given as a footnote.

36 Dali, William H. Some American Conchologists. Constantine Samuel Rafinesque-Schmaltz. Proceedings of the Biological Society of Washington, vol. IV, pp. 114-118, Washington, 1888.

Annual presidential address, delivered at the Eighth Anniversary meeting of the Biological Society, January 28, 1888.

37 Darlington, William. Reliquix Baldwinianæ: selections from the correspondence of the late William Baldwin, M. D., Philadelphia, 1843, pp. [15], 18, 280, 282, and 300-301.

38 Darlington, William. Memorials of John Bartram and Humphrey Marshall with notices of their botanical contemporaries, Philadelphia, 1849, pp. 25-26.

39 Desvaux, N. A. Remarks sur les différens genres qui ont été nommés Poiretia et Turpinia, et discussion sur ceux qui doivent conseiver ce nom. Journal de botanique, appliquée à Yagriculture, à la pharmacie, à la médecine et aux arts, tome [I], pp. 228-229, Paris, Mai, 1813.

Suggests the generic name Schmaltzia instead of Turpinia, a proposed segregation from Rhus.

40 [Deisvaux, N. A.] Observations du Rédacteur. Desvaux's Journal de Botanique, tome quatrième, pp. 176-177 [276277], Paris, 1814.

An editorial commenting on some of Rafinesque's publications.

41 [Desvaux, N. A.] Sur les Ouvrages de M. RafinesqueSchmaltz. Desvaux's Journal de Botanique, tome quatrième, p. 268, Paris, 1814.

42 Eaton, Amos. A manual of botany for the northern and middle states, p. 6, Albany, 1818.

42a ElliotT, Stephen. A sketch of the botany of SouthCarolina and Georgia, preface, p. vi, Charleston, 1824.

43 Fairchild, Herman Le Roy. A history of the New York 
Academy of Sciences, formerly the Lyceum of Natural History, New York, 1887.

References of greater or lesser length to Rafinesque occur on pages 4 , $10,11,12,21,22,26,98,99$, and 102 .

44 [Featherstonhaugh, G. W.] Professor Rafinesque. The Monthly American Journal of Geology and Natural Science, vol. I, no. 7, pp. 328-329, January, 1832.

A short article mainly on Rafinesque's pamphlet entitled: "A Continuation of a Monograph of the Bivalve Shells of the River Ohio and Other Rivers of the Western States," and written in a satirical vein.

45 [Featherstonhaugh, G. W. Review of] Monograph of the Bivalve Shells of the River Ohio.-Translated from the French of Professor Rafinesque, by C. A. Paulson, Esq. The Monthly American Journal of Geology and Natural Science, vol. I, no. 8, pp. 372-375, February, 1832.

46 Ferussac, A. E. J. P. J. F. d'Audebard de. Observations sur les Naiades. Magazine de Zoologie, numbers 59 and 60, p. 13, 1835.

The writer has not examined this work.

47 Fitzpatrick, T. J. Additions to the Bibliography of Rafinesque. The Iowa Naturalist, vol. I, no. 1, pp. 10-21, Iowa City, January, 1905.

48 Fitzpatrick, T. J. Additions to the Bibliography of Rafinesque, II. The Iowa Naturalist, vol. I, no. 2, pp. 38-39, Iowa City, April, 1905.

49 Fitzpatrick, T. J.: | Additions | to the | Bibliography | of | Rafinesque | by T J Fitzpatrick | Iowa City, Iowa | February 1905

Paper, octavo in size, folio in fold, pp. [1-2], 3-14.

50 Fitzpatrick, T. J. Constantine Samuel Rafinesque - A Sketch. Annals of Iowa, vol. vir, no. 3, pp. 196-224, Des Moines, October, 1905.

51 Fox, Wm. J. Rafinesque's Western Minerva, or American Annals of Knowledge and Literature. Science, new series, vol. xII, no. 293, pp. 211-215, August 10, 1900.

The writer gives a description of the Western Minerva, as well as a commentary on the contents, a copy of which is preserved in the Library of the Academy of Natural Sciences of Philadelphia. 
52 Fox, William J. Two unknown works of Rafinesque. Science, new series, vol. xiv, no. 352, p. 498, September 27, 1901.

Mentions Florula Lexingtoniensis and American Florist.

53 Fox, William J. A correction. Science, new series, vol. XIV, no. 355, p. 617, October 18, 1901. Short.

Concludes that the Florula Lexingtoniensis was the work of C. W.

54 Garman, S. The generic name of the Pastinacas or "Sting-rays." Proceedings of the United States National Museum, vol. viII, 1885, pp. 221-224, 1886.

55 [Gerard, W. R.] Additions to the U. S. Phalloidei. Bulletin of the Torrey Botanical Club, vol. vir, no. 3, pp. 29-30, New York, March, 1880.

56 G.[ERARD], W. R. Reliquiæ Rafinesquianæ. Bulletin of the Torrey Botanical Club, vol. XII, no. 4, pp. 37-38, New York, April, 1885.

57 GILL, THEODORE. On the relations and nomenclature of Stizostedion or Lucioperca. Proceedings of the United States National Museum, vol. xviI, 1894, pp. 123-128, 1895.

58 Gill, ThFodore. William Swainson and his times. The Osprey, vol. Iv, no. 7, pp. 104-108, Washington, March, 1900.

59 Girard, Charles. Researches upon the Cyprinoid Fishes inhabiting the fresh-waters of the United States of America west of the Mississippi valley, from specimens in the Museum of the Smithsonian Institution. Proceedings of the Academy of Natural Sciences of Philadelphia, vol. viII, pp. 165-213, Philadelphia, September, 1856.

This article restores many of Rafinesque's genera and on page 167 speaks of Rafinesque and his Ichthyologia Ohiensis.

60 Goode, G. Brown. The Beginnings of American Science. The Third Century. In Annual Presidential Address Delivered at the Seventh Anniversary Meeting of the Biological Society of Washington, January 22, 1887. Proceedings of the Biological Society of Washington, vol. Iv, pp. 25-26, 37 and 66, Washington, 1888.

61 Goode, G. Brown. [Review of] The Life and Writings of Constantine Samuel Rafinesque, *** by Richard Ellsworth 
Call. Science, new series, volume I, no. 14, pp. 384-387, April 5, 1895.

This is mainly a sketch of the life of Rafinesque.

62 Goode, George Brown. [A sketch of Rafinesque.] In The Beginnings of Natural History in America. Report of the Smithsonian Institution, 1897 - U. S. National Museum, part II, p. 420, Washington, 1901.

On page 428 there will be found Rafinesque's views on evolution. References to Rafinesque and his work occur on pages 92 note, 428, 438, 442, 447 , and 450 .

63 G. [RAY], A.[SA]. Notice of the Botanical Writings of the late C. S. Rafinesque. The American Journal of Science and Arts, 1st series, vol. xL, no. 2, pp. 221-241, 1841.

64 GreEne, Edward L. The North American Neilliæ. Pittonia; A Series of Botanical Papers, vol. II, part 7, pp. [25]-31, Berkeley, December, 1889.

65 Greene, Edward L. Reprint of Fraser's Catalogue. Pittonia ; A Series of Botahical Papers, vol. II, part 9, p. 115, Berkeley, December, 1890.

66 Greene, Edward L. Some Genera of Rafinesque. Pittonia; A Series of Botanical Papers, vol. II, part 9, pp. [120]-133, Berkeley, December, 1890.

67 Greene, Edward L. On Some North American Ranunculi. Pittonia; A Series of Botanical Papers, vol. II, part 8, pp. [58]-65, Berkeley, May, 1890.

68 Greene, Edward L. Some Neglected Priorities in Generic Nomenclature. Pittonia; A Series of Botanical Papers, vol. II, part 10, pp. 173-184, Berkeley, July - September, 1891.

69 GrEENe, Edward L. Against the Using of Revertible Generic Names. Pittonia; A Series of Botanical Papers, vol. II, part 10, pp. [185]-195, Berkeley, July - September, 1891.

70 Greene, Edward L. On Certain Spiræaceæ. Pittonia; A Series of Botanical Papers, vol. II, part 11, pp. [219]-222, Berkeley, May - August, 1892.

71 Greene, Edward L. Corrections in Nomenclature - I. Pittonia ; A Series of Botanical Papers, vol. III, part 16, pp. [186]188, Washington, April - July, 1897. 
72 Greene, Edward L. Corrections in Nomenclature - II. Pittonia ; A Series of Botanical Papers, vol. III, part 17, pp. [207]212, Washington, September - December, 1897.

72a Greene, Edward L. A new name for Bayberries. Leaflets, vol. 2, pp. 103-104, Washington, July, 1910.

73 Haldemann, S. S. Notice of the Zoological Writings of the Late C. S. Rafinesque. The American Journal of Science, 1st Series, vol. XLII, no. 2, pp. 280-291, January - March, 1842.

74 Harlan, Richard. Fauna Americana: being a description of the mammiferous animals inhabiting North America, Philadelphia, 1825.

References to Rafinesque are in the introduction, p. vii, and in the appendix, pp. 303-308.

75 Harshberger, John W. Constantine Samuel Rafinesque [Schmaltz]. The Botanists of Philadelphia and Their Work, pp. 144-148, Philadelphia, 1899.

In a footnote the article is credited to G. H. Hicks. In fact it is almost entirely a verbatim reprint of the article by Mr. Hicks published in the Asa Gray Bulletin, January, 1896.

Other references in this volume are: pp. 4, 13, 66, 175-176, and 230.

76 H. H. Letter to Editor of the Philadelphia Ledger concerning Rafinesque, dated 5th May, 1877.

77 H. H. [A short sketch of the life of Rafinesque.] The American Naturalist, vol. xI, no. 9, pp. 574-575, September, 1877.

An article quoted from the Philadelphia Ledger Supplement, May 5, 1877. There are very few correct statements in the article.

78 Haven, Samuel F. Archaeology of the United States, or sketches, historical and bibliographical, of the progress of information and opinion respecting vestiges of antiquity in the United States. In Smithsonian Contributions to Knowledge, volume viII, article I, pp. 39-41, Washington, 1856.

79 Hicks, G. H. Biographical series, no. III. Rafinesque. The Asa Gray Bulletin, vol. Iv, no. 1, pp. 6-8, January, 1896.

79a Tidestrom, Ivar. Notes on Peltandra, Rafinesque. Rhodora, vol. 12, no. 135, pp. 47-50, March, 1910.

80 James, Jos: T. Letter from Dr. Torrey to Amos Eaton 
The Botanical Gazette, vol. viII, no. 9, pp. [289]-291, September, 1883.

In this letter Doctor Torrey speaks of Rafinesque: "He is the best naturalist I am acquainted with, but he is too fond of novelty. He finds too many new things. All is new! new !"

81 Jordan, David S. Concerning the fishes of the Ichthyologia Ohiensis. Bulletin of the Buffalo Society of Natural Sciences, vol. III, no. 3, pp. 91-97, Buffalo, 1876.

The title page to the volume gives the date 1877 but the part containing the article was issued in 1876.

82 Jordan, David S. Contributions to North American Ichthyology, no. 1. Review of Rafinesque's Memoirs on North American Fishes. Bulletin of the United States National Museum, no. IX, pp. 1-53, Washington, 1877.

83 Jordan, David L. [S.] Report on the Fishes of Ohio. Report of the Geological Survey of Ohio, vol. Iv, pp. 737-741, Columbus, 1882.

84 Jordan, David S. and Gilbert, Charles H. On the synonymy of the genus Bothus Rafinesque. Proceedings of the United States National Museum, vol. v, 1882, pp. 576-577, Washington, 1883.

85 Jordan, David S. and Gilbert, Charless H. Notes on the nomenclature of certain North American fishes. Proceedings of the United States National Museum, vol. vi, 1883, p. 110, Washington, 1884.

86 Jordan, David S. Note on the scientific name of the yellow perch, the striped bass, and other North American fishes. Proceedings of the United States National Museum, vol. vin, 1885, pp. 72-73, Washington, 1886.

87 Jordan, David S. Identification of the species of Cyprinidæe and Catostomidæ, described by Dr. Charles Girard, in the Proceedings of the Academy of Natural Sciences of Philadelphia for 1856. Proceedings of the United States National Museum, vol. viII, 1885, pp. 118-127, Washington, 1886.

88. Jordan, David STARr. [A sketch of Constantine Samuel] Rafinesque. The Popular Science Monthly, vol. xxix, no. 2, pp. 212-221, June, 1886. 
89 Jordan, David Starr. An eccentric naturalist. In Science Sketches, pp. 143-159, Chicago, 1888.

90 Jordan, David S. Note on the "Analyse de la Nature" of Rafinesque. Proceedings of the United States National Museum, vol. x, 1887, pp. 480-481, Washington, 1888.

91 Jordan, David Starr. On the Generic Name of the Tunny. Proceedings of the Academy of Natural Sciences of Philadelphia, 1888, p. 180, Philadelphia, 1889.

Speaks of Rafinesque's "Analyse de la Nature" as worthless.

92 Jordan, D. S. Rafinesque, Constantine Samuel. Johnson's Universal Cyclopædia; a new edition, vol. vi, p. 895, New York, 1895, also 1897.

Gives erroneously the dates of birth and death.

93 KeEp, Josiah. Eminent Naturalists.-II. Rafinesque.-The West American Scientist, vol. II, no. 19, pp. 99-102, October, 1886.

94 KirTLAND, JARED P. Descriptions of four new species of fishes. Boston Journal of Natural History, vol. III, nos. 1-2, pp. 273-279, January, 1840.

95 KirTland, Jared P. Descriptions of the fishes of the Ohio river and its tributaries. Boston Journal of Natural History, vol. III, no. 3, pp. 338-352, July, 1840 ; no. 4, pp. 469-482, November, 1840 ; vol. 4, no. 1, pp. 16-26, January, 1842; no. 2, pp. 231-240, September, 1842 ; no. 3, pp. 303-308, April, 1843 ; vol. 5, no. 1, pp. 21-32, January, 1845.

96 KirTLAND, JarEd P. Descriptions of the fishes of Lake Erie, the Ohio river, and their tributaries. Boston Journal of Natural History, vol. 5, no. 2, pp. 265-276, October, 1845 ; no. 3 , pp. 330-344, June, 1846.

97 LEA, IsAac. Rectification of Mr. T. A. Conrad's "Synopsis of the Family of Naïades of North America," published in the "Proceedings of the Academy of Natural Sciences of Philadelphia, February, 1853." Proceedings of the Academy of Natural Sciences of Philadelphia, vol. viI, pp. 236-249, Philadelphia, December, 1854.

A controversial article in which the writer commends his own labors and decries the efforts of Rafinesque. See number 30 .

98 LEA, IsaAc. A Synopsis of the Family Unionidx, third 
edition, p. xx, 1852; also fourth edition, pp. xxviii-xxx, 91-92, Philadelphia, 1870.

99 LE Conte, John. Description of a new species of the Pacane Nut. Proceedings of the Academy of Natural Sciences of Philadelphia, vol. vi, p. 402, Philadelphia, September, 1853.

100 LE CONTE, John. An enumeration of the Vines of North America. Proceedings of the Academy of Natural Sciences of Philadelphia, vol. vi, pp. 269-274, Philadelphia, February, 1853.

Gives a short account of Rafinesque's work on the genus Vitis on page 270 , with occasional notes in the article.

101 LEIDY, JosEPH. The Extinct Mammalian Fauna of Dakota and Nebraska, including an account of some allied forms from other localities together with a synopsis of the mammalian remains of North America, p. 376. In Journal of The Academy of Natural Sciences of Philadelphia, vol. vir.-Second series, 1869.

Speaks of Rafinesque's proposed three species founded upon remains supposedly those of the Virginia deer.

102 [LeggetT, William H.] Elias Durand. Bulletin of the Torrey Botanical Club, vol. Iv, no. 10, pp. [45]-47, New York, October, 1873.

103 L.[EGGETT], W. H. Rafinesque's Lechea. Bulletin of the Torrey Botanical Club, vol. vi, nos. 43-44, pp. 246-252, New York, July \& August, 1878.

104 LEWIS, Alvin FAYETTE. History of Higher Education in Kentucky, p. 59, Washington, 1899.

105 Mathews, Albert. Correspondence of Rafinesque and Cutler. Science, new series, vol. xv, no. 389, p. 951, June 3, 1902.

Mentions a letter of Rafinesque to Cutler, dated, Palermo, January 28, 1807, to be found in Cutler's "Life, Journals and Correspondence," 1888, II, 311-314.

106 [Menhan, Thomas.] Rafinesque. The Gardener's Monthly, old series, vol. x, new series, vol. I, no. 8, p. 253, August, 1868.

A short sketch, mainly a quotation from the Philadelphia Sunday Dispatch, date of which is not given.

107 Menhan, Thomas. C. S. Rafinesque. The Botanical Gazette, vol. viII, no. 2, pp. 177-178, February, 1883.

108 MEEhan, Thomas. Rafinesque. Career of a naturalist 
of more than ordinary brilliancy. A Man who, in His Day, was Misunderstood and Derided as a Madman, at Length Honored by Men of Science. Philadelphia Public Ledger, February 19, 1891.

109 [Mitchill, Samues, L. Review of] Florula Ludoviciana; or a Flora of the State of Louisiana. Translated, revised, and improved, from the French of C. C. Robin, by C. S. Rafinesque. The American Monthly Magazine and Critical Review, vol. II, no. v, p. 366, March, 1818.

110 Montgomery, Thomas L. Correspondence of C. S. Rafinesque and Professor Wm. Wagner. Science, new series, vol. xi, no. 273, pp. 449-451, March 23, 1900.

111 PECK, W. D. [Rafinesque and the canvas-back duck.] In Life, Journals and Correspondence of Rev. Manasseh Cutler, vol. II, p. 325, Cincinnati, 1888.

In letter to Rev. Cutler, dated July 1, 1805.

112 PETER, RoberT. Transylvania University, its origin, rise, decline, and fall, Louisville, 1896.

Refers incidentally to Rafinesque on pages 97 and 125 .

113 Peter, RoberT. [Sketch of] Constantine Samuel Rafinesque. In the History of the Medical Department of Transylvania University, pp. 35-40, Louisville, 1905.

114 Poulson, C. A. A monograph of the fluviatile bivalve shells of the river Ohio, translated from the French of C. S. Rafinesque, Philadelphia, 1832 ; see pp. [iii], iv-vi.

See Bibliography, number 608.

115 Rafinesque, C. S. A Life of Travels and Researches in North America and South Europe, or Outlines of The Life, Travels and Researches of C. S. Rafinesque, Philadelphia, 1836.

See Bibliography, number 863.

115a Richmond, Charles W. A reprint of the ornithological writings of .C. S. Rafinesque. The Auk, vol. 36, no. 1, pp. 37-55, January, 1909; no. 3, pp. 248-262, July, 1909.

116 [Rothrock, Joseph T.] The Biological School [in the University of Pennsylvania]. In Benjamin Franklin and the University of Pennsylvania, by F. N. Thorpe, Washington, 1893.

On page 328 the statement is made that Mr. C. S. Rafinesque and Dr. William P. C. Barton offered themselves as candidates for the professor- 
ship of natural history and botany, February 6,1816. On page 329 it is stated that in December, 1816, Doctor Barton was appointed professor of botany.

117 [SARgent, C. S.] Rafinesque. Garden and Forest, vol. IV, no. 162, p. 146, April 1, 1891.

118 [Silliman, Benjamin. A note on the Analysis of Nature]. The American Journal of Science, vol. 1, no. 4, p. 435, 1819.

119 [Siliman, Benjumin.] C. S. Rafinesque, Esq. The American Journal of Science, vol. 1, no. 3, p. 311, 1819.

This item speaks of Rafinesque's scientific labors in the west and mentions his proposed publication: Travels and Discoveries in the West.

120 [Silliman, Benjamin. An observation on the character of Rafinesque.] The American Journal of Science and Arts, vol. XL, no. 2, p. 237, January - March, 1841.

A footnote.

121 Simpson, Henry. [Sketch of] C. S. Rafinesque. In The Lives of Eminent Philadelphians, pp. 823-824, Philadelphia, 1859.

Gives the year of birth as 1784 and the date of death as September 18, 1842 , both erroneous.

122 Small, John K. The Genus Tradescantia in the Southern States. Bulletin of the Torrey Botanical Club, vol. 24, no. 5, pp. 228-236, May, 1897.

123 SquiER, E. G. and Davis, E. H. Ancient Monuments of the Mississippi Valley. Smithsonian Contributions to Knowledge, vol. 1, Washington, 1848.

Speaks of Rafinesque and his archaeological work on p. xxxvi. Gives excerpts from his manuscripts on pp. 26, 31, 35, 36, 93, 108, and 175 .

The material was taken from Rafinesque's manuscripts then in the possession of Mr. Brantz Mayer of Baltimore.

124 ST. John, Mrs. Horace. Audubon, the Naturalist of the New World, his adventures and discoveries, pp. 51-58, Boston, 1864.

124a STEJNEGER, L. Rafinesque on evolution. Science, new series, vol. 23, pp. 785-786, May 18, 1906.

125 Swainson, Wilitiam. On the Natural History and Clas- 
sification of Fishes, Amphibians and Reptiles. Lardner's Cabinet Cyclopedia, vol. I, pp. 60-63, London, 1838.

Contains an appreciation of Rafinesque and of his work on the fishes of Sicily.

126 Thomas, Joserph. Universal Pronouncing Dictionary of Biography and Mythology, new edition, p. 2022, Philadelphia, 1893.

Gives erroneously the date of death.

127 Thorpe, Francis Newton. Benjamin Franklin and the University of Pennsylvania, p. 328, Washington, 1893.

Mention of Rafinesque's application for a professorship in the University of Pennsylvania in the article on "the biological school," by J. T. Rothrock, in Bureau of Education, Circular of Information, no. 2, 1892.

128 [Tryon, George W.] A Sketch of the History of Conchology in the United States. The American Journal of Science and Arts, 2d series, vol. xxxiII, no. 98, pp. 161-180, March, 1862.

Pages $163-164$ refer to C. S. Rafinesque.

129 Underwood, Lucien Marcus. Moulds, Mildews and Mushrooms, New York, 1899.

The author on page 160 mentions with comment the efforts of Rafinesque in the study of the fungi.

130 Underwood, Lucien Marcus. The progress of our Knowledge of the flora of North America. The Popular Science Monthly, vol. Lxx, pp. 497-517, June, 1907.

She statements concerning Rafinesque are on pp. 511-512.

131 Venable, W. H. [Sketch of Rafinesque.] In Beginnings of Literary Culture in the Ohio Valley, pp. 167-168, Cincinnati, 1891.

Also Rafinesque is mentioned on pages 62, 67-68, and 169.

132 WiLlis, O. R. [A note.] Bulletin of the Torrey Botanical Club, vol. XII, no. 12, p. 136, December, 1885.

133 Wilson, J. G. and Fiske, John. Constantine Samuel Rafinesque. Appleton's Cyclopædia of American Biography, vol. v. p. 159, New York, 1898.

134 Youmans, William Jay. Constantine Samuel Rafinesque, 1783-1840. In Pioneers of Science in America, Sketches 
of their Lives and Scientific Work, reprinted with additions from the Popular Science Monthly, edited and revised by William Jay Youmans, pp. 182-195, New York, 1896.

Gives portrait. The article is a revision of the sketch by David Starr Jordan which appeared in the Popular Science Monthly for June, 1886. 


\section{PORTRAITS OF RAFINESQUE}

All the portraits of Rafinesque known to the writer are, with one exception, reproductions in some form of the one given by Rafinesque as a frontispiece to one of his early works, the Analyse de la nature published at Palermo in 1815. The exception is the portrait facing page 68 of Call's Life and Writings of Rafinesque. This one is a reproduction of a painting by Jouett which is in the possession of the State Historical Society of Wisconsin. Some doubt has been expressed as to its genuineness.

The usual portrait with the attendant background has been characterized as follows: "The picture is a very interesting one in that it so well shows some of the peculiar features thus early developing in the mental life of the naturalist. The wide range which his studies and his activities already had assumed is indicated by the ornamentation of the plate. Modelling his work after Linnæus he sought to establish it on probity and philosophy. They constitute the foundation stones of the character which he hoped to build. The birds of the air, the animals and plants of the fields, the fishes and mollusks of the waters, are all included in the illustration as reminders of the diverse directions in which his energies had been expended. He was a merchant, and the son of a merchant; he had been a traveller; and so, in the offing, there appears a ship under full sail. A happy conceit this, if we only pardon the bit of personal vanity which it implies.'

Some of the reproductions omit the background and sometimes also the oval border with its legend. This portrait according to the legend at the lower left cor-

${ }^{51}$ Call, Life and Writings of Rafinesque, p. 68. 
ner was executed in I8Io although not published until five years later. Consequently it represents Rafinesque as he appeared in his twenty-seventh year.

Analyse de la nature, Palerme, 1815, frontispiece.

See Bibliography, no. 235.

Potter's American Monthly, vol. vi, no. 50, p. 97, Philadelphia, 1876.

The Popular Science Monthly, vol. xL, no. 6, April, 1892, fácing p. 721, frontispiece to the number.

Ichthyologia Ohiensis, reprint by R. E. Call, Cleveland, 1899, frontispiece.

Life and Writings of Rafinesque, by R. E. Call, Louisville, 1895, frontispiece, also another facing p. 68.

Pioneers of Science in America, edited and revised by William Jay Youmans, New York, 1896.

Report of the Smithsonian Institution, 1897 - LT. S. National Museum, part II, facing p. 370, Washington, 1901

Annals of Iowa, third series, vol. vir, no. 3, facing p. 196, Des Moines, October, 1905. 


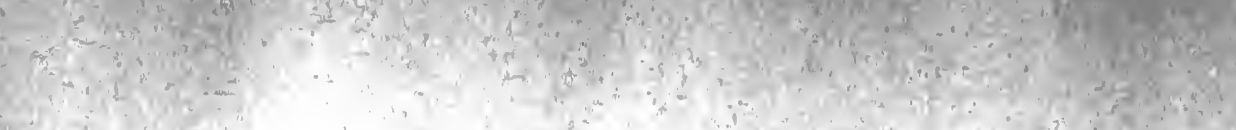
W.

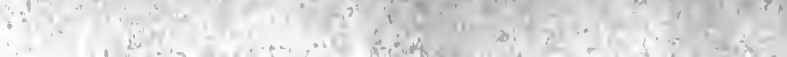

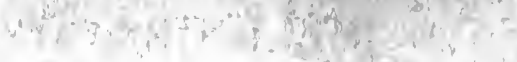

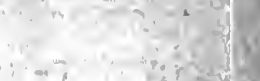

$\cdots+3 y$

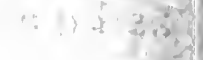

$+1$

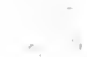

is

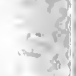

4.

18

3

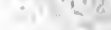

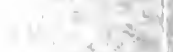

$(-2)$

$-1$

a

$-8$

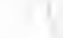

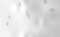

$\therefore$ 


(3) 

1.9. $6 x^{2}+2+2$

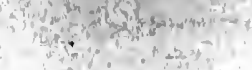

2
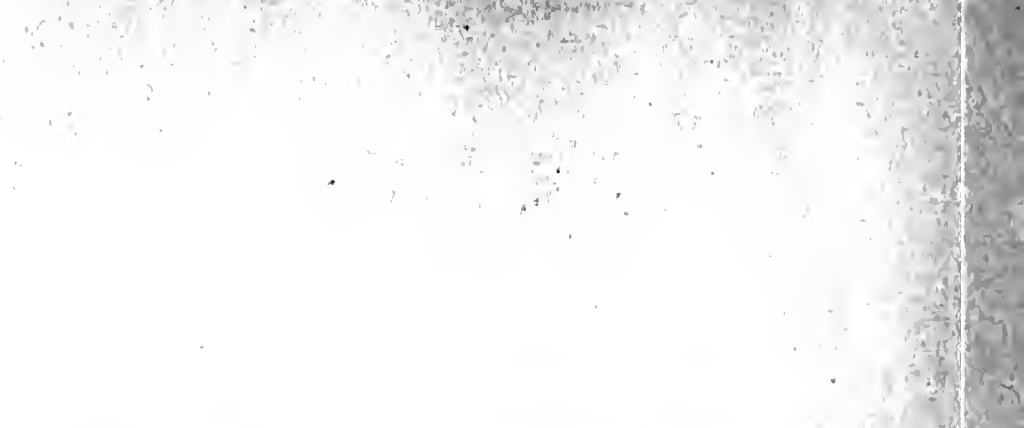

i, 5
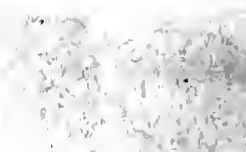

th

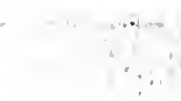

$(4)$
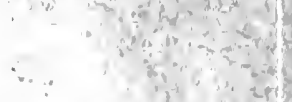

$3 x+\frac{2}{2}$ oit in 2 की म8

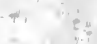




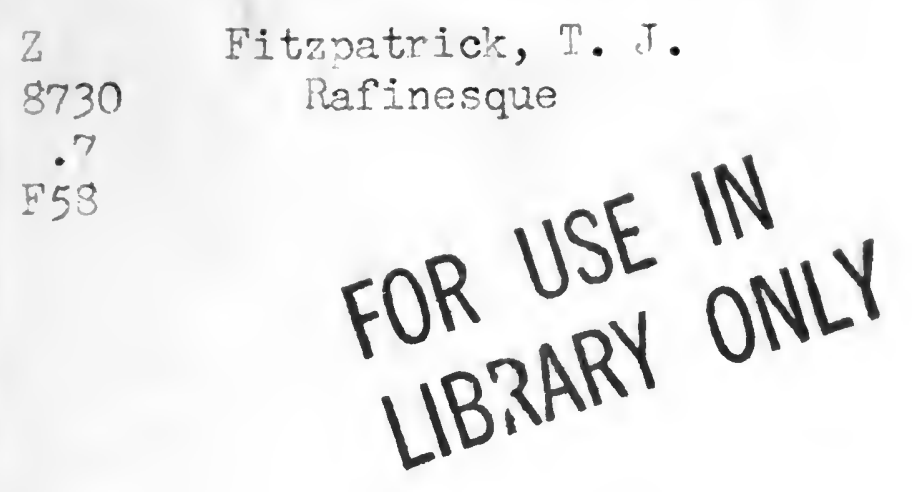

\author{
PLEASE DO NOT REMOVE \\ CARDS OR SLIPS FROM THIS POCKET
}

UNIVERSITY OF TORONTO LIBRARY 
